$\operatorname{Argonne} \underset{\bigotimes}{\bigotimes}$

\title{
Final Work Plan: Phase I Investigation at Bladen, Nebraska
}

\section{Environmental Science Division}




\begin{abstract}
About Argonne National Laboratory
Argonne is a U.S. Department of Energy laboratory managed by UChicago Argonne, LLC under contract DE-AC02-06CH11357. The Laboratory's main facility is outside Chicago, at 9700 South Cass Avenue, Argonne, Illinois 60439. For information about Argonne and its pioneering science and technology programs, see www.anl.gov.
\end{abstract}

\title{
DOCUMENT AVAILABILITY
}

Online Access: U.S. Department of Energy (DOE) reports produced after 1991 and a growing number of pre-1991 documents are available free via DOE's SciTech Connect (http://www.osti.gov/scitech/)

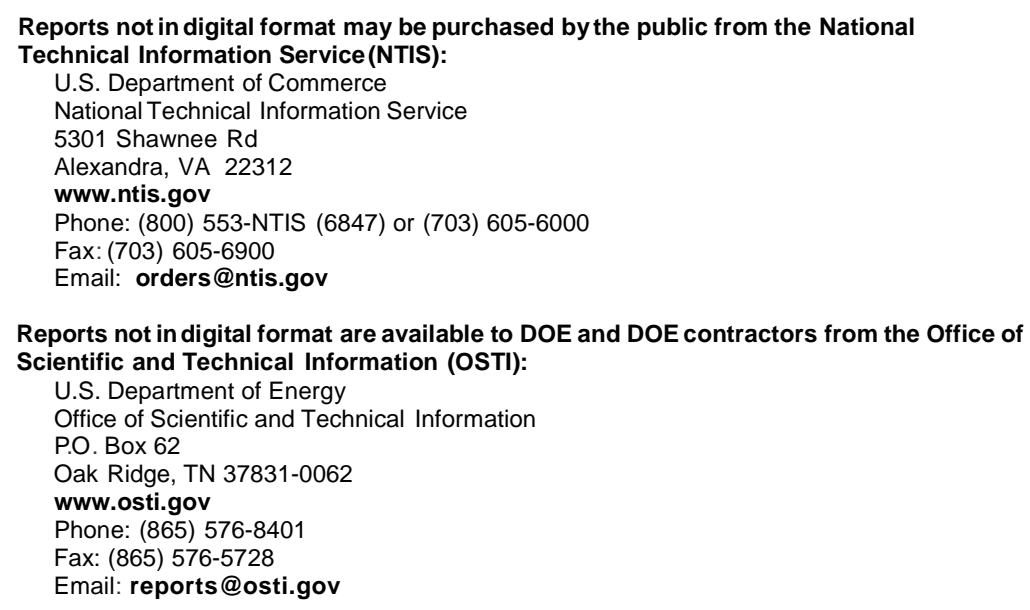

\section{Disclaimer}

This report was prepared as an account of work sponsored by an agency of the United States Government. Reference herein to any specific commercial product, process, or service by trade name, trademark, manufacturer, or otherwise, does not necessarily constitute or imply its endorsement, recommendation, or favoring by the United States Government or any agency thereof. The views and opinions of document authors expressed herein do not necessarily state or reflect those of the United States Government or any agency thereof, Argonne National Laboratory, or UChicago Argonne, LLC. 


\section{Final Work Plan: Phase I Investigation at Bladen, Nebraska}

by

Applied Geosciences and Environmental Management Section Environmental Science Division, Argonne National Laboratory

July 2014

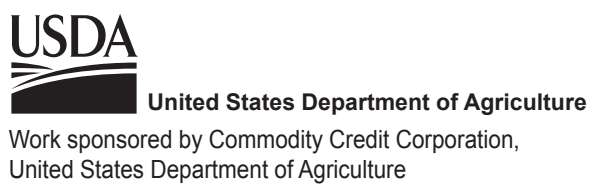




\section{Contents}

Notation.

1 Introduction

2 Background and Previous Studies

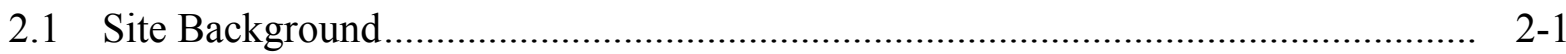

2.1.1 Area Description ......................................................................... 2-1

2.1.2 Bladen Public Water Supply ........................................................................ 2-1

2.1.3 Wellhead Protection Area for the Public Water Supply Wells...................... 2-3

2.2 Previous Investigations ....................................................................................... 2-3

2.2.1 Investigations of Leaking Underground Storage Tank Sites ........................ 2- 2-4

2.2.2 Woodward Clyde Private Well Sampling for the CCC/USDA in 1997 ........ 2-6

2.2.3 NDEQ Pre-CERCLIS Site Screening Assessment in 2012 ........................ 2-6

2.2.4 Argonne Private Well SMPling for the CCC/USDA in September 2012 ..... 2-7

2.3 Geologic and Hydrogeologic Setting .................................................................. 2-. 2-7

2.3.1 Regional Geology and Hydrogeology .................................................... 2-8

2.3.2 Local Geology and Hydrogeology ............................................................. 2-10

2.4 Identification of Potential Contaminant Source Areas …………............................. 2-12

2.4.1 Former CCC/USDA Grain Storage Facility and Subsequent Grain Operations.................................................................................... 2-13

2.4.2 Private Grain Operation Facility along the Railroad Right-of-Way.............. 2-14

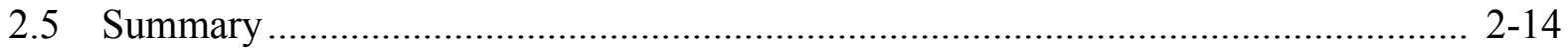

3 Proposed Technical Program for the Phase I Investigation .............................................. 3-1

3.1 Technical Objectives of the Phase I Investigation .................................................... 3-1

3.2 Phase I Investigation Tasks............................................................................ 3-2

3.2.1 Task 1: Determine the Presence of a Potential Soil Source of Carbon Tetrachloride and Its Daughter Products in the Vadose Zone beneath the Former CCC/USDA Facility

3.2.2 Task 2: Characterize the Site-Specific Geology and Hydrogeology at the Former CCC/USDA Facility.

3.2.3 Task 3: Delineate the Distribution of Carbon Tetrachloride and Its Daughter Products in Groundwater at the Former CCC/USDA Facility.......

3.2.4 Task 4: Obtain Information on the Groundwater Flow Patterns That Affect Potential Off-Site Contaminant Migration from the Former CCC/USDA Facility

4 Investigative Methods.

4.1 Methods for Shallow Soil Sampling and Analysis .................................................. 4-2

4.2 Methods for Soil Gas Sampling and Analysis ...................................................... 4-2

4.3 Methods for Deeper Soil Sampling and Analysis.................................................... 4-3 


\section{Contents (Cont.)}

4.4 Methods for Deep Boring and Logging ...........................................................

4.5 Methods for Groundwater Sampling and Analysis.............................................. 4-4

4.5.1 Groundwater Sampling with the Cone Penetrometer ............................... 4-4

4.5.2 Groundwater Sampling with the Drilling Rig......................................... 4-5

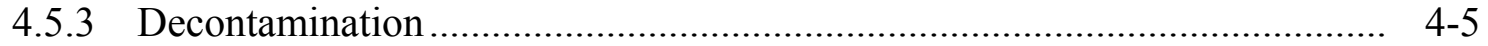

4.5.4 Sample Preservation and Analysis ........................................................ 4-5

4.6 Methods for Installing Monitoring Wells and Abandoning Boreholes ................... 4-6

4.7 Methods for Water Level Monitoring................................................................. 4-6

4.8 Methods for Handling and Disposal of Investigation-Derived Waste..................... 4-7

4.9 Quality Assurance/Quality Control for Sampling and Analysis............................. 4-8

4.9.1 Field Quality Assurance/Quality Control for Sampling and Analysis.......... 4-8

4.9.2 Laboratory Quality Assurance/Quality Control for Sampling and Analysis.................................................................................. 4-11

4.9.3 Quality Assurance Records ............................................................... 4-13

4.9.4 Analytical Data Reduction, Validation, and Reporting .............................. 4-14

4.10 Field Investigation Schedule .......................................................................... 4-15

5 Community Relations Plan ............................................................................. $5-1$

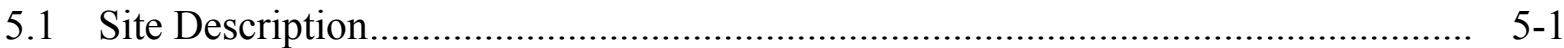

5.2 Community Background ........................................................................ $5-1$

5.2.1 History of Community Involvement Associated with

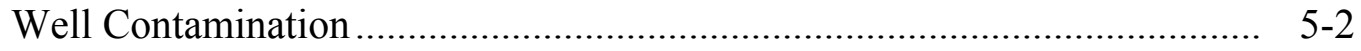

5.2.2 Key Community Concerns........................................................... $5-2$

5.3 Community Relations Objectives .............................................................. $5-2$

5.4 Timing of Community Relations Activities...................................................... $5-3$

5.4.1 Activities before Field Work Begins ............................................... $5-3$

5.4.2 Activities during Field Work .............................................................. $5-4$

5.4.3 Activities upon Completion of Field Work Activities ................................ 5-5

5.5 Contact List of Key Officials ..................................................................... $5-5$

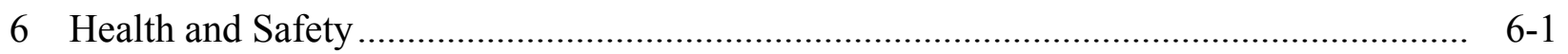

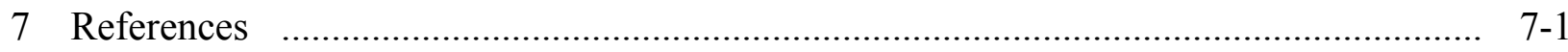

Appendix A: Information on Public Water Supply Wells ........................................... A-1

Appendix B: Nebraska Wellhead Protection Area Map for the Bladen Public Water Supply System and Data Used to Construct the Map.

Appendix C: Geologic Logs and Well Information for Private and Public Water Wells and State Test Holes Used in Construction of Geologic Cross Sections A-A', B-B', and C-C' 


\section{Contents (Cont.)}

Appendix D: Property Records for the Former CCC/USDA Facility

D-1

\section{Tables}

2.1 Analytical results for groundwater samples collected from the public water supply system at Bladen.

2.2 Analytical results for groundwater samples collected from private wells in the vicinity of Bladen.

2.3 Documented transactions and activities for the former CCC/USDA property at Bladen, Nebraska

3.1 Summary of Phase I investigation tasks $3-10$

6.1 Emergency information for the investigation at Bladen, Nebraska

\section{Figures}

1.1 Location of Bladen, Nebraska.

1.2 Locations of the former CCC/USDA facility, nearby agricultural business facilities, leaking underground storage tank sites, and public water supply wells ....

2.1 Historical carbon tetrachloride concentrations in groundwater samples collected from private wells by Woodward Clyde for the CCC/USDA in November 1997 and by Argonne for the CCC/USDA in July 2012

2.2 Locations of water wells within $1 \mathrm{mi}$ of the former CCC/USDA facility that have been registered with the state and nearby state geologic test holes, with the location of geologic cross section A- $\mathrm{A}^{\prime}$

2.3 Locations of geologic cross sections B-B' and C-C' and the selected water wells used to construct the cross sections

2.4 West-to-east hydrogeologic cross section A-A', illustrating regional stratigraphic relationships and water levels

2.5 North-to-south geologic cross section B-B', illustrating local stratigraphic relationships and water levels at Bladen..... 


\section{Figures (Cont.)}

2.6 West-to-east geologic cross section C-C', illustrating local stratigraphic relationships and water levels at Bladen

2.7 Historical and recent aerial photographs $(1956,1963,1969,2012)$, showing grain storage structures on the former CCC/USDA grain storage facility near the southern edge of Bladen and private grain operation facilities along the railroad right-of-way

2.8 Historical aerial photographs (1993 and 1999), showing grain storage structures on the former CCC/USDA grain storage facility near the southern edge of Bladen and private grain operation facilities along the railroad right-of-way

2.9 Locations and ownership of properties related to grain storage operations at Bladen, interpreted from property records, local community information, and aerial photographs

3.1 Proposed shallow soil sampling locations on the former CCC/USDA property

3.2 Proposed groundwater sampling locations on the former CCC/USDA

6.1 Emergency route from the Bladen site to the Hastings Hospital 


\section{Notation}

AGEM Applied Geosciences and Environmental Management

AMSL above mean sea level

BGL below ground level

BTEX benzene, toluene, ethylbenzene, and xylene

${ }^{\circ} \mathrm{C} \quad$ degree(s) Celsius

CCC Commodity Credit Corporation

CERCLA Comprehensive Environmental Response, Compensation, and Liability Act

CERCLIS CERCLA Information System

CLP Contract Laboratory Program

$\mathrm{cm} \quad$ centimeter(s)

CPT cone penetrometer

EPA U.S. Environmental Protection Agency

$\mathrm{ft} \quad$ foot (feet)

gal gallon(s)

GC-MS gas chromatography-mass spectrometry

gpm gallon(s) per minute

GSI Geotechnical Services, Inc.

h hour(s)

I.D. inner diameter

IDW investigation-derived waste

in. $\quad$ inch(es)

L liter(s)

LUST leaking underground storage tank

MCL maximum contaminant level

$\mu \mathrm{g} / \mathrm{L} \quad$ microgram(s) per liter

$\mathrm{mg} / \mathrm{L} \quad$ milligram(s) per liter

mi mile(s)

$\mathrm{mL} \quad$ milliliter(s)

NAIP National Agriculture Imagery Program

NDEQ Nebraska Department of Environmental Quality

NDHHS Nebraska Department of Health and Human Services

NRD Natural Resources District

PRT Post-Run Tubing

PVC polyvinyl chloride

PWS public water supply

QA/QC quality assurance/quality control

TCLP toxicity characteristic leaching procedure

TRPH total recoverable petroleum hydrocarbon

USDA U.S. Department of Agriculture

USGS U.S. Geological Survey 
Bladen, Nebraska, Phase I Work Plan

Version 01, 06/03/14

VOC volatile organic compound

WhAEM Wellhead Analytic Element Model

WHP Wellhead Protection (Program)

WHPA wellhead protection area

yr

year(s) 


\section{Final Work Plan: Phase I Investigation at Bladen, Nebraska}

\section{Introduction}

The village of Bladen is a town of population approximately 237 in the northwest part of Webster County, Nebraska (Figure 1.1), $30 \mathrm{mi}$ southwest of Hastings and $140 \mathrm{mi}$ southwest of Lincoln, Nebraska. In 2000, the fumigant-related compound carbon tetrachloride was detected in public water supply well PWS 68-1 (Figure 1.2), at a trace level. Low-level contamination, below the maximum contamination level (MCL) of $5.0 \mu \mathrm{g} / \mathrm{L}$, has been detected intermittently in well PWS 68-1 since 2000, including in the last sample taken in July 2013. In 2006, the village installed a new well, PWS 2006-1, that remains free of contamination.

Prior to 1985, two grain facilities were in operation in Bladen. In 1950-1974, the Commodity Credit Corporation of the U.S. Department of Agriculture (CCC/USDA) operated a grain storage facility (currently owned by CHS, Inc.) south of the railroad right-of-way in Bladen. The other grain operation prior to 1985 was on the second parcel currently owned by CHS, Inc., on the railroad right-of-way (Figure 1.2). Until 1985, commercial grain fumigants containing carbon tetrachloride were in common use at public and private grain operation facilities across the state. Contaminated well PWS 68-1 is located about $700 \mathrm{ft}$ northwest of the former CCC/USDA facility and adjacent to the northern edge of the CHS parcel on the railroad right-of-way.

In May 2012, the Remediation Section of the Nebraska Department of Environmental Quality (NDEQ) completed a pre-CERCLIS site screening assessment (NDEQ 2012). In this assessment, the NDEQ (1) suggested that the former CCC/USDA grain storage facility is a potential source of carbon tetrachloride contamination detected in well PWS 68-1; (2) recommended sampling of groundwater in three private wells in the vicinity of the village; and (3) indicated that the groundwater flow is to the north, likely with a westerly component toward the Little Blue River. In September 2012, the CCC/USDA sampled five private wells, including the three requested by the NDEQ, for carbon tetrachloride, chloroform, and methylene chloride. No contamination was identified in the private wells tested.

Because the carbon tetrachloride found in well PWS 68-1 might be linked to historical use of fumigants containing carbon tetrachloride at grain storage facilities, including its former facility in Bladen, the CCC/USDA is proposing an investigation to (1) delineate the source and 
extent of the carbon tetrachloride contamination potentially associated with its former facility, (2) characterize pathways and controlling factors for contaminant migration in the subsurface, and (3) establish a basis for estimating potential health and environmental risks. The work will be performed in accordance with the Intergovernmental Agreement established between the NDEQ and the Farm Service Agency of the USDA.

The site investigation at Bladen will be implemented in phases, so that data collected and interpretations developed during each phase can be evaluated to determine if a subsequent phase of investigation is warranted and, if warranted, to provide effective guidance for the subsequent investigation activities. This Work Plan identifies the specific technical objectives and defines the scope of work proposed for the Phase I investigation by compiling and evaluating historical data. The proposed investigation activities will be performed on behalf of the CCC/USDA by the Environmental Science Division of Argonne National Laboratory. Argonne is a nonprofit, multidisciplinary research institute operated by UChicago Argonne, LLC, for the U.S. Department of Energy. 


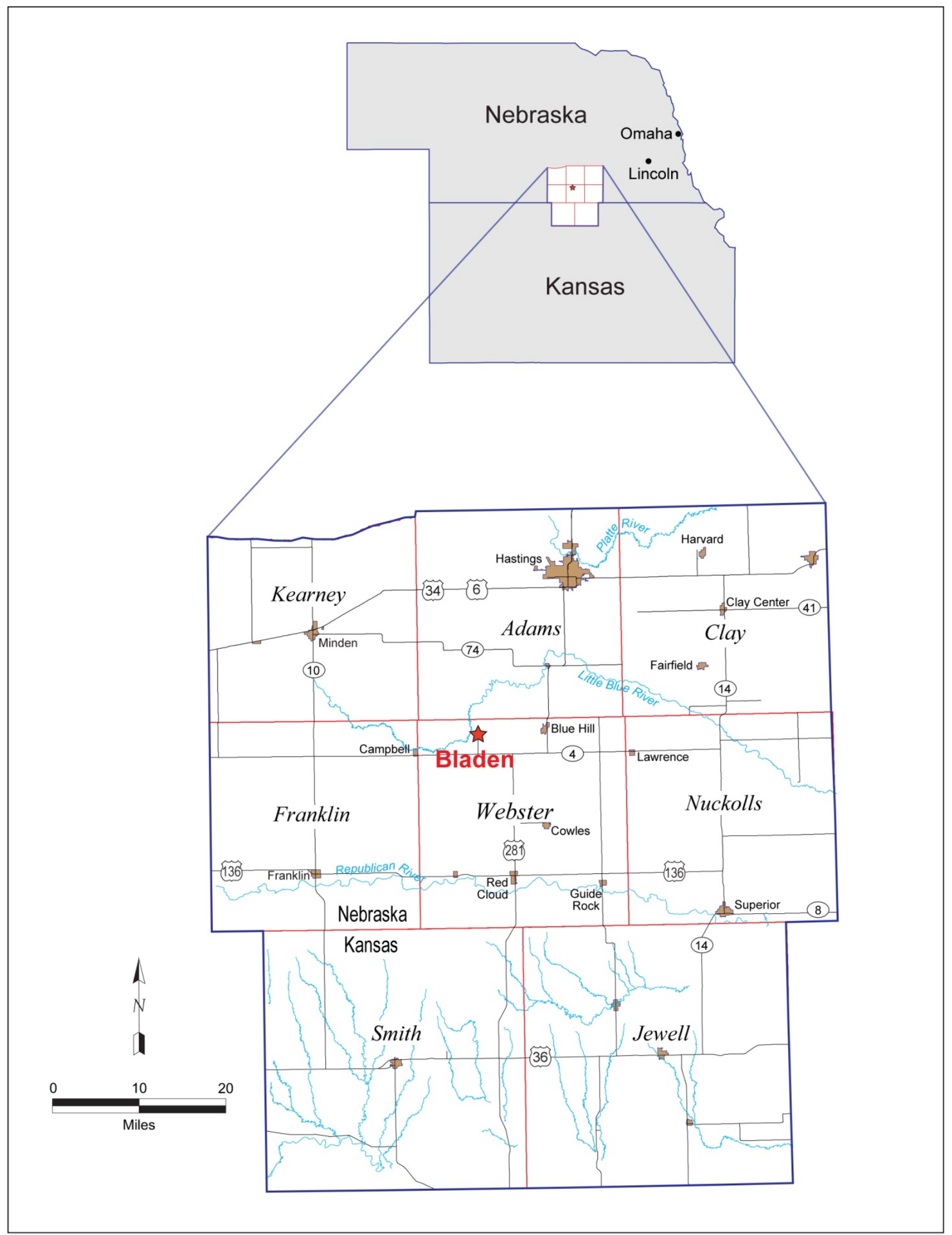

FIGURE 1.1 Location of Bladen, Nebraska. 


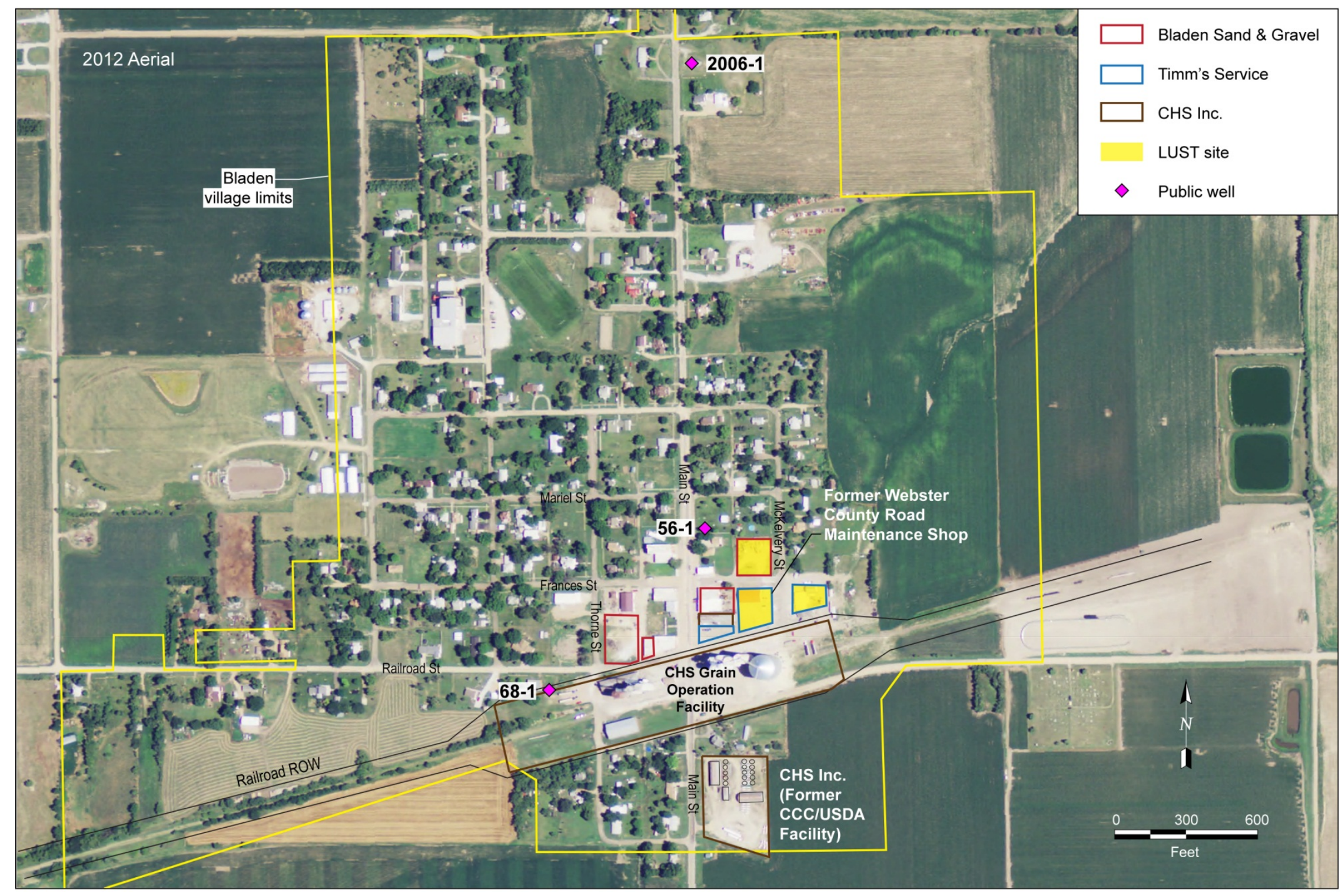

FIGURE 1.2 Locations of the former CCC/USDA facility, nearby agricultural business facilities, leaking underground storage tank sites, and public water supply wells. Source of photograph: NAIP (2012). 


\section{Background and Previous Studies}

\subsection{Site Background}

\subsubsection{Area Description}

Bladen is a small village in northwestern Webster County, Nebraska, extending across the four corners at the intersection of Sections 7, 8, 17, and 18 of Township 4 North, Range 11 West. The village has several small businesses and local agricultural services, including CHS, Inc., Bladen Sand and Gravel, and Timm's Service (Figure 1.2). The village also hosts the Silver Lake Elementary School, a post office, the Webster County shop, churches, and a fire station.

The 2010 Census recorded 237 residents in 93 housing units in the village of Bladen. The village is served by a public water supply system that obtains its water from two wells (PWS 68-1 and PWS 2006-1) within the village limits (Figure 1.2). The wells are used on a alternating basis. All residences within the village limits are served by these wells.

The major agricultural service company CHS, Inc., has owned two grain operation facilities at Bladen since 2009. One is located on the railroad right-of-way, along the abandoned railroad branch still owned by the Burlington Northern Santa Fe Railroad. The other, located south of the railroad right-of-way, was leased to the CCC/USDA for use as a grain storage facility in 1950-1974 (Figure 1.2). CHS, Inc., is nationwide cooperative system. Its Bladen facilities provide grain storage, management, and wholesale services for the local farmers. Bladen Sand and Gravel operates and supports trucks that provide sands and gravels to many Nebraska counties. Timm's Service offers fuel supply to the local community.

\subsubsection{Bladen Public Water Supply}

The village of Bladen has had three public water supply wells (PWS 2006-1, PWS 68-1, and PWS 56-1). Well PWS 56-1, the oldest of these, was abandoned after PWS 68-1 was installed. Well PWS 2006-1 was installed in September 2006 and was placed in service in August 2007. Since then, the public water supply system at Bladen has been supported by wells PWS 68-1 and PWS 2006-1. The village maintenance superintendent indicated that the Bladen 
public water supply system provides water to every household within the village limits, as well as a local school, for a total population of 311 (Pavalkan 2014).

Wells 2006-1 and 68-1 are approximately 2,700 ft apart. Well 68-1 is located at the northern edge of the CHS grain facility on the railroad right-of-way, and about $700 \mathrm{ft}$ northwest of the former CCC/USDA facility. Well 2006-1 is more distant from both grain operation facilities: 2,400 ft from the CHS facility on the railroad right-of-way and 2,900 ft from the former CCC/USDA facility (Figure 1.2). Groundwater samples from wells PWS 68-1 and PWS 2006-1 have been tested for volatile organic compounds (VOCs) every 2-5 yr. Since a trace level of carbon tetrachloride $(0.47 \mu \mathrm{g} / \mathrm{L})$ was first detected at PWS $68-1$ in 2000, carbon tetrachloride has been identified in five of nine sampling events, at low concentrations of 2.99-3.83 $\mu \mathrm{g} / \mathrm{L}$ (below the MCL of $5.0 \mu \mathrm{g} / \mathrm{L}$ ). Chloroform was detected only once in PWS 68-1, at the low concentration of $4.3 \mu \mathrm{g} / \mathrm{L}$ in 2005. Well PWS 2006-1 was tested for VOCs in 2009 and 2012. No carbon tetrachloride or chloroform was detected. The analytical results for carbon tetrachloride and chloroform in groundwater samples from both wells are in Table 2.1. In addition to VOCs testing, wells PWS 68-1 and PWS 2006-1 have also been sampled quarterly for nitrate. Slightly higher concentrations of nitrate have been found at well PWS 68-1 (8-10 mg/L) during JulyAugust of the last $3 \mathrm{yr}$, coinciding with the peak of the irrigation season in the vicinity of the village. Corresponding elevated nitrate concentrations have not been detected in July-August during the last 3 yr at PWS 2006-1 (less than $5 \mathrm{mg} / \mathrm{L}$; NDHHS 2014).

Wells PWS 68-1 and PWS 2006-1 have been operated alternately, with an approximate mixing ratio of 35\% (PWS 68-1) to 65\% (PWS 2006-1). Pumping records for the period of 20072013 (Pavalkan 2014) indicate a monthly pumping volume ranging from 1.04 million gallons (November 2013) to 5.98 million gallons (July 2012). Wells PWS 68-1 and PWS 2006-1 were both installed in an aquifer hosted by Quaternary sand and gravel, which unconformably overlies the Upper Cretaceous bedrock (Niobrara shale) and has a consistent thickness of 16-17 ft at depths of 152-169.5 ft below ground level (BGL). However, the PWS 2006-1 borehole is grouted from $127 \mathrm{ft} \mathrm{BGL}$ to $17 \mathrm{ft} \mathrm{BGL}$ with bentonite and from $17 \mathrm{ft}$ BGL to the ground surface with concrete. In contrast, PWS 68-1 is sealed with clay only from $40 \mathrm{ft}$ BGL to $20 \mathrm{ft}$ BGL and with concrete from $20 \mathrm{ft}$ BGL to the ground surface (Appendix A). The estimated pumping rates are approximately $550 \mathrm{gpm}$ at PWS 68-1 and $450 \mathrm{gpm}$ at PWS 2006-1 (Pavalkan 2014). The ungrouted interval of 40-169.5 ft BGL at PWS 68-1 might expose more of the stratigraphic sequence and thereby increase the pumping capacity of the well, but it could also make the well more vulnerable to contamination from the surface. 


\subsubsection{Wellhead Protection Area for the Public Water Supply Wells}

The NDEQ Wellhead Protection (WHP) Program has developed a wellhead protection area (WHPA) for each public water supply system in Nebraska. The WHPA for Bladen wells PWS 68-1 and PWS 2006-1 was developed in November 2009. The assumptions and the well data used for development of the WHPA and the derived WHPA map are in Appendix B.

In development of the WHPA for the Bladen public water supply system, the NDEQ determined that the local groundwater flow is to the north-northwest, on the basis of water level data collected from 43 water wells in the surrounding area. In addition, the NDEQ estimated that the aquifer has an average thickness of $28 \mathrm{ft}$, with hydraulic conductivity of $168 \mathrm{ft} / \mathrm{day}$ and porosity of 0.2 , on the basis of well logs and testing information for five water wells in the vicinity of Bladen (Appendix B). In the pumping scenario serving as the basis for the WHPA, the NDEQ assumed that the two public water supply wells withdraw groundwater at constant rates of $17 \mathrm{gpm}$ and $34 \mathrm{gpm}$ for $20 \mathrm{yr}$. The time-of-travel lines for water particles captured by the pumping wells were created by using the U.S. Environmental Protection Agency (EPA) Wellhead Analytic Element Model (WhAEM2000; EPA 2014a). The WHPA was drawn slightly larger than the 20-yr time-of-travel lines to allow for seasonal changes and some natural variability in the aquifer (Appendix B).

The WHPA and the 20-yr time-of-travel lines derived by the NDEQ suggest that (1) all of the former and current grain storage facilities are located within the WHPA and (2) the eastern portion of the CHS grain operation facility on the railroad right-of-way and the former CCC/USDA facility are not within the estimated time-of-travel lines captured by the pumping of well PWS 68-1. As indicated by the NDEQ WHP Program, however, the predicted WHPA is based on general, homogeneous assumptions and might not represent the actual capture zones of pumping wells under site-specific pumping configurations in a heterogeneous aquifer.

\subsection{Previous Investigations}

Several sampling events and investigations have been conducted for groundwater at Bladen. The main investigation activities are as follows:

- Soil and groundwater investigations for three leaking underground storage tank (LUST) sites identified in the 1990s. 
- Private well sampling conducted by Woodward Clyde for the CCC/USDA in 1997.

- A pre-CERCLIS site screening assessment conducted by the NDEQ Remediation Section in 2012.

- Private well sampling conducted by Argonne for the CCC/USDA in June 2012.

The results of the previous investigations are discussed below.

\subsubsection{Investigations of Leaking Underground Storage Tank Sites}

During the 1990s, three LUST sites were identified at Bladen. The sites were operated by Bladen Sand and Gravel, Timm's Service, and the Webster County Roads Maintenance Shop (currently owned by Timm's Service). The locations of the sites are shown in Figure 1.2.

\subsubsection{LUST Site at Bladen Sand and Gravel}

The Bladen Sand and Gravel LUST site is one block east of Main Street and one block north of the railroad right-of-way (Figure 1.2). The site was used to store trucks and provide maintenance service for vehicles. In October 1991, a petroleum release was noticed, and one 10,000-gal underground diesel fuel tank and associated dispensers were removed. Petroleum contamination was identified in soil samples collected during the excavation. In 1993, the NDEQ requested that Bladen Sand and Gravel conduct a Step 6 Initial Site Assessment.

In June 1993, Geotechnical Services, Inc. (GSI), on behalf of Bladen Sand and Gravel, conducted a soil and groundwater investigation for the Step 6 Initial Site Assessment. A single borehole was drilled through the tank excavation area to a depth of $106 \mathrm{ft}$ BGL. Soil samples were collected for every $5 \mathrm{ft}$ from the ground surface to $50 \mathrm{ft}$ BGL and every $10 \mathrm{ft}$ from $50 \mathrm{ft}$ to $106 \mathrm{ft}$ BGL. The headspace of the soil samples was analyzed on-site with an organic vapor analyzer. No contamination was identified above the detection limit. Groundwater was encountered at a depth of $99 \mathrm{ft}$ BGL, and a monitoring well was installed with 10-ft screen at the base of the borehole. Groundwater samples were collected after well construction and 
development. Samples were sent to an analytical laboratory for analysis for petroleum compounds (total recoverable petroleum hydrocarbons [TRPH] and benzene, toluene, ethylbenzene, and xylene [BTEX]). No petroleum compounds were detected in the groundwater samples (GSI 1993). The expectation was to abandon the monitoring well after completion of the assessment report.

GSI (1993) reported that the lithology encountered during the drilling was mainly a loess unit (silty clay to silt), with some fine sand at the base of borehole where groundwater was encountered. No hydraulic testing was conducted for the groundwater-bearing zone.

\subsubsection{LUST Site at Timm's Service}

Timm's service station is on the southeast corner of the intersection of Frances Street and North McKelvey Street, just north of the railroad right-of-way (Figure 1.2). In 1997, petroleum contamination was identified beneath two 2,000-gal gasoline tanks, one 2,000-gal diesel fuel tank, and associated pipelines and dispensers at the station. The underground tanks and pipes were removed in November 1997, and a closure assessment report was filed (NDEQ 1998). On September 22, 1998, the NDEQ notified Timm's Service that a site investigation and cleanup (if necessary) might be required at a future date. In 2004, the NDEQ requested that Timm's Service conduct a Tier I investigation at the LUST site (GSI 2004b).

In December 2004, GSI, on behalf of Timm's Service, conducted soil sampling for the Tier I site investigation. One soil boring was advanced to $35 \mathrm{ft} \mathrm{BGL}$, and soil samples were collected at 5-10 ft, 20-25 ft, and 30-35 ft BGL. No contamination was detected (GSI 2004b) upon laboratory analysis of the soil samples for petroleum compounds (BTEX and TRPH). The investigation was terminated, and no groundwater samples were collected.

\subsubsection{LUST Site at Webster County Roads Maintenance Shop}

The former Webster County Roads Maintenance Shop, operated by the Webster County Roads Department, was on the property currently owned by Timm's Service. The former shop was located on the southwest corner of the intersection of Frances Street and North McKelvey Street, north of the railroad right-of-way (Figure 1.2). The shop had two underground storage tanks, one for gasoline and the other for diesel fuel, to support the county's maintenance 
operations. In October 1997, a suspected leak was reported, and two tanks were removed by Petroleum Equipment, Inc. Screening of the soil samples collected during excavation for petroleum compounds indicated contamination around the fuel diesel tank. On July 22, 1998, the NDEQ notified the Webster County Roads Department that a site investigation and cleanup (if necessary) might be required at a future date. In 2004, the NDEQ requested the Webster County Roads Maintenance Shop to conduct a Tier I investigation at the LUST site (GSI 2004a).

In August 2004, GSI, on behalf of the Webster County Roads Department, conducted soil sampling for the Tier I site investigation. Two soil borings were advanced to $20 \mathrm{ft}$ and $35 \mathrm{ft}$ BGL, and soil samples were collected every $5 \mathrm{ft}$. The soil samples were screened in the field with an organic vapor analyzer. Five selected samples were sent to an analytical laboratory for analysis of petroleum compounds (BTEX, TRPH, etc.). No contamination was detected in soil samples collected below $5 \mathrm{ft}$ BGL (GSI 2004a). The investigation was terminated, and no groundwater samples were collected.

\subsubsection{Woodward Clyde Private Well Sampling for the CCC/USDA in 1997}

In October-November 1997, Woodward Clyde, on behalf of the CCC/USDA, conducted statewide groundwater sampling of private wells near former CCC/USDA facilities in Nebraska. Near Bladen, two private wells were identified at the Karr and Moriarty residences, 1,300-1,500 $\mathrm{ft}$ west of the western village limit (Figure 2.1). In groundwater samples from the wells analyzed for VOCs, neither carbon tetrachloride nor chloroform was found above the detection limits (Woodward Clyde 1997). The two wells were resampled by Argonne for the CCC/USDA in 2012, with the same results (Section 2.2.4). The results are in Table 2.2.

\subsubsection{NDEQ Pre-CERCLIS Site Screening Assessment in 2012}

In 2012, the NDEQ Remediation Section conducted a desktop pre-CERCLIS site screening assessment in response to the low-level contamination detected in well PWS 68-1 (NDEQ 2012). In this assessment, the NDEQ Remediation Section compiled available data and documents to identify any potential impacts to the existing public and private wells. The documents collected included information on the village public water supply wells, the state WHP Program, private wells, previous surveys, and the property the CCC/USDA formerly leased. The assessment identified three residences that might be using private wells as their 
primary water sources. These three residences (Karr, Kaufman, and Niemeyer) are located outside the village limits but are within $1 \mathrm{mi}$ of the village boundaries (Figure 2.1).

In its assessment, the NDEQ (2012) confirmed the location of the former CCC/USDA grain storage facility in the southern part of Bladen and collected information on groundwater flow from the state WHP Program. The NDEQ identified the former CCC/USDA facility as a potential source of contamination.

On the basis of findings of the assessment, the NDEQ requested sampling of the private wells at the Karr, Kaufman, and Niemeyer residences. The groundwater sampling for the private wells at these residences was performed in September 2012, as discussed below.

\subsubsection{Argonne Private Well Sampling for the CCC/USDA in September 2012}

In response to the NDEQ's recommendation in its Pre-CERCLIS site screening assessment, the CCC/USDA directed Argonne to conduct groundwater sampling for private wells in and near Bladen. In September of 2012, Argonne contacted the village and, within $1 \mathrm{mi}$ of the former CCC/USDA facility, identified one livestock well (Kaufman) and four private residential wells (Karr, Kaufman, Moriarty, and Niemeyer) that are currently in use for water supply. The distance from the former CCC/USDA facility to the private wells ranges from $900 \mathrm{ft}$ to $4,500 \mathrm{ft}$. The locations of these private wells are shown in Figure 2.1.

The groundwater samples collected from the five private wells in 2012 were analyzed for VOCs. No carbon tetrachloride or chloroform was found above the detection limits. The results are listed in Table 2.2 and illustrated in Figure 2.1.

\subsection{Geologic and Hydrogeologic Setting}

The village of Bladen lies in the High Plains section of the Great Plains province (http://tapestry.usgs.gov/physiogr/physio.html). The surface topography is typically characterized as relatively flat uplands and gently rolling hills with narrow channels of tributary valleys along the streams (Figure 2.2). The area surrounding the village of Bladen is drained mainly by a headwaters reach of the Little Blue River to the west and a tributary, Flat Creek, to the east. Both streams flow to the north and enter the main reach of the Little Blue River, which 
is the principal stream in the region (Figure 2.2). The land surface elevations in the village of Bladen range from uplands at 1,980-1,990 ft above mean sea level (AMSL) to the headwaters and tributary creeks at 1,910-1,950 ft AMSL to the west and the east, respectively (Figure 2.3). The local relief is less than $100 \mathrm{ft}$.

The upland plain in the vicinity of Bladen consists of remnants of thick loess deposits partly dissected by the surface drainage system. Because the local drainage system does not cut through the loess plain into the underlying major aquifers, all the local creeks have intermittent flow and apparently receive no groundwater discharge. The perennial stream flow in the Little Blue River system starts in the middle part of Adams County, about 14 mi northeast of Bladen (Figure 1.1; Little Blue Natural Resources District [Little Blue NRD 2011]). At the origin of the perennial stream of the Little Blue River, the flow turns abruptly from northeasterly to southeasterly at a surface elevation below $1,810 \mathrm{ft}$ AMSL, along a stream valley that is expected to dissect the entire loess plain to the major aquifers in the region.

\subsubsection{Regional Geology and Hydrogeology}

The subsurface geologic materials in Webster County consist mainly of the following, in ascending order: (1) Niobrara Formation of late Cretaceous age, including chalk, limestone, and shale; (2) Pierre Shale of late Cretaceous age, including clay shale, claystone, marl, shaly sandstone, and sandy shale; (3) Ogallala Group of Tertiary age, developed on the eroded surface of the Niobrara Formation or the Pierre Shale, with poorly sorted coarse rock debris; and (4) a thick layer of Pleistocene loess mantling the entire area, with alluvial deposits near the base of the paleovalleys overlying the bedrock.

The Niobrara Formation consists of argillaceous chalk, limestone, and shale. The chalk is medium gray to white, interbedded with thin layers of chalky shale, while the limestone is light gray to medium gray and yellowish gray, interbedded with medium gray chalky shale. Regionally, the thickness ranges up to $570 \mathrm{ft}$.

Overlying the Niobrara Formation, the Pierre Shale is predominately a fissile clay shale, medium to dark gray, brownish gray, and black in color. It can also locally contain thin beds of calcareous, silty shale or claystone, marl, shaly sandstone, and sandy shale. The maximum reported thickness of the Pierre Shale ranges up to $1,970 \mathrm{ft}$ in the region. 
The active mountain building to the west marks the end of Cretaceous time. Most of the deformation in the area occurred after the Pierre Shale was deposited but before deposition of the Ogallala Group. Periodic uplifting resulted in periods of erosion, deposition, and stability during the Tertiary. The Cretaceous rock currently dips gently to the northwest at about $11 \mathrm{ft} / \mathrm{mi}$ in Franklin and Webster Counties (Miller et al. 1964).

The Ogallala Group (Pliocene epoch) overlying the Pierre Shale typically forms major deposits (broad fans of rock debris) derived from the western mountains that encroached on the area during a fairly long period of erosion and valley formation across Nebraska. The Ogallala Group is composed of inter-fingered, fine- to coarse-grained, poorly sorted, arkosic, fluvial deposits of light gray, light olive-gray, and grayish green calcareous silt and sand. These deposits are locally poorly consolidated conglomerate, sandstone, and siltstone. South-central Nebraska is at the eastern edge of the Ogallala deposits, and erosion removed much of the Ogallala Group in the region at the close of Pliocene epoch (Miller et al. 1964). The remnants of the Ogallala Group are limited to isolated areas in Webster County.

Overlying the Ogallala Formation or Upper Cretaceous Pierre Shale are Pleistocene and recent deposits, consisting mainly of undifferentiated coarse-grained deposits (Red Cloud sand and gravel and Grand Island Formation) and the overlying loess that mantles most of the area. The Red Cloud and Grand Island deposits consist of alluvial coarse sand derived from the Rocky Mountains. Although Schultz et al. (1951) redefined the coarse fluvial deposits of Kansas age into the Red Cloud sand and gravel of early Kansas age and the Grand Island Formation of late Kansas age, the differentiation between the two units was difficult and was not adopted by the U.S. Geological Survey (USGS; Miller et al. 1964). The two coarse-grained units of Kansas age were combined as the Grand Island Formation by Miller et al. (1964).

Loess deposits in Nebraska can be further subdivided as the Loveland Formation and the Peorian Loess, correlating with glaciation stages (Johnson 1960). The Loveland Formation, of eolian origin and consisting of reddish brown calcareous silt with minor amounts of sand and clay, covers both the drainageways and the low divides. The overlying light brown to nearly white Peorian loess contains nodular calcareous concretions and mantles most of the area.

The Quaternary alluvial coarse-grained deposits (Grand Island Formation) constitute a major aquifer in Webster, Adams, Clay, and Nuckolls Counties. The aquifer is confined by the underlying Niobrara Formation chalk and shaly limestone or Pierre Shale and is overlain by a 
thick loess mantle (Pleistocene). A recent hydrogeologic study (Little Blue NRD 2011) indicated that the thickness of the aquifer might vary from less than $10 \mathrm{ft}$ in the upland plain and more than $250 \mathrm{ft}$ along the major Little Blue River valley, about $10 \mathrm{mi}$ northeast of Bladen. The Little Blue NRD (2011) compiled groundwater level data collected in 2010, suggesting that groundwater in the aquifer mainly flows from west to east and east-southeast along the Little Blue River Valley in the region. However, in the area surrounding Bladen, groundwater flows to the northwest, toward the Little Blue River valley.

\subsubsection{Local Geology and Hydrogeology}

Geologic and hydrogeologic information for the Bladen area was obtained from state test hole records and water well registration records. To illustrate the configuration of local geologic and hydrogeologic units, three geologic cross sections were constructed by using the geologic logs from test holes and lithologic descriptions of selected private water wells within 1 mi of well PWS 68-1. Locations of all test holes and wells used to construct the cross sections are shown in Figures 2.2 and 2.3. Individual logs are in Appendix C.

In the vicinity of Bladen, five test holes were identified. Three of these, 53-B-47, 23-B-81, and 25-B-49 (Figure 2.2), were selected to construct geologic cross section A-A' across Bladen and the surrounding area. Test hole 53-B-47, 7 mi northwest of Bladen, has a total depth of $240 \mathrm{ft}$ and penetrates the Quaternary loess, the basal sand unit, and the Tertiary Ogallala Formation to the top of late Cretaceous Pierre Shale (Figure 2.4). Test hole 25-B-49, about 5 mi east of Bladen, penetrates the Quaternary loess and the Tertiary Ogallala Formation and reaches the top of the Niobrara Formation. Test hole 23-B-81 - the closest to Bladen, 2 mi to the northwest - was drilled to $200 \mathrm{ft}$ BGL, penetrating Quaternary loess and a thick unit of sand and gravel to the top of Niobrara Formation.

On the basis of state water well registration records, 18 private water wells and 1 village test well were identified within $1 \mathrm{mi}$ of well PWS 68-1. The private water wells include 15 irrigation wells, 2 domestic wells, and 1 livestock well. In addition, 1 test well owned by the village of Bladen was drilled for installation of PWS 2006-1. The locations of these wells are shown in Figure 2.2. The depths of these local-area wells are consistently in the range of 114-189 ft BGL, except that one irrigation well has no recorded well depth. 
Cross section A-A' (Figure 2.4) extends for approximately $13 \mathrm{mi}$ from west to east, connecting test holes, local private water wells, and Bladen well PWS 68-1 (Figure 2.2). Two shorter cross sections (B-B' and $\mathrm{C}^{\left.-\mathrm{C}^{\prime}\right)}$ illustrate details of the local geology recovered in private water wells and well PWS 68-1 across the village of Bladen, along the north-south and west-east directions, respectively (Figures 2.3 and 2.5-2.6).

The interpretations presented in longer cross section A-A' (Figure 2.4) indicate four geologic units in descending order: (1) an undifferentiated Quaternary deposit including an eolian loess unit (silt and clay) and an underlying sand and gravel unit, with a total thickness of 99-178 ft; (2) the Tertiary Ogallala Group (silt, sand, and sandstone) occurring only at the west and east ends of the A-A' cross section, outside Bladen; (3) late Cretaceous Pierre Shale recovered at test hole 53-B-47; and (4) late Cretaceous Niobrara Formation chalk and shale. The two local geologic cross sections (B-B' and $\mathrm{C}^{-\mathrm{C}^{\prime}}$ ) across the village of Bladen illustrate a simpler stratigraphic profile within $1 \mathrm{mi}$ of well PWS 68-1: Quaternary loess and sand and gravel units directly overlying the late Cretaceous Niobrara Formation (Figures 2.5-2.6).

The local principal aquifer consists primarily of the sand and gravel unit in the lower section of the Quaternary deposit. This sand and gravel unit includes two layers: (1) a lower layer of sand and gravel overlying on the unconformable surface of the Niobrara bedrock and (2) an upper layer of sand in the loess unit. The lower layer of sand and gravel was present at the location of every local water well and was completely saturated, providing the source of groundwater for the wells. The thickness of the layer ranges from $9 \mathrm{ft}$ to $38 \mathrm{ft}$ (cross section C-C', Figure 2.6). The upper layer of sand extends along the north-south direction but is limited to the area surrounding the village of Bladen along the west-east direction. The upper layer might be partially saturated but is not the main source of groundwater for the water wells.

In developing the WHPA for the Bladen public water supply system, the NDEQ WHP Program collected water level data from 43 water wells in the vicinity of Bladen and determined a general groundwater flow direction to the north-northwest in the regional principal aquifer. More detailed measurements are needed to identify the groundwater flow patterns near the former CCC/USDA facility, with and without stress from pumping wells in the area. 


\subsection{Identification of Potential Contaminant Source Areas}

Carbon tetrachloride contamination previously found in soil and groundwater in a number of rural communities in Nebraska has been determined to be related to grain storage operations at former CCC/USDA and commercial/private grain storage/operation facilities that were active prior to 1985. On the basis of results for public well sampling and previous investigations (Sections 2.1 and 2.2), carbon tetrachloride contamination has been identified in groundwater of the Quaternary aquifer at one location (well PWS 68-1) in Bladen. Low concentrations of carbon tetrachloride $(0.47-3.83 \mu \mathrm{g} / \mathrm{L})$ were detected in 6 of 10 sampling events (Table 2.1). To identify potential source areas for the groundwater contamination at well PWS 68-1, Argonne conducted a property document search, collected community information, and reviewed historical aerial photographs. This section presents the results of the combined analyses of all documentation available to the public.

Through a review of historical aerial photographs taken in 1956, 1963, 1969, and 2012 and local community information, two types of grain storage/operation facilities were identified at Bladen (Figure 2.7). These facilities are (1) the former CCC/USDA grain storage facility south of the railroad right-of-way, at the southeastern edge of Bladen, and (2) the private grain operation facility along the railroad right-of-way, north of the former CCC/USDA facility. Contaminated well PWS 68-1 is located at the northern boundary of the railroad right-of-way. Both of the grain facilities in operation before 1985 are currently owned by CHS, Inc., a farmerowned cooperative with headquarters at Inver Grove Heights, Minnesota. The railroad has been abandoned. However, the property on which the tracks were laid and the right-of-way are still owned by the Burlington Northern Santa Fe Railroad.

The historical ownership of the former CCC/USDA grain storage property was determined on the basis of documents acquired from the Register of Deeds, Webster County, located in Red Cloud, Nebraska. The historical ownership and property records are summarized in Table 2.3, and the property records are reproduced in Appendix D.

Information on historical ownership of private grain operation facilities on the railroad right-of-way was obtained from a village centennial history publication (Bladen Opera House Centennial Book Committee 1986) and relevant records for properties near the railroad right-ofway. 


\subsubsection{Former CCC/USDA Grain Storage Facility and Subsequent Grain Operations}

The former CCC/USDA facility was located east of Main Street at the southern edge of Bladen. On the basis of the property documents obtained from the Register of Deeds for Webster County, a three-acre parcel was initially leased by the CCC/USDA from R.C. Humes in April 1950, for $5 \mathrm{yr}$. The lease was renewed once for $5 \mathrm{yr}$ and twice for $10 \mathrm{yr}$. During this time, the 9.2-acre property including the CCC leasehold was conveyed to Arthur and Stella Morey in 1957 and to Carl and Eva Hubert in May 1958. The lease was terminated before the end of the second 10-yr lease, and the property was released to the Huberts in August 1974 (Table 2.3). Historical aerial photographs show grain storage activities on the former CCC/USDA facility that are consistent with the lease term. The 1956, 1963, and 1969 aerial photographs show 2 steel Quonsets (40,110 bushels each), 1 storage building between the 2 Quonsets, and 15 circular Eaton aluminum bins (3,250 bushels each) on the former CCC/USDA facility (Figure 2.7). The total grain storage capacity was 128,970 bushels during the facility's peak time. Five bins were removed before 1993 (after 1974), and the rest were removed before 1999 (Figure 2.8). However, two Quonsets and one small storage building, as well as the concrete bases of four circular bins, still remain at the present time.

The Huberts' property that had been leased to the CCC/USDA in 1950-1974, with storage Quonsets and bins, was subsequently conveyed to the Farmers Coop in 1978 and to the Coop Grain and Supply Company, Roseland, Nebraska, in 1980. In 1995, the Agri Coop purchased the property; most of grain storage bins were removed in this time frame. In 2009, Agri Coop merged with the CHS Holdrege, Inc. (currently CHS, Inc.), which is a nationwide cooperative agribusiness company (Figure 2.9).

On the basis of the groundwater flow direction in the Quaternary aquifer, as determined by the NDEQ WHP Program and the Little Blue NRD (2011), the former CCC/USDA facility is not upgradient of well PWS 68-1 under the ambient groundwater flow condition. In addition, under the 20-yr pumping scenario defined by the WHP Program, groundwater at the former CCC/USDA facility would not be captured by well PWS 68-1. However, the former CCC/USDA facility is in the general wellhead protection area established by the WHP Program through consideration of the potential complexity of aquifer properties and variations of pumping scenarios in the area. 


\subsubsection{Private Grain Operation Facility along the Railroad Right-of-Way}

The private grain operations have been located primarily on the railroad right-of-way. The grain operations on the property formerly leased by the CCC/USDA, south of the right-ofway, are discussed in Section 2.4.1. The private facilities on the right-of-way, expanded over decades, were operated by local farmers or coops, including McNeil, Bladen Grain Company, Coop Grain and Supply Company, Agri Coop, and CHS, Inc.

In 1956 aerial photograph (Figure 2.7) shows three elevators along the railroad right-ofway. These elevators were built or remolded in the early 1950s. An office building and a Quonset (40,110 bushels) added in the mid 1950s appear on 1963 and 1969 aerial photographs. The grain operation facility was owned by McNeil in the 1950s and 1960s, until 1970 (Bladen Opera House Centennial Book Committee 1986). The Bladen Grain Company managed the facility from 1970 to 1978 and then sold it to the Coop Grain and Supply Company. In 1982, the Coop Grain and Supply Company added six concrete silos on the east and two silos on the west, with a total added capacity of 400,000 bushels (Bladen Opera House Centennial Book Committee 1986). These new grain storage structures are shown on the 1993 and 1999 aerial photographs (Figure 2.8). In the mid 1980s, the facility on the right-of-way was operated in conjunction with the Roseland and Blue Hill Coops. In 1995, the grain operation facility was sold to Agri Coop, which merged with CHS, Inc., in 2009.

Well PWS 68-1 is located toward the western end of the northern boundary of the CHS grain operation facility on the railroad right-of-way (Figure 2.9). On the basis of groundwater flow direction, the entire western portion of the grain operation facility is upgradient of well PWS 68-1 under both ambient and pumping conditions.

\subsection{Summary}

As discussed above, all local background information, results of previous investigations, regional and local geologic data, and historical documents were compiled and evaluated in this site review. The main findings of the review are summarized as follows:

- Groundwater contamination associated with grain fumigation at Bladen has been identified at only one location: well PWS 68-1. Carbon tetrachloride has been detected intermittently at low concentrations of $0.47-3.83 \mu \mathrm{g} / \mathrm{L}$ (below 
the MCL) since 2000. No carbon tetrachloride has been detected at well PWS 2006-1.

- Three LUST sites have been identified at Bladen. No VOCs analyses have been conducted for soil or groundwater at these sites.

- Carbon tetrachloride and chloroform have not been detected in any private water wells in the vicinity of Bladen, including two wells sampled by Woodward Clyde for the CCC/USDA in October-November 1997 and five wells tested by Argonne for the CCC/USDA in September 2012.

- The regional geologic sequence, in ascending order, consists of (1) Upper Cretaceous Niobrara Formation including chalk, shale, and limestone; (2) Upper Cretaceous Pierre Shale; (3) Tertiary Ogallala Group (alternating beds of silt, sand, and sandstone); and (4) a thick layer of Pleistocene loess mantling the entire area, with alluvial deposits near the bottom of the paleovalleys over the bedrock. The local geologic sequence within $1 \mathrm{mi}$ of Bladen is expected to be simplified to Quaternary loess and sand and gravel units (99-178 ft) directly overlying the Upper Cretaceous Niobrara chalk, shale, and limestone.

- The local principal aquifer consists primarily of the sand and gravel unit in the lower section of Quaternary deposit, overlying the unconformable surface of the Niobrara bedrock. The aquifer extends laterally across the entire area and is vertically confined by the overlying loess unit and the underlying Niobrara chalky shale, which has a thickness of 9-38 ft. The NDEQ WHP Program suggests, on the basis of regional water well information, that the Quaternary aquifer exhibits a hydraulic conductivity of $168 \mathrm{ft} /$ day and that groundwater flows north-northwest.

- Wells PWS 68-1 and PWS 2006-1 are operated alternately, with an approximate mixing ratio of 35\% (PWS 68-1) to 65\% (PWS 2006-1). Both wells were installed in the Quaternary aquifer and have similar screen intervals (16-17 ft) at depths of 152-169.5 ft BGL. 
- The ungrouted interval of 40-153.5 ft at well PWS 68-1 might increase the pumping capacity of the well but could make the well more vulnerable to contamination from the local surface. The borehole of PWS 68-1 is sealed only from $40 \mathrm{ft}$ BGL to the ground surface, while the borehole of PWS 2006-1 is grouted from $127 \mathrm{ft}$ BGL to the ground surface. The estimated pumping rates are about 550 gpm at PWS 68-1 and 450 gpm at PWS 2006-1.

- Two types of grain storage facilities have been identified as potential source areas of the groundwater contamination associated with historical grain fumigation: (1) the former CCC/USDA facility south of the railroad right-ofway, located $700 \mathrm{ft}$ southeast of well PWS 68-1, and (2) the private grain operation facility on the railroad right-of-way, whose western portion is immediately upgradient of well PWS 68-1. The main characteristics of two facilities are as follows:

- The former CCC/USDA grain storage facility at the southern edge of the village operated 2 Quonsets and 15 bins with an estimated storage capacity of 128,970 bushels in 1950-1974. This facility is considered to lie within the general wellhead protection area defined by the NDEQ WHP Program, even though it is not hydraulically upgradient from the groundwater contamination in the Quaternary aquifer identified at well PWS 68-1 under either ambient or pumping conditions. Since 1974, the former CCC/USDA grain storage facility has been operated by Hubert, Farmers Coop, Coop Grain and Supply Company, Agri Coop, and CHS, Inc.

- The private grain facility along the railroad right-of-way operated 3 elevators, 1 Quonset, and 8 silos with an estimate capacity of more than 500,000 bushels during its peak time. The west part of the facility is immediately upgradient of well PWS 68-1 under both ambient and pumping conditions, as defined by the NDEQ WHP Program. Since 1938, the facility has been owned and operated by farmers and coops including McNeil, Bladen Grain Company, Coop Grain and Supply Company, Agri Coop, and CHS, Inc. 
TABLE 2.1 Analytical results for groundwater samples collected from the public water supply system at Bladena

\begin{tabular}{|c|c|c|c|c|c|}
\hline \multirow[b]{2}{*}{ Location } & & & \multirow[b]{2}{*}{$\begin{array}{l}\text { Laboratory } \\
\text { Sample }\end{array}$} & \multicolumn{2}{|c|}{ Concentration $(\mu \mathrm{g} / \mathrm{L})$} \\
\hline & \multicolumn{2}{|c|}{$\begin{array}{c}\text { Sampling } \\
\text { Date and Time }\end{array}$} & & $\begin{array}{c}\text { Carbon } \\
\text { Tetrachloride }\end{array}$ & Chloroform \\
\hline PWS 2006-1 & $7 / 30 / 2012$ & $13: 30$ & 186423 & $\mathrm{ND}^{\mathrm{b}}(0.5)$ & ND (0.5) \\
\hline PWS 2006-1 & $9 / 14 / 2009$ & & P36612-9 & ND $(0.5)$ & ND (0.5) \\
\hline PWS 68-1 & $7 / 22 / 2013$ & $10: 35$ & 246486 & 3.09 & ND (0.5) \\
\hline PWS 68-1 & $7 / 23 / 2012$ & $13: 10$ & 184554 & 2.99 & ND (0.5) \\
\hline PWS 68-1 & $7 / 18 / 2011$ & $14: 00$ & 118104 & 3.32 & ND (0.5) \\
\hline PWS 68-1 & $7 / 6 / 2010$ & $14: 35$ & 31430 & ND (0.5) & ND (0.5) \\
\hline PWS 68-1 & $7 / 20 / 2009$ & & P36764-3 & 3.83 & ND (0.5) \\
\hline PWS 68-1 & $7 / 28 / 2008$ & & P34724-1 & ND $(0.5)$ & ND (0.5) \\
\hline PWS 68-1 & $7 / 14 / 2008$ & & P34394-9 & 3.7 & ND (0.5) \\
\hline PWS 68-1 & 8/8/2005 & & P28022-9 & ND (0.5) & 4.3 \\
\hline PWS 68-1 & $8 / 17 / 2002$ & & P20930-13 & ND (0.5) & ND (0.5) \\
\hline PWS 68-1 & $2 / 29 / 2000$ & & P9423-13 & 0.47 & ND (0.4) \\
\hline Point of Entry & $1 / 7 / 1997$ & & 15791083 & ND (0.4) & ND (0.1) \\
\hline Point of Entry & $8 / 17 / 1993$ & & $6887 \mathrm{~V}$ & ND (0.4) & ND (0.1) \\
\hline Point of Entry & 4/1/1991 & & 15190721 & ND (0.4) & ND (0.1) \\
\hline Point of Entry & $7 / 25 / 1990$ & & 15090697 & ND $(0.4)$ & ND $(0.1)$ \\
\hline$N G^{c}$ & 6/5/1985 & & 1559221 & ND (0.4) & ND (0.1) \\
\hline
\end{tabular}

a Source of data: NDHHS (2014).

b ND, not detected at the indicated method detection limit.

c Location not defined further in source table. 
TABLE 2.2 Analytical results for groundwater samples collected from private wells in the vicinity of Bladen.

\begin{tabular}{|c|c|c|c|c|c|c|c|}
\hline \multirow[b]{2}{*}{ Location } & \multirow[b]{2}{*}{ Sample } & \multirow[b]{2}{*}{$\begin{array}{c}\text { Sample } \\
\text { Date }\end{array}$} & \multirow[b]{2}{*}{$\begin{array}{l}\text { Screen } \\
\text { Interval } \\
\text { (ft BGL) }\end{array}$} & \multicolumn{4}{|c|}{ Concentration $(\mu \mathrm{g} / \mathrm{L})$} \\
\hline & & & & $\begin{array}{c}\text { Carbon } \\
\text { Tetrachloride }\end{array}$ & Chloroform & $\begin{array}{l}\text { Methylene } \\
\text { Chloride }\end{array}$ & $\begin{array}{l}\text { Method } \\
\text { Detection } \\
\text { Limit }\end{array}$ \\
\hline \multicolumn{8}{|c|}{ Private well sampling in November 1997 by Woodward Clyde } \\
\hline KARR & BDDW01 & $11 / 26 / 97$ & - & NDa & ND & $N A^{b}$ & 0.5 \\
\hline MORIARTY & BDDW02 & $11 / 26 / 97$ & - & ND & ND & NA & 0.5 \\
\hline \multicolumn{8}{|c|}{ Private well sampling in September 2012 by Argonne } \\
\hline KAUFMAN & BLKAUFMAN-W-34824 & $9 / 21 / 12$ & - & ND & ND & ND & 1 \\
\hline KARR & BLKARR-W-34825 & $9 / 21 / 12$ & - & ND & ND & ND & 1 \\
\hline MORIARTY & BLMORIARTY-W-34826 & $9 / 21 / 12$ & - & ND & ND & ND & 1 \\
\hline KAUFMAN & BLKAUFMANLIVESTOCK-W- & $9 / 21 / 12$ & - & ND & ND & ND & 1 \\
\hline LIVESTOCK & 34827 & & & & & & \\
\hline NIEMEYER & BLNIEMEYER-W-34828 & $9 / 21 / 12$ & - & ND & ND & ND & 1 \\
\hline QC & BLQCTB-W-34829 & $9 / 21 / 12$ & - & ND & ND & ND & 1 \\
\hline
\end{tabular}

a ND, compound analyzed for but not detected at a level greater than or equal to the indicated method detection limit.

b NA, compound not analyzed for during sample analysis. 
TABLE 2.3 Documented transactions and activities for the former CCC/USDA property (currently owned by CHS, Inc.) at Bladen, Nebraska.

\begin{tabular}{|c|c|c|c|c|c|}
\hline $\begin{array}{l}\text { Document } \\
\text { Date }\end{array}$ & Lease Length & Grantor/Lessor & Grantee/Lessee & Description & Record \\
\hline $4 / 5 / 1950$ & 4/5/1950-4/5/1955 & R.C. Humes & $\mathrm{CCC}$ & $\begin{array}{l}\text { Original lease for approximately } \\
3 \text { acres }\end{array}$ & Book N, pp. 255-256 \\
\hline $7 / 20 / 1954$ & 4/5/1955-4/5/1960 & R.C. Humes & $\mathrm{CCC}$ & Lease extension for $5 \mathrm{yr}$ & Book N, pp. 657-658 \\
\hline $11 / 4 / 1957$ & NA & R.C. and Nora Humes & Arthur and Stella Morey & $\begin{array}{l}\text { Warranty deed for } 9.2 \text { acres, } \\
\text { including the CCC-leased property }\end{array}$ & Book 32, p. 210 \\
\hline $5 / 28 / 1958$ & NA & Arthur and Stella Morey & Carl and Erva Hubert & $\begin{array}{l}\text { Warranty deed for } 9.2 \text { acres, } \\
\text { including the CCC-leased property }\end{array}$ & Book 32, p. 253 \\
\hline 2/1/1960 & 4/5/1960-4/5/1970 & Carl and Erva Hubert & $\mathrm{CCC}$ & Lease extension for $10 \mathrm{yr}$ & Book P, pp. 566-567 \\
\hline 3/3/1969 & 4/1/1969-3/31/1979 & Carl and Erva Hubert & $\mathrm{CCC}$ & Lease extension for $10 \mathrm{yr}$ & Book 65, pp. 824-825 \\
\hline $8 / 13 / 1974$ & NA & Carl and Erva Hubert & $\mathrm{CCC}$ & $\begin{array}{l}\text { Lease termination effective on } \\
8 / 28 / 1974\end{array}$ & Book 73, pp. 654-657 \\
\hline 6/30/1978 & NA & Carl and Erva Hubert & Farmers Coop & Warranty deed (?) & Book 78, p. 1114 \\
\hline $7 / 21 / 1980$ & NA & Farmers Coop & $\begin{array}{l}\text { Coop Grain and Supply } \\
\text { Co., Roseland, Nebraska }\end{array}$ & Warranty deed & Book 80, p. 922 \\
\hline 7/1/1995 & NA & $\begin{array}{l}\text { Coop Grain \& Supply } \\
\text { Co., Roseland, NE }\end{array}$ & Agri Coop & Warranty deed & Book 95, p. 943 \\
\hline $7 / 8 / 2009$ & NA & Agri Coop & $\begin{array}{l}\text { CHS Holdrege, Inc. } \\
\text { (CHS, Inc.) }\end{array}$ & Merger & Book 09, p. 1531 \\
\hline
\end{tabular}




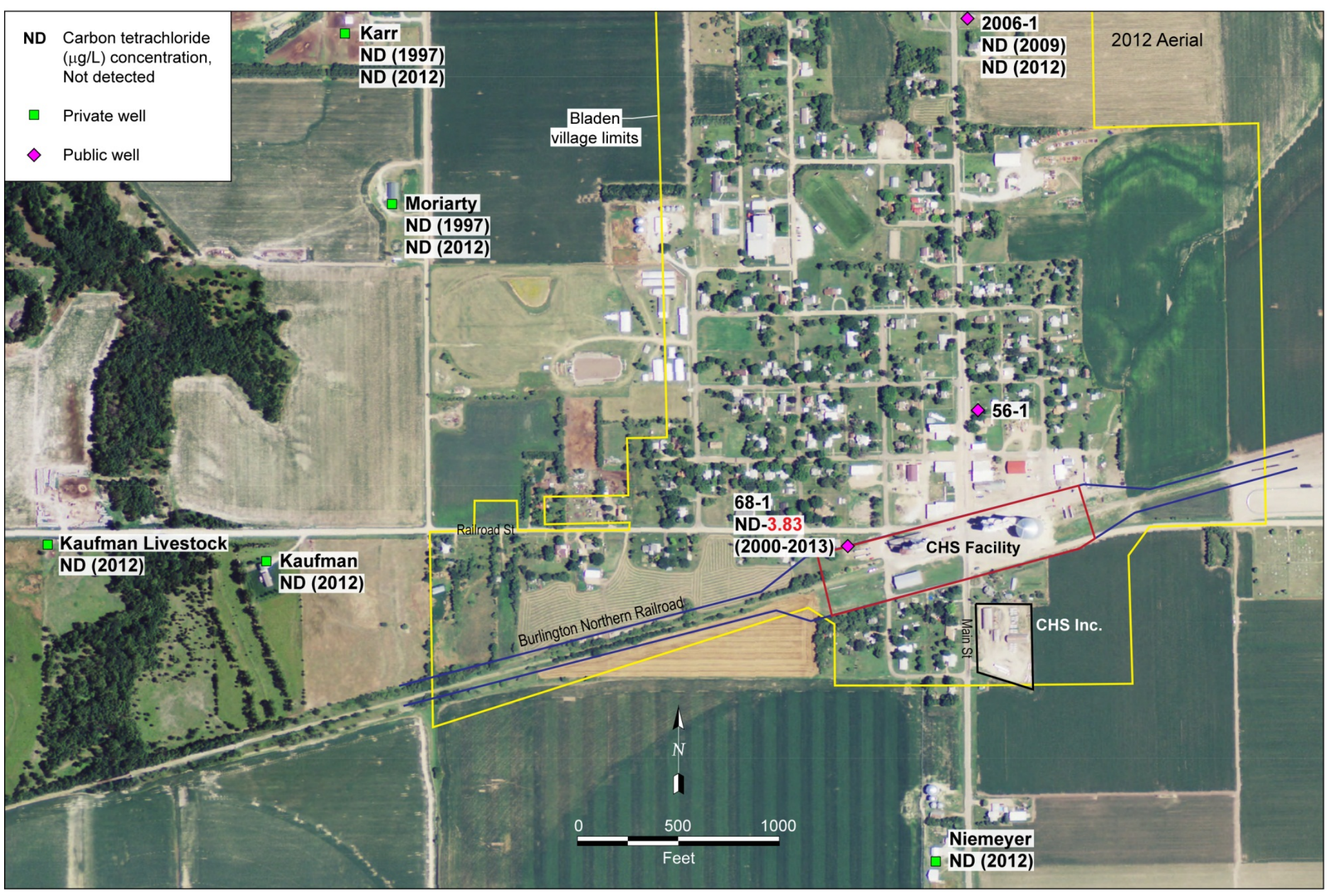

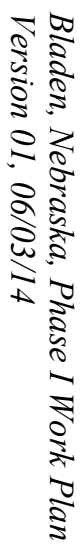

FIGURE 2.1 Historical carbon tetrachloride concentrations in groundwater samples collected from private wells by Woodward Clyde for the CCC/USDA in November 1997 and by Argonne for the CCC/USDA in July 2012. Source of photograph: NAIP (2012). 


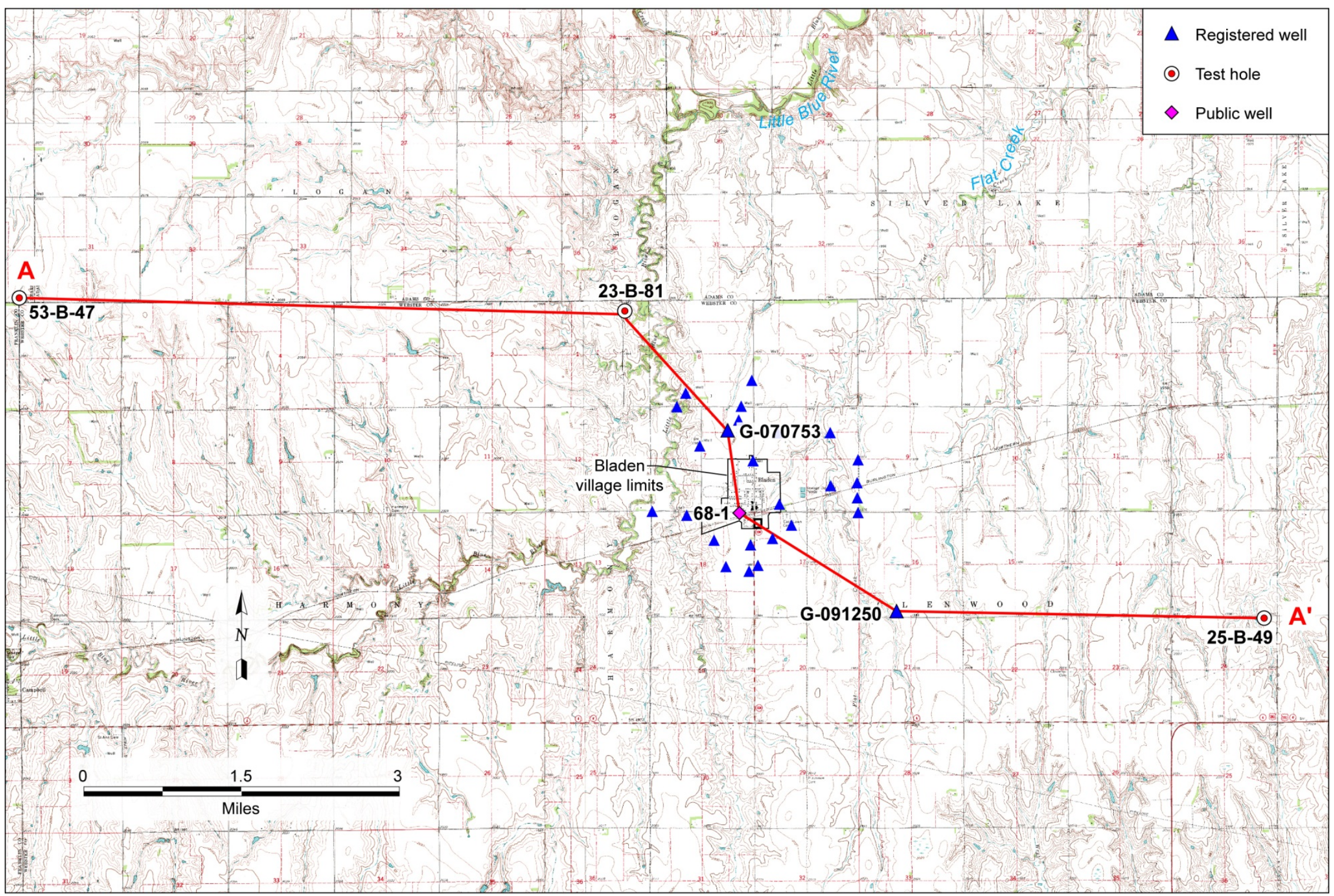

FIGURE 2.2 Locations of water wells within $1 \mathrm{mi}$ of the former CCC/USDA facility that have been registered with the state and nearby state geologic test holes, with the location of geologic cross section A-A'. Source of topographic map: USGS (1997). 


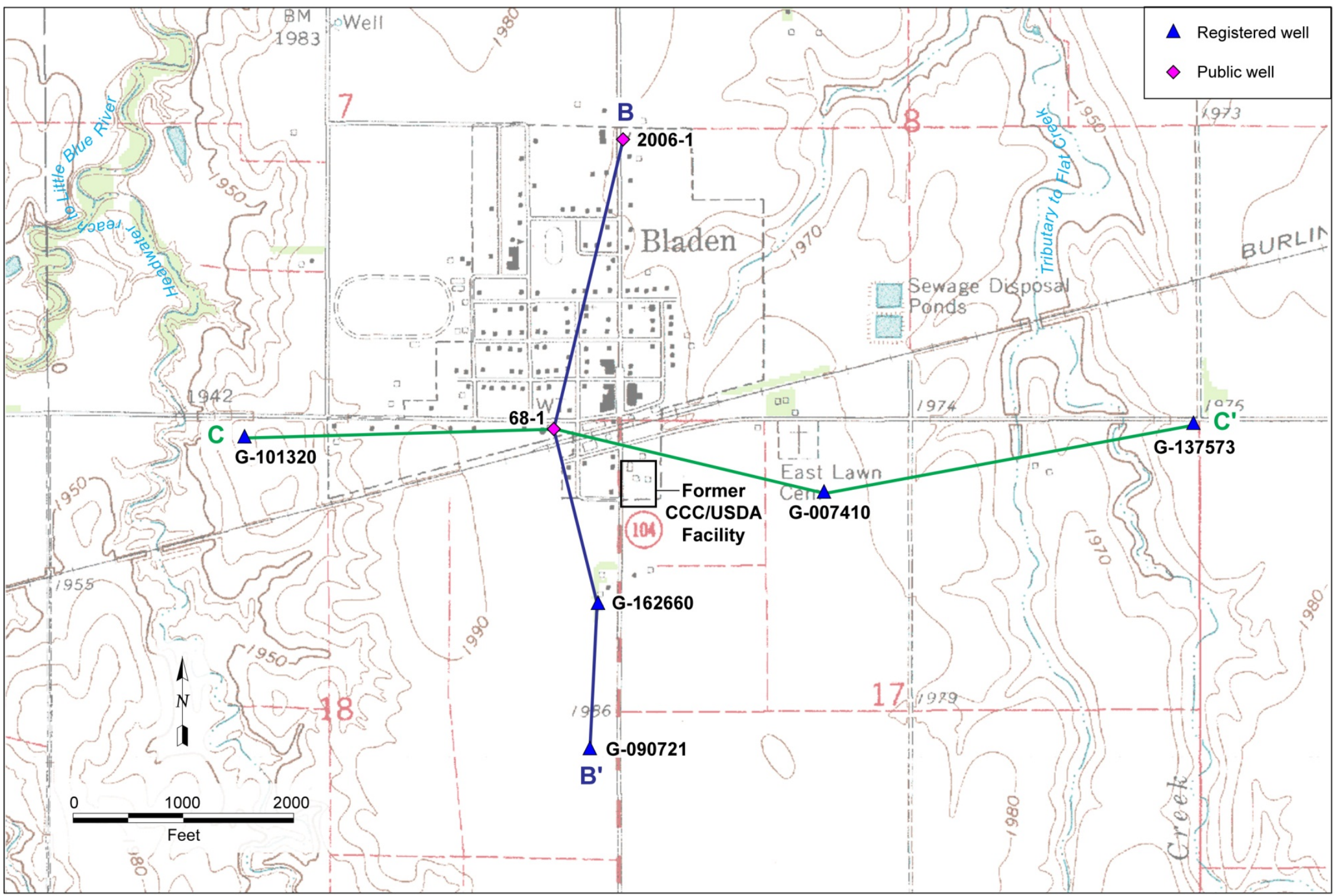

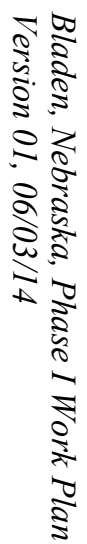

FIGURE 2.3 Locations of geologic cross sections B-B' and C-C' and the selected water wells used to construct the cross sections. Source of topographic map: USGS (1997). 


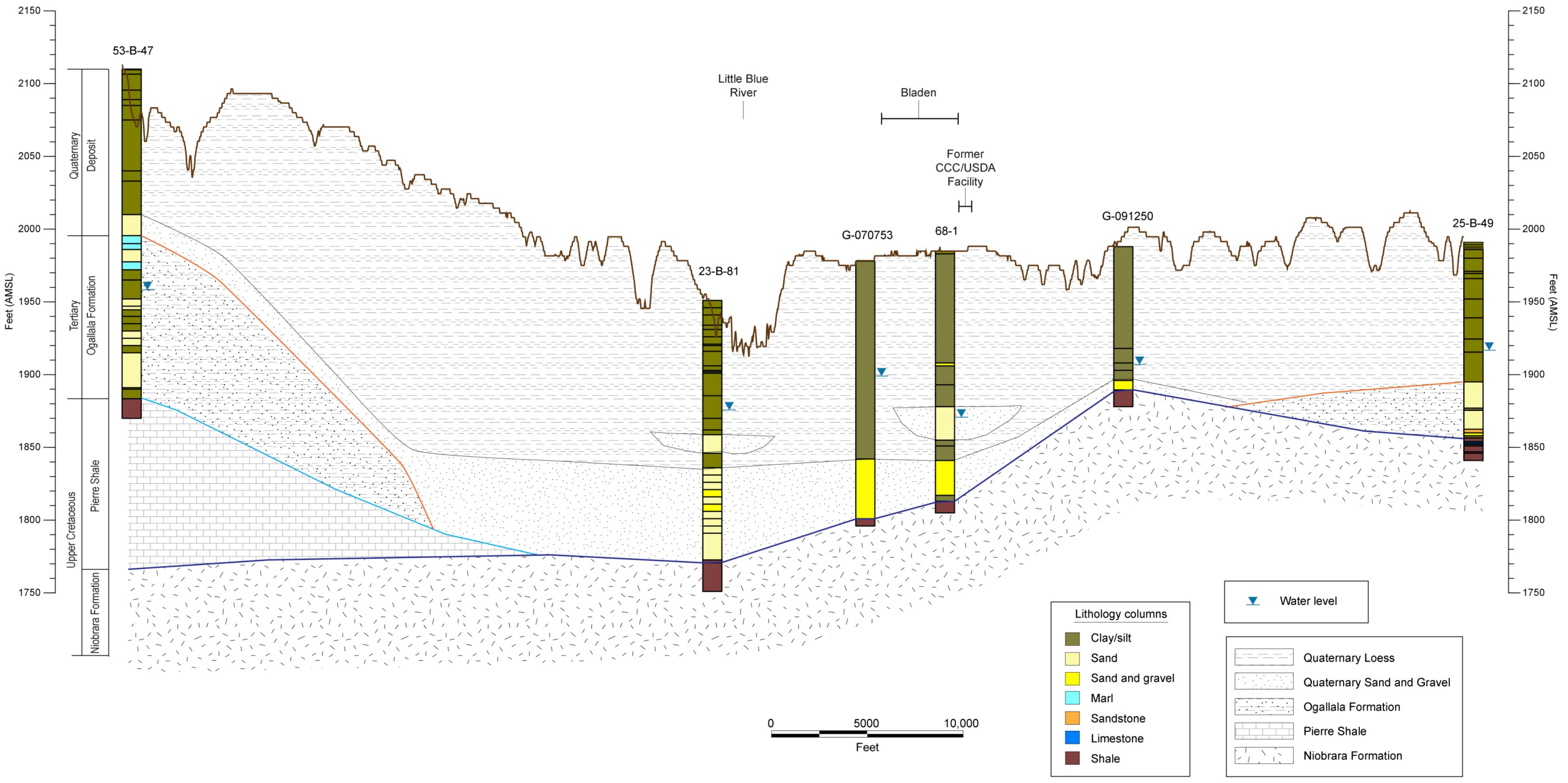




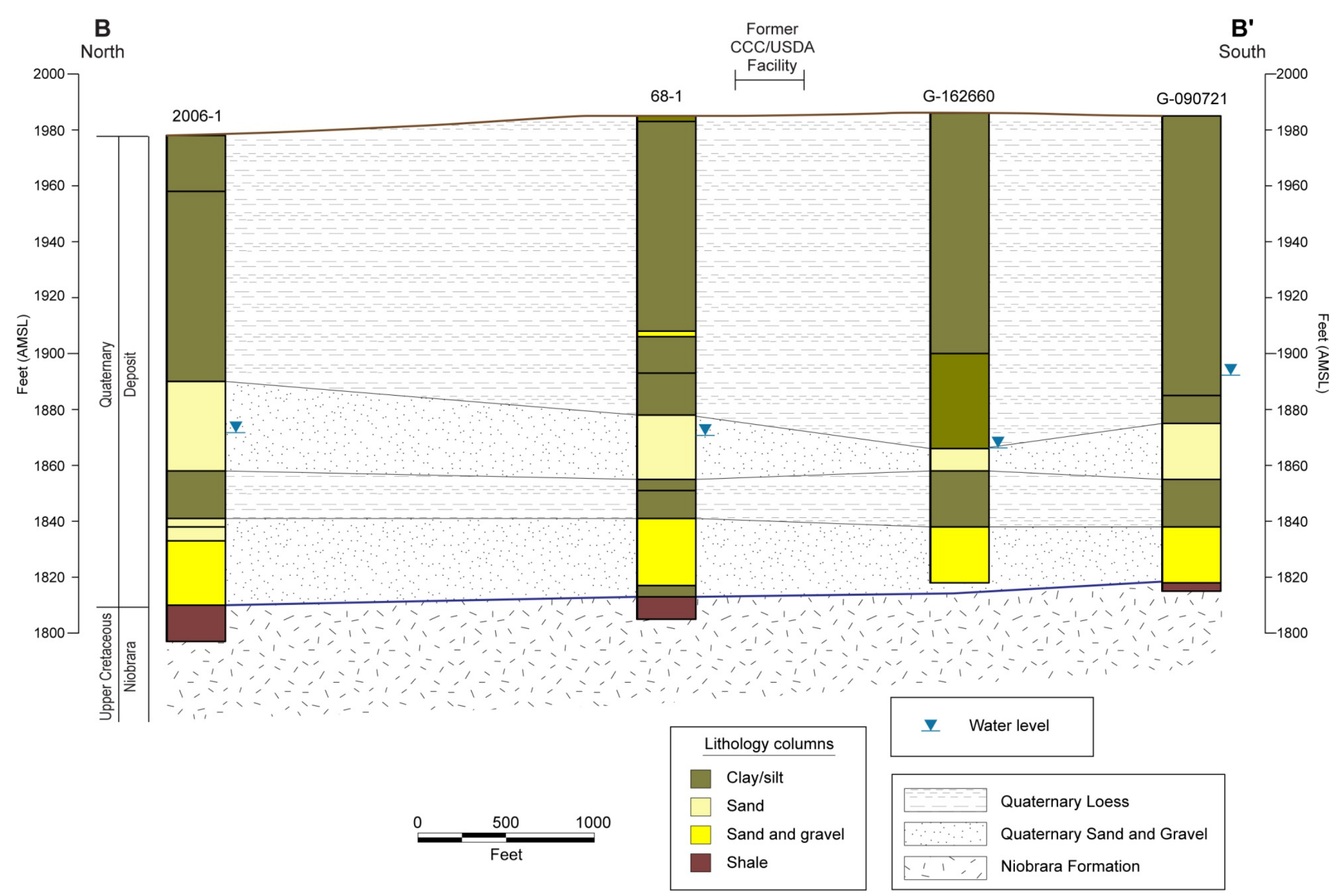

FIGURE 2.5 North-to-south geologic cross section B-B', illustrating local stratigraphic relationships and water levels at Bladen. 


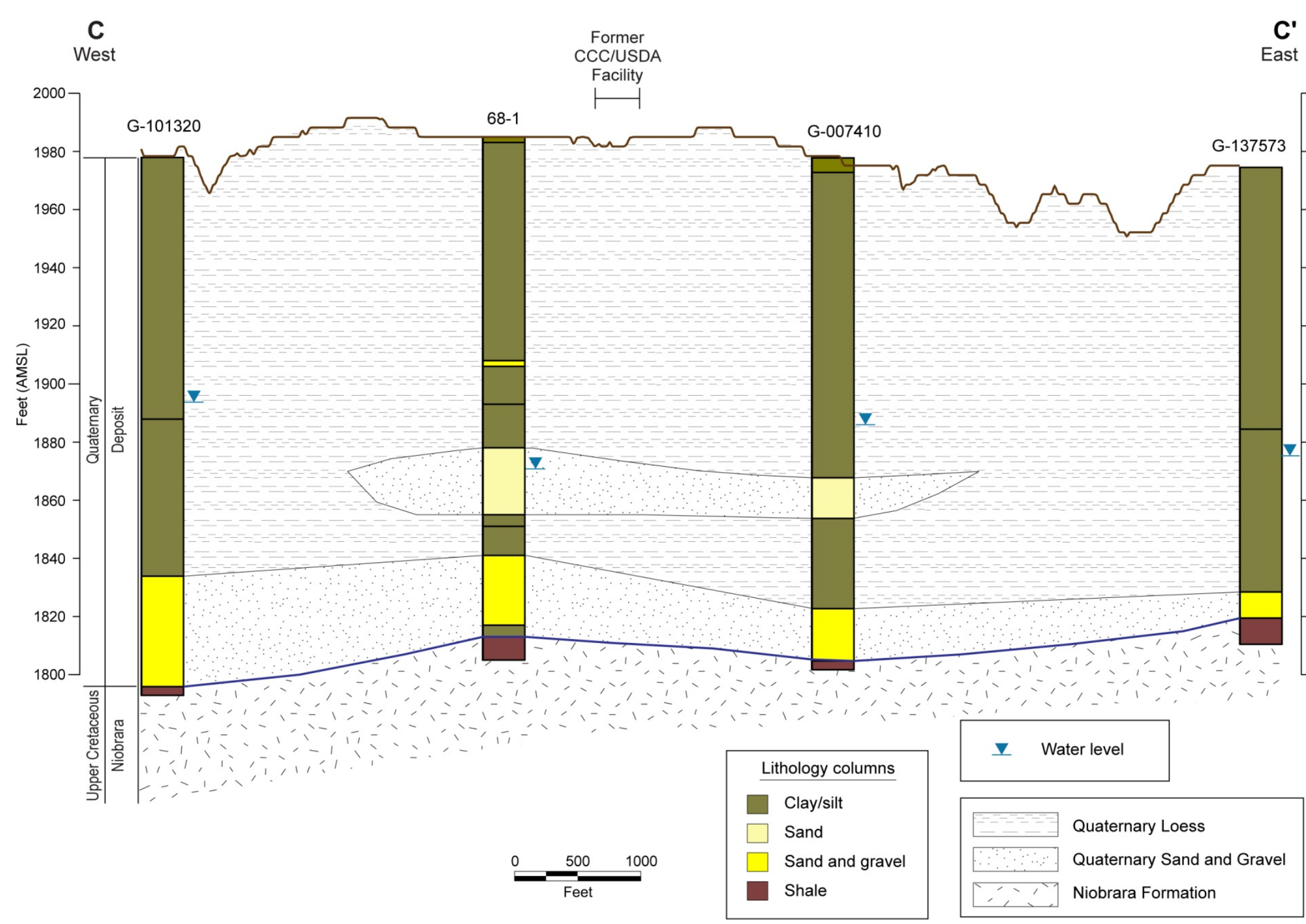

FIGURE 2.6 West-to-east geologic cross section C-C', illustrating local stratigraphic relationships and water levels at Bladen. 

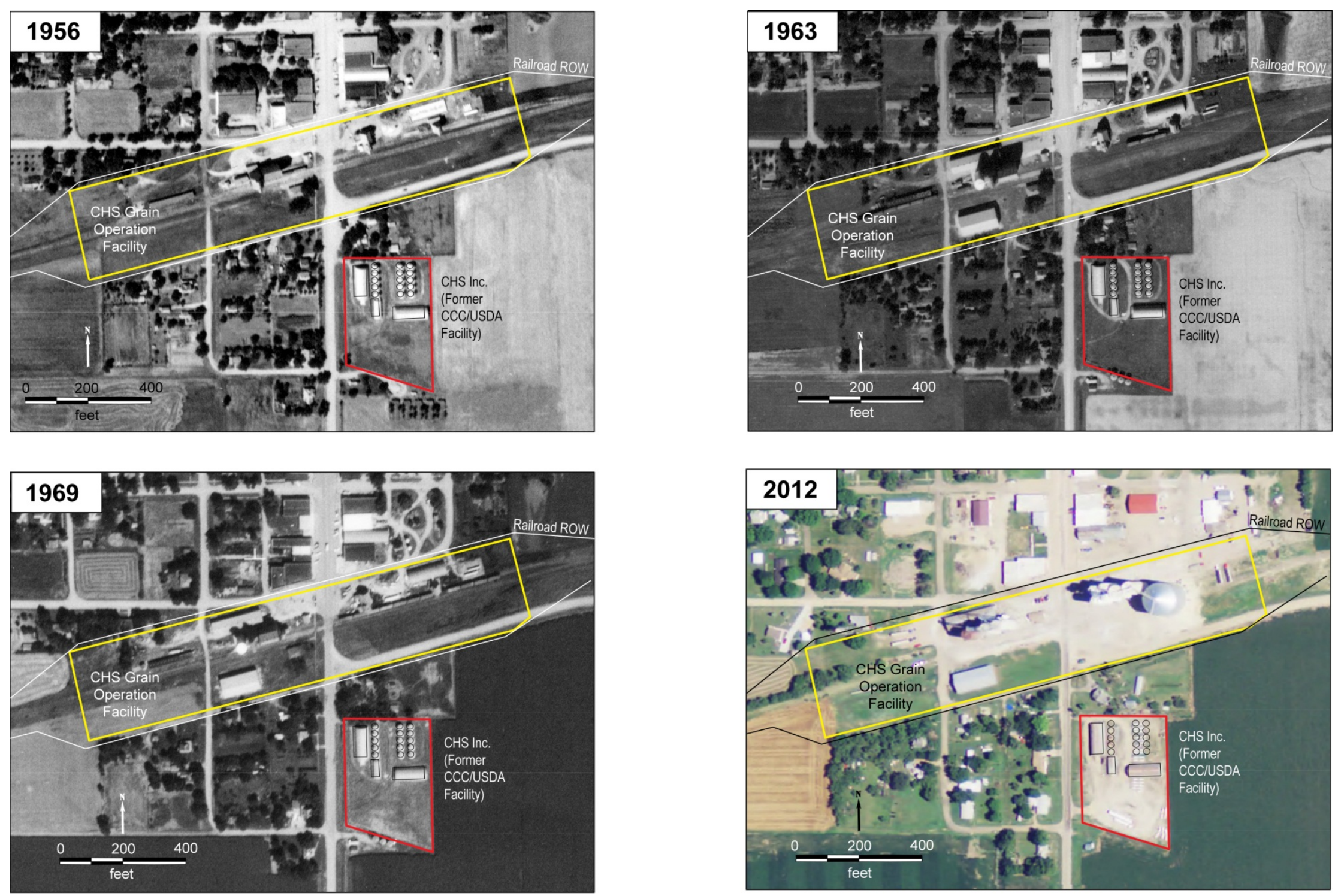

FIGURE 2.7 HIstorical and recent aerial photographs $(1956,1963,1969,2012)$, showing grain storage structures on the former CCC/USDA grain storage facility near the southern edge of Bladen and private grain operation facilities along the railroad right-of-way. Sources of photographs: USDA (1956, 1963, 1969); NAIP (2012). 

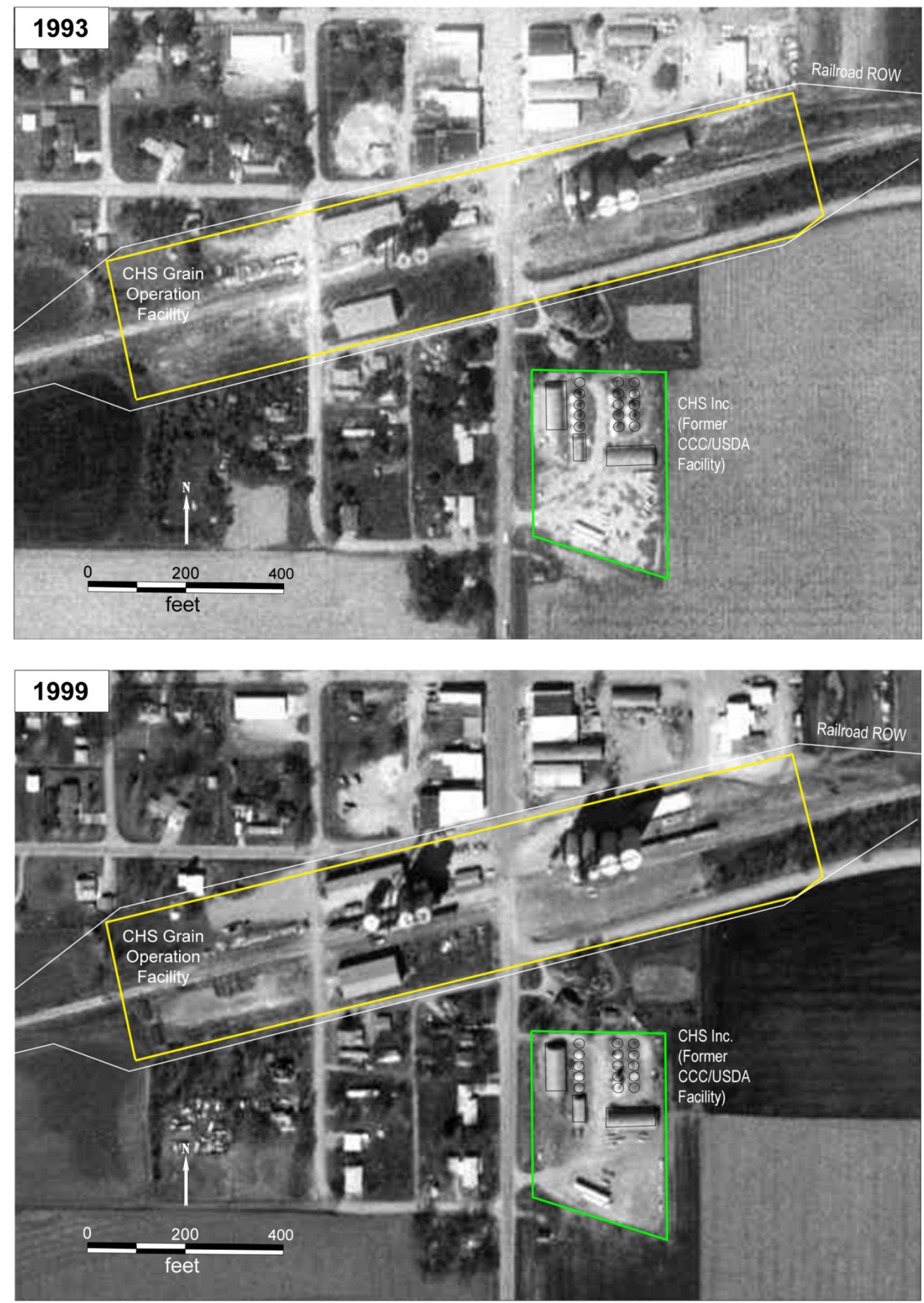

FIGURE 2.8 HIstorical aerial photographs (1993 and 1999), showing grain storage structures on the former CCC/USDA grain storage facility near the southern edge of Bladen and private grain operation facilities along the railroad right-of-way. Sources of photographs: DNR $(1993,1999)$. 


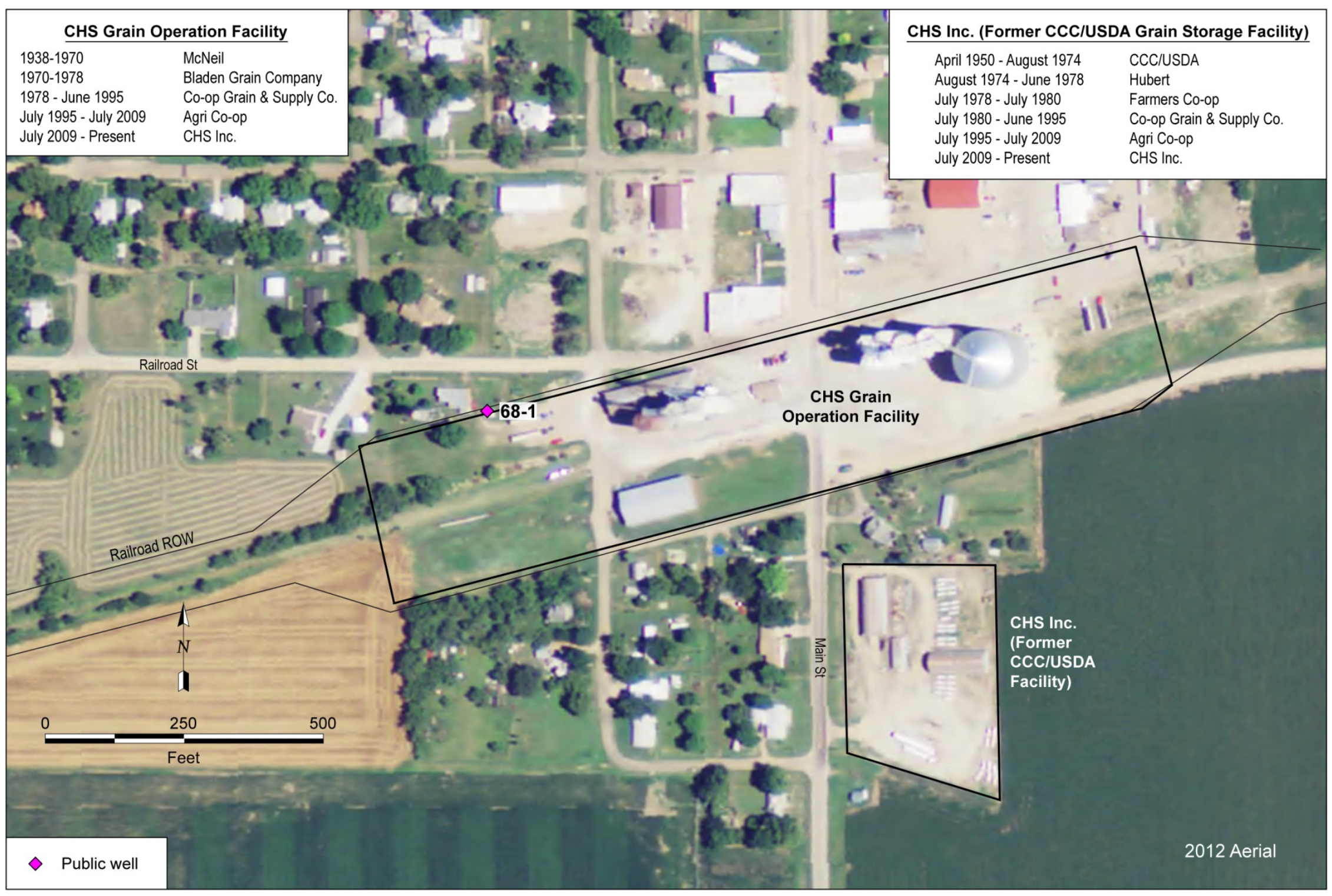

FIGURE 2.9 Locations and ownership of properties related to grain storage operations at Bladen, interpreted from property records, local community information, and aerial photographs. Source of photograph: NAIP (2012). 


\section{Proposed Technical Program for the Phase I Investigation}

The investigative program outlined here focuses on the potential relationship of the past grain storage activities at the former CCC/USDA facility at Bladen to the carbon tetrachloride contamination found in well PWS 68-1, approximately $700 \mathrm{ft}$ northwest of the former CCC/USDA facility. A phased approach is proposed to optimize the field investigation by incorporating new results from each previous phase, as well as input from the CCC/USDA and NDEQ project managers. The goal of the proposed program is to identify and characterize any subsurface contamination associated with the former CCC/USDA facility and its potential contributions to the groundwater contamination in well PWS 68-1, as well as to generate data for estimation of potential risks to human health and the environment. This section presents the technical objectives and tasks for the Phase I investigation.

\subsection{Technical Objectives of the Phase I Investigation}

The proposed technical objectives for the Phase I investigation are as follows:

- Determine the presence of a potential soil source of carbon tetrachloride and its daughter products in the vadose zone beneath the former CCC/USDA facility.

- Characterize the site-specific geology and hydrogeology at the former CCC/USDA facility.

- Delineate the distribution of carbon tetrachloride and its daughter products in groundwater at the former CCC/USDA facility.

- If contamination in groundwater is confirmed, obtain information on groundwater flow patterns that affect potential off-site contaminant migration from the former CCC/USDA facility. 


\subsection{Phase I Investigation Tasks}

To address the technical objectives in Section 3.1, the investigative activities (four tasks) discussed below are recommended for the Phase I program. Tasks 1-2 will be undertaken on the former CCC/USDA property. Data collected in Tasks 1-2 will be evaluated to determine whether implementation of the subsequent tasks is necessary. If groundwater contamination in the Quaternary aquifer is confirmed beneath the former CCC/USDA facility, Tasks 3-4 will be performed along the property boundaries of the former facility to delineate the extent of groundwater contamination and assess the potential for off-site migration. The tasks discussed below are summarized in Table 3.1. Site-specific elements of the investigative approach and methods for implementing the proposed investigation program are discussed in Section 4.

\subsubsection{Task 1: Determine the Presence of a Potential Soil Source of Carbon Tetrachloride and Its Daughter Products in the Vadose Zone beneath the Former CCC/USDA Facility}

A complete review of all publicly available documents from previous investigations (Section 2) indicated that no investigation has been conducted on the former CCC/USDA facility. To identify possible evidence of a soil source in the vadose zone beneath the former CCC/USDA facility, we propose three activities: (1) initial sampling of shallow soils at locations surrounding grain storage structures; (2) soil gas sampling beneath the Quonsets on the former property; and (3) targeted sampling of deeper soils (above the saturated zone) and groundwater at the top of the saturated zone at locations selected on the basis of the findings for the shallow soils. Samples of shallow soils will be collected by using a cone penetrometer (CPT) or other direct-push technique, while samples of deeper soils will be collected with the CPT or with a sonic drilling rig if necessary. Sampling will be performed according to methods specified in Section 4.

\subsubsection{Task 1a: Shallow Soil Sampling}

The initial shallow soil sampling is designed to screen for residual fumigant-related contaminants in shallow soils as an indicator of possible historical surface release of fumigant, as well as potential contamination of underlying deeper soil and potential pathways for contaminant migration from shallow soil to groundwater. Previous Argonne work (Alvarado and Rose 2004) demonstrated that the analysis of shallow soils for carbon tetrachloride and its daughter products 
(chloroform and methylene chloride) by a headspace method can serve as a screening tool to identify possible soil contamination in underlying deeper soils and groundwater. The headspace data are not used quantitatively but are examined for contaminant distribution patterns, in order to prioritize areas for follow-up sampling and analysis of deeper soils and underlying groundwater. The shallow soils will also be analyzed by a purge-and-trap method with analysis by gas-chromatography-mass spectrometry (GC-MS) to identify potential health risks associated with direct exposure to the shallow soils.

The initial locations for shallow soil sampling will target former grain storage structures and driveways at the former CCC/USDA facility. These locations are expected to have been the most vulnerable to potential releases of carbon tetrachloride during grain storage and handling of fumigant containers or related equipment. On the basis of the operational setting of the former CCC/USDA facility, as shown in the 1956, 1963, and 1969 aerial photos (Figure 2.7), 10 locations for shallow soil sampling are recommended. Of these locations, 6 are among/around the former grain bins ( 2 in each row), 2 (to the south) are at/near the front entrances of the Quonsets, and 2 lie along the former driveway between the grain storage structures (Figure 3.1). The former CCC/USDA facility is currently owned by CHS, Inc., and operated for CHS agricultural services. These sampling locations might be adjusted during field implementation to minimize the impact on the business operation at the facility and/or to meet CHS requests.

The following activities are recommended for the initial survey of shallow soils at the former CCC/USDA facility (Task 1a):

- Vertical soil profiling will be performed at all survey locations. For each profile, soil samples will be collected at intervals of about $4 \mathrm{ft}$, from the surface to $28 \mathrm{ft}$ BGL (sampling depths of $2 \mathrm{ft}, 6 \mathrm{ft}, 10 \mathrm{ft}, 14 \mathrm{ft}, 18 \mathrm{ft}, 22 \mathrm{ft}$, and $26 \mathrm{ft} \mathrm{BGL}$ ), or at significant changes in the soil profile or recovery conditions.

- Analyses for VOCs with a headspace method will be conducted by the Applied Geosciences and Environmental Management (AGEM) Laboratory at Argonne on the second day for all shallow soil samples collected, to identify patterns of carbon tetrachloride, chloroform, and methylene chloride contamination in shallow soils and to determine sampling locations for deeper soils (Task 1c). 
- Analyses for VOCs with a purge-and-trap method will be conducted subsequently for all shallow soil samples to provide a quantitative basis for evaluating risk due to soil contamination.

\subsubsection{Task 1b: Soil Gas Sampling beneath Quonsets}

Soil gas sampling will be conducted in the shallow subsurface within the footprint of the existing Quonset structures, if access inside the structures is permitted. Two soil gas sampling points are proposed - one for each Quonset, in a central portion of the structure if possible. The exact locations will be determined with the owner's permission and to minimize impacts on business at the CHS facility. The major activities for soil gas sampling (Task 1b) include the following:

- Soil gas samples will be collected by a Geoprobe unit through a small borehole with a Post-Run Tubing (PRT) system, from the depth interval at 185-200 cm (roughly 6-7 ft BGL) and stored in metal, certified-clean, 1-L gas canisters.

- Soil gas samples collected in the 1-L canisters will be shipped to TestAmerica Laboratories, Inc., South Burlington, Vermont, for VOCs analysis (including carbon tetrachloride, chloroform, and methylene chloride) with EPA Method TO-15.

The results of soil gas sampling will determine the presence of contamination in soil gas and provide a basis for assessing the potential for upward vapor intrusion of VOCs contaminants from soil gas to present and future structures on the former $\mathrm{CCC} / \mathrm{USDA}$ property.

\subsubsection{Task 1c: Targeted Soil Sampling for the Deeper Soils and Groundwater Sampling at the Top of the Saturated Zone}

The contaminant distribution patterns in shallow soils at the former CCC/USDA facility will be evaluated to identify plausible pathways for contaminant migration to deeper soils and 
groundwater. Up to three locations with evidence of plausible pathways will be selected for sampling of deeper soils.

The activities proposed for sampling of deeper soils at the former CCC/USDA facility (Task 1c) are as follows:

- Vertical soil profiling will be performed at all selected locations targeting deeper soils with either the CPT or the sonic drilling rig. For each profile, soil samples will be collected at intervals of 5-10 ft, from a depth of $30 \mathrm{ft}$ BGL to the top of the saturated sand and gravel unit (Figures 2.5 and 2.6). The estimated depth of the saturated sand and gravel unit is approximately 100-120 ft BGL at the former CCC/USDA facility.

- All soil samples will be analyzed for carbon tetrachloride, chloroform, and methylene chloride with a purge-and-trap method.

- If the deep soil profiling is conducted with a CPT unit, CPT electronic logs will be collected and analyzed for general information on changes in lithology, to provide further guidance for confirmatory sampling at selected intervals. However, the depth of penetration could be a limiting factor in the use of the CPT for deeper soil sampling.

- Continuous cores will be collected and analyzed visually for lithologic evaluation and description. At selected intervals, soil property testing, grain size analysis, and other chemical analyses might be performed, as necessary, for the collected core samples.

- Groundwater samples will be collected for VOCs analysis from the top of the identified saturated sand and gravel unit at the base of deep soil boring.

The results of vertical soil profiling will provide a scientific basis for determining whether a soil source of carbon tetrachloride exists at the former CCC/USDA facility, as well as the potential for a soil-to-groundwater migration pathway. 


\subsubsection{Task 2: Characterize the Site-Specific Geology and Hydrogeology at the Former CCC/USDA Facility}

As discussed in Section 2.3, local geologic units expected to be penetrated at the former CCC/USDA facility, from top to bottom, are as follows: (1) a Quaternary undifferentiated loess unit (silt and clay); (2) a Quaternary sand and gravel unit; and (3) Upper Cretaceous Niobrara chalk, shale, and limestone (Figures 2.5 and 2.6). The local principal aquifer is the saturated Quaternary sand and gravel unit, which unconformably overlies the Cretaceous Niobrara bedrock. The thickness of the saturated sand and gravel might vary from $9 \mathrm{ft}$ to $38 \mathrm{ft}$ from one location to the other. To gain a better understanding of the local aquifer and assist in groundwater sampling, one deep boring for lithologic confirmation will be conducted at one of the deeper soil sampling locations, penetrating the entire aquifer unit to the top of the Niobrara. The location of this deep boring will be based on the results of the investigations described in Section 3.2.1, to target possible pathways for soil contamination to groundwater in the aquifer. The sonic drilling rig will be used to penetrate the deep horizons.

The recommended activities associated with the deep boring at the former CCC/USDA facility (Task 2) are follows:

- Continuous core will be collected to a depth of approximately $180 \mathrm{ft}$ BGL, at the top of Niobrara Formation bedrock. On the basis of the existing water well records in the vicinity of the former CCC/USDA facility, the stratigraphic units expected to be penetrated are (1) the Quaternary loess unit (about $110 \mathrm{ft}$ thick) and (2) the sand and gravel unit with a clay layer (50-60 ft thick). The core collected will be analyzed visually, and the lithology will be described. At selected intervals, soil property testing, grain size analysis, and other chemical analyses might be performed, as necessary, for the collected core samples.

- The information on lithology, soil properties, and water content and recovery collected from this deep boring (to approximately $180 \mathrm{ft}$ BGL) and other deeper soil sampling locations (up to $120 \mathrm{ft}$ BGL; Section 3.2.1.3) will be evaluated to determine the hydrostratigraphic sequence, including the confining layer, aquifer, and relatively more permeable intervals within the aquifer. The interpreted hydrogeologic sequence and its properties will guide the collection of groundwater samples in the subsequent task (Section 3.2.3). 


\subsubsection{Task 3: Delineate the Distribution of Carbon Tetrachloride and Its Daughter Products in Groundwater at the Former CCC/USDA Facility}

The results of groundwater sampling at selected deeper soil sampling points (Task 1c, Section 3.2.1.3) and the deep boring location for lithologic identification (Task 2, Section 3.2.2) will be evaluated to determine the presence of carbon tetrachloride and its daughter products in groundwater at the former $\mathrm{CCC} / \mathrm{USDA}$ facility. If groundwater contamination associated with fumigants is confirmed, a subsequent task will be performed to delineate the extent of contamination in groundwater. Additional groundwater sampling will target the Quaternary aquifer at the four locations shown in Figure 3.2. One sampling point in the southern part of the former facility is located upgradient from the grain storage structures, on the basis of estimated groundwater flow in the aquifer, and the other three sampling points are possibly downgradient locations along the edge of the former facility. These locations might be adjusted slightly, depending on the actual locations of groundwater sampling at three deep-soil sampling points (Task 1c).

The proposed activities for delineation of contamination in groundwater at the former CCC/USDA facility (Task 3 ) are as follows:

- Deep coring at four sampling points will be conducted through the entire section of aquifer to the top of Niobrara Formation chalk and shale at the approximate depth of $180 \mathrm{ft}$. Observations of lithology, grain size, thickness, and water recovery will be recorded for use in determining the characteristics of the aquifer and guiding the groundwater sampling.

- Groundwater samples will be collected from 1-2 intervals in the aquifer at each sampling location, identified by considering the aquifer thickness and the sampling results obtained in Tasks $1 \mathrm{c}$ and 2 . Each sampling interval will be in a range of 5-10 ft.

- All groundwater samples will be analyzed for VOCs to identify the presence and concentrations of carbon tetrachloride, chloroform, and methylene chloride. The analytical results will be evaluated to determine the lateral distribution of contamination in the aquifer. 


\subsubsection{Task 4: Obtain Information on the Groundwater Flow Patterns That Affect Potential Off-Site Contaminant Migration from the Former CCC/USDA Facility}

The water level data collected by the NDEQ WHP Program suggest that, under ambient conditions, groundwater in the principal aquifer generally flows toward the north-northeast in the regional area that encompasses the village of Bladen. However, the pumping at well PWS 68-1 and surrounding irrigation wells might alter the groundwater flow pattern locally. Information on the site-specific groundwater flow patterns and their variations in response to the local pumping events is critical for determining the potential for off-site contaminant migration beneath the former $\mathrm{CCC} / \mathrm{USDA}$ facility. Therefore, if the presence of groundwater contamination is identified beneath the former CCC/USDA facility (Sections 3.2.1 and 3.2.2), a preliminary groundwater monitoring network will be established during the Phase I investigation.

The proposed activities for determining groundwater flow patterns (Task 4) are as follows:

- Monitoring wells will be installed with a drilling rig at the deep boring location (described in Task 2, Section 3.2.2) and four groundwater sampling points (Task 3, Section 3.2.3; Figure 3.2). The well depth is expected to be approximately $180 \mathrm{ft} \mathrm{BGL}$. The screen interval will be selected on the basis of contaminant data obtained in Tasks 1c, 2, and 3. All wells will be completed in accordance with Nebraska regulations, Title 178 NAC 12.

- Groundwater levels will be measured in all wells at least $24 \mathrm{~h}$ after well completion (and after the wells have stabilized). The locations of all monitoring wells will be determined by a professional, licensed surveyor, in relation to state coordinates. The surveyor will determine the elevation of the top of each well and the designated reference point in each well for water level measurement.

- Groundwater level fluctuations will be monitored continuously over a period of 6-12 months. Automatic water level sensors and data loggers will be installed in all monitoring wells to identify the effects on the flow pattern of pumping at the public water supply and local irrigation wells and seasonal variations in the groundwater system. 
- Results of the investigation for soil and groundwater contamination at the former CCC/USDA facility generated from Tasks 1-3, together with the groundwater flow patterns and variations in response to pumping at the public water supply and local irrigation wells and seasonal variations identified in Task 4, will be compiled to determine the configuration of the contaminant plume and the primary direction(s) of groundwater flow and contaminant migration under the site-specific conditions in the vicinity of the former CCC/USDA facility. 
TABLE 3.1 Summary of Phase I investigation tasks.

\begin{tabular}{|c|c|c|c|c|c|c|c|c|}
\hline \multirow[b]{2}{*}{ Task } & \multirow[b]{2}{*}{ Objective } & \multirow[b]{2}{*}{ Medium } & \multirow[b]{2}{*}{ Depth (ft BGL) } & \multirow{2}{*}{$\begin{array}{l}\text { Number of } \\
\text { Locations }\end{array}$} & \multicolumn{2}{|c|}{ Equipment } & \multirow[b]{2}{*}{ Section } & \multirow[b]{2}{*}{ Figure } \\
\hline & & & & & CPT & Sonic Rig & & \\
\hline $1 \mathrm{a}$ & Shallow soil sampling & Soil profiles & $2,6,10,14,18,22,26$ & 10 & $x$ & - & 3.2.1.1 & 3.1 \\
\hline $1 \mathrm{~b}$ & Soil gas sampling & Soil gas & $6-7$ & 2 & Geoprobe & - & 3.2.1.2 & 3.1 \\
\hline $1 \mathrm{c}$ & Deeper soil sampling & Soil profiles ${ }^{a}$ & $\begin{array}{c}30 \text { to }<120 \\
\text { (to top of saturated } \\
\text { sand and gravel unit) }\end{array}$ & $\leq 3$ & $x$ & - & 3.2.1.3 & $3.1^{b}$ \\
\hline $1 \mathrm{c}$ & GW sampling & Groundwater & $\begin{array}{c}100-120 \\
\text { (top of saturated sand } \\
\text { and gravel unit) }\end{array}$ & $\leq 3$ & $x$ & - & 3.2.1.3 & $3.1^{b}$ \\
\hline 2 & $\begin{array}{l}\text { Site-specific } \\
\text { hydrostratigraphy }\end{array}$ & $\begin{array}{l}\text { Soil cores and } \\
\text { groundwaterc }\end{array}$ & $\begin{array}{c}180 \\
\text { (to Niobrara bedrock) }\end{array}$ & 1 & - & $x$ & 3.2 .2 & $3.1^{d}$ \\
\hline 3 & $\begin{array}{l}\text { Delineate extent of } \\
\text { groundwater contamination }\end{array}$ & $\begin{array}{l}\text { Soil cores and } \\
\text { groundwater }^{c}\end{array}$ & $\begin{array}{l}100-180 \text { (saturated } \\
\text { sand and gravel unit) }\end{array}$ & 4 & - & $x$ & 3.2 .3 & 3.2 \\
\hline 4 & Monitoring well installationd & Groundwater & 180 & $\sim 5$ & - & $x$ & 3.2 .4 & - \\
\hline
\end{tabular}

a Deep soil samples will be collected at 5-ft to $10-\mathrm{ft}$ intervals.

b Locations of deep soil and groundwater sampling (Task 1c) will be selected on the basis of results for 10 shallow soil sampling locations.

c Continuous coring, analysis of soil cores, and collection of groundwater samples from 1-2 intervals in aquifer (saturated sand and gravel unit).

d Location will be selected from 1 of 3 deep soil sampling locations on basis of the results of Task 1c. 


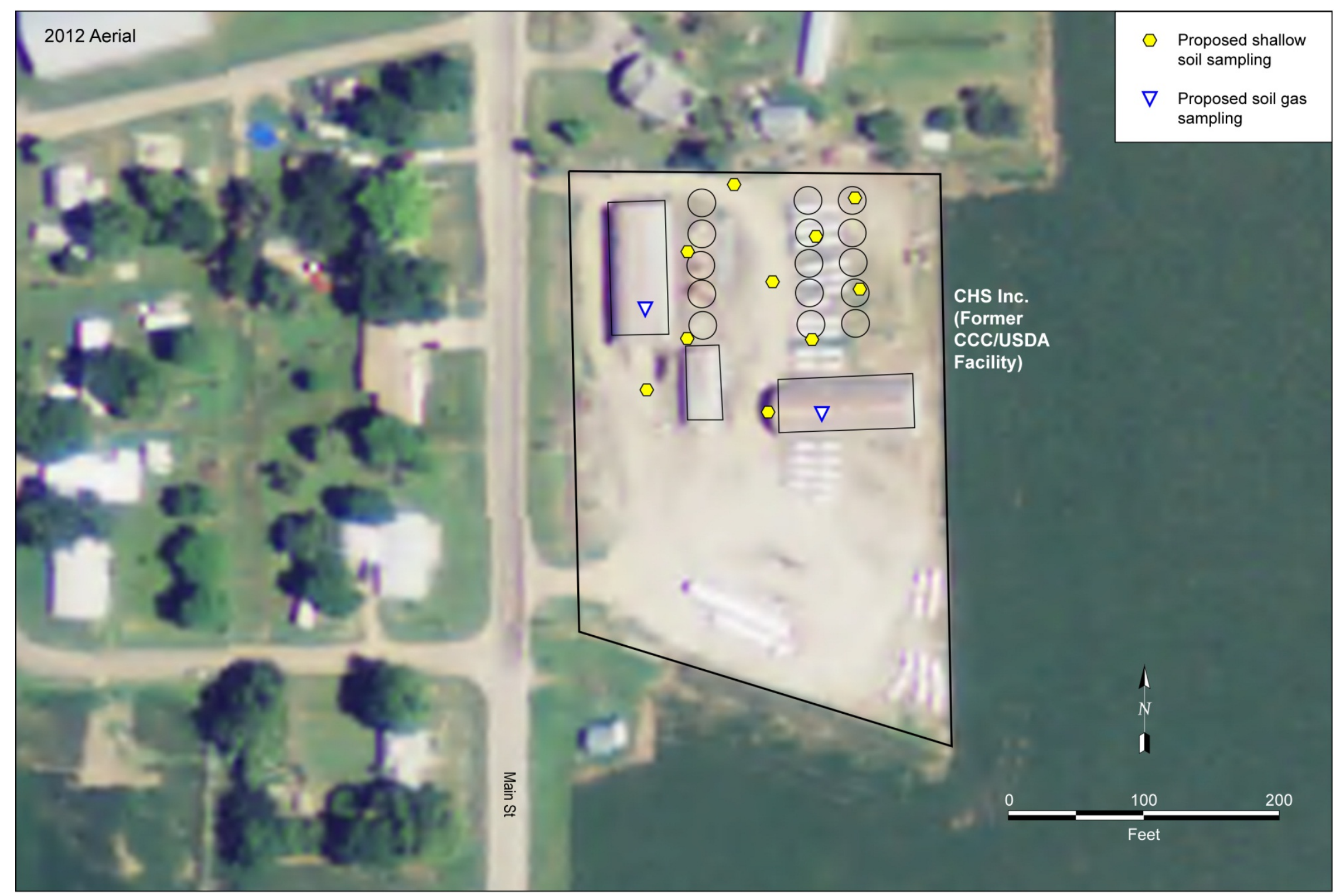

FIGURE 3.1 Proposed shallow soil sampling locations on the former CCC/USDA property (currently CHS property). Source of photograph: NAIP (2012). 


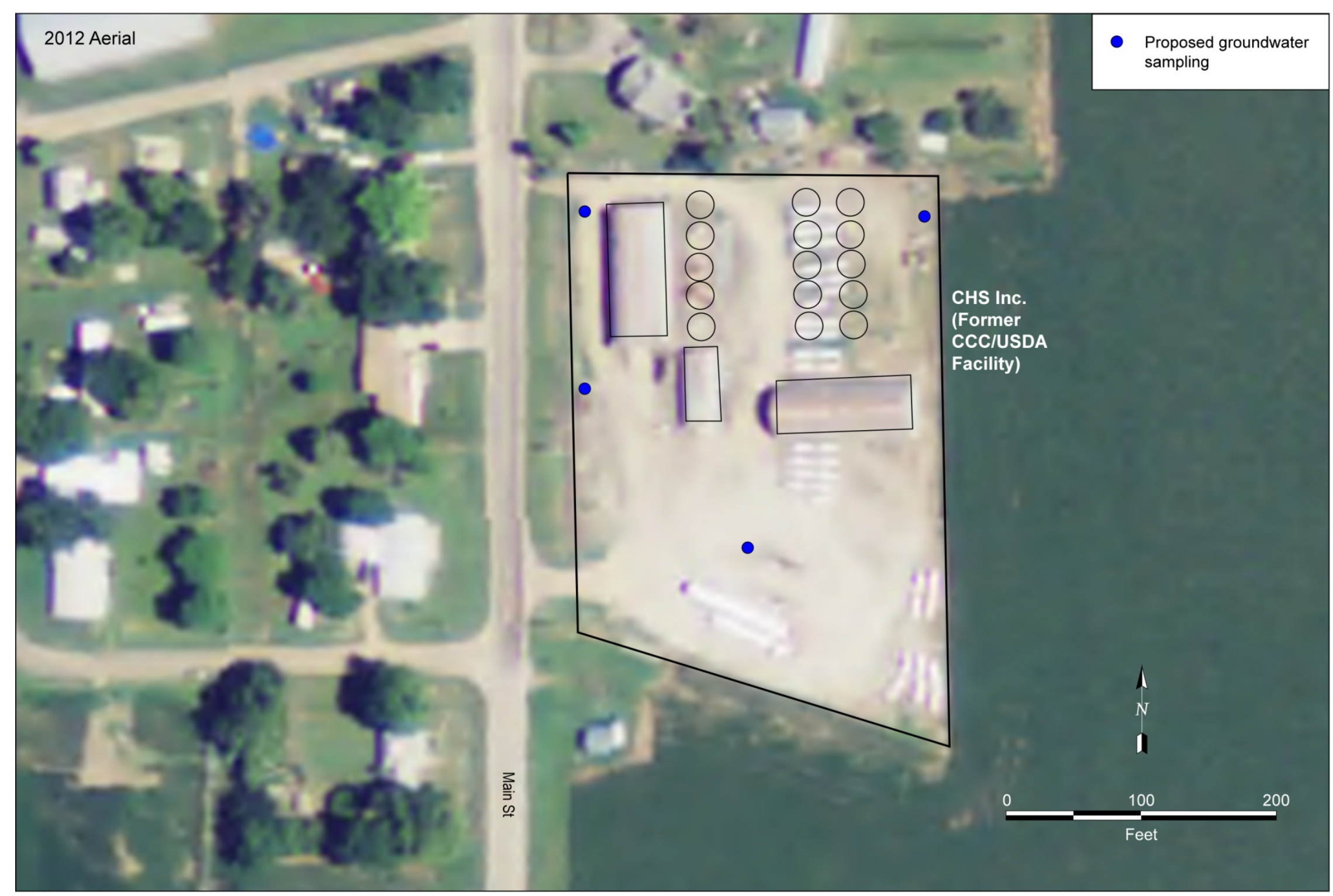

FIGURE 3.2 Proposed groundwater sampling locations on the former CCC/USDA property (currently CHS property). Source of photograph: NAIP (2012). 


\section{Investigation Methods}

The site-specific investigative technologies, field procedures, and analytical methods to address the technical objectives discussed in Section 3 are discussed below. Argonne will implement the proposed tasks in accord with established standard operating procedures, relevant state regulations, quality assurance-quality control (QA/QC) measures, and general health and safety policies.

\subsection{Methods for Shallow Soil Sampling and Analysis}

Shallow soil sampling (Section 3.2.1.1) will be performed by using the Argonne 22-ton, track-mounted CPT crawler. At each investigation location, a 4-ft-long core barrel with a 1.125-in.-I.D. disposable liner (Geoprobe dual-tube coring system) will be advanced with the CPT unit to collect samples of shallow soils at anticipated depths of $2 \mathrm{ft}, 6 \mathrm{ft}, 10 \mathrm{ft}, 14 \mathrm{ft}, 18 \mathrm{ft}$, $22 \mathrm{ft}$, and $26 \mathrm{ft}$ BGL.

The soil samples recovered from the core barrel will be placed immediately in jars, then sealed, placed in coolers with dry ice at $-78.5^{\circ} \mathrm{C}$ for overnight shipment to the AGEM Laboratory for rapid-turnaround analysis. The premise of using dry ice is that VOCs are volatile at room temperature, but their volatility decreases as the temperature decreases. For example, the vapor pressure of carbon tetrachloride decreases by four orders of magnitude when the temperature changes from $15.8^{\circ} \mathrm{C}$ to $-79.4^{\circ} \mathrm{C}$ (CRC 1999-2000). In previous work evaluating the recoveries of soil samples collected and stored on dry ice, we demonstrated that storage with dry ice is a better option than traditional procedures (Alvarado and Rose 2004).

The shallow soil samples will be analyzed first by a headspace method with a gas chromatograph and electron capture detector (modified EPA Method 5021). The headspace method (Alvarado and Rose 2004) provides an improved, rapid analytical process that is sensitive to low concentrations. The results from the headspace analysis can be used qualitatively to facilitate initial screening to guide subsequent field activities. At a later time, all soil samples will be further subjected to purge-and-trap sample preparation with analysis by GC-MS (EPA Methods 5030B and 8260B) for VOCs. The results of the purge-and-trap analysis will be used as a quantitative base for risk assessment. 


\subsection{Methods for Soil Gas Sampling and Analysis}

Sub-slab soil gas samples will be collected from the Quonsets on the former CCC/USDA facility by using a Geoprobe $5400 \mathrm{M}$ unit, equipped with a 2 -in. cement bit, to drill a 2 -in. hole through the cement floor. A PRT soil gas sampling system will be installed on the Geoprobe $5400 \mathrm{M}$, with an expandable point holder attached to the lead rod of the Geoprobe rod string, and the rod will be advanced to $7 \mathrm{ft}(215 \mathrm{~cm})$ BGL. A 0.25 -in. poly tubing fitted with a left-handthreaded adapter will be lowered into the rod string and threaded onto the expandable PRT tip. A second open-end 0.25 -in. poly tubing will be lowered into the rod string to the top of the expandable point, to fill the rods with carbon dioxide gas, plus $100 \%$ excess. A $100-\mathrm{mL}$ syringe will be attached to the poly tubing connected to the expandable point holder, and a volume of gas equal to the volume of the poly tubing will be extracted and discharged to the atmosphere. Then a second sample will be extracted and discharged into a landfill gas analyzer to check for carbon dioxide gas (as a leak detector). If no carbon dioxide gas is detected, the Geoprobe rods will be retracted back to $6 \mathrm{ft}(185 \mathrm{~cm})$ BGL to expose the PRT tip to the soil for vapor collection. A soil gas sample will be then withdrawn through the tubing into a metal, certified-clean, 1-L gas canister. After sampling is complete, the rods will be removed. The borehole remaining in the soil will be plugged with bentonite chips, hydrated with sufficient clean, fresh water to allow the bentonite to expand and form a tight seal, and the hole in the cement floor will be sealed with cement.

All soil gas samples collected in gas canisters will be shipped immediately to TestAmerica Laboratories, Inc., South Burlington, Vermont, for VOCs analysis with EPA Method TO-15.

\subsection{Methods for Deeper Soil Sampling and Analysis}

Deeper soil sampling (Section 3.2.1.3) will be performed by using the Argonne 22-ton, track-mounted CPT crawler, if possible, to achieve the target depth at the top of the saturated sand and gravel unit (100-120 ft BGL). At each investigation location, soil samples will be collected at depth intervals of 4-8 ft from $30 \mathrm{ft}$ BGL to the depth of groundwater in the sand and gravel unit. The CPT sampling method is described in Section 4.1.

If drilling is necessary to reach the saturated sand and gravel unit at 100-120 $\mathrm{ft} \mathrm{BGL,} \mathrm{a}$ sonic drilling rig will be employed. To collect soil samples or soil cores with the sonic rig, an 
inner drill string with core barrel will be advanced $5 \mathrm{ft}$ or $10 \mathrm{ft}$ at a time, followed by advancement of an outer sonic casing. The inner barrel will then be pulled, and the soil core will be extracted for sampling or lithologic evaluation. Samples of deeper soils will be collected every 5-10 ft from the cores recovered with the sonic drilling rig.

The soil samples recovered from the core barrel will be placed immediately in jars, then sealed, preserved on dry ice in the field, and shipped to the AGEM Laboratory for purge-andtrap sample preparation with analysis by GC-MS (EPA Methods 5030B and 8260B). As discussed in Section 4.1, preservation of soil samples with dry ice will improve the recovery of VOCs compared to traditional procedures using sample additives.

At selected locations and depth intervals, soil samples will be also collected from cores for soil property testing (e.g., moisture content, porosity, bulk density), grain size analysis, and other chemical analysis (total organic carbon, etc.).

\subsection{Methods for Deep Boring and Logging}

The deep subsurface borings discussed in Section 3.2.1.3 (Task 1c), Section 3.2.2 (Task 2), and Section 3.2.3 (Task 3) will obtain the key data for characterizing the site-specific geologic and hydrogeologic sequences, as an aid in guiding groundwater sampling and to provide a better understanding of the site-specific conceptual model. The borings will be implemented by using the CPT and/or a sonic drilling rig.

Initially, at each proposed deep soil sampling location to the depth of 100-120 ft BGL (Task 1c), the electronic CPT cone might be used to acquire continuous geomechanical measurements of tip pressure, sleeve friction, conductivity (if possible), and tip-versus-sleeve ratio. The resulting logs will document sensor responses to the vertical sequence of sediments penetrated, for possible correlation with the site-specific lithologies and stratigraphy, as well as the presence of water (if possible). The findings will be verified in corresponding cores recovered later with the CPT through a 4-ft-long soil coring barrel fitted into the push rod.

If the CPT cannot reach the desired depth (100-120 ft BGL) to the top of the saturated sand and gravel unit for the deeper soil sampling points (Figure 3.1), boring will be conducted with a sonic drilling rig. The 4-in.-diameter cores will be recovered by using a 6-in.-diameter 
inner core barrel at depth increments of approximately $10 \mathrm{ft}$. The drilling will take place within an 8-in.-diameter overriding casing, which will be advanced as the coring progresses to prevent potential cross-contamination of the deeper soil intervals by any contamination that might be present at shallow depths.

For the deep boring to a proposed depth of approximately $180 \mathrm{ft}$ BGL near the grain storage structures at the former CCC/USDA facility and the four additional borings to similar depth (180 ft BGL) along the edge of the former CCC/USDA facility and the upgradient location (Figure 3.2), the sonic drilling rig is expected to be required for penetration. Cores will be collected as discussed above.

At each boring location, cores recovered with either the CPT or the sonic drilling rig will be examined to evaluate lithology, characteristics of the aquifer unit, and water content and water recovery conditions. The results of this evaluation will be documented in a boring log for each boring location. Information on the vertical distribution of various properties, as identified by analyzing the continuous cores, will be evaluated to determine the site-specific stratigraphic and hydrogeologic sequences in the context of the local hydrogeologic setting.

\subsection{Methods for Groundwater Sampling and Analysis}

As discussed in Sections 3.2.1.3, 3.2.2, and 3.2.3, groundwater samples will be collected from the bases of the vertical soil profiles (Task 1c) at the deeper soil sampling points (top of the saturated sand and gravel unit), as well as from the permeable intervals in the aquifer at one deep boring near the grain storage structures at the former CCC/USDA facility (Task 2) and the four deep borings along the edge and in the southern part of the former facility (Task 3; Figure 3.2).

\subsubsection{Groundwater Sampling with the Cone Penetrometer}

At each CPT deeper soil sampling point (Section 3.2.1.3), the CPT rods will be used to push a sacrificial tip and 0.5-in.-I.D. polyvinyl chloride (PVC) filter screen and riser to the desired maximum sampling depth. The rods will then be partially withdrawn to the desired upper sampling depth, to expose the screen to the formation waters. Water samples will be collected from the PVC casing by using a bailer, without purging, for preservation and analysis as described in Section 4.5.4. 


\subsubsection{Groundwater Sampling with the Drilling Rig}

At deep borings implemented with the sonic drilling rig (Sections 3.2.2 and 3.2.3), relatively thick permeable units will be the target intervals for groundwater sampling. Once the desired sampling interval is confirmed in the recovered core, as discussed in Section 4.3, groundwater will be collected with a bailer from the portion of the borehole that is exposed to the formation, between the bottom of the overriding (outer) casing and the bottom of the borehole. If necessary, a packer-and-riser technique in which a pair of packers is placed in the borehole on steel piping (a work string) will be employed for discrete groundwater sampling within the aquifer. With this technique, a straddle packer assembly is lowered into the borehole to the desired depth. The pair of packers is then inflated, so that groundwater samples can be collected in the interval between the two packers. Once the groundwater sampling is completed, the packers are deflated and moved to the next zone of interest, then re-inflated for the next sampling.

Water samples will be preserved and analyzed as described in Section 4.5.4.

\subsubsection{Decontamination}

Decontamination of the CPT and drilling rigs, tools, and equipment will be performed as needed, by using a hot-water pressure washer, to ensure the integrity of the media sampled for laboratory analysis at each sampling point.

\subsubsection{Sample Preservation and Analysis}

Groundwater samples collected with the CPT and the drilling rig will be preserved on ice at $4^{\circ} \mathrm{C}$ and shipped overnight to the AGEM Laboratory for rapid-turnaround (24-h) analysis. Water samples will be analyzed by the purge-and-trap method with a GC-MS system (EPA Method 5030B and 8260B). To ensure reproducibility, a minimum of $10 \%$ of the water samples will be selected for verification analysis by a second laboratory (TestAmerica Laboratories, South Burlington, Vermont) with the EPA's Contract Laboratory Program (CLP) methods. An index to the EPA methods is online (http://www.epa.gov/epahome/index/). 
In addition, groundwater samples selected for inorganic geochemical and/or isotope analysis will be preserved on ice at $4^{\circ} \mathrm{C}$ and shipped overnight to TestAmerica Laboratories (South Burlington, Vermont) and the University of Miami (Miami, Florida) for analysis.

\subsection{Methods for Installing Monitoring Wells and Abandoning Boreholes}

Monitoring wells will be installed with a sonic drilling rig. The wells will consist of 2-in. PVC casing installed in 6.25-in.-diameter boreholes. Screens for monitoring wells will be 0.010-in. mill slot PVC, at the appropriate length for the depth. The filter pack will extend from $1 \mathrm{ft}$ below the screen to $2 \mathrm{ft}$ above the screened interval. A 2 - $\mathrm{ft}$ to 5 - $\mathrm{ft}$ bentonite pellet seal will be installed above the filter pack. The remainder of the hole will be sealed with a high-solids bentonite grout slurry by using a tremie pipe, from the top of the bentonite seal to within $3 \mathrm{ft}$ of the ground surface. The surface will be completed with a 12-in. flush-mount well cover, cemented in place. The top of the casing will be fitted with a 2-in. locking J-plug.

All wells will be constructed in accordance with Nebraska guidelines (Title 178 NAC 12). Any variances required will be obtained from the appropriate agency prior to installation. All investigation-derived waste (IDW) will be managed as described in Section 4.7. After installation, each well will be pumped and developed for a minimum of $2 \mathrm{~h}$, or as determined by the attendant drilling engineer to be necessary.

All CPT investigation boreholes and all drilled boreholes that are not selected for completion as monitoring wells will be abandoned according to Nebraska requirements (Title 178 NAC 12).

\subsection{Methods for Water Level Monitoring}

Groundwater levels will be monitored continuously in all monitoring wells or in a subset of selected monitoring wells, as well as in one or both of the public water supply wells (subject to access), by using programmable downhole pressure sensors and data loggers (Instrumentation Northwest PT2 $\mathrm{X}^{\mathrm{TM}}$ devices). The data logger at each location will be programmed initially to record one measurement every $30 \mathrm{~min}$. The data from the loggers will be downloaded after approximately 1 month of operation, and the resulting hydrographs will be examined for possible evidence of pumping effects at the public water supply wells and/or nearby private wells, as well 
as other short-term variations in the local groundwater levels. On the basis of these results, monitoring will either continue at the original measurement frequency, or the loggers will be reprogrammed to a recording interval suitable for extended monitoring. The monitoring period will be extended to 6-12 months to document possible variations in responses to pumping at well PWS 68-1 and the surrounding irrigation wells, as well as short-term, seasonal, or other potential changes in groundwater levels.

Groundwater levels will also be measured manually in all monitoring wells at each data logger downloading event, to confirm that the sensors and loggers are performing appropriately.

\subsection{Methods for Handling and Disposal of Investigation-Derived Waste}

The approach to handling and disposal of soil and water IDW will be as follows:

- Soil cores collected during sampling will be retained in core boxes for lithologic description and research. The cores will be transported to and stored at an Argonne facility for further reference.

- Soil IDW from drilling activities will be stored on-site in 55-gal drums or a roll-off container. A representative sample will be collected and analyzed for VOCs by the AGEM Laboratory and by the toxicity characteristic leaching procedure (TCLP) by TestAmerica Laboratories, Inc., South Burlington, Vermont.

- A Solid Waste Disposal Authorization will be obtained from the NDEQ for disposal of soil on-site or in a permitted landfill. If analytical data indicate that the soils cannot be placed in a permitted landfill, alternative disposal methods will be proposed to the NDEQ for review.

- Water IDW will be stored on-site in 55-gal drums or polyurethane containers. All containers will be covered and stored on the site prior to disposal. The wastewater will be analyzed for VOCs by the AGEM Laboratory. 
- If analytical results for the wastewater indicate concentrations of carbon tetrachloride, chloroform, and methylene chloride below the MCLs, then the water will be discharged on-site, away from known sensitive receptors. If the analytical results indicate concentrations above the MCLs, then the water will be disposed of at a wastewater treatment facility approved by the NDEQ.

\subsection{Quality Assurance/Quality Control for Sampling and Analysis}

Quality in sampling and analysis will be assured through documentation of activities, performance and system audits, and periodic evaluations of QC procedures. The project QA/QC requirements will be satisfied through periodic and final reviews covering all aspects of sampling, field measurements, chemical analyses, data collection, data reporting, instrument calibrations, routine maintenance of analytical equipment, and standardization procedures in analyses. In addition, technical review of the results will ensure that the stated objectives of the project are met.

Conditions significantly adverse to quality, their causes, and corrective actions taken will be documented and reported to the technical project manager, the QA/QC coordinator, and the AGEM program manager. Examples of such conditions are deficiencies in the use of procedures or instructions, failure to implement corrective actions in response to nonconformances with quality standards, and unexpected loss of or damage to documentation. Corrective action will be implemented in a timely manner, and the field team will be informed of the issue. Actions taken to correct problems or deficiencies during sampling in the field or during laboratory analyses will be documented and described in the QA portion of the sampling and analysis report.

\subsubsection{Field Quality Assurance/Quality Control for Sampling and Analysis}

\subsubsection{Sample Collection}

The following two major criteria must be met in sampling:

1. The samples must be a genuine representation of the conditions prevalent at the site. 
2. Adequate numbers of samples must be available for meaningful characterization or monitoring of the site, in the judgment of the technical project manager and the AGEM program manager and with the concurrence of the sponsoring and regulatory agencies.

In some cases, it might not be possible to collect samples from an intended location because of access constraints. In such cases, alternate or additional samples will be collected, as appropriate, from accessible areas, if this can be accomplished without compromising the original objectives of the work.

All samples will be recorded in a field document dedicated to the specific site under investigation. Records will be as complete as possible, with the goal of supporting resolution of any issues that might arise in the future.

\subsubsection{Calibration Procedures for Field Analytical Instruments}

The technical project manager, in conjunction with team members, will ensure that instruments used for field measurements are properly calibrated, reliable, and in good working order. Standards will be protected from extreme weather conditions and discarded on the expiration date, so that outdated standards cannot be used inadvertently.

The typical field measurements derived from water samples are temperature, $\mathrm{pH}$, and electrical conductivity. Calibration information will be documented in a dedicated record for each instrument. The record will include the instrument's name and model or serial number, the date of calibration and calibration method, and the signature of the person performing the calibration. The record will also contain dated, signed entries for all actual field measurements.

\subsubsection{Field Blanks, Field Rinsates, Field Replicates, and Trip Blanks}

The QC samples collected as part of the field sampling activity will include field blanks, field rinsates, field replicates, and trip blanks. Field blanks and field rinsates are samples of waters used for and after decontamination of field equipment, respectively. Field replicates provide a measure of consistency in both sampling and analytical methodologies. Trip blanks will be included in shipments of samples for VOCs analyses to demonstrate that cross- 
contamination of samples has not occurred during shipment. The nature and frequency of these types of samples will be as follows:

- Field Blanks

A field blank is a sample of the water used in the field for decontamination. This water is obtained from an uncontaminated source in the field or is transported to the field expressly for decontamination and other sampling activities. Blanks of other materials that might affect sample integrity will also be collected as necessary. Analysis of field blanks for VOCs will verify that contamination has not been introduced into the samples from outside sources. One field blank will be prepared during each sampling event when water is used.

\section{- Rinsates}

Some equipment (e.g., sampling bailers) is used repeatedly in sampling activities. This equipment must be decontaminated after each use to avoid cross-contamination of samples. A rinsate sample consists of water rinsed over a piece of sampling equipment after it has been cleaned and decontaminated. Rinsate samples will be collected with a frequency of 1 sample per 20 pieces of equipment cleaned, with a minimum of 1 sample per cleaning session. All rinsate samples will be analyzed for VOCs.

\section{- $\quad$ Trip Blanks}

Trip blanks (soil or water) may be prepared at the AGEM Laboratory or in another suitable uncontaminated area and transported to the field site. Trip blanks may also be prepared with appropriate care at the field site. A blank sample will be shipped to the laboratory in each container of field samples for VOCs analyses. Trip blanks will be analyzed only for VOCs. Any indication of contamination will be reported to the field team immediately, so that action can be taken to identify the source of contamination and rectify the problem.

\section{- Field Replicates/Split Samples}

Field replicates of soil, water, and vegetation samples are used to verify consistency in the sampling methodology and the reproducibility of the analytical results. The required frequency is 1 replicate for every 10 samples 
collected, but replicates will be collected more frequently if the particular situation warrants. All field replicates collected will be analyzed.

\subsubsection{Laboratory Quality Assurance/Quality Control for Sampling and Analysis}

\subsubsection{Laboratory Duplicates}

In addition to sample replicates prepared in the field, the analytical laboratory will select some samples at random for duplicate analyses. This procedure will allow for quantitation of the precision of the laboratory analysis.

\subsubsection{Volatile Organic Analysis}

Samples collected for VOCs analyses will be shipped to the AGEM Laboratory or to an EPA-certified CLP laboratory for immediate analysis. Analysis of the samples will be prioritized in consultation with the technical project manager, so that the results can be used to optimize decision making in the field. Water samples will be analyzed by using modifications of EPA Methods 5030B and 8260B (purge-and-trap method on a GC-MS system) or a modification of EPA Method 524.2 (for drinking water). Soil samples will be analyzed by using a modification of EPA Methods 5030B and 8260B (Level V). The shallow subsurface soil samples will be analyzed with a modification of EPA Method 5021 (headspace analysis on a GC with electron capture detection). Soil gas samples will be analyzed by an EPA-certified CLP laboratory using EPA Method TO-15.

In reviewing the analytical results, $\mathrm{QA} / \mathrm{QC}$ procedures will be verified in the following laboratory-related areas:

- Chain-of-custody records for samples

- Storage of samples and sample extracts

- Holding times before analyses 
- Calibration and maintenance of analytical instruments

- Performance standards for instruments (reproducibility, internal and external standards, spike recoveries, etc.)

- Field records

The verification will involve thorough evaluation of laboratory practices and procedures, audits of field records, and review of data packages (both original and reduced forms of data) by the project QA/QC coordinator. The results of this evaluation, in keeping with EPA guidelines (EPA 2008), will be presented in the QA/QC portion of the sampling and analysis report.

At least $10 \%$ of all water and soil samples collected in a given sampling event (or a minimum of 1 sample if fewer than 10 are collected) will be shipped to an EPA-certified CLP laboratory for a second analysis to verify the results obtained by the AGEM Laboratory. Samples may be sent directly to the CLP laboratory from the field, or they may be selected for verification analysis on the basis of the AGEM Laboratory's results. When possible, the samples selected in the AGEM Laboratory will have a wide range of carbon tetrachloride values (from below the detection limit to high concentrations) to allow comparison of the analytical methods over the range of concentrations found. Water samples will be analyzed by the reference laboratory according to the CLP procedure SOW SOM01.2-trace (EPA 2014b), with a quantitation limit of $5 \mu \mathrm{g} / \mathrm{L}$. Soil samples will be analyzed by EPA Method 8260B, as referenced in the EPA's SW-846 (EPA 1998), with a quantitation limit of $10 \mu \mathrm{g} / \mathrm{kg}$. Each sample subjected to verification analysis by the reference laboratory will be accompanied by complete CLP documentation.

\subsubsection{Other Analyses}

Selected samples may be subjected to other analyses (unrelated to site contamination) to aid in development of the site hydrogeologic model. Groundwater samples may be selected for inorganic or tritium analysis to aid in characterization of groundwater geochemistry. Soil samples may be selected for analysis of physical parameters such as particle size, bulk density, or percent moisture. These analyses will be conducted by certified laboratories with accepted procedures. The analytical methodologies used and results of a review of QC procedures for these analyses will be presented in the sampling and analysis report as appropriate or requested. 


\subsubsection{Quality Assurance Records}

Records that document quality will be assembled and maintained. Records will be legible, identifiable, and retrievable and will be protected against damage, deterioration, or loss. Such QA records pertain to all activities related to sampling and analysis. The QA records include soil boring logs, well completion logs, other field records, sample labels, and chain-ofcustody records. These records will be retained for a minimum of $10 \mathrm{yr}$ after the program ends.

\subsubsection{Field Notes Related to Sample Collection}

All field notes relating to the collection of samples will be placed in the permanent project records. Notes will provide information on the sampling conditions and sample handling and collection methods. The sample identification number, the date and time of sampling, the place of collection (with a simple hand-drawn location map), the weather conditions at the time of sampling, and any measurements made by field monitoring equipment will be the minimal data recorded. Each entry will be signed by the sampler.

\subsubsection{Sample Labels}

A uniquely numbered sample label will be affixed to each sample container to identify the sample; the date, time, and location of sampling; and the analysis to be performed.

\subsubsection{Chain-of-Custody Records for Samples}

A uniquely numbered chain-of-custody record will be maintained to track the possession of each sample throughout its history, from the time of collection to the time of delivery to the analytical laboratory. The chain-of-custody record is discussed in Master Work Plan (Argonne 2002). One copy of a chain-of-custody record will accompany each sample container. The second copy will be retained by the technical project manager until completion of the investigation, when it will be placed in the permanent project record. 


\subsubsection{Analytical Data Reduction, Validation, and Reporting}

\subsubsection{Analytical Data Reduction}

All sampling logbooks and related records (for both sample collection and sample analysis) completed during individual tasks will be submitted to the QA/QC coordinator for storage with the project files. The analytical results, with all pertinent information about sample locations and sampling conditions, will be entered into a computer file for integration with results from other activities and for presentation in the final report.

\subsubsection{Analytical Data Validation}

If minimal QC requirements are not met by the analytical laboratory, all data from the associated batch of samples will be thoroughly scrutinized. If no analytical problems are found, the data and out-of-control parameter(s) will be discussed in the QA/QC section of the sitespecific report. If problems with the analytical data are found, the samples associated with the batch will be reanalyzed, and the data from the reanalysis will be reported. If holding times defined in the procedure for the reanalysis are exceeded, both sets of data will be reported.

In the final report, all sample data will be presented, along with detection limits and concentrations found.

\subsubsection{Analytical Data Reporting}

For all analyses, the laboratory report will show, at a minimum, traceability to the sample analyzed. The report will contain the following information:

- Project identification

- Field sample number

- Laboratory sample number 
- Sample matrix description

- Date of sample collection

- Date of sample receipt at the laboratory

- Analytical method description

- Individual parameter results

- Date of analysis (extraction, first runs, and subsequent runs)

- Quantitation limits achieved

- Dilution of concentration factors

- Corresponding QC report (to include method blanks, blanks/spikes, and continuing calibrations)

- Raw chromatogram data

- Chain-of-custody forms

- $\quad$ Case narrative (where appropriate)

\subsection{Field Investigation Schedule}

The proposed Phase I investigation will be conducted in one or more field sessions, as required to accomplish the program objectives. The proposed activities are summarized in Table 3.1.

The first field session will include the following tasks with a CPT unit and a small Geoprobe: (1) initial sampling of shallow soils at 10 locations (Task 1a; Section 3.2.1.1); (2) soil 
gas sampling beneath two Quonsets (Task 1b; Section 3.2.1.2); and (3) deeper soil sampling at selected locations (up to 3 locations) to the depth of the top of saturated sand and gravel unit, as well as groundwater sampling from the saturated unit $(<120 \mathrm{ft})$, if the CPT can reach the desired depth (Task 1c; Section 3.2.1.3) (Figure 3.1). The results of the first field session will be analyzed to identify the target deep boring location for characterizing the site-specific geology and aquifer system and confirming the four additional groundwater sampling locations (Figure 3.2) that will be implemented in the subsequent field session(s).

The second and third (if necessary) sessions will consist of the following tasks with a sonic drilling rig:

- Coring and groundwater sampling at one deep boring in the northern part of the former CCC/USDA facility (selected on the basis of results obtained in the deeper soil sampling (Task 2; Section 3.2.2).

- Coring and groundwater sampling at four additional deep borings along the edge and in the southern part of the former CCC/USDA facility (Task 3; Section 3.2.3; Figures 3.2).

- Installation of monitoring wells at five deep boring locations, with appropriate depths and screen intervals (Task 4; Section 3.2.4).

Field work will be conducted in cycles of approximately 10 days on and 4 days off, subject to the specific requirements of the activities being performed and the approval of the CCC/USDA and NDEQ project managers for subsequent sessions. 


\section{Community Relations Plan}

This community relations plan identifies issues of community concern regarding the proposed field investigation and outlines community relations activities to be conducted during the Phase I investigation at Bladen.

Community concern is likely to increase when the field work begins and Argonne's presence becomes apparent. Effective community relations will require close contact with residents, both within and outside the village limits. Information will be made available, as appropriate, in the local area to ensure that interested residents are adequately informed.

Argonne will develop a fact sheet that describes the investigation and will provide copies to the village office and to interested residents at and near the investigation area. The fact sheet will provide the names and contact information for the NDEQ and CCC/USDA officials and Argonne staff members involved in the investigation.

This community relations plan is divided into sections including site description, community background, community relations objectives, timing of community relations activities, and contact list of key officials.

\subsection{Site Description}

Section 2 of this report contains a complete description of the site and its history.

\subsection{Community Background}

The incorporated village of Bladen is governed by a village board chairman and a village board. In addition to public works and other village responsibilities, the chairman and board have authority to provide and maintain the municipal water supply system. The board employs a fulltime village maintenance superintendent who is charged with maintaining the water system. The village operates an office that is staffed by the village clerk.

Residents within the limits of the village of Bladen receive their drinking water from the village public water supply system, which is currently supported by two wells, PWS 68-1 (35\%) 
and PWS 2006-1 (65\%). The village recently received a grant and loan from the USDA's Rural Development Program for upgrades to Bladen's public water supply infrastructure. Upgrades will include new water mains, complete renovation of the existing water tower, installation of meters, and mechanical improvements to the two existing public wells.

\subsubsection{History of Community Involvement Associated with Well Contamination}

Well PWS 68-1 is tested annually, with the last sampling event on July 22, 2013. Carbon tetrachloride was detected in 6 of the 10 sampling events at low concentrations $(0.47-3.83 \mu \mathrm{g} / \mathrm{L})$. Slightly elevated nitrate concentrations of $8-10 \mathrm{mg} / \mathrm{L}$ have also been found in groundwater from PWS 68-1 in every sampling event during July-August of the last 3 yr. Well PWS 68-1 provides an average $35 \%$ of the water for the village public water supply system. No carbon tetrachloride or elevated nitrate has been found in well PWS 2006-1. However, the lifting pressure from well PWS 2006-1 is limited, and a large amount of power is required to lift water into the water tower near well PWS 68-1.

\subsubsection{Key Community Concerns}

Once the proposed Phase I investigation begins and the presence of Argonne staff and contractors becomes apparent, nearby residents are likely to become curious. This community relations plan is being developed in anticipation of the potential for greater community interest. Community concerns will be gauged during and after the site investigation and addressed appropriately, as needed.

\subsection{Community Relations Objectives}

The Bladen community relations plan has the following major objectives:

1. Explain the CCC/USDA's investigation plans and provide general information about the hazardous waste program.

2. Present the proposed Phase I investigation plan and activities to village officials and the current property owner and local manager of the CHS facility 
(the former CCC/USDA facility) and request permission to conduct the proposed activities. Anticipated activities include direct-push boring with the CPT and some drilling.

3. Inform village officials, the current property owner of the former CCC/USDA facility, and other interested residents of the investigation's findings and developments.

4. Respond to residents' inquiries about site activities and the presence of health and environmental hazards.

5. Ensure that the public has appropriate access to technical information and contact individuals for involvement in site-related decisions.

6. Provide appropriate documentation and contact information to enable interested residents to learn about the site.

\subsection{Timing of Community Relations Activities}

This section describes the activities needed to meet the community relations objectives identified in Section 5.3. Many of these activities need to take place before the field work begins. Listed below are milestones and planned activities.

\subsubsection{Activities before Field Work Begins}

The CCC/USDA and Argonne will conduct the following community relations activities, to the extent practicable, before field work begins:

1. A point of contact will be designated for Argonne. The individual will be Argonne's liaison with village officials, the property owner and local manager of the former CCC/USDA facility (currently the CHS facility), and interested residents. 
2. Prior to the Phase I investigation, Argonne will assist the CCC/USDA in obtaining an access agreement with CHS, Inc., for the proposed investigation activities.

3. Upon obtaining approval from the CCC/USDA, Argonne will make further contact with the local CHS manager and village officials to explain the proposed activities and schedules.

4. Argonne will make arrangements to present and discuss the Phase I investigation plan to the village board and will request the board's approval for drilling and associated activities in support of the site investigation within $1,000 \mathrm{ft}$ of the well PWS 68-1.

5. Argonne will arrange for discussions (by telephone and in person) with interested residents and any other affected parties, as appropriate, to address their concerns and information needs.

6. Upon completion and approval of this site-specific Work Plan, Argonne will provide a copy of the document to the village for public viewing by interested parties.

\subsubsection{Activities during Field Work}

The CCC/USDA and Argonne will provide for the conduct of the following community relations activities, to the extent practicable, during field work:

1. Meetings with interested residents and other parties when needed.

2. Preparation and distribution of fact sheets or letters to inform the community of the investigation's progress, significant milestones, or changes in plans.

3. Continued telephone contact with interested residents and with state and local officials. 
4. Arrangements for site visits by interested parties, within allowable safety limitations.

\subsubsection{Activities upon Completion of Field Work Activities}

The CCC/USDA and Argonne will conduct the following community relations activities, to the extent practicable, upon completion of the field work:

1. If requested, arrange for a meeting with village officials and interested residents, as appropriate, to present and discuss the investigation's findings, results, and recommendations, as well as any future activities at the site.

2. Prepare and distribute printed information outlining the investigation's results and any future activities at the site, as appropriate.

3. Provide a copy of the final report that documents results of the investigation to the village for public viewing by interested parties.

\subsection{Contact List of Key Officials}

The contact list for use during Phase I work is below. The list includes key federal, state, local officials, and Argonne contacts.

\section{Local Officials}

Village of Bladen Office

211 North Main Street

Bladen, NE 68928

bladenclerk@gtmc.net

Village Clerk/Treasurer: Debbie Thayer

402-756-1369 (office)

402-469-9083 (cell)
Bladen Village Board

Roger Fassler, Chairman

Meleah Armes, Member

Mike Kile, Member

Arlo Thayer, Member

Tara Vance, Member
Village Maintenance

Superintendent

Keith Pavalkan

402-469-5782 (cell) 


\section{CHS Agri Service Center Contacts}

Bladen Service Center Manager

Andy Klein

206 South Main Street

Bladen, NE 68928

402-765-1331

Andrew.klein@chsinc.com
Lincoln Area Safety Director

Allen Mintzmyer

310 Logan Street

Holdrege, NE 68949

308-998-8626

Allen.mintzmyer@chsinc.com

\section{Federal Agency Officials}

Steve Gilmore

Conservation and Environmental Protection Division

Farm Service Agency

Commodity Credit Corporation

U.S. Department of Agriculture

Room 4725, Stop 0513, South Agriculture Building

1400 Independence Avenue, SW

Washington, DC 20250-0513

202-720-5104

Steve.Gilmore@usda.gov

\section{State Agency Officials}

Mike Felix

Supervisor of Remediation Section

Waste Management Division

Nebraska Department of Environmental Quality

Suite 400, The Atrium, 1200 N Street

P.O. Box 98922

Lincoln, NE 68509-8922

402-471-2938

402-471-2909 (fax)

mike.felix@nebraska.gov

\section{Ben Kittrell}

Groundwater Geologist

Remediation Section

Waste Management Division,

Nebraska Department of Environmental Quality

Suite 400, The Atrium, 1200 N Street

P.O. Box 98922

Lincoln, NE 68509-8922

402-471-3377

402-471-2909 (fax)

wade.gregson@nebraska.gov
Ed Southwick

Supervisor, RCRA/Federal Facilities Unit

Remediation Section

Waste Management Division

Nebraska Department of Environmental Quality

Suite 400, The Atrium, 1200 N Street

P.O. Box 98922

Lincoln, NE 68509-8922

402-471-2181

402-471-2909 (fax)

ed.southwick@nebraska.gov 


\section{Argonne Contacts}

Lorraine M. LaFreniere, Ph.D.

Manager, Applied Geosciences and Environmental Management Section

Environmental Science Division

9700 South Cass Avenue

Argonne, IL 60439-4843

630-252-7969

lafreniere@anl.gov

Eugene Yan, Ph.D.

Bladen Project Manager

Environmental Science Division

9700 South Cass Avenue

Argonne, IL 60439-4843

630-252-6322

eyan@anl.gov
James Hansen

Community Relations Representative Environmental Science Division

Argonne National Laboratory

955 L'Enfant Plaza SW, Suite 6000

Washington, DC 20024

202-488-2453

hansenj@anl.gov 


\section{Health and Safety}

The general health and safety plan for use during the work at Bladen is in Section 3 of the Master Work Plan (Argonne 2002). That document addresses all anticipated safety issues for the activities at the Bladen site. Specific emergency information for use at the site is in Table 6.1.

The village of Bladen has emergency 911 service. All emergency calls, including police, fire, and ambulance calls, will be directed for an appropriate response from this number. The local major medical services are provided by Mary Lanning Healthcare in Hastings, Nebraska, approximately $33 \mathrm{mi}$ north of Bladen. The travel time for driving is about 40 minutes. Driving directions to the hospital and a map showing the route are in Figure 6.1. Additional emergency information is in Table 6.1. 
TABLE 6.1 Emergency information for the investigation at Bladen, Nebraska. ${ }^{a}$

\begin{tabular}{|c|c|c|}
\hline Resource & Telephone Number & Name \\
\hline All Emergencies & 911 & $\begin{array}{l}\text { Ambulance, fire, police } \\
\text { (Be prepared to give your location.) }\end{array}$ \\
\hline Hospital & $402-463-4521$ & $\begin{array}{l}\text { Mary Lanning Healthcareb } \\
715 \text { North Street, Hasting, NE } 68901\end{array}$ \\
\hline $\begin{array}{l}\text { Fire Protection } \\
\text { (nonemergency) }\end{array}$ & $402-756-1420$ & $\begin{array}{l}\text { Bladen Volunteer Fire Department } \\
221 \text { Thorne Street, Bladen, NE } 68928\end{array}$ \\
\hline Sheriff (nonemergency) & $402-746-2722$ & $\begin{array}{l}\text { Webster County Sheriff } \\
641 \text { North Cedar Street, Red Cloud, NE } 68970\end{array}$ \\
\hline Industrial Hygiene & $630-252-3310$ & Argonne-Industrial Hygiene \\
\hline Safety & $630-988-9706$ & $\begin{array}{l}\text { EVS Divisionc Field Safety Coordinator } \\
\text { (Monte Brandner) }\end{array}$ \\
\hline \multirow[t]{4}{*}{ Management } & $630-252-4878$ & $\begin{array}{l}\text { EVS Divisionc Environmental, Safety, and } \\
\text { Health Coordinator (Bill Gasper) }\end{array}$ \\
\hline & $630-252-7969$ & $\begin{array}{l}\text { AGEM Program Manager } \\
\text { (Lorraine LaFreniere) }\end{array}$ \\
\hline & $\begin{array}{l}630-252-1275 \\
630-408-7114\end{array}$ & AGEM Field Project Manager (David Surgnier) \\
\hline & $630-252-6322$ & $\begin{array}{l}\text { AGEM Technical Project Manager } \\
\text { (Eugene Yan) }\end{array}$ \\
\hline Security & $\begin{array}{l}630-252-5737 \\
630-252-5731\end{array}$ & $\begin{array}{l}\text { Argonne-Operations Security (workdays) } \\
\text { (after hours and weekends) }\end{array}$ \\
\hline Poison Control & $800-222-1222$ & Nebraska Regional Poison Center \\
\hline Utilities Survey & $800-331-5666$ & $\begin{array}{l}\text { Diggers Hotline of Nebraska, Omaha, NE } \\
\text { http://www.ne1call.com/ }\end{array}$ \\
\hline
\end{tabular}

a Post this table in the field operations base.

b The route from Bladen to the Mary Lanning Healthcare is shown in Figure 6.1.

c Environmental Science Division at Argonne. 


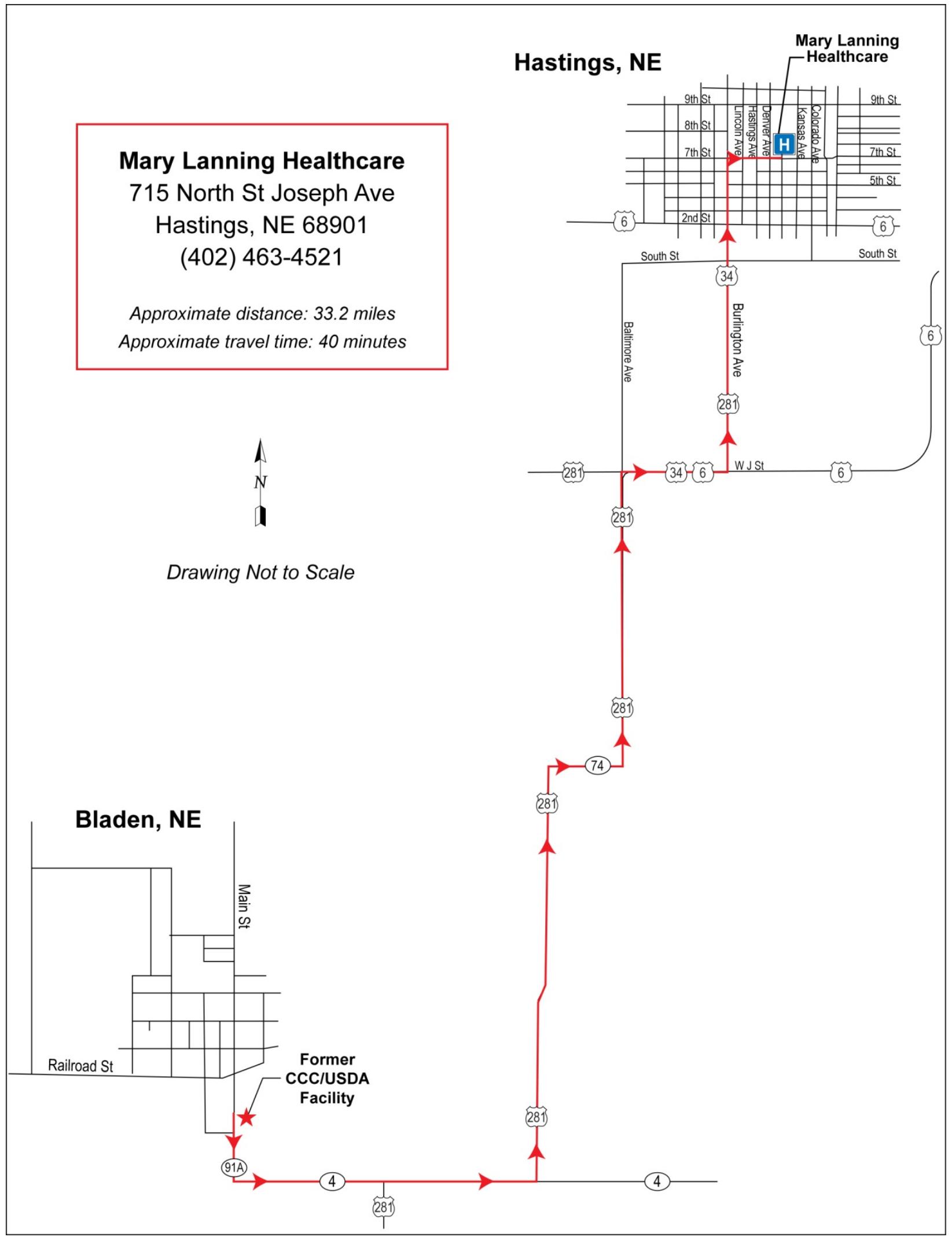

FIGURE 6.1 Emergency route from the Bladen site to the Hastings Hospital (Mary Lanning Healthcare). 


\section{References}

Alvarado, J.S., and C. Rose, 2004, "Static Headspace Analysis of Volatile Organic Compounds in Soil and Vegetation Samples for Site Characterization," Talanta 62:17-23.

Argonne, 2002, Final Master Work Plan: Environmental Investigations at Former CCC/USDA Facilities in Nebraska, 2002 Revision, ANL/ER/TR-02/003, prepared for the Commodity Credit Corporation, U.S. Department of Agriculture, Washington, D.C., by Argonne National Laboratory, Argonne, Illinois, December.

Bladen Opera House Centennial Book Committee, 1986, Bladen, The First 100 Years (1886-1986), Walsworth Publishing Company, Marceline, Missouri.

CRC, 1999-2000, CRC-Handbook of Chemistry and Physics, 80th edition, edited by David R. Lide, CRC Press, Boca Raton, Florida.

DNR, 1993, Nebraska Digital Orthophoto Quadrangles, Nebraska Department of Natural Resources, Lincoln, Nebraska, July-August, http://www.dnr.ne.gov/digital-imagery-1993through-2012-1-2-meter.

DNR, 1999, Nebraska Digital Orthophoto Quadrangles, Nebraska Department of Natural Resources, Lincoln, Nebraska, July-August, http://www.dnr.ne.gov/digital-imagery-1993through-2012-1-2-meter.

EPA, 1998, Test Methods for Evaluating Solid Waste: Physical/Chemical Methods, EPA SW-846, 3rd edition, Draft Update IVA, U.S. Environmental Protection Agency, Washington, D.C., January.

EPA, 2008, National Functional Guidelines for Superfund Organic Methods Data Review, OSWER 9240.1-48, USEPA-540-R-08-01, Contract Laboratory Program, Office of Superfund Remediation and Technology Innovation, U.S. Environmental Protection Agency, Washington, D.C., June (http://www.epa.gov/superfund/programs/clp/download/somnfg.pdf). 
EPA, 2014a, Exposure Assessment Models: WhAEM2000, U.S. Environmental Protection Agency, Washington, D.C., http:/www.epa.gov/Athens/software/whaem/index.html, accessed May 9.

EPA, 2014b, CLP Statement of Work (SOW) for Multi-Media, Multi-Concentration Organics Analysis (SOM01.2), Contract Laboratory Program, U.S. Environmental Protection Agency, Washington, D.C., http://www.epa.gov/superfund/programs/clp/som1.htm, accessed May 13.

GSI, 1993, Step 6 Initial Site Assessment, Bladen Sand and Gravel, Bladen, Nebraska, prepared for Bladen Sand and Gravel, Bladen, Nebraska, by Geotechnical Services, Inc., Grand Island, Nebraska, July 6.

GSI, 2004a, RCBA Tier I Report at Petroleum Release Site, Webster County Roads Maintenance Shop, Bladen, Nebraska, prepared for Webster County Roads Department, Red Cloud, Nebraska, by Geotechnical Services, Inc., Grand Island, Nebraska, August 20.

GSI, 2004b, RCBA Tier I Site Investigation, Timm's Service, Bladen, Nebraska, prepared tor Timm's Service, Bladen, Nebraska, by Geotechnical Services, Inc., Grand Island, Nebraska, December 29.

Johnson, C.R., 1960, Geology and Ground Water in the Platte-Republican Rivers Watershed and the Little Blue River Basin above Angus, Nebraska, with Section on Chemical Quality of the Ground Water, Geological Survey Water-Supply Paper 1489, U.S. Geological Survey, U.S. Department of the Interior, Washington, D.C.

Little Blue NRD, 2011, Geologic and Hydro-Geologic Information, Little Blue Natural Resources District, Davenport, Nebraska, http://www.littlebluenrd.org/hydrogeologic study.html, accessed May 14, 2014.

Miller, R.D., R. Van Horn, E. Dobrovolny, and L.P. Buck, 1964, Geology of Franklin, Webster, and Nuckolis Counties, Nebraska, Geologic Survey Bulletin 1165, U.S. Geologic Survey, U.S. Department of the Interior, Washington, D.C., http://pubs.er.usgs.gov/publication/b1165. 
NAIP, 2012, Nebraska Farm Service Agency 2012 Imagery, National Agriculture Imagery Program, Aerial Photography Field Office, U.S. Department of Agriculture, Salt Lake City, Utah, July 31, http://www.dnr.ne.gov/digital-imagery-1993-through-2012-1-2-meter.

NDEQ, 1998, certified letter from G. Wiggins (LUST/ER Section, Water Quality Division, Nebraska Department of Environmental Quality, Lincoln, Nebraska) to D. Timm (Timm's Service, Bladen, Nebraska), regarding petroleum release at Timm's Service, September 22.

NDHHS, 2014, Drinking Water Watch: Safe Drinking Water Information System, Water System No. NE3118303, Nebraska Department of Health and Human Services, Lincoln, Nebraska, http://dhhs.ne.gov/publichealth/Pages/enh_pwsindex.aspx, accessed May 13.

Pavalkan, K., 2014, interview of Pavalkan (Maintenance Superintendent, Village of Bladen, Nebraska) by E. Yan and J. Hansen (Environmental Science Division, Argonne National Laboratory, Argonne, Illinois), January 29.

Schultz, C.B., E.C. Reed, A.L. Lugn, 1951, “The Red Cloud Sand and Gravel, a New Pleistocene Formation in Nebraska," Science 114(2969):547-549.

USDA, 1956, aerial photograph of Bladen, Nebraska, BNR-2R-118, U.S. Department of Agriculture, Washington, D.C., July 25.

USDA, 1963, aerial photograph of Bladen, Nebraska, BNR-3DD-278, U.S. Department of Agriculture, Washington, D.C., September 29.

USDA, 1969, aerial photograph of Bladen, Nebraska, BNR-1KK-78, U.S. Department of Agriculture, Washington, D.C., August 4.

USGS, 1997, Digital Raster Graphics (DRG) 1:24000 Quads of Bladen, Nebraska, Projection: UTM Zone 14 NAD27 (created from USGS 1981 7.5-minute topography maps), U.S. Geological Survey, Reston, Virginia.

Woodward Clyde, 1997, private well sampling records, documented for the Commodity Credit Corporation, U.S. Department of Agriculture, Washington, D.C., by Woodward Clyde, Omaha, Nebraska, November. 


\section{Appendix A:}

Information on Public Water Supply Wells 
Anladen, 19 sic $689+8$

Departncent of H atter Geanurce.

$7700.12,1968$

P. D. Rox $9460^{(1)}$

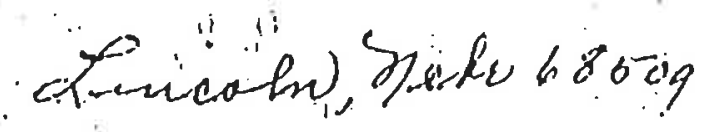

Seav siro:

tim regand to the ariginel thell th $b-28430$.

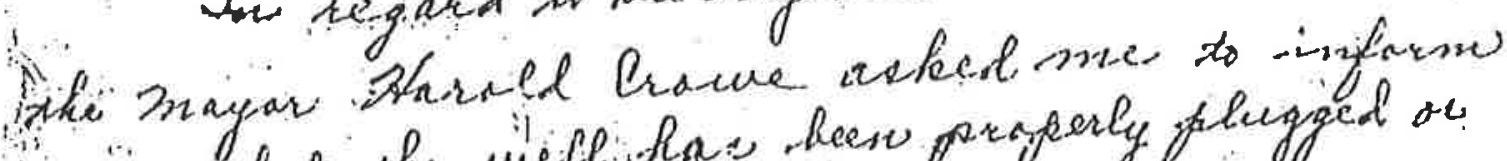
you that the will has hees properly phenged or cappels as provided in Section 46-60:2

zpow reypicifelly

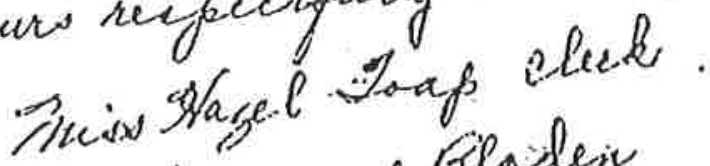

Vitilige of Glader

Bladen, Yets 659.28

$6-28430$

Appendix A, page 2 of 17 


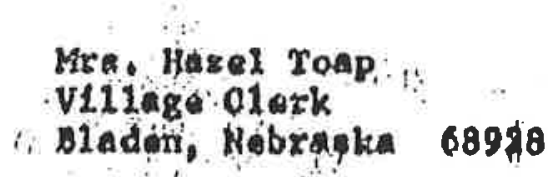

Under the provlstons of seation 46-602 all absindoned wall. hocild ba proporly plugged or cappad. You ohculd, if you hive not alresdy don so, properiy plug or ap tise abandoned

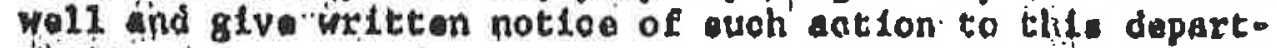
mente :

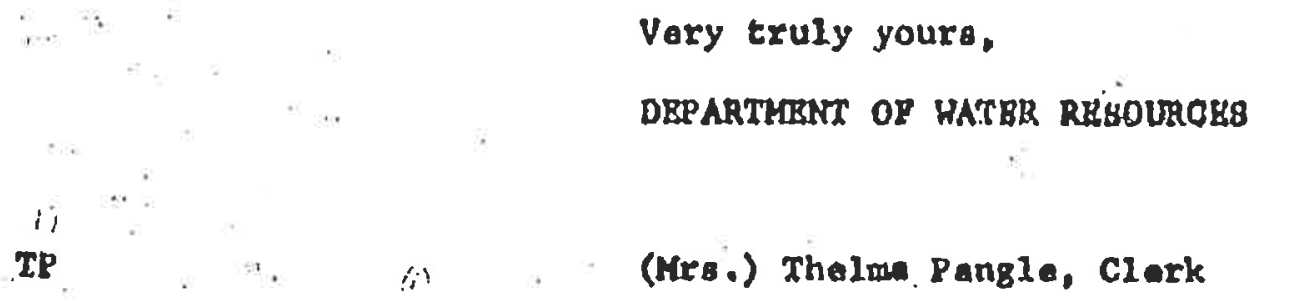




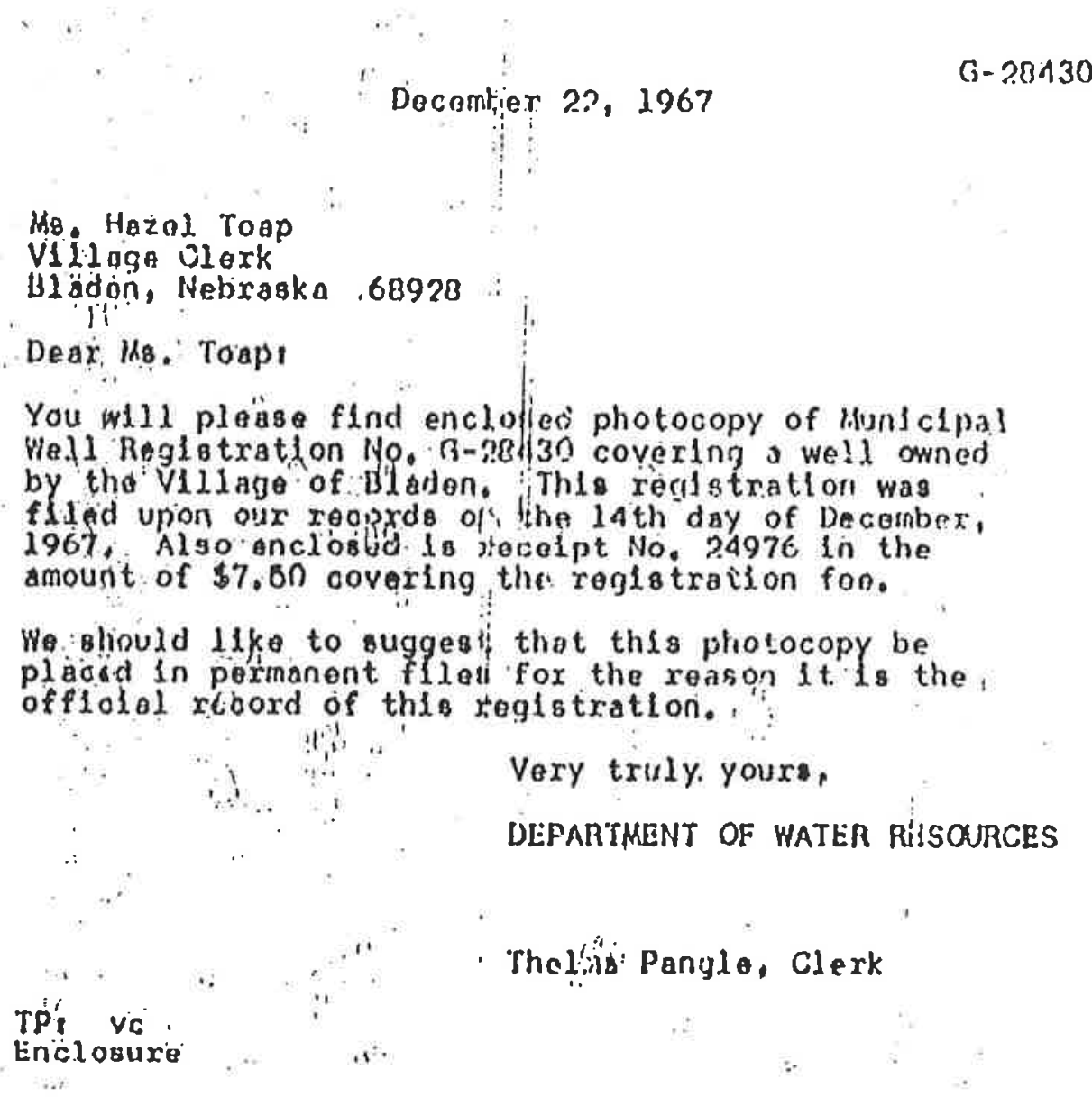


YLIzage 0lork

Hitadon, Kabisaoki

Daar 81xi

Ha wibl to acknowladgo your munleipal wall registration paper covarting une vell owned by, tho villaga of Bladen and located in Section 8 , Township 4 Worth, Range 11 West al the 6th P.M., Wabater County, Nebraska.

You enolused one page and stated on onme that the vizinge of Bladen his tro wello and lncluded plat whositis the locat'in of th1s woll as wall as what Intoxtration was aviliable covering tha woll.

If thax are two walls in Blidem ft. w111 bo necosgary that you cooplate the enclosed forms and return then to this office, togethar with foe of 87.50 to cover the second well. The forras should be ocapleted ao cocisacely posible giving what information you. hivio on thlo woll. It 18 also noted that you did not includo drilier's cartifloate with the reglatration covialag the No. \& woll. If the dxlllex 1o avallable He hould conplate the drilloz's certiflcate fors and werid $i t$ to this oftice soon as possible.

Very truly youra,

DEPARTMBNT OF HATBR RBQPCIRCES

ip:

(Mra.) Theim Patgle, clexk 


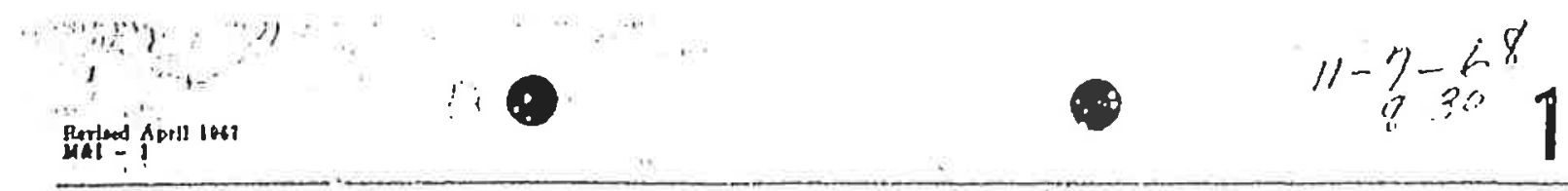

$\frac{\text { Rogistrallon No.... }-28430}{\text { REPLACEMENI WELL }}$

STATE OF NE]SRASKA

AIUNICIPAL OR INDISTRIAI, WELA, REGISTRATION

4

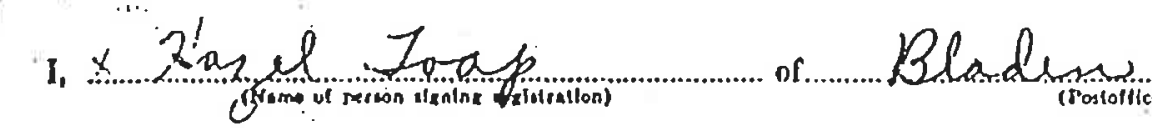

county of...... H.

1st. That the name of the owner of t.jo municjpnl (or) Industrial well registered herein is...

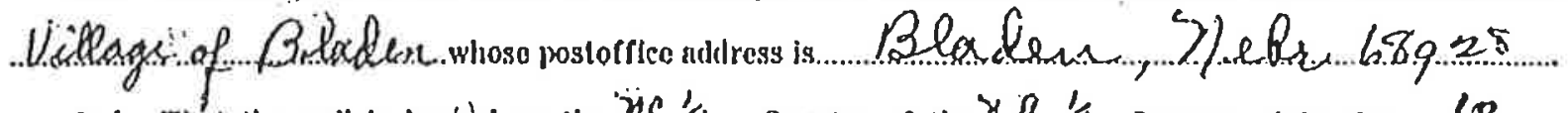

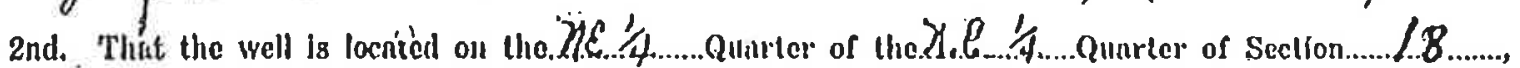

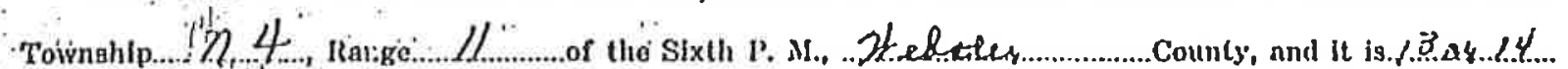
feot from tho

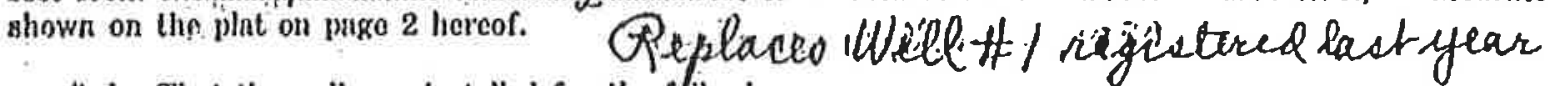

8rd. That the well was installed for the following purnkse or jurproses:.

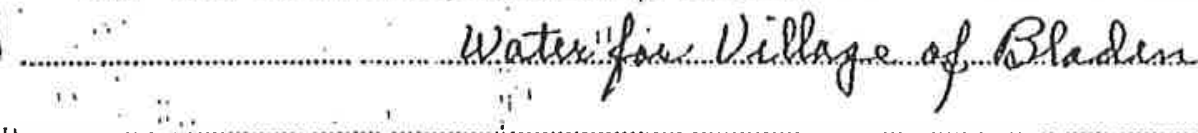

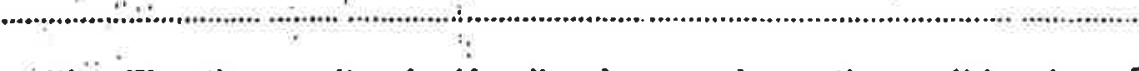

4th. That tho capneity of snl.j well under stormal operating conditions is.......500...........gallons per minute.

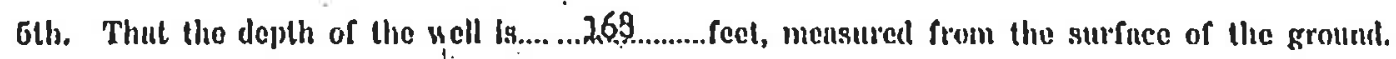

6t!. That the fnside dinneter of the casing is...........18........inches.

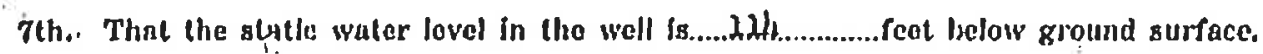

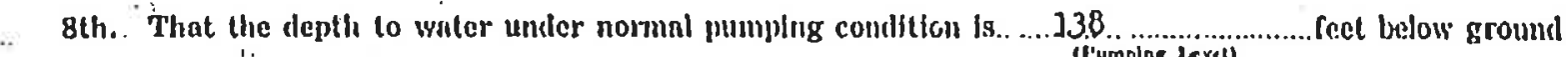
surfince.

(Fumpine devel)

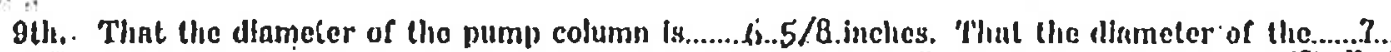
bovl or: Lowls is........10...........inches.

10th. That the type and size of impeller is sts follows:

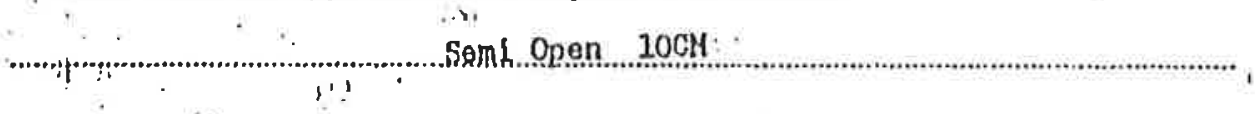

11th: That the , folf was compluted on or alsout tho. . 8.

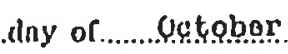
10.68 


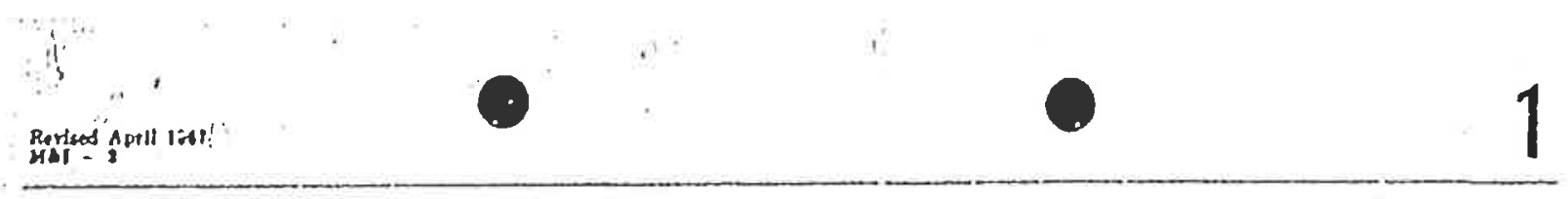

12th. That ntlacined hereto aro three coples of the $\log$ of the well certified to by the driller of the well.

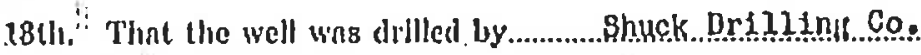
whose address is

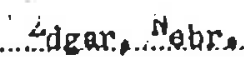

14th. Thiat the reiallon which the sibseriber to this affidavit benrs to sald registrant is that of

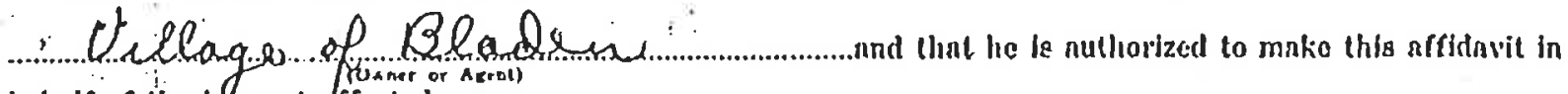
belinlf of thio inferesi difected.
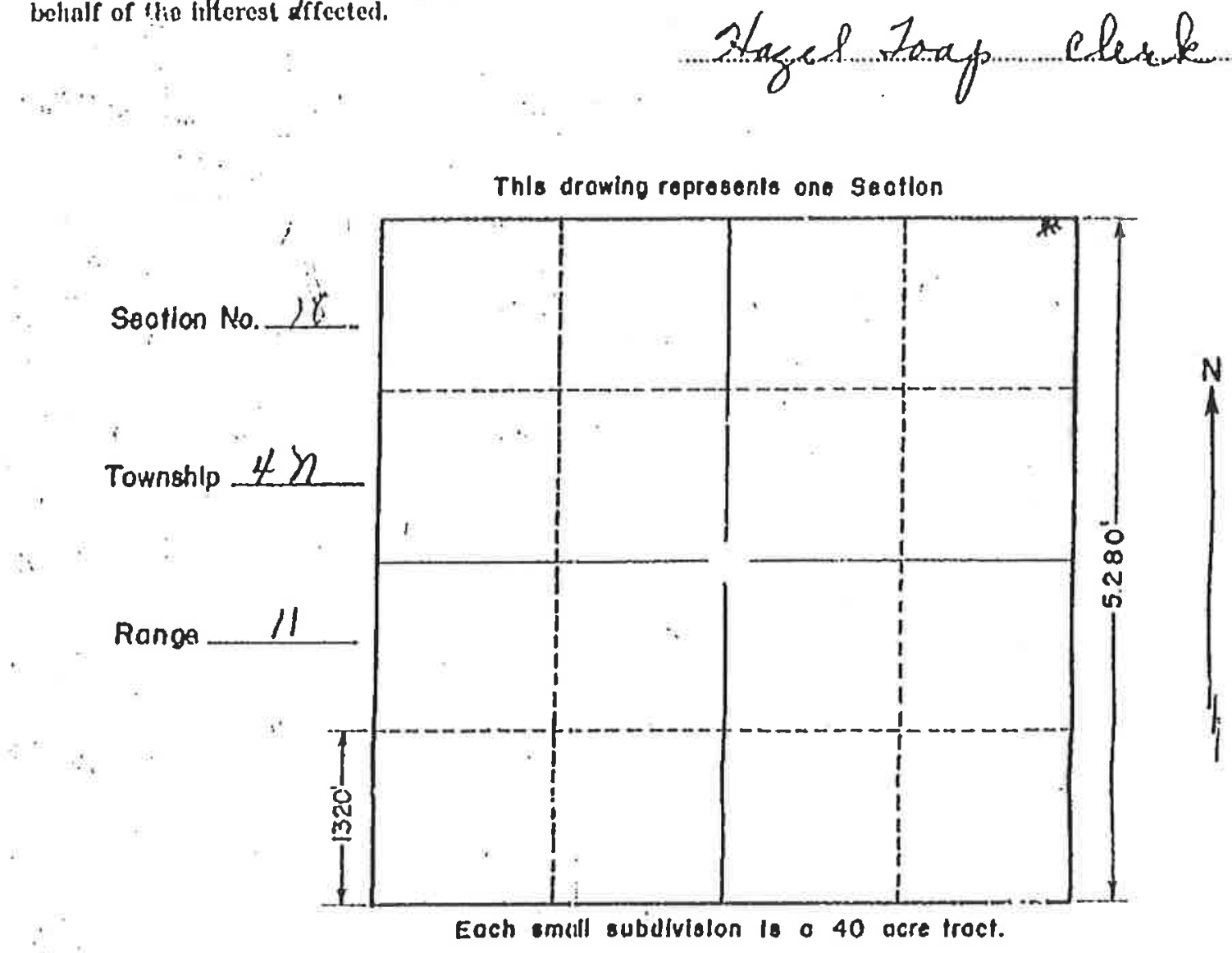

\section{State of Nebrsakn}

Ieparimenl of Water Resoures

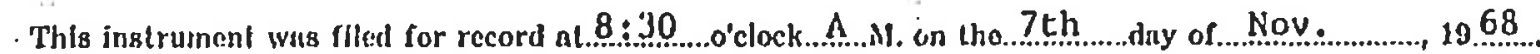
REPLACEMENI' WELI, Orf.g, f1lad feg. 14, 1967

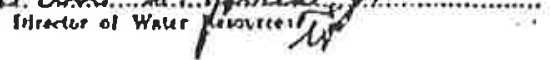




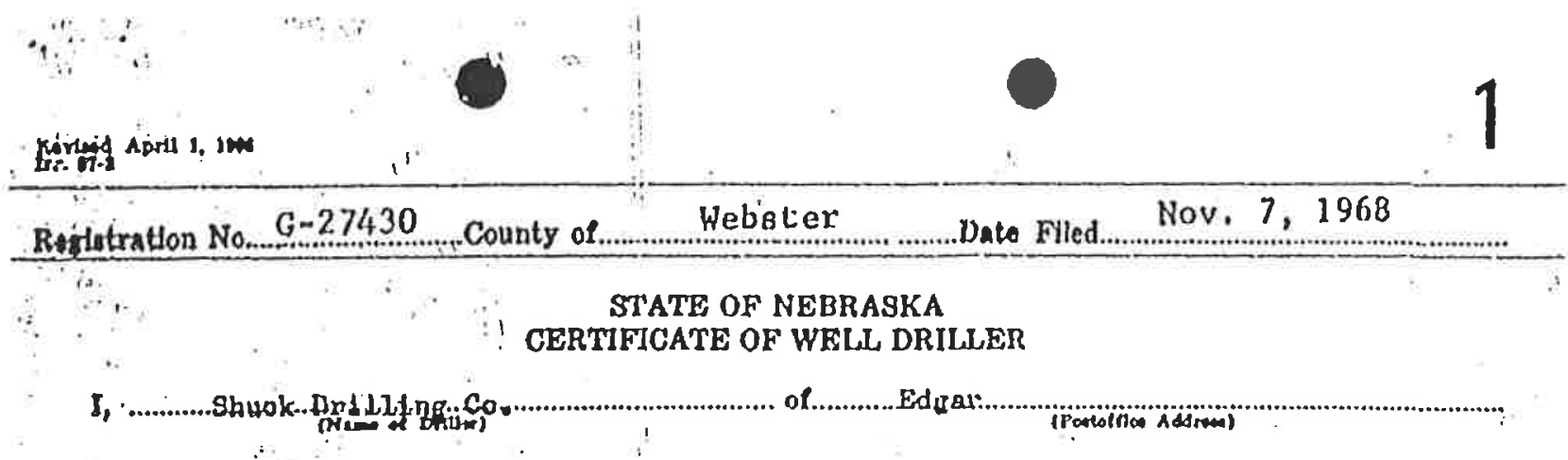

County of....clay.

State of...tighr. do hereby certify that:

1. I am the drllier of a well located on the... Quarter, isection No..................... Townihlp.....,.................North, Range...................... owned by.

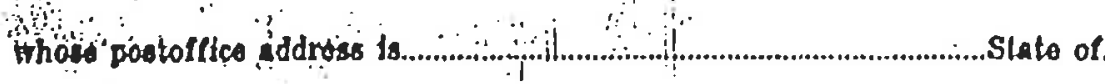

$\because$ That the drilling was begun on the. day of. $19 . . . . . .$. and complated on the........it................dny of. 19

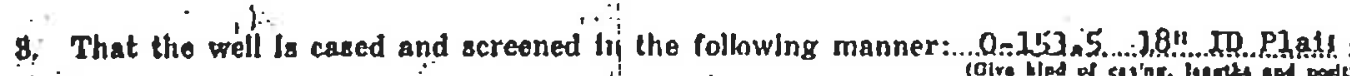

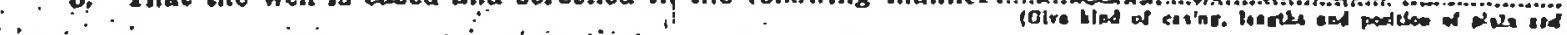

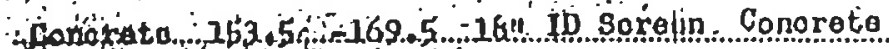

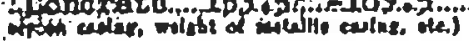

4. That the djameter of drilled hole is.....:36.........inches.

8. That.....Rovisso Ratory. type of dr|ling machinery was used.

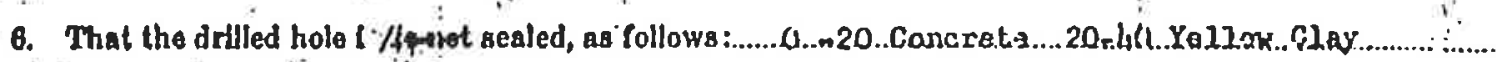
afond

$T_{i} \cdot$ That, the following is as iccurate log of the depth, thickness sont character of the different strate penetratod, and the location of water-bearing otrata:

DEPTHY IN FETYT

FROM. TO

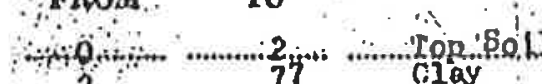

$77^{2}$ Cilay

77 Sand \& oravel

79 ..............

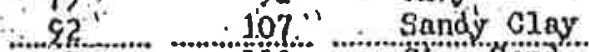

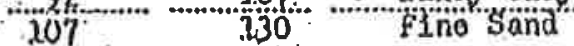

130 1......... Clay Some FIne Sand

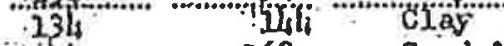

168 Sand \& Orave

168 172 viay

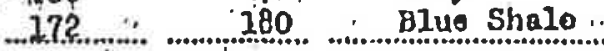

\section{MATERIAL DRILI,ED}

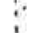


VULAGE OF BLADEN

ME-ADIN, NTIHASRA

Tho villago has a soound roll bit all tho Inforatation availabldis as

follon: :

H.W. iuartor of H.W. Ọtator Soction 1.8 Tomainiph Rango 11

Dopth $: 168 \mathrm{ft}$.

$146 \mathrm{Fl}, 20$ inohog to tụji of azroon.

21 foot 2 inofi soroon

$8 \%$ root wator in woll.

8;) feot to wator?

j.2 to 25 bowle, 1

750 gallons por n'mute.

Jakes from Jown board mecting manutes dited Qetakes 1930

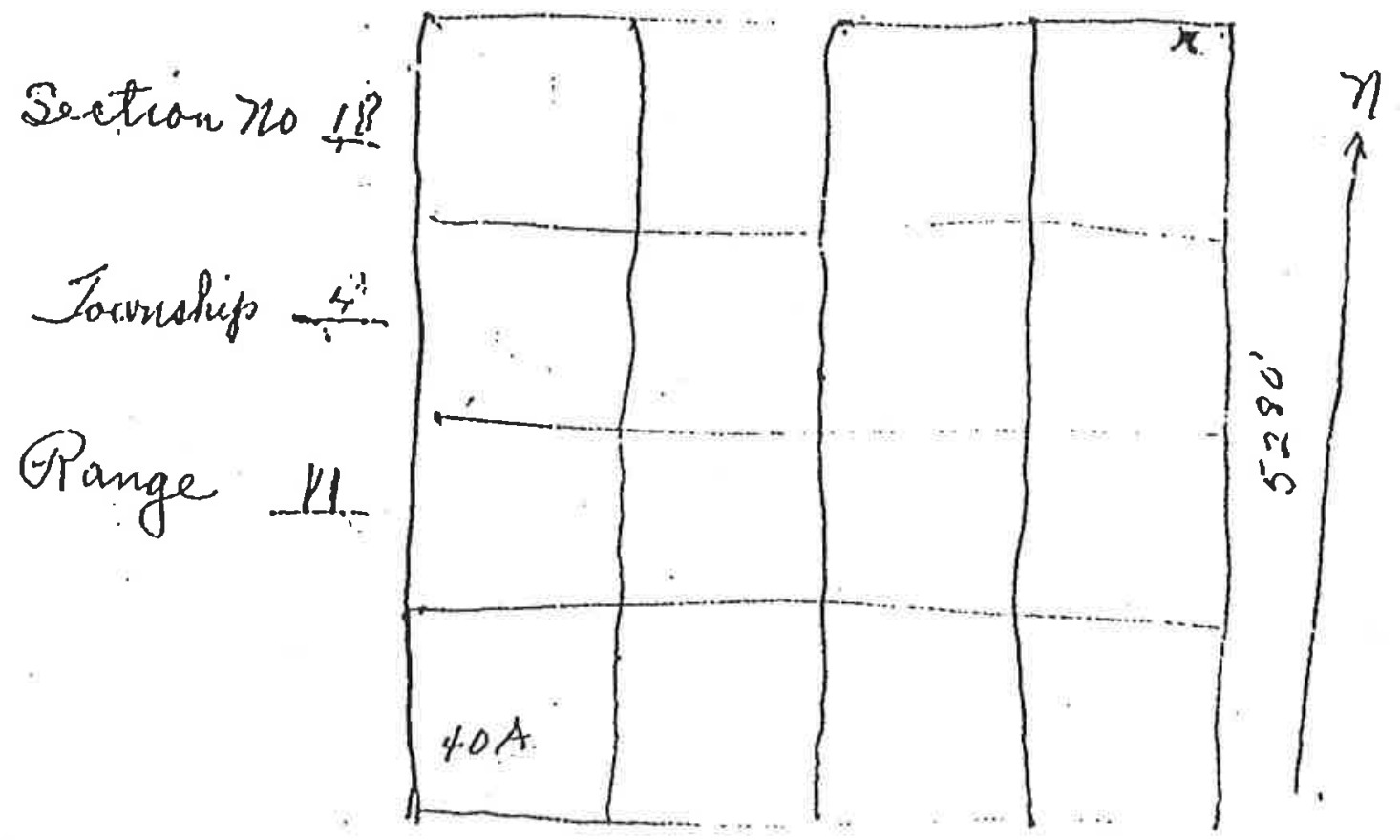

Appendix A, page 9 of 17 


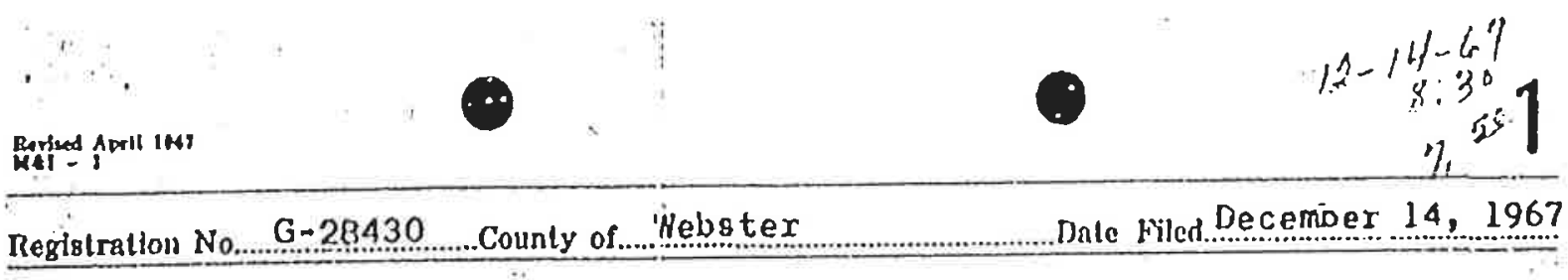

STATE OF NEBRASKA

MUNICIPAI, OR IHDUSTIIJAL IVEI, REGISTRATION

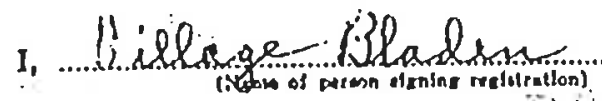

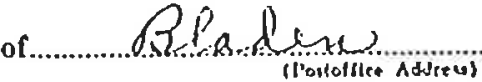

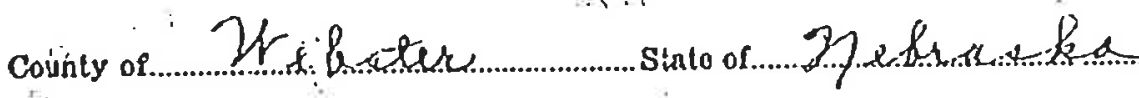
do hereby cerlify:

18t. That tho name of the ownor of tho imunjcipal (or) industrinl well registered herein is

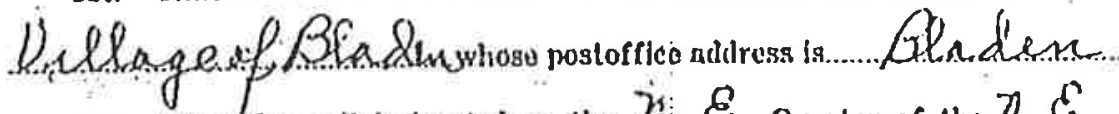

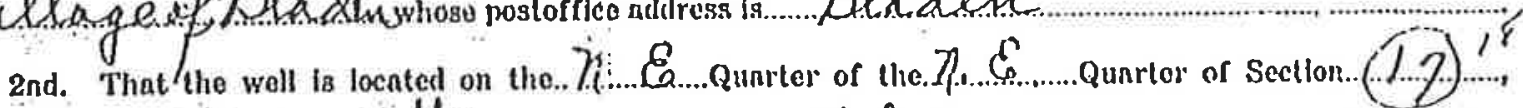

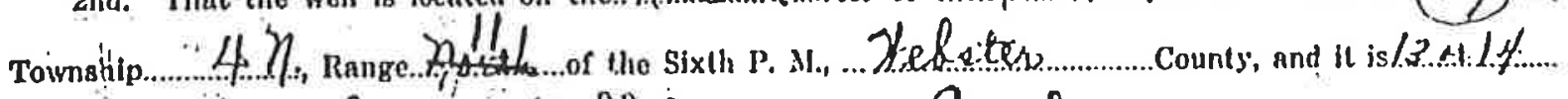

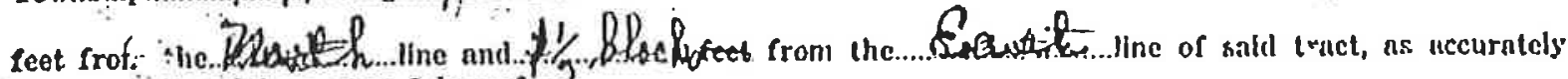
shown on the plat on page 2 hereof. 2

ard. 'That tho wall was installed for tho following purpose or phrposes:...

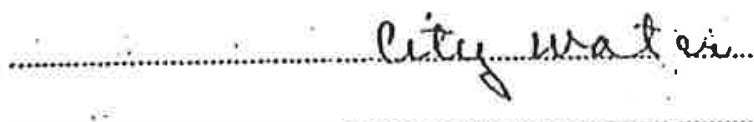

4th. That the capncity of snfl well under nomal ojerating cinditions is.....................galions mer minute.

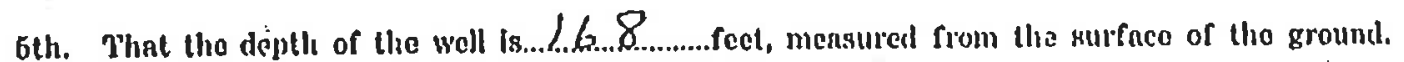

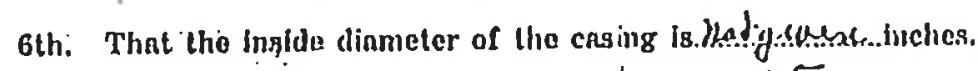

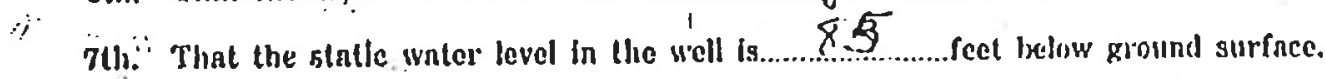

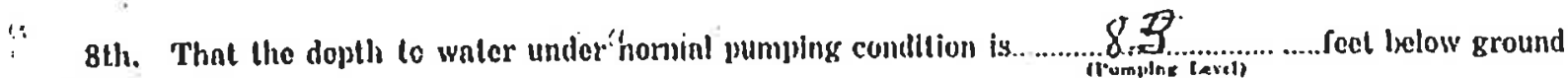
вurface.

9th. That the diameter of the pump colunn is. Inches. I'hnt the dinmeter of the...2.ta bowwl or bowls is....het.grititu. inclies.

10th. 'That the type and size of Impeller If' ns follows:

Itth. Thial the woll was comploted on or nlout tho

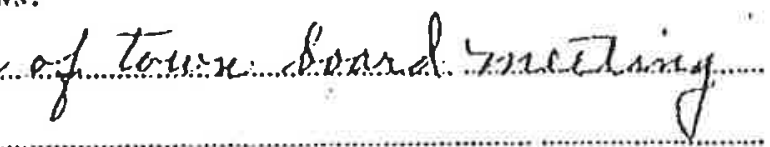

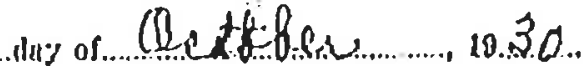


12th. That stlached hereto sue three coplus of the hat of tho well certified to by the triller of the well.

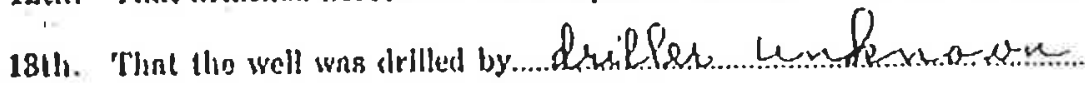
.wlost adliess is

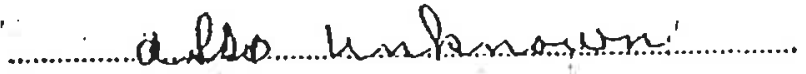

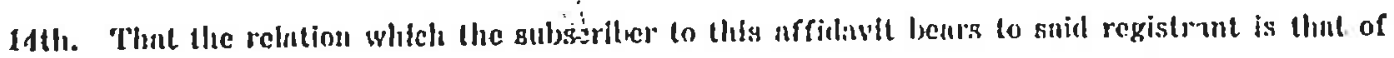

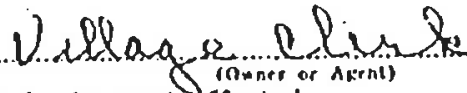

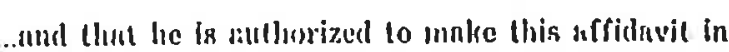
bolin!f of the interest affecterl.

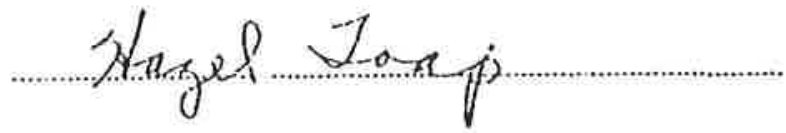

This diawling represente one Seoflon

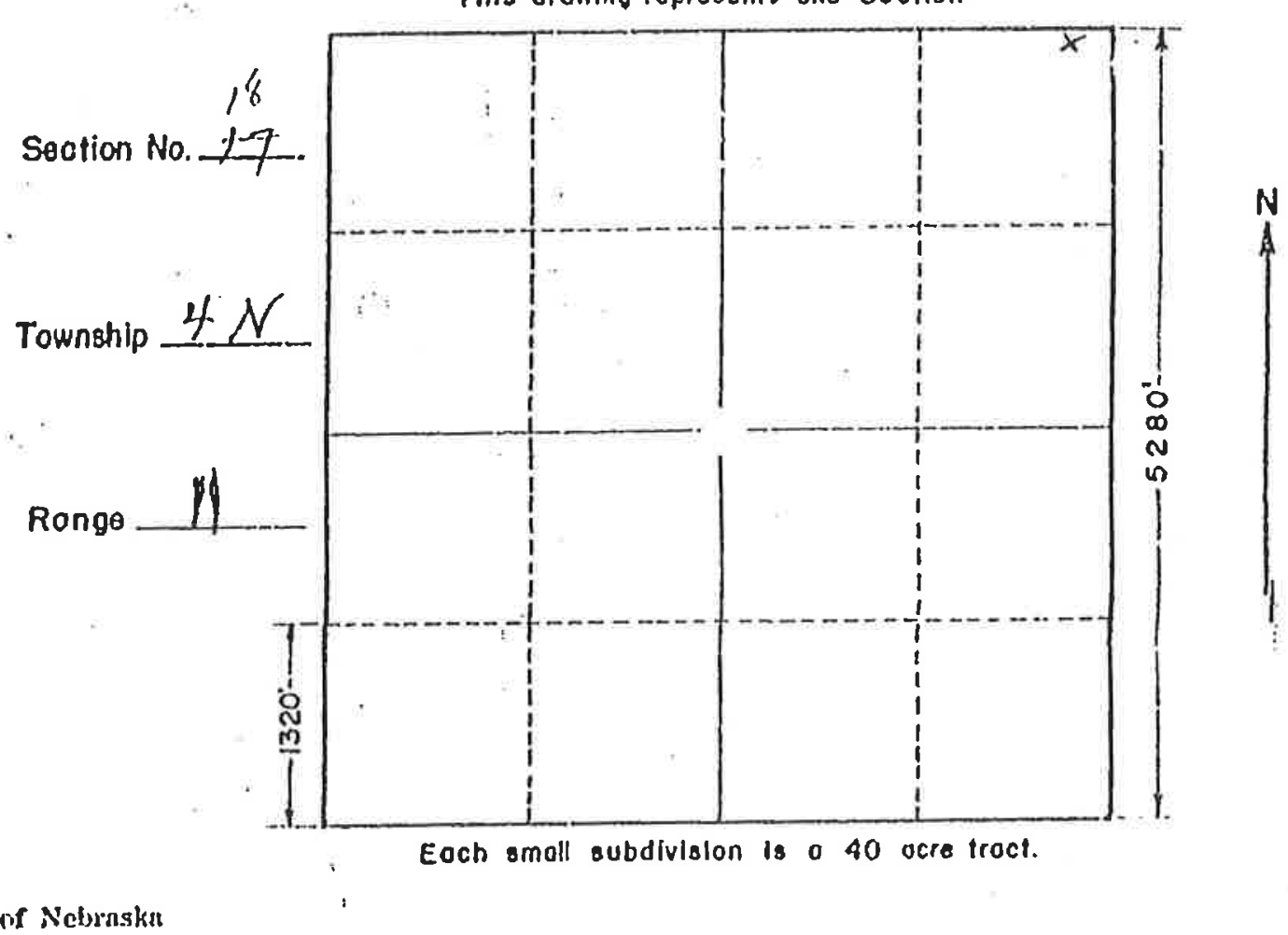

\section{Sinte of Nobriska}

\section{Deparinent of Wnter lesoures:}

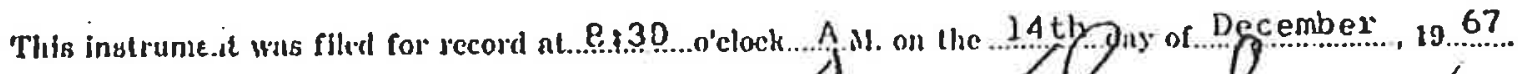




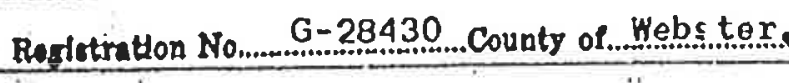
STATE OF NEBRASKA
OERTIFICATE OF WELL DRILIJK
STATE OF NEBRASKA
OERTIFICATE OF WELL DRILIJK

\section{OERTIFCATE OF WELh DRILرe:}

Date Fuled...December 14,1967

$x_{1}$ (Now on Drilion)

of $\because$

County of

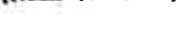

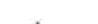
$\because$

1. I am tiso driller of a well located on the.

State of. .., do hereby certify that:

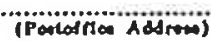

Tomihhlp....................North, Range....................... owned by.

whose postofflce address is

State of

2. Thist th: drilling was begun on the day of. 19........, and completed on Quarter, Section No

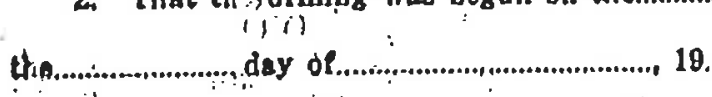

8. That this well is cased and screened In the tollowing manner:

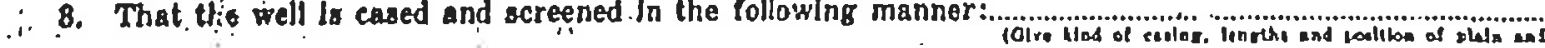

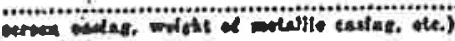

4. That the diameter of drilled hole is. Inches.

6. That "i

B: That thi drtllod hole is/lis not sealed, as follows: type of drilling machinery was ured.

7. That the following is an acaurate log of the depth, thickness and character of the different atrata penetrated, and the location of water-bearing strata:

DEPTH IN FEET.

FROM TO
MATERIAI, DRILLED

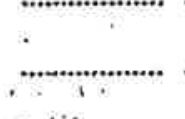

. . .

(1)

i.

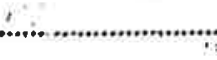

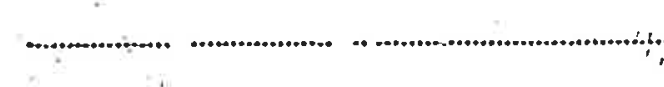

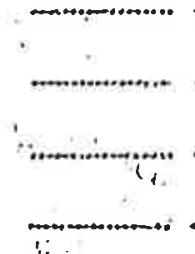

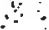

Date sloned

$\because \cdots+\cdots$

Drilim 


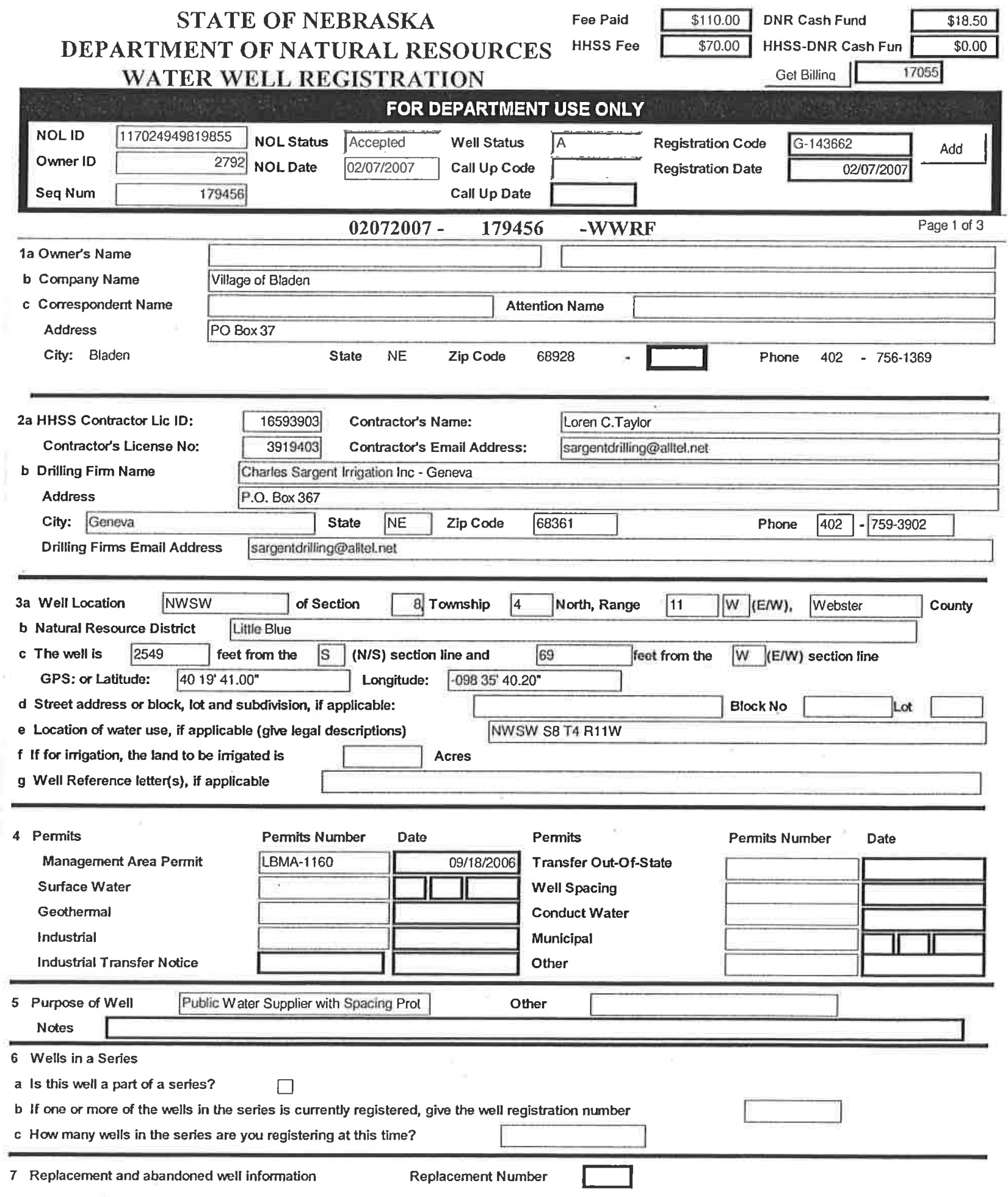




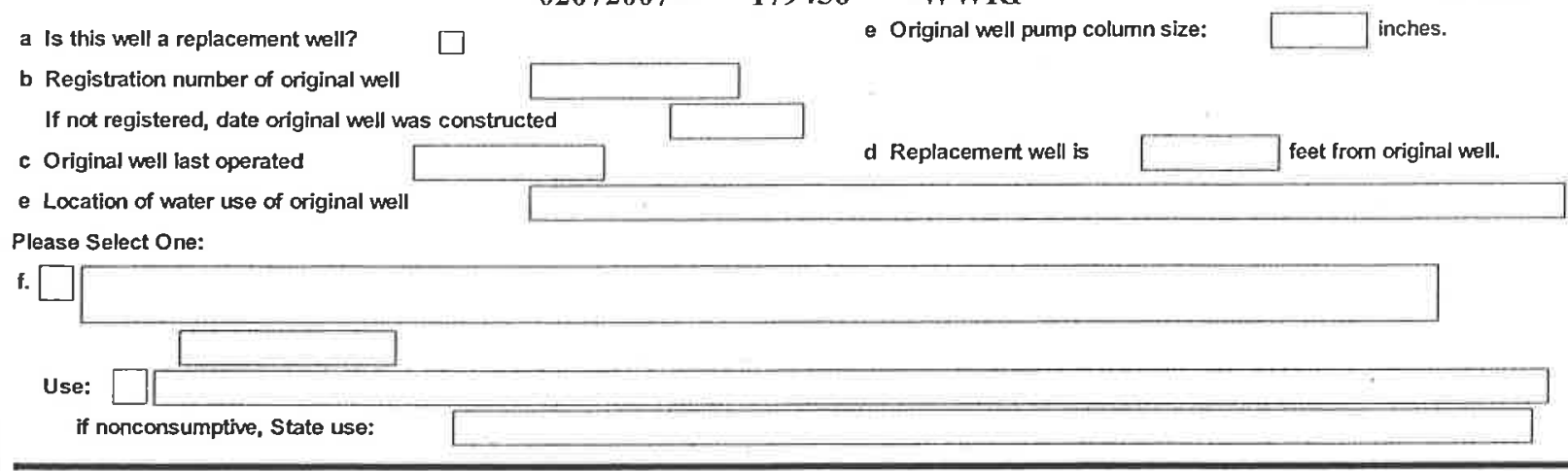

\section{Pump Information}

a Is pump installed at this time? $\checkmark$

Is pump installed by well owner in section 17

Else installed by pump installer.

b HHSS Instalfer's License ID.

Pump Installer's License No.

Pump Installer's Email Address

Pump Installer's Firm Name

Pump Installer's Firm Address

City: Geneva

Pump Installer's Firm Email Address

c Pumping Rate $\quad 450$ gallons per minute

d Drop pipe diameter $\quad 6$ inches

f Pumping equipment installed $01,11,2007$

$h$ This well will be used to pump less than $50 \mathrm{gpm}$

\begin{tabular}{|c|c|c|c|c|}
\hline \multirow{2}{*}{\multicolumn{2}{|c|}{$\frac{431529}{39454}$ Pump Installer's Name }} & \\
\hline & & Nathan A Jacobson & & \\
\hline \multicolumn{5}{|c|}{ sargentdrilling@alltel.net } \\
\hline \multicolumn{5}{|c|}{ Charles Sargent Irrigation, Inc } \\
\hline \multicolumn{5}{|l|}{ PO Box 367} \\
\hline State & Zip Code & $68361-0000$ & Phone & $402 \cdot 759-3902$ \\
\hline
\end{tabular}

Is pump installed by contractor in section 2 ?

$\checkmark$

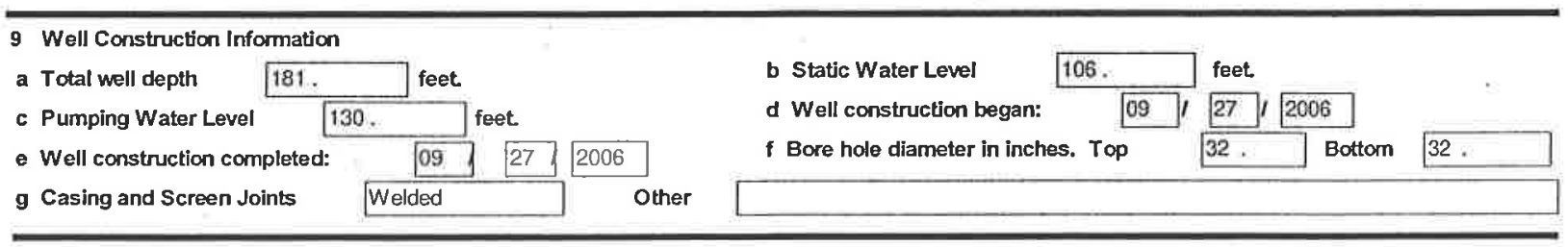

10 Well Construction (Casing and Screen)

\begin{tabular}{|c|c|c|c|c|c|c|c|c|c|}
\hline Fr Deplh & To Depth & Case Scrn & In Diam & Out Diam & Thickness & Scrn Slot Size & Material & Trade name & NOLID \\
\hline 0 & 152 & casing & 15.25 & 16 & .375 & & iteel & Livingston & 117024949819 \\
\hline 152 & 169 & screen & 15.25 & 16 & .375 & .090 & Steel & Johnson Ag & 117024949819 \\
\hline 169 & 181 & casing & 15.25 & 16 & .375 & & iteel & Sump & 117024949819 \\
\hline
\end{tabular}

11 Well Construction (Grout and Gravel)

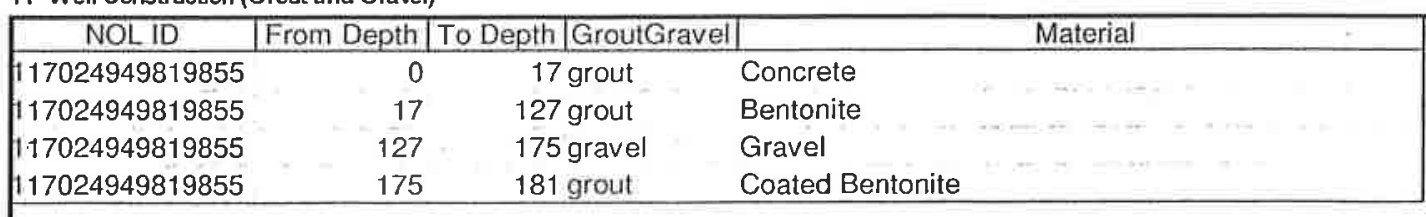


$02072007-179456 \quad$-WWRF Page 3 ol 3

12 Geolog Material Logged

\begin{tabular}{|c|r|c|c|}
\hline NOL ID & From Depth & To Depth & Description \\
\hline 117024949819855 & 0 & 20 Topsoil and clay \\
117024949819855 & 20 & 88 Clay \\
117024949819855 & $88:$ & 120 Medium to coarse sand with clay layers \\
117024949819855 & 120 & 137 Clay with medium to coarse sand \\
117024949819855 & 137 & 140 Medium to coarse sand with trace of fine gravel \\
117024949819855 & 140 & 145 Medium to coarse sand \\
117024949819855 & 145 & 168 Coarse sand with fine to medium gravel \\
117024949819855 & 168 & 181 Ocher and shale \\
\hline
\end{tabular}




\section{APPLICATION FOR A PERMIT TO CONSTRUCT A WATER WELL IN THE LIT1 _ _ BLUE NATURAL RESOUR、 :S DISTRICT}

1. Name: Village of Bladen (2792)

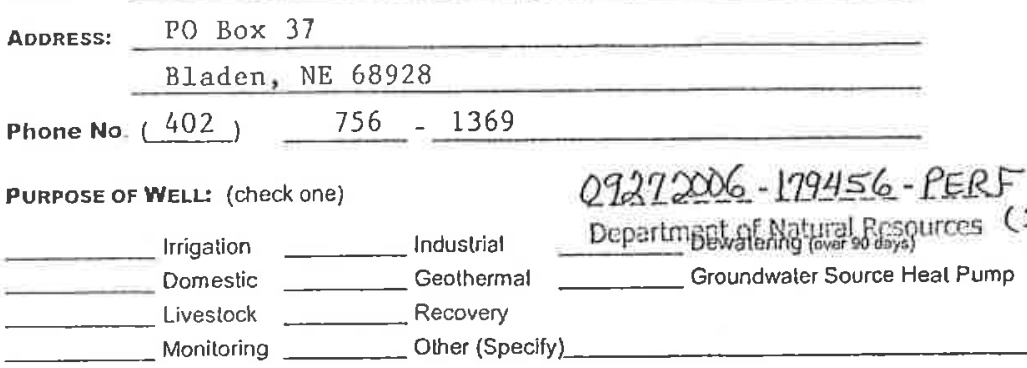

DWR \& NRD Use Only

Permil No: $\angle B M A-1160$

Reg. No. $6-143662$

IDENTIFY THE Location OF THE WELL:

Webster_County, Section (by quarter) 8

Townshlp_____ North Range____ 11 E_____ East of West

Well is _2690 feet from the Norta/South Section Line or Latilude __________ North

and 50 feel from the Earfwest) Section Line or Longitude W_ West

The box at the right represents one square mile, (section). Indicalo with an " $X$ ", the proposed location of the well, please highlight the proposed water-use area. If water is to be used outside the above-written legal description. give legal description of water-use area below. Section (by quarter) Township North, Range EastWes!

4. IRRIGATION WELLS:

How many acres will be irrigaled? Type of irrigation system? Will system be Will flow meter be used on the well? Will the well be used in a system with other wells? ___ Yes___ No? If yes, how Many? Will fertilizer, chemicals or animal waste be applied through the system ____ Yes N____ No?

5. REPLACEMENT AND ABandonment Well INFORMation:

\section{SEP 132006}

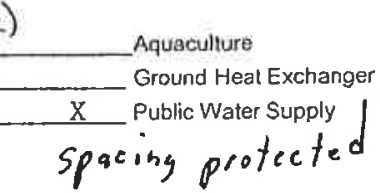
Is this a replacement well?
Yes N N
Registration Number of well to be replaced:
Well to be replaced was last operaled on
Replacement well is feet from original well.
Completion of original well decommission on
Replacement well must water the same tracl of land as the decommissioned well.

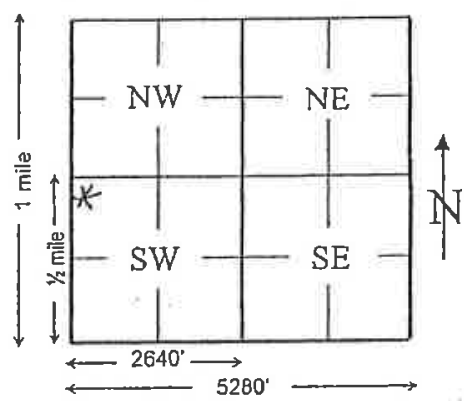

6. SPECIfications of WELL AND PUMP:

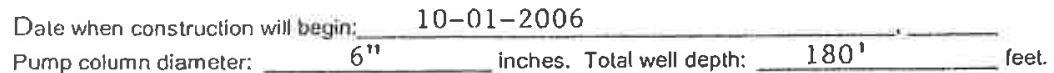

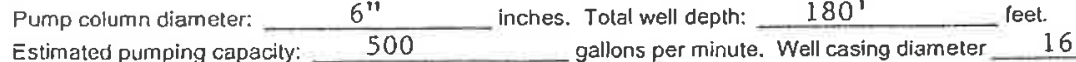

Please atlach test hole log, if available. Name of Well Driller: Sargent Drilling

7. I certify lhat I am familiar with the information contained in this application and its restriclions, rules and land regulations; and that to the besl of my knowledge and belief, such information is true, complete and accurate.

This form musl be completed in full and be accompanied by a non-refundable $\$ 50.00$ filing fee payable to the Little Blue Nalural Resources District.
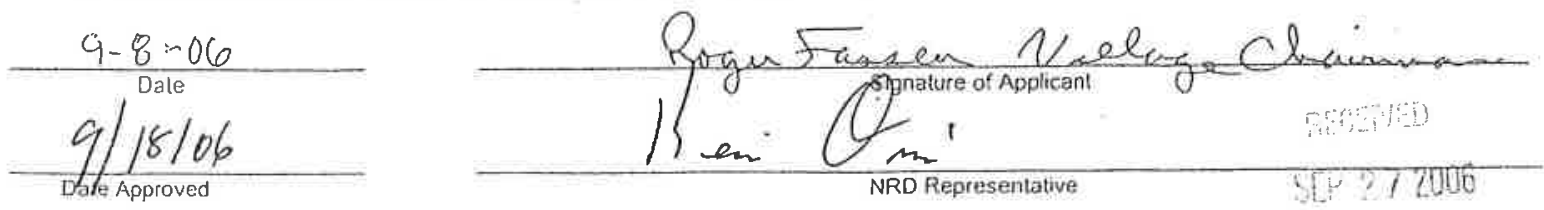

See Other Side for Important Permit Restrictions, Rules and Regulations!!!!! 
This form must be completed in full and be accompanied by a non-refundable $\$ 50,00$ filing lee payable to the Little Blue Natural Resources District. Fonward this application and filing fee to:

Litlle Blue Natural Resources District

PO Box 100

Davenport, NE 68335

(402) $364-2145$

Please take the time and fill out the information correctly. An incomplete or defective application will be returned by lhe District, wilh 60 days being allowed for resubmission. All permits shall be issued by the Dislricl with conditions attached or denied not later than 30 days after receipl of a complete and properly prepared application.

\section{PERMIT RESTRICTIONS}

1. Well permits are required prior to consiruction or a late fee of $\$ 250 . \underline{00}$ will be assessed.

2. Permits are not required for test holes, temporary dewatering wells (less than 90 days), or wells designed to pump 50 gallons per minute or less.

3. Construction of the water well authorized by this permit must be completed not later than one year after the issuance date of this permit. If a stay on water well permils or a moratorium on well construction is issued prior to that one year date of expiration, the permit shall expire immediately upon the date of issuance of that siay or moratorium, unless construction of the well has been commenced prior to the issuance of that stay or moratorium.

4. Irrigation wells authorized by this permit may not be constructed closer than 1000 feet to any existing well having a capacily of 50 gallons per minute or more. This applies to all irrigation wells, even if registered to the same owner. Other permitted wells with spacing protection will be regulated by state statutes.

5. According to State law \$46-637, water wells may not be drilled wilhin 50 feet of a streambank without first getling a surface water right for that stream from the Department of Natural Resources.

6. Replacement wells do need a permit from the Little Blue NRD. A replacement well is one which replaces an abandoned water well that has been operated within the last three years, and is constructed to water the same tract of land as the abandoned water well. If the well is being replaced, it must be properly abandoned within according to state guidelines. A copy of these guidelines is available from the Little Blue NRD.

All new or replacement water welis constructed in the district are required to be sampled for nitrates upon completion.

A. Municipalities which develop a new public water well shall submit a copy of that well's initial water quality test results to the district within 30 days of receipt of such results from the Department of Health and Human Services.

B. The sample for all non-municipal wells shall be collected by the owner, operator or farm manager no sooner than 30 days, nor later than 60 days after activation of the well.

8. The Little Blue NRD requires that all new non-domestic water wells designed to pump 50 gallons per minute or more be constructed with 80 inches of free space in the pump discharge or piping configuration to accommodate a flow measurement device if required in the future.

9. Any person who commences or causes construction of such a well for which the required permit has not been obtained, or who knowingly furnishes false information regarding such permit, shall be guilty of Class iV misferneanor, $\{\S 46-$ 602.01\}.

10. This permit does not register the well with the Department of Natural Resources. All wells are required to be registered with the State Department of Natural Resources within 30 days after the well is completed.

If possible, mark the well site in the field with a flag.

\section{Comments/Restrictions}

Revised 07/06 


\section{Appendix B:}

Nebraska Wellhead Protection Area Map for the Bladen Public Water Supply System and Data Used to Construct the Map 


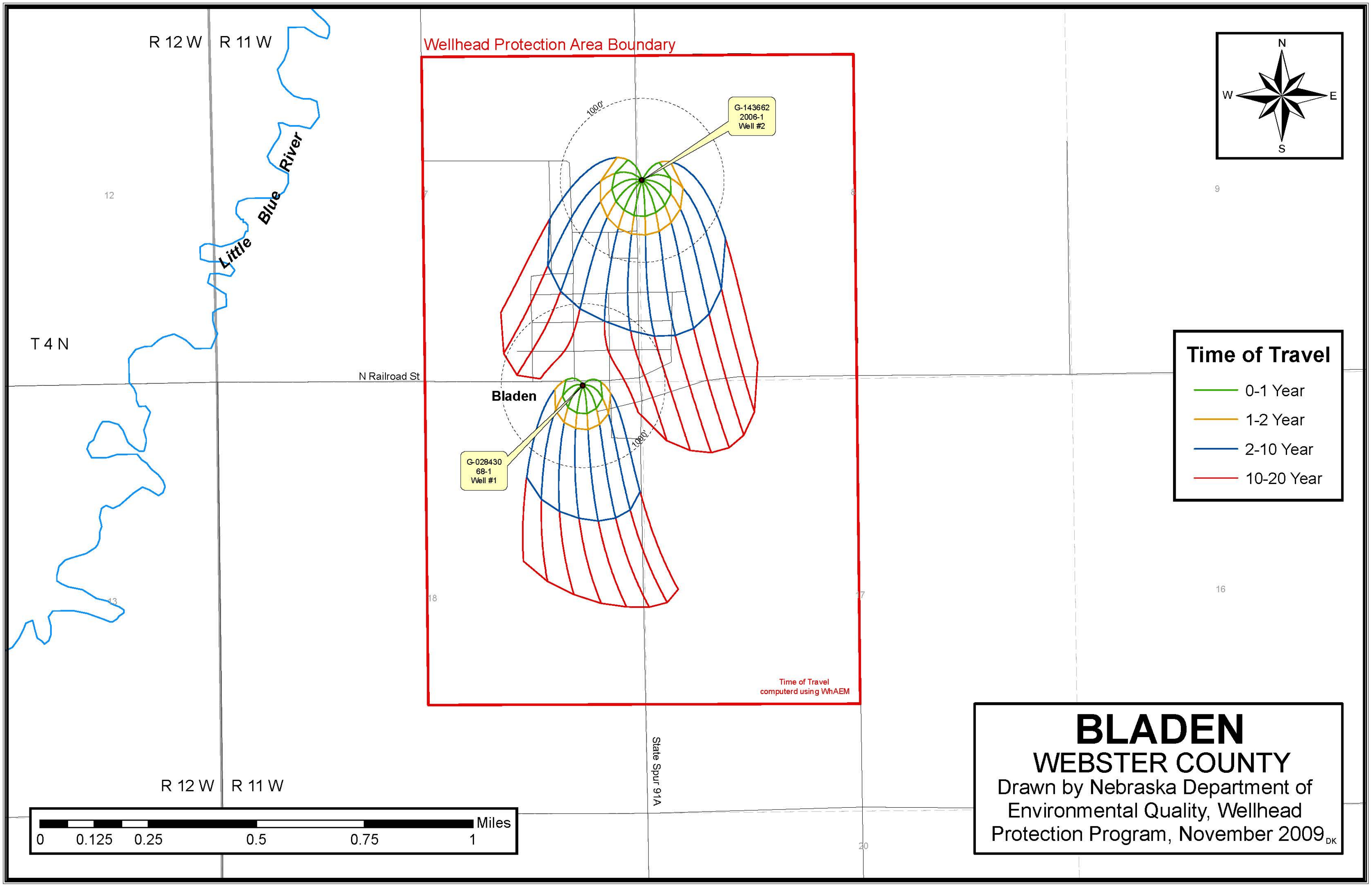




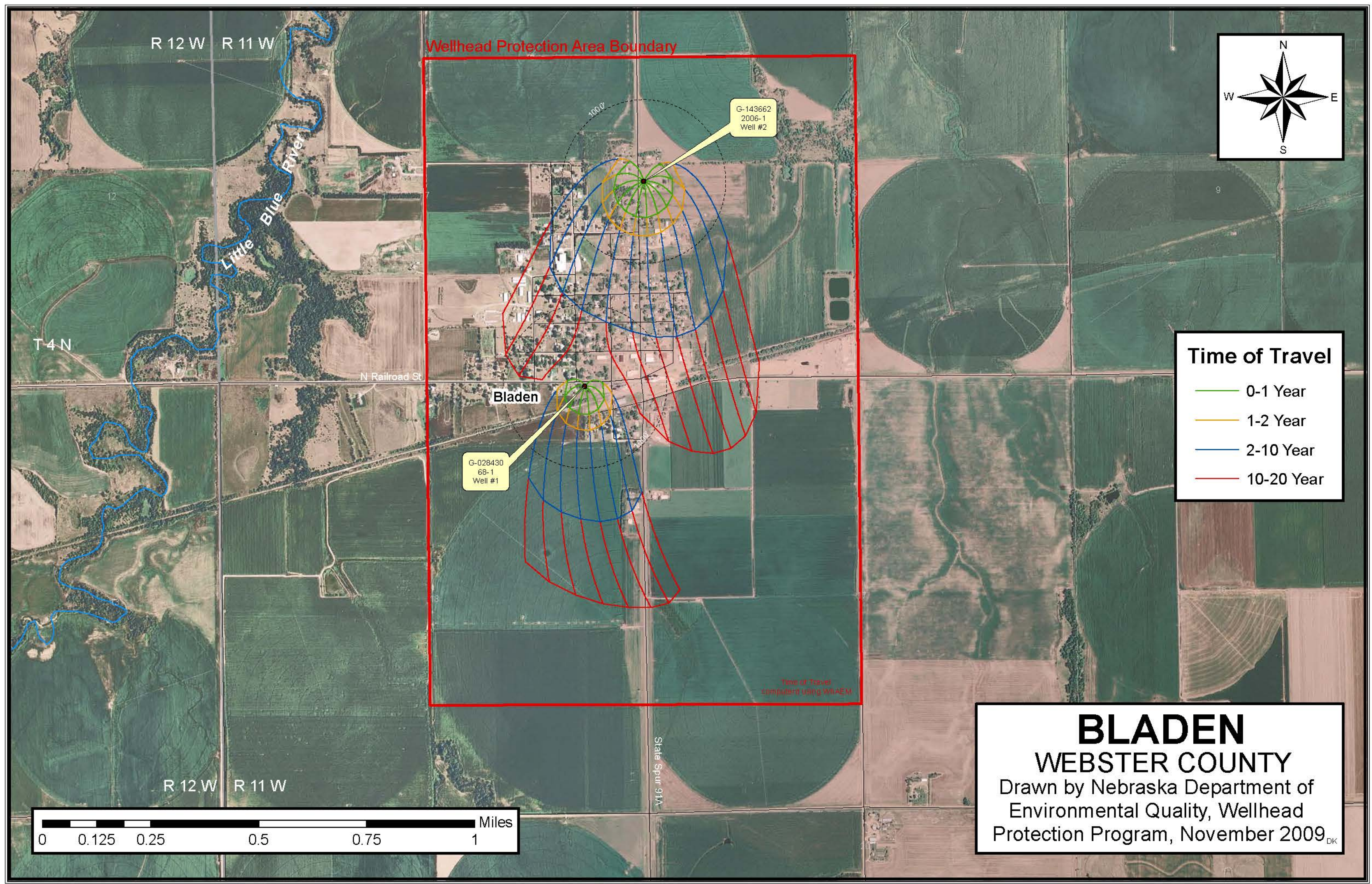


WhAEM Data Sheet

\begin{tabular}{|c|c|c|c|c|c|}
\hline System Name: & Village of Bladen & & & & \\
\hline \multicolumn{6}{|l|}{ Base Maps: } \\
\hline Hydrography (HY) & dnrsteams & & & & \\
\hline Roads (RD) & rds $181-83$ & & & & \\
\hline Railroads (RR) & rail181-83 & & & & \\
\hline \multirow{6}{*}{$\begin{array}{l}\text { Element } \\
\text { Wells } \\
\end{array}$} & & Well & Well & Well & Well \\
\hline & Name & Well \#1 & Well \#2 & & \\
\hline & Pump Rate ( $\mathrm{ft}^{3} /$ day) & 3242 & 6489 & & \\
\hline & Radius (ft) & 1 & 1 & & \\
\hline & Starting Elevation (ft) & 1817 & 1817 & & \\
\hline & \# of Pathlines & 8 & 12 & & \\
\hline \multirow[t]{6}{*}{ Line Sink (river/lake) } & Name & Head change & Units & & \\
\hline & Little Blue River & $1800-1650$ & feet & & \\
\hline & Platte River & $2145-1820$ & feet & & \\
\hline & Republican River & $1850-1560$ & feet & & \\
\hline & & & feet & & \\
\hline & & & feet & & \\
\hline \multicolumn{6}{|l|}{ Head-Specified Wells } \\
\hline Wells & Head & & Well & Head & \\
\hline USGS 401459098325801 & 1825 & feet & USGS401928098292502 & 1912 & feet \\
\hline USGS 401819098385101 & 1903 & feet & USGS402248098273801 & 2016 & feet \\
\hline USGS 401905098432101 & 1937 & feet & USGS402238098244301 & 1996 & feet \\
\hline USGS 401928098292501 & 1915 & feet & USGS402224098290901 & 1828 & feet \\
\hline G-137284 & 1870 & feet & G-128304 & 1991 & feet \\
\hline G-132192 & 1869 & feet & G-136039 & 1997 & feet \\
\hline G-033729 & 1880 & feet & G-128302 & 1820 & feet \\
\hline G-122286 & 1875 & feet & G-126655 & 1885 & feet \\
\hline G-122287 & 1866 & feet & G-029486 & 1832 & feet \\
\hline G-137573 & 1878 & feet & G-112780 & 1851 & feet \\
\hline G-122243 & 1905 & feet & G-126876 & 1829 & feet \\
\hline G-134710 & 1867 & feet & G-122600 & 1822 & feet \\
\hline G-145511 & 1878 & feet & G-041562 & 2013 & feet \\
\hline G-140359 & 1882 & feet & G-092910 & 1927 & feet \\
\hline G-129581 & 1894 & feet & G-017957 (LBNRD) & 1827 & feet \\
\hline Unl 23-B-81 & 1875 & feet & G-030035 (LBNRD) & 1941 & feet \\
\hline G-091250 & 1902 & feet & G-034223 (LBNRD) & 1906 & feet \\
\hline G-135806 & 1887 & feet & G-007049 (LBNRD) & 1914 & feet \\
\hline G-150286 & 1895 & feet & G-030745 (LBNRD) & 1913 & feet \\
\hline G-110447 & 1899 & feet & G-023420 (LBNRD) & 2001 & feet \\
\hline \multirow[t]{2}{*}{ USGS401916098252101 } & 1915 & feet & G-033392 (LBNRD) & 1997 & feet \\
\hline & & & G-047380 (LBNRD) & 1819 & feet \\
\hline Model & Base Elevation & 1817 & feet & & 90 \\
\hline \multirow[t]{4}{*}{ Aquifer } & Thickness (saturated) & 28 & feet & & \\
\hline & Hydraulic Conductivity & 168 & $\mathrm{ft} / \mathrm{day}$ & & \\
\hline & Porosity & 0.2 & & & thata \\
\hline & Iterations & 4 & & 180 & 17 \\
\hline \multirow[t]{3}{*}{ Tracing } & Maximum Travel Time & $7305,3652,730,365$ & days & & / \\
\hline & Compute Particle Paths & $x$ & & & \\
\hline & Use Default Step Size & $x$ & & & 270 \\
\hline & & & & & \\
\hline & & & & & \\
\hline & & & & & \\
\hline & & & & & \\
\hline & & & & & \\
\hline
\end{tabular}




\section{Appendix C:}

Geologic Logs and Well Information for Private and Public Water Wells and State Test Holes Used in Construction of Geologic Cross Sections A-A', B-B', and C-C' 


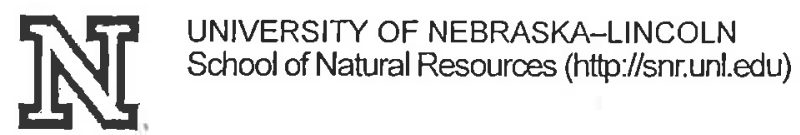

\section{Test Hole Data}

Download tables of:

General Character Lithology Stratigraphy

- General Character (javascript:void(null);)

- Lithology (javascript:void(null);)

- Stratigraphy (javascript:void(null)i)

\section{General Character}

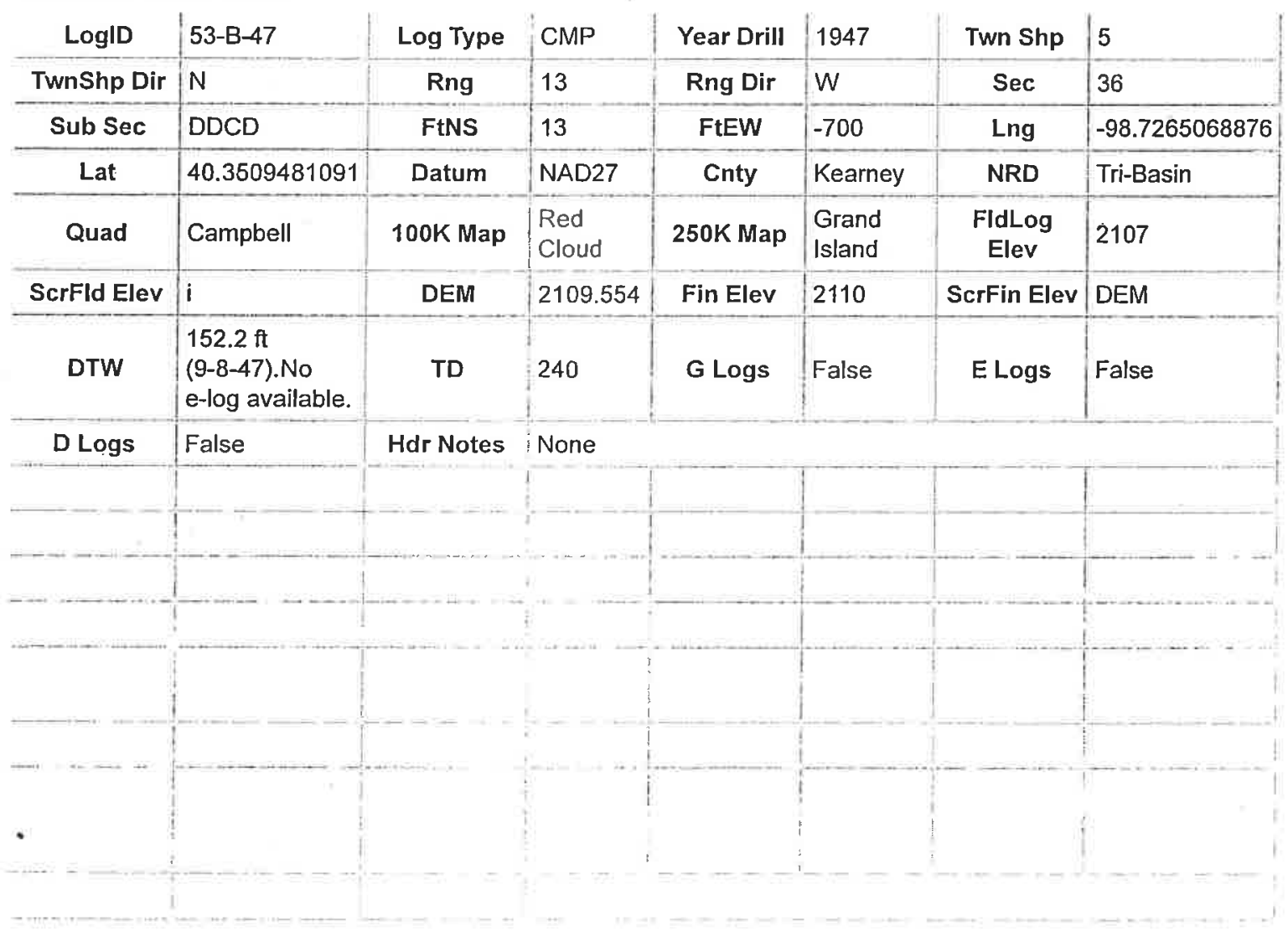

\section{Lithology}




\begin{tabular}{|c|c|c|c|c|c|}
\hline LogID & LithUnit & Descrpt & DepFm & DepTo & Notes \\
\hline $53-B-47$ & Soil & silt, slightly clayey, medium brown gray & 0 & 0.5 & None \\
\hline $53-B-47$ & Silt & moderately clayey, buff gray & 0.5 & 3.5 & None \\
\hline $53-B-47$ & Silt & $\begin{array}{l}\text { slightly clayey, light buff gray, slight tan } \\
\text { tint below } 12.5 \mathrm{ft} \text {, contains a few limy } \\
\text { nodules }\end{array}$ & 3.5 & 14.5 & None \\
\hline $53-B-47$ & Silt & $\begin{array}{l}\text { soil-like, very slightly clayey to slightly } \\
\text { sandy, dark reddish brown, texture of } \\
\text { sand is very fine to fine }\end{array}$ & 14.5 & 21 & None \\
\hline $53-B-47$ & Silt & moderately sandy, brownish tan & 21 & 25 & None \\
\hline $53-B-47$ & Silt & $\begin{array}{l}\text { slightly clayey to slightly sandy, light } \\
\text { brownish tan with gray tint }\end{array}$ & 25 & 35 & None \\
\hline $53-B-47$ & Silt & $\begin{array}{l}\text { moderately sandy, light brownish tan to } \\
\text { tannish gray, texture of sand is very fine } \\
\text { with a trace of fine, contains a very } \\
\text { calcareous zone from } 67 \text { to } 69 \mathrm{ft}\end{array}$ & 35 & 70 & None \\
\hline $53-B-47$ & Silt & $\begin{array}{l}\text { sandy, light brownish tan, texture of } \\
\text { sand is very fine to medium with a trace } \\
\text { of coarse }\end{array}$ & 70 & 77 & None \\
\hline $53-B-47$ & Silt & $\begin{array}{l}\text { moderately to very sandy, brownish tan, } \\
\text { texture of sand is very fine to medium, } \\
\text { moderately calcareous from } 77 \text { to } 85 \mathrm{ft} \text {, } \\
\text { contains limy concretions from } 77 \text { to } 80 \\
\mathrm{ft} \text { and from } 95 \text { to } 100 \mathrm{ft}\end{array}$ & 77 & 100 & None \\
\hline $53-B-47$ & Sand & $\begin{array}{l}\text { silty, light tan to buff gray, very fine to } \\
\text { coarse texture }\end{array}$ & 100 & 114.5 & None \\
\hline $53-B-47$ & Marl & $\begin{array}{l}\text { moderately sandy, white, texture of } \\
\text { sand is very fine to medium }\end{array}$ & 114.5 & 120 & None \\
\hline $53-B-47$ & Marl & light gray, contains volcanic ash & 120 & 124 & None \\
\hline $53-B-47$ & Sand & $\begin{array}{l}\text { silty, marly, in part siliceous, light gray, } \\
\text { very fine to medium texture }\end{array}$ & 124 & 132.5 & None \\
\hline $53-B-47$ & Marl & $\begin{array}{l}\text { sandy, white, texture of sand is very } \\
\text { fine to medium sand }\end{array}$ & 132.5 & 138 & None \\
\hline $53-B-47$ & Silt & $\begin{array}{l}\text { sandy, moderately calcareous, olive } \\
\text { gray, texture of sand is very fine to } \\
\text { medium, slightly calcareous and in part } \\
\text { indurated and more sandy below } 140 \mathrm{ft}\end{array}$ & 138 & 145 & None \\
\hline $53-B-47$ & Silt & $\begin{array}{l}\text { sandy, to silty sand, very slightly } \\
\text { calcareous, very light olive gray, texture } \\
\text { of sand grades from very fine to } \\
\text { medium, slightly consolidated, grading } \\
\text { more sandy and coarser with depth }\end{array}$ & 145 & 158 & None \\
\hline $53-B-47$ & Sand & $\begin{array}{l}\text { slightly silty, light buff gray, very fine to } \\
\text { coarse texture }\end{array}$ & 158 & 163 & None \\
\hline $53-B-47$ & Sand & $\begin{array}{l}\text { silty, marly, light gray, very fine to } \\
\text { medium from texture }\end{array}$ & 163 & 165.5 & None \\
\hline
\end{tabular}




\begin{tabular}{|c|c|c|c|c|c|}
\hline $53-B-47$ & Clay & $\begin{array}{l}\text { silty to slightly sandy, reddish tan and } \\
\text { greenish gray, contains rounded limy } \\
\text { fragments }\end{array}$ & 165.5 & 170 & None \\
\hline $53-B-47$ & Silt & $\begin{array}{l}\text { slightly clayey to very sandy, in part } \\
\text { marly, light olive gray }\end{array}$ & 170 & 175 & None \\
\hline $53-B-47$ & Clay & $\begin{array}{l}\text { silty to very sandy, tannish gray, texture } \\
\text { of sand is fine to coarse, in part } \\
\text { contains reworked material }\end{array}$ & 175 & 180 & None \\
\hline $53-B-47$ & Sand & $\begin{array}{l}\text { silty, very light brownish gray, fine to } \\
\text { coarse texture, contains fossil seeds } \\
\text { and reworked limy fragments }\end{array}$ & 180 & 185 & None \\
\hline $53-B-47$ & Sand & $\begin{array}{l}\text { slightly silty, very light brownish gray, } \\
\text { texture grades from very fine to very } \\
\text { coarse, contains some reworked limy } \\
\text { material }\end{array}$ & 185 & 190 & None \\
\hline $53-B-47$ & Silt & $\begin{array}{l}\text { moderately sandy, and sand, } \\
\text { interbedded, brownish gray, texture of } \\
\text { sand is very fine to very coarse with a } \\
\text { trace of fine to medium gravel, contains } \\
\text { some calcareous spots }\end{array}$ & 190 & 195 & None \\
\hline $53-B-47$ & Sand & $\begin{array}{l}\text { light brownish gray with pink and a } \\
\text { trace of light green grains, texture } \\
\text { grades from very fine to very coarse } \\
\text { with a trace of fine gravel }\end{array}$ & 195 & 219 & None \\
\hline $53-B-47$ & Silt & $\begin{array}{l}\text { very sandy to slightly clayey, yellowish } \\
\text { brown, contains a few rounded limy and } \\
\text { limonitic granules }\end{array}$ & 219 & 220 & None \\
\hline $53-B-47$ & Silt & $\begin{array}{l}\text { clayey to slightly sandy, yellowish } \\
\text { brown, modmoderately sandy to } \\
\text { gravelly below } 224.5 \mathrm{ft}\end{array}$ & 220 & 226.5 & None \\
\hline $53-B-47$ & Clay shale & $\begin{array}{l}\text { black, contains occasional thin } \\
\text { ironstone layers }\end{array}$ & 226.5 & 240 & None \\
\hline
\end{tabular}


LogID

LithUnit

Descrpt

DepFm DepTo

Notes

\section{Stratigraphy}

\begin{tabular}{|c|c|c|c|c|c|c|c|}
\hline LogID & Sys & Ser & Grp & Frm & Mem & DepFm & DepTo \\
\hline $53-B-47$ & Quaternary & & & & & 0 & 114.5 \\
\hline $53-B-47$ & Tertiary & Miocene & Ogallala & & & 114.5 & 219 \\
\hline $53-B-47$ & Cretaceous & $\begin{array}{l}\text { Upper } \\
\text { Cretaceous }\end{array}$ & Montana & Dierre & & 219 & 240 \\
\hline
\end{tabular}

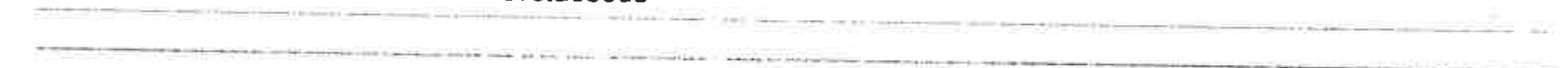




\section{Test Hole Data}

Download tables of:

General Character Lithology : Stratigraphy Download available G-Logs

- General Character (javascript:void(null);)

- Lithology (javascript:void(null);)

- Stratigraphy (javascript:void(null);)

\section{General Character}

\begin{tabular}{|c|c|c|c|c|c|c|c|}
\hline LogID & 23-B-81 & Log Type & CMP & Year Drill & 1981 & Twn Shp & 4 \\
\hline TwnShp Dir & $N$ & Rng & 12 & Rng Dir & W & $\mathrm{Sec}$ & 1 \\
\hline Sub Sec & $A B A D$ & FtNS & -551 & FtEW & -1328 & Lng & -98.6175565394 \\
\hline Lat & 40.3488352235 & Datum & NAD27 & Cnty & Webster & NRD & Little Blue \\
\hline Quad & Bladen & 100K Map & $\begin{array}{l}\text { Red } \\
\text { Cloud }\end{array}$ & $250 \mathrm{~K}$ Map & $\begin{array}{l}\text { Grand } \\
\text { Island }\end{array}$ & $\begin{array}{c}\text { FIdLog } \\
\text { Elev }\end{array}$ & 1955 \\
\hline ScrFId Elev & $\mathrm{u}$ & DEM & 1943.322 & Fin Elev & 1951 & ScrFin Elev & MAP \\
\hline DTW & $\begin{array}{l}75.8 \mathrm{ft} . \\
06 / 08 / 81\end{array}$ & TD & 200 & G Logs & True & E Logs & True \\
\hline D Logs & False & Hdr Notes & None & & & & \\
\hline & & & & & . & & \\
\hline & & & & & & & \\
\hline & & & & & & & \\
\hline & & & & & | & & 1 \\
\hline & & & & & ! & 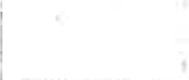 & \\
\hline
\end{tabular}

\section{Lithology}


LogID LithUnit Descrpt DepFm DepTo Notes 23-B-81 Road fill no detailed description recorded $\quad 0 \quad 5 \quad$ None 23-B-81 Silt $\quad$ slightly calcareous, very pale brown $\quad 5 \quad 10 \quad$ None 23-B-81 Silt

Silt
very pale brown $10 \quad 17 \quad$ None

23-B-81 Slightly clayey, slightly sandy,

moderately calcareous, pale brown, $\quad \begin{array}{llll}17 & 20 & \text { None }\end{array}$ sand is very fine to fine

\begin{tabular}{llllll}
$23-B-81$ & Silt & $\begin{array}{l}\text { slightly sandy, moderately calcareous, } \\
\text { light yellowish brown, sand is very fine }\end{array}$ & 20 & None \\
\hline 23-B-81 & Silt & $\begin{array}{l}\text { slightly sandy, moderately calcareous, } \\
\text { pale brown, sand is very fine to fine }\end{array}$ & 25 & 30 & None
\end{tabular}

\begin{tabular}{|c|c|c|c|c|c|}
\hline 23-B-81 & Silt & $\begin{array}{l}\text { slightly sandy, moderately calcareous, } \\
\text { light yellowish brown, sand is very fine }\end{array}$ & 30 & 31 & None \\
\hline $23-B-81$ & Silt & $\begin{array}{l}\text { slightly clayey, slightly calcareous, light } \\
\text { yellowish brown }\end{array}$ & 31 & 35 & None \\
\hline 23-B-81 & Silt & slightly clayey, light yellowish brown & 35 & 45 & None \\
\hline $23-B-81$ & Silt & light yellowish brown & 45 & 48 & None \\
\hline $23-B-81$ & Silt & $\begin{array}{l}\text { moderately sandy, light yellowish } \\
\text { brown, sand is very fine to fine }\end{array}$ & 48 & 49 & None \\
\hline 23-B-81 & Silt & light yellowish brown & 49 & 50 & None \\
\hline 23-B-81 & Silt & $\begin{array}{l}\text { slightly sandy, light yellowish brown, } \\
\text { sand is very fine, slightly calcareous } \\
\text { below } 51.0 \mathrm{ft} \text {, very pale brown below } \\
55.0 \mathrm{ft}\end{array}$ & 50 & 65.5 & None \\
\hline $23-B-81$ & Silt & light gray, very pale brown below $73.0 \mathrm{ft}$ & 65.5 & 81 & None \\
\hline $23-B-81$ & Silt & slightly clayey, light brownish gray & 81 & 89 & None \\
\hline
\end{tabular}

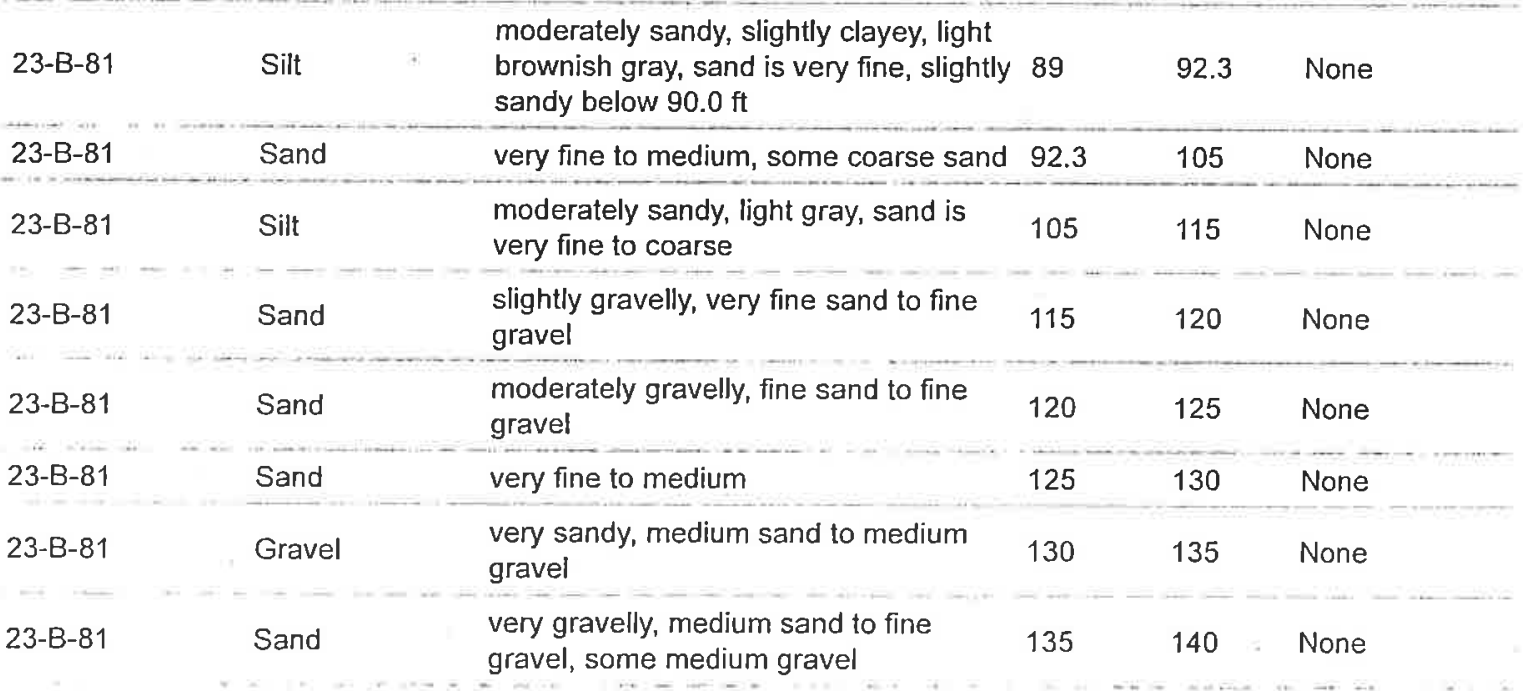




\begin{tabular}{|c|c|c|c|c|c|}
\hline LogID & LithUnit & Descrpt & DepFm & DepTo & Notes \\
\hline 23-B-81 & Gravel & $\begin{array}{l}\text { very sandy, medium sand to medium } \\
\text { gravel }\end{array}$ & 140 & 145 & None \\
\hline 23-B-81 & Sand & $\begin{array}{l}\text { moderately gravelly, fine sand to fine } \\
\text { gravel }\end{array}$ & 145 & 150 & None \\
\hline 23-B-81 & Sand & slightly gravelly, fine sand to fine gravel & 150 & 155 & None \\
\hline 23-B-81 & Sand & $\begin{array}{l}\text { fine to very coarse, some very fine } \\
\text { gravel }\end{array}$ & 155 & 160 & None \\
\hline $23-B-81$ & Sand & $\begin{array}{l}\text { slightly gravelly, fine sand to fine gravel, } \\
\text { some medium gravel }\end{array}$ & 160 & 178.3 & None \\
\hline 23-B-81 & Chalk & pale yellow, shaly & 178.3 & 180.3 & None \\
\hline 23-B-81 & Shale & $\begin{array}{l}\text { gray, very calcareous, dark gray below } \\
187.0 \mathrm{ft}\end{array}$ & 180.3 & 200 & None \\
\hline
\end{tabular}


LogID LithUnit Descrpt DepFm DepTo Notes

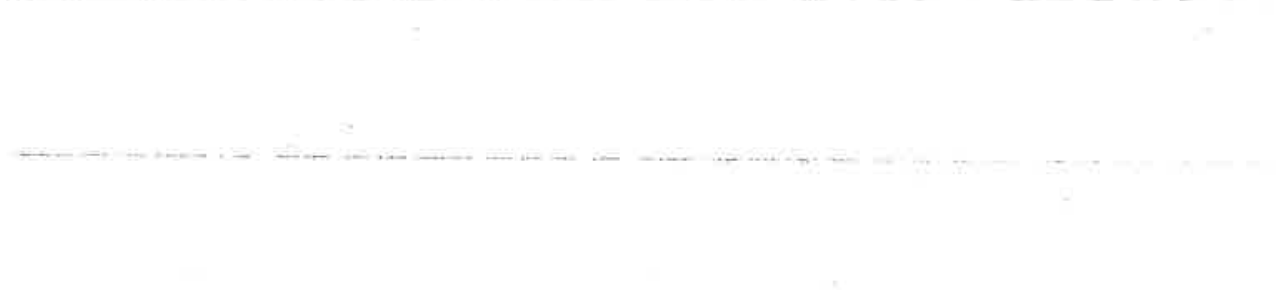




\section{STATE OF NEDKASKA DEPARTMENT OF WATER RESOURCES \\ IYET.L. REXISTHATION}

A ground wace well sill be registered when the following are completal and reicived together by

1. Well Registration Form (DW'R Folm $(02)$

2. Cerllficate of Well Driller (DIS'R Form 60u)

3. A \$21).00 fee (swajable to the Ditector of Walcr Resources) exorpt uhen registering:

a) a epplacement well. A replacement well shnll mean a well uhlich replibus a registered aliandoned well that was last opersted in the past five ycars and it within six hundied recl of said abandoned wellior,

b) well(s) permitted under the Mtunicipal and Rural Domestic Transfers I'ermit Act.

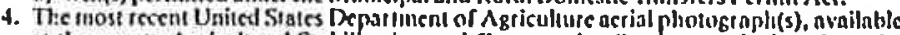

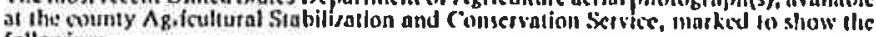
folloxing:

a) Tire location of the well to be registered.

b) Tne lowation of wells orned by you in the sante sertion. Lach well should tre labelat to stow the use of water and the registralion number. $A$ bandoned wells sliould be shown also.

c) If the well is for izzigation, the land to be irrigated shomld be shown by a trosshatch philtern and the number of neres intigated from tle well should tre indicated.

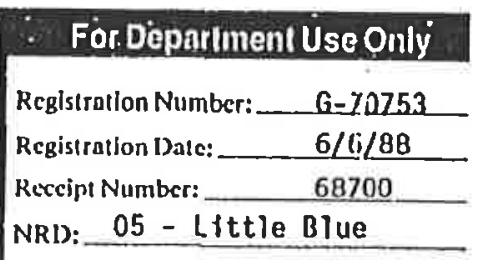

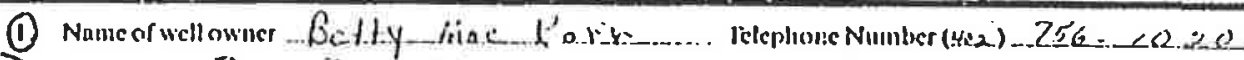

Address $5.0 .130 \times 18 \%$

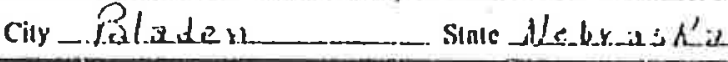

- 7ipcose 68928

2. Nane of well driller Pettorson He11 Dr1111ng Inc isclephone Number (403 462-5601

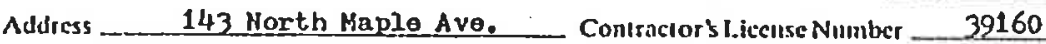

Cily _._ HastIngs _____ State___ Nebraska ______ Zip Coule ___ 68901

3. Grounil Walcr Control or Managenient Area Permit Number. NA L_title Blue NRD

4. Ciround walcr withdrawn from this well will be for Indicalcoune) XX_Irrigation _-Minnicipal use _Industrial use _... Oher

5. Replacenirm and abastdoned wellinfornation:

A. Is this well a replacenicut well? __ Yes $X X X$ No

B. Give the registration number or the nbandoned well:

C. The replacement well is

fov from lic itbandoned well.

D. The alsandoned well was Inst operated.

6. Hell and pump information:

A. L'umping ratc under normal conditions: 800 Balluns a minute.

B. Tolnl well depth: 182 - $\mathrm{cel}$.

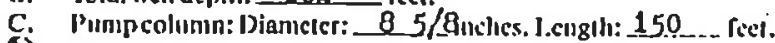

(D) Will chemicals or fertllizer be injo:ted inlo the distribution system? _ Yes + No

(a) The well was completed:_ 5. $53 . .8 \%$

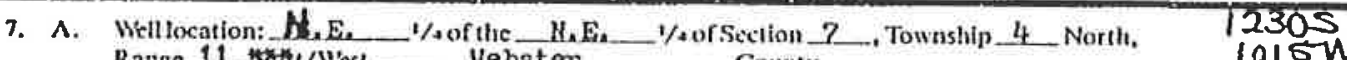
Range 11 Jlabster Count):

(1.) The well is .230 feet from the North/South section line and $122 / 5$ fect from the East/West sectlon liuc.

C. If for irrigation, the land to be irrigated is . $\angle \lambda O$ - acres in the following legal deseription: NaE, $7-4-11$ Kobster county

X Iam familiar with the information subnilted on this registratioh, and to he best of $y y$ knowlgdge $i$ is Iruc.

$x$ Dace ifmecene.3, 1988

Folmatd lo:

\section{Nell Owners Signature}

Simte nI Nibrate

lepastmenl of biver Hesaurces

301 Centeanlal Stall South

I:1). Hon 94A73

IIncoln Siebrasta 68509-4070

(+02) +71-2.4.1 


\section{STATE OF NERBASKA DIPARTMENT OF WATER RESOURCES 6. CERTIFICATE OF IVELI. DRILLFIR}

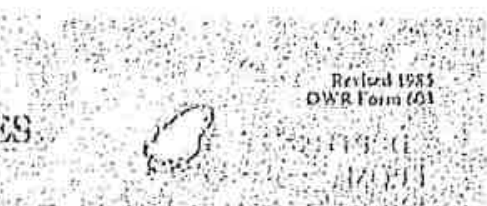

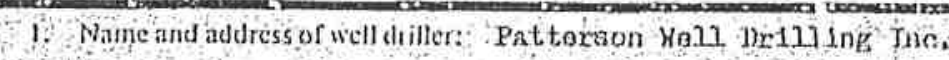
143 Nowth Haplos Ave.
(2) Name and suddress of well oyner: Bitty moe tarm $1302=157$ B/Bda, Nebr.
LipCoue Es\%2.8 Telcphone (sia) $256-120$.

3. Pernil Number $N A$ (II) applicable)

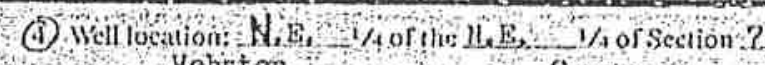

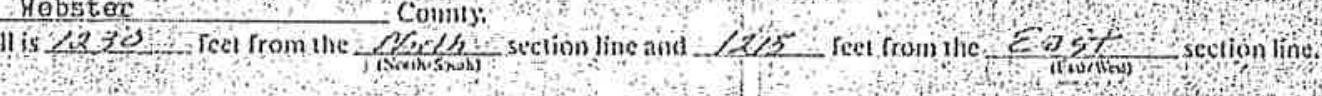

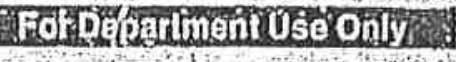

cegistration Wumber: $\quad G=70753$ i : Recistralton Dale:

$6 / 6 / 88 \%$ eccipt Number: $\frac{68700}{2} \mathrm{l}$ NRD: -05 - Little Blue

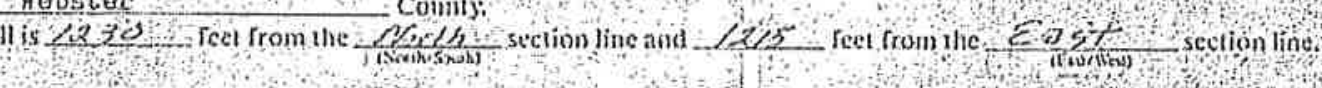
Townshí 1

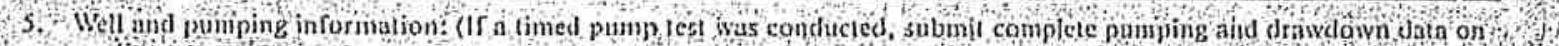
topirate shoct of paper.)

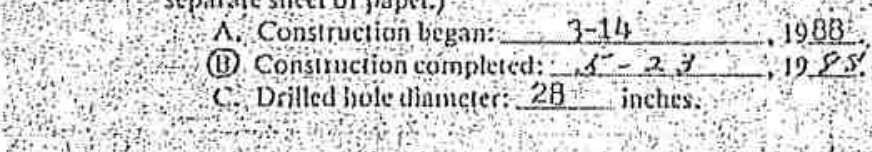

1). Sintic walcr level: 79 ret:

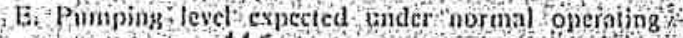

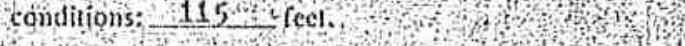
int

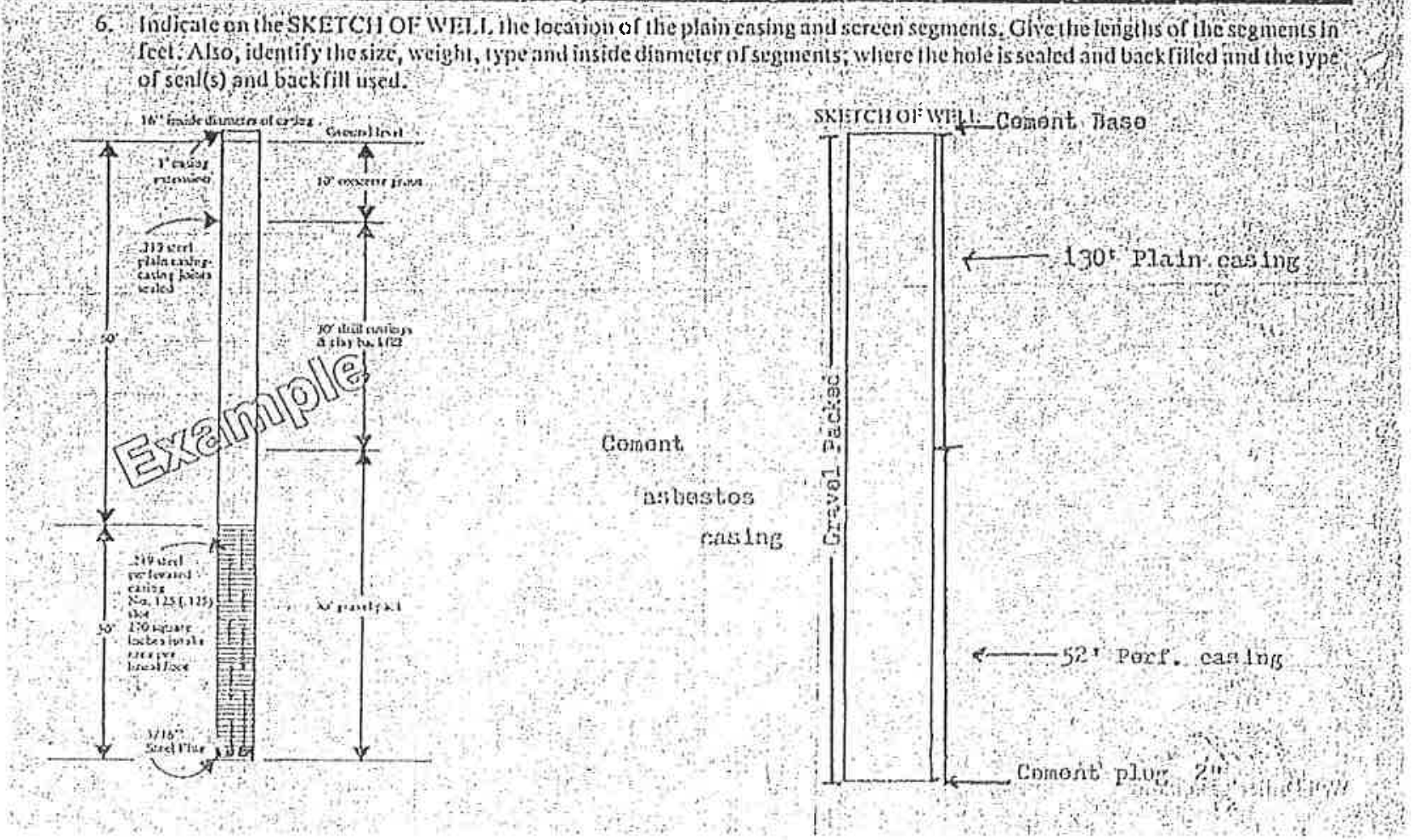




\section{IDRILLING;.OG}

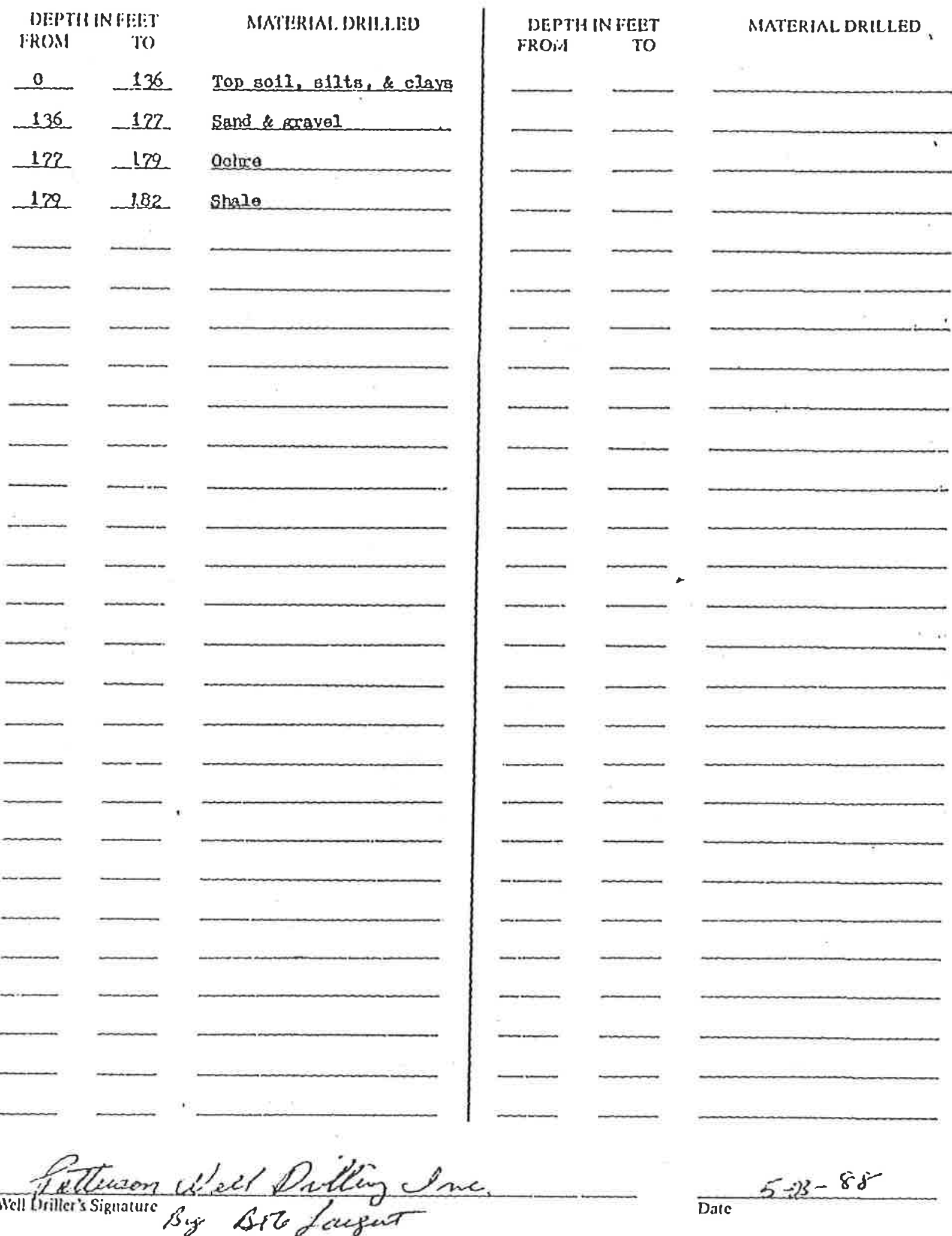


PWS 68-1

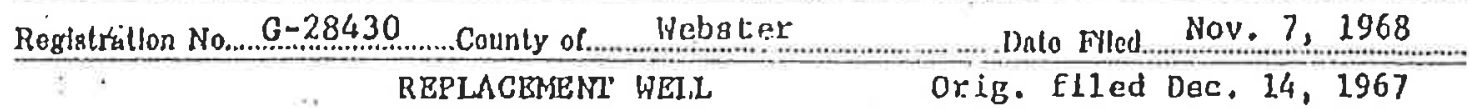

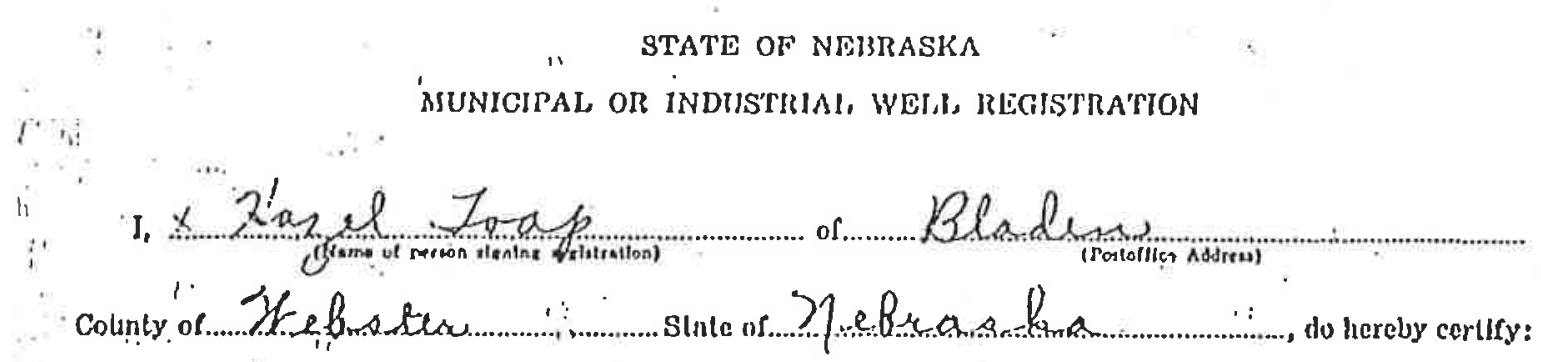

1st. That tho nnme of tho owner of tho munlelpn! (ov) Indusgtifil well reglatered herein fs...

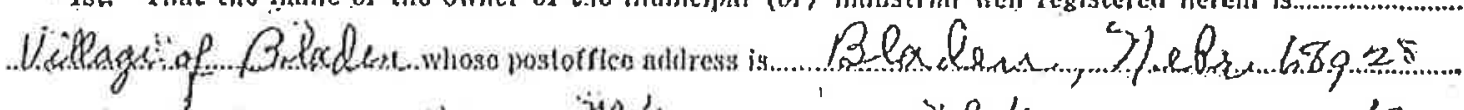

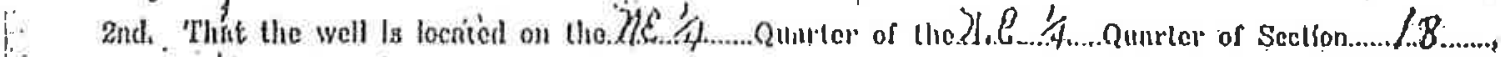

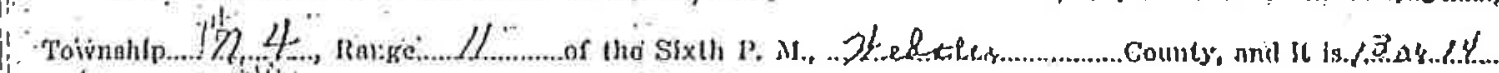
feot from tho

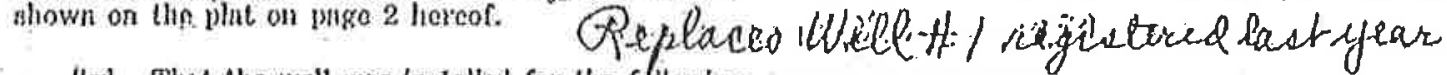

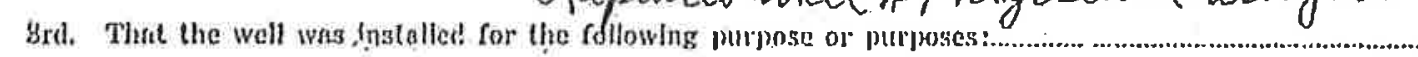

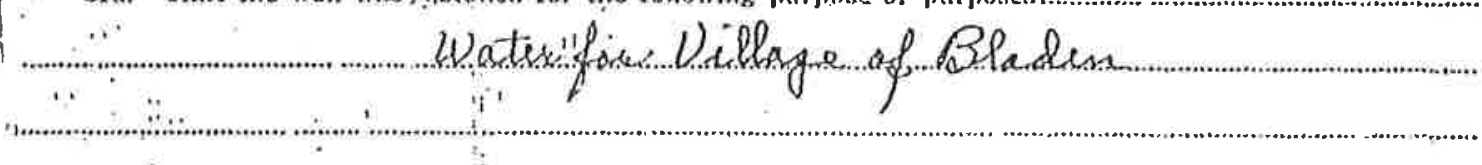

dth. Thal tho cannẹlly of snld well unter normnl oprernling conditions is......500...........gnllons per minule.

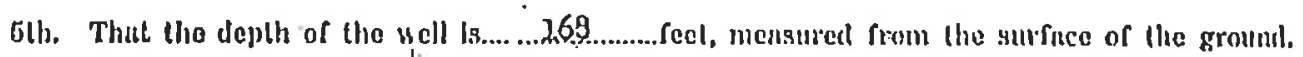

64!. What the fnslde diningeter of the caslng is...........18 ...... .inches.

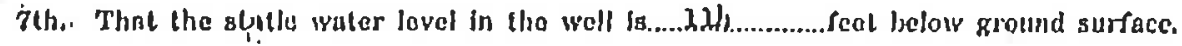

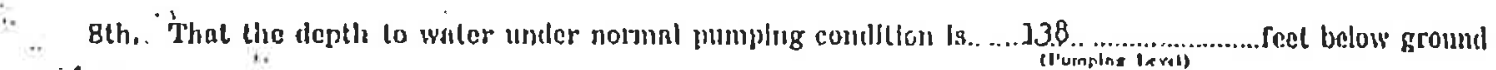
surfince.

$\therefore$.

gth. That the dlameter of the pump column is........ fi..5/8.inches. Thut the tlameter of the......? borl or: bouls Is.......10............Inclics.

10th. That the lype and size of inipeller lo fis follows:

ins

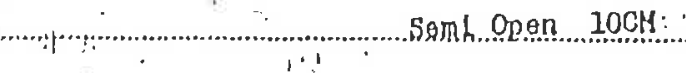

11th: That the woll was compluted on or ntrout tho. ... diny or ......tetopor. 10.60 

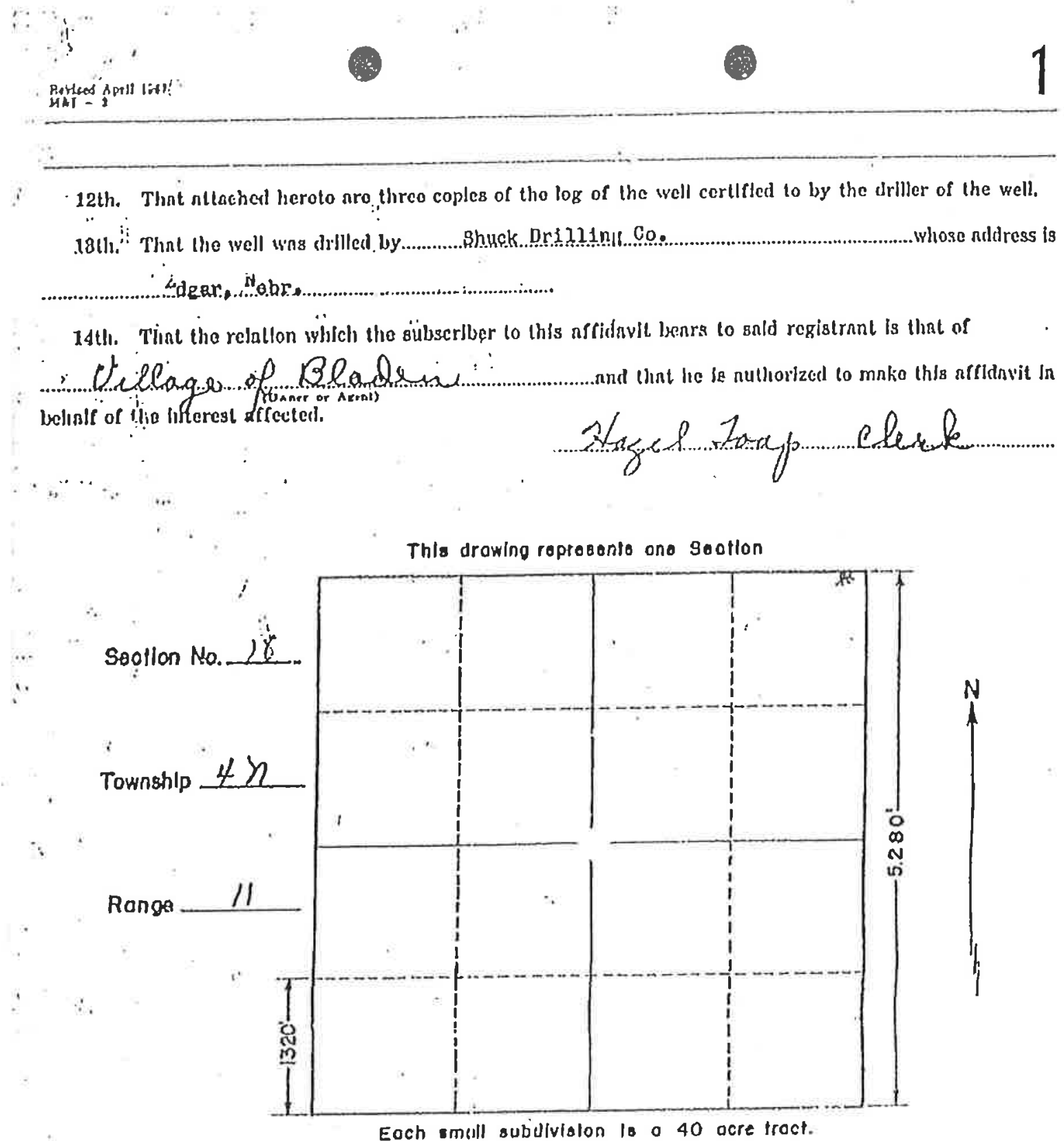

\section{Stata of Nebrrista}

Department of Whter Resutrees

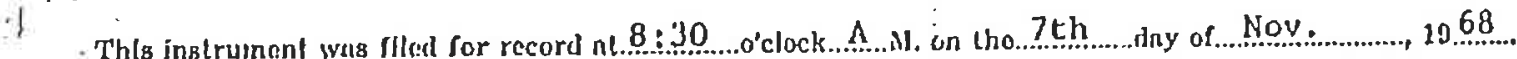
REPLACEMENT WELI, Ordg, r11Gd feg. 14, 1967. 


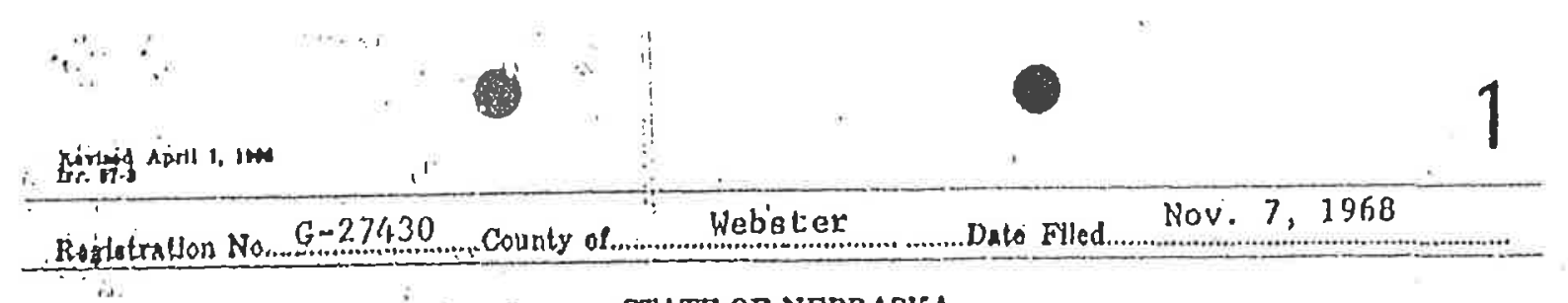

County of...clay.

! CERTIFICATE OF WFLL DRILLER

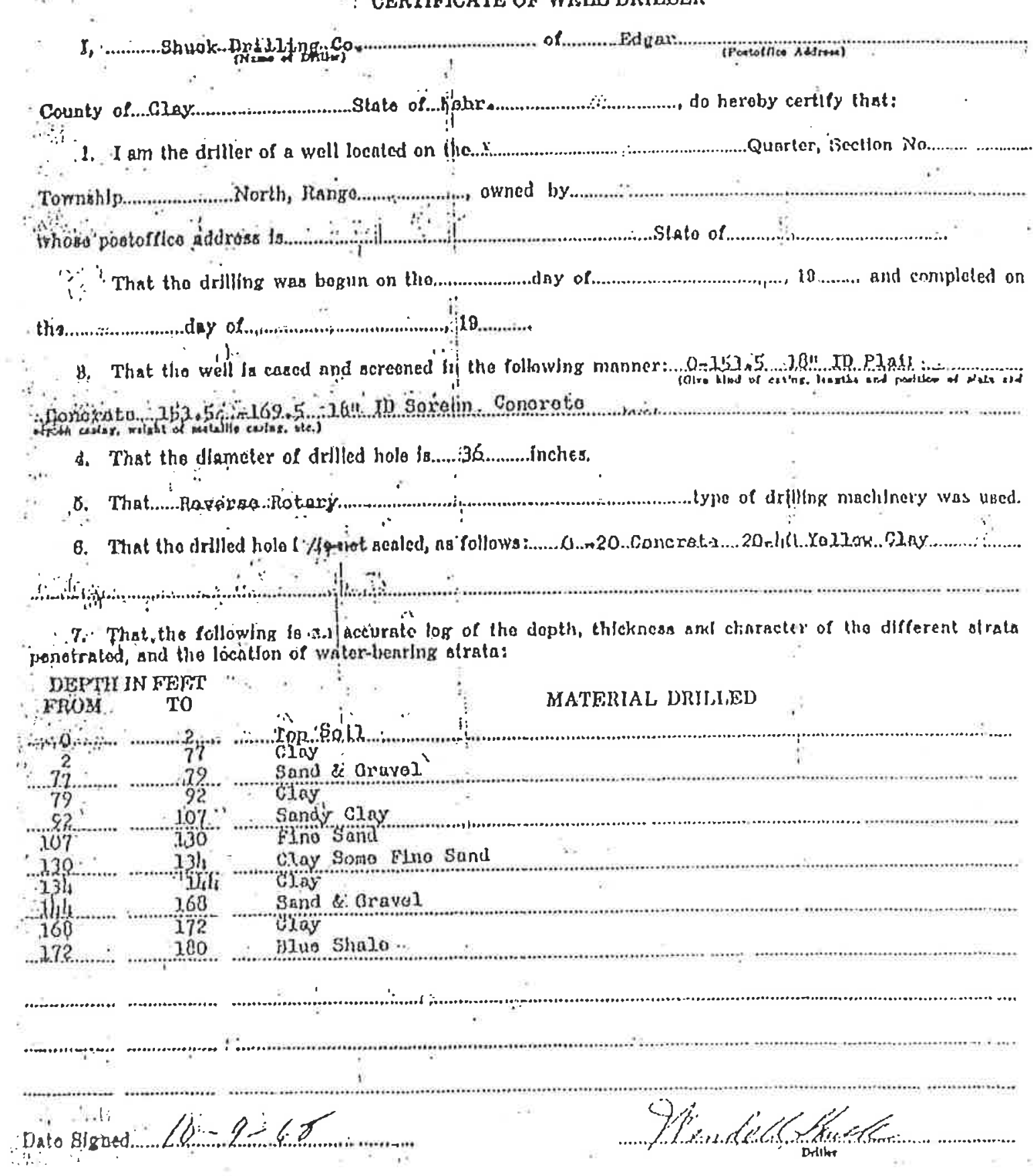




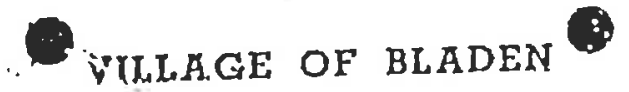

BI.ALTIN, NIIIRASKA

Tho Vizlago has a soound boll but alltho inforiation avallabldis as

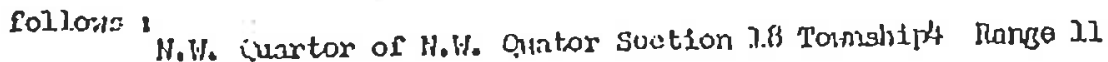

Doptli $: 168 \mathrm{ft}$.

$146 \mathrm{fl} 10$ inohos to tọf of azroon.

2l. coot 2 inili soroon

8p root mtor in moll.

8.) Soot to Hatori!

j.2 to 25 boriles i

1450 Ballons por n?muto.

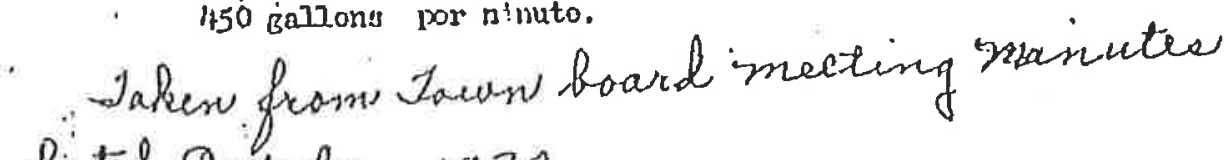
dited Q etaker 1930

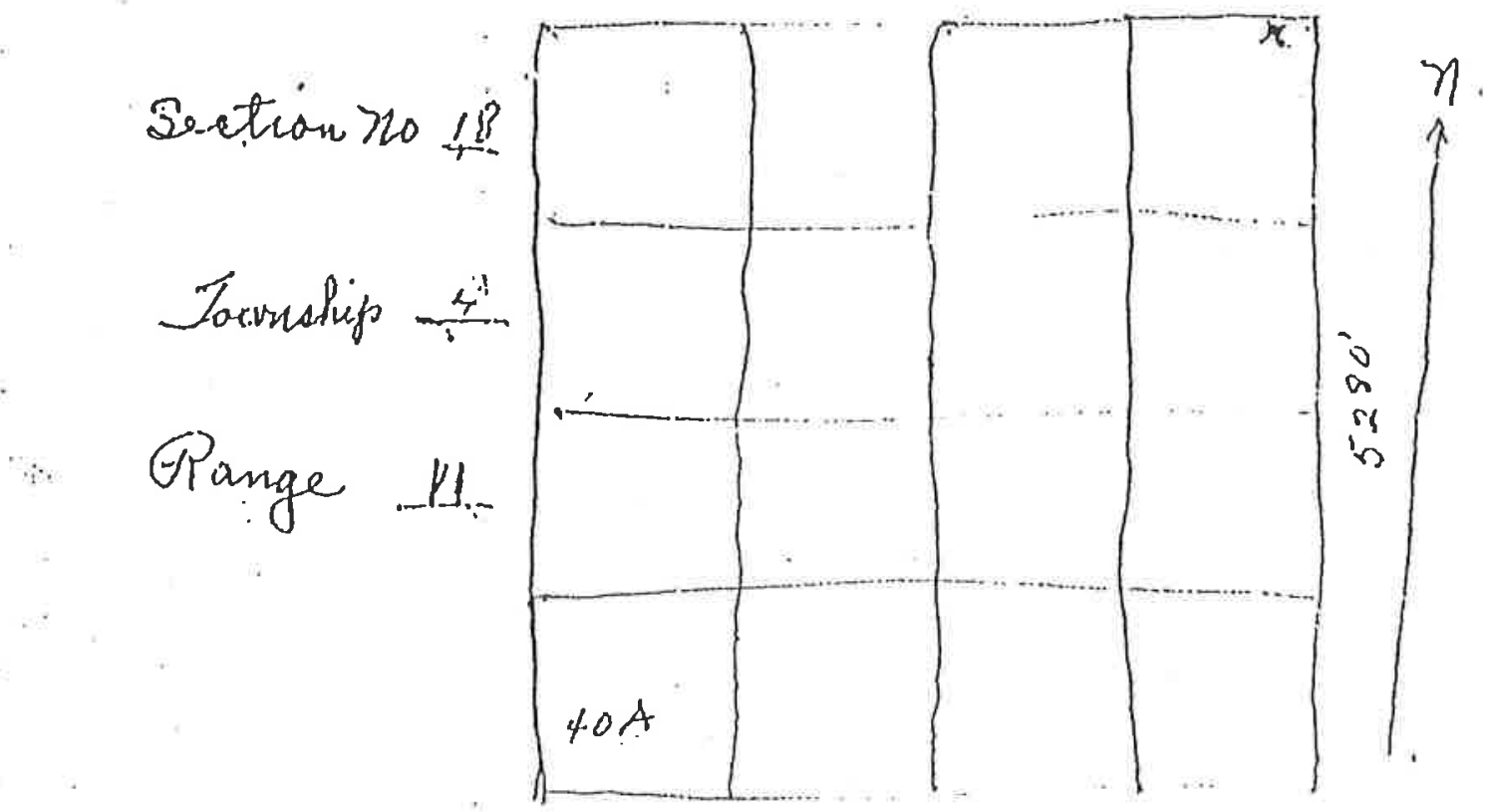




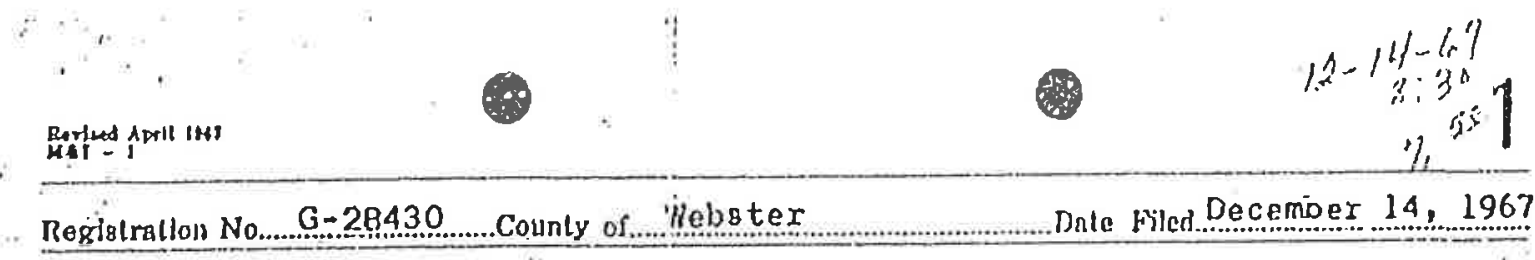

STITE OF NEBRASKA

MUNICIPAL, OR IHDUSTIRAL IVEL, REGISTRATION

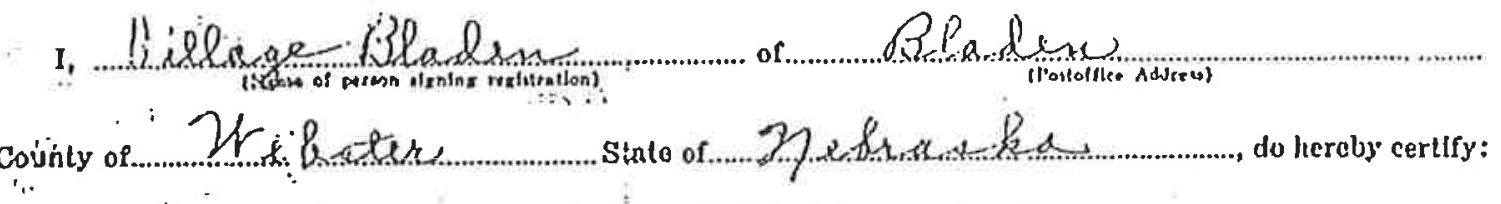

1si. That tho name of the ownor of tho hunicipal (or) industrinl well reglatcoel herein is

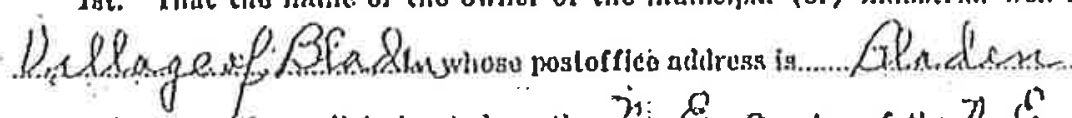

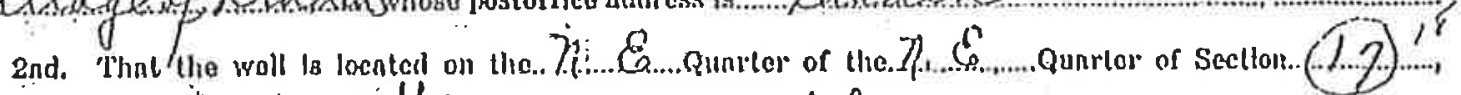

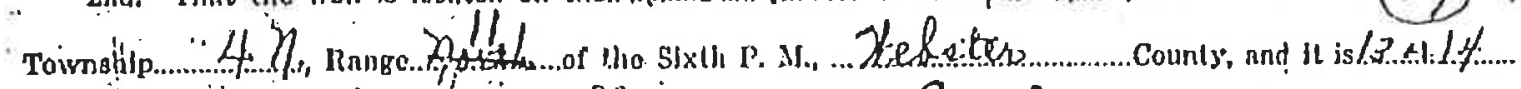

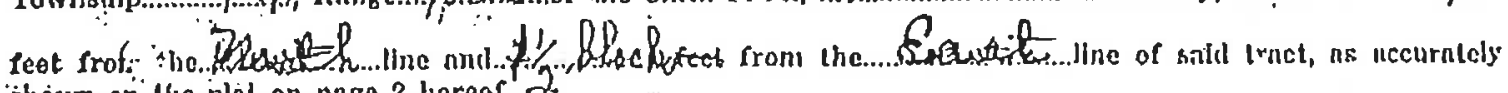
shown on the plal on pago 2 hereof. 2

3rd. 'That tho.wall was installed for tho following purpose or purposes:...

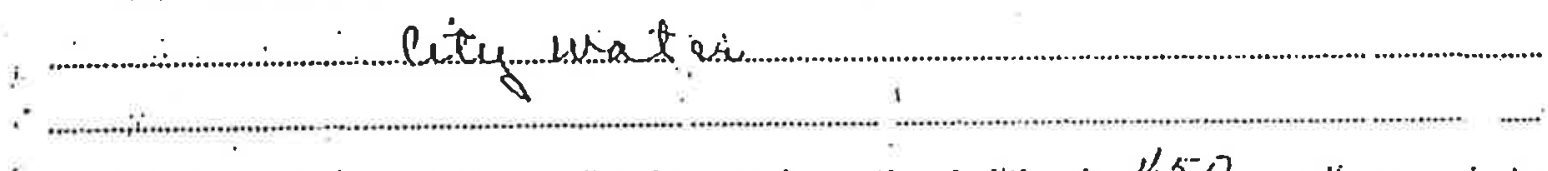

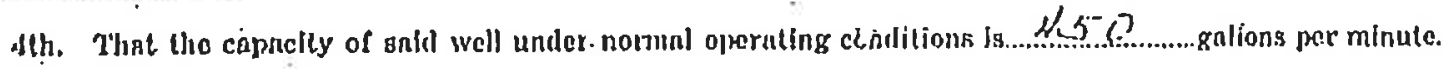

6th. That tho demtl of the well is...t.6...

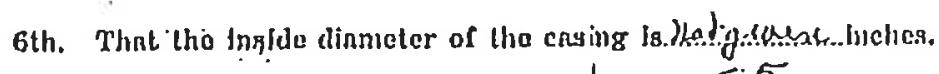

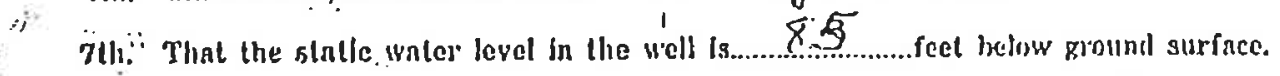

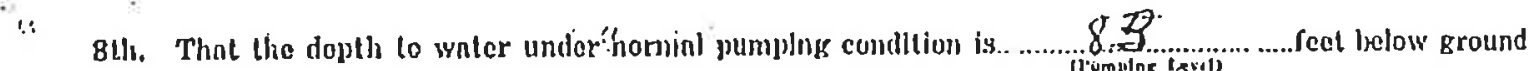
в.

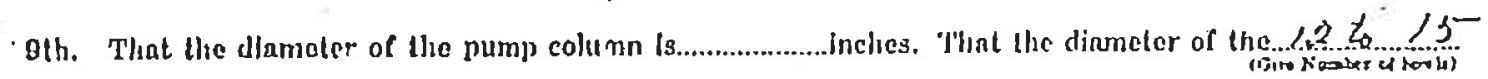

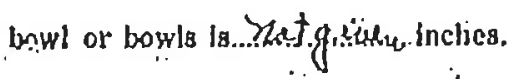

$\because$

16th. 'That ihe type and alze of Impeller II' na follows:

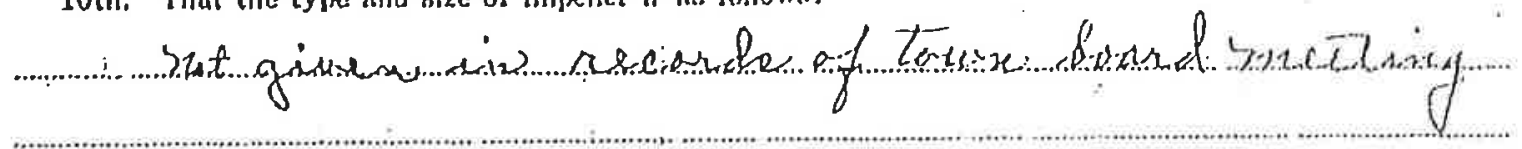

¿1. Ith. Thial tho woll wan comploted on or nlout the

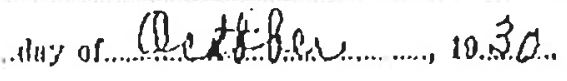




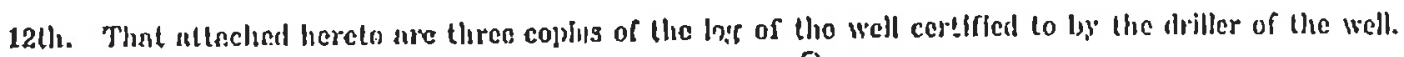

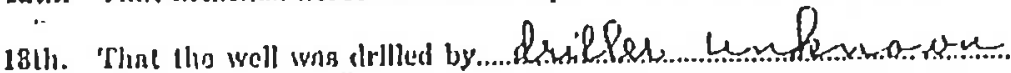
whost ndetress is

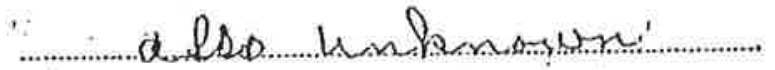

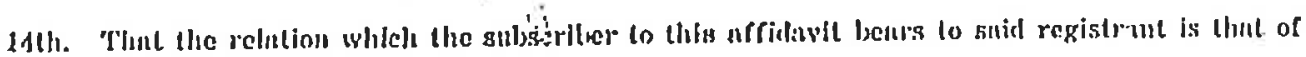

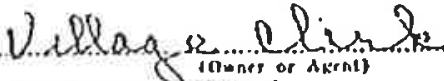

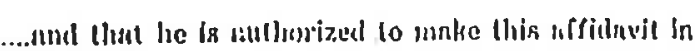
bolin!r of the intereat affecteil.

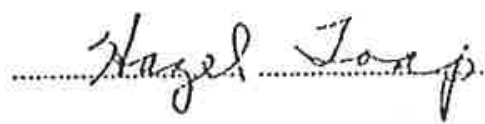

Thlo diawlng ropresanto one Seoflun

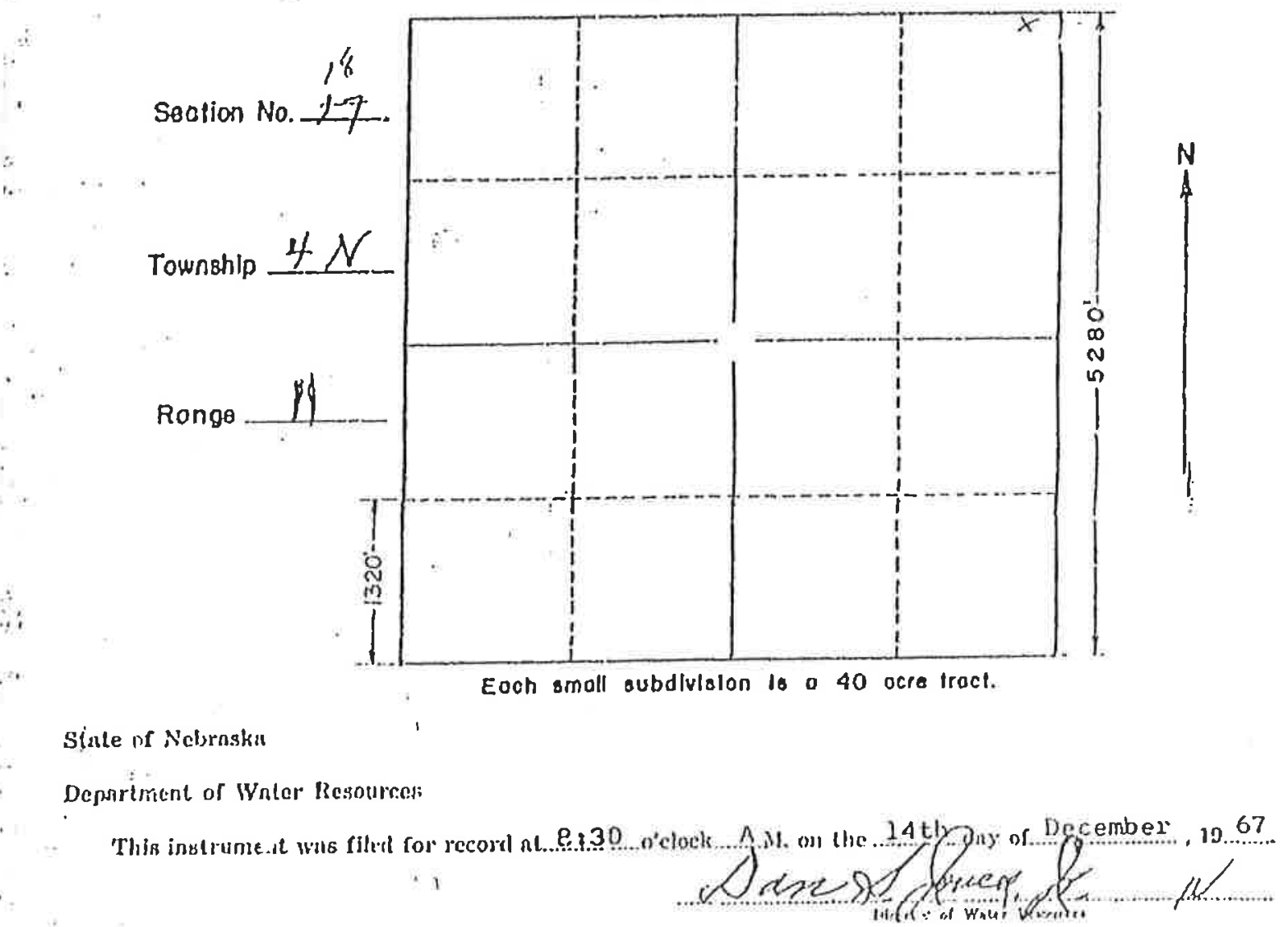

1.1 


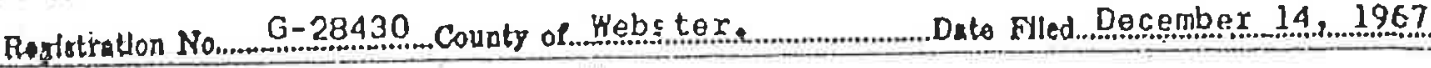

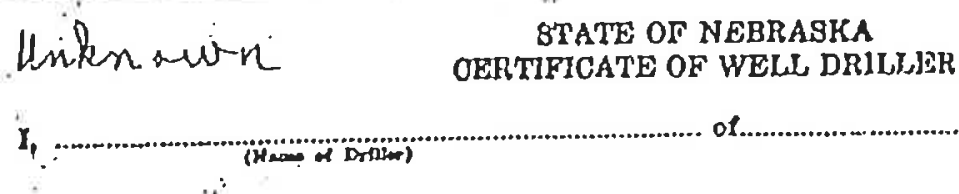

$x_{1}$

of.

1. I am tho driller of a well located on the.

4. That the dlameter of drilled hole is Jnches.

5. That
6. That thin difllod liole is/is sot sealed, as follows:

Quarler, Seclion No.

7. That the following is an acaurate $\log$ of the depth, thlekness and character of the dilferent atrata ponotratod, and the location of water-bearing alrata:

DEPTH IN FEET.

$\therefore$ FRPM

SIATERIAI, DRILLRD

$$
\text { . }
$$

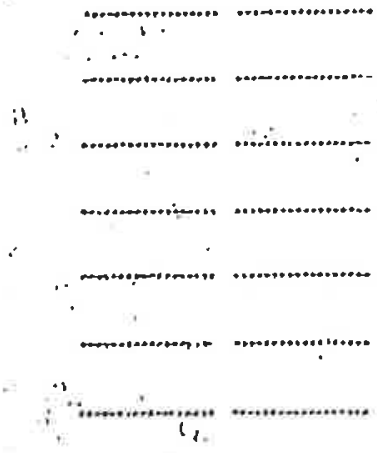$$
\text { Data Bigiad. }
$$ 


\section{DEPARTMENT OF WATER RESOURCES \\ WATER WELL HEGISTRATTON}

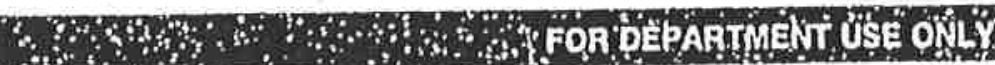

Registration Date 4-28-97 Sequence No. 104682 Registration No. G-91250

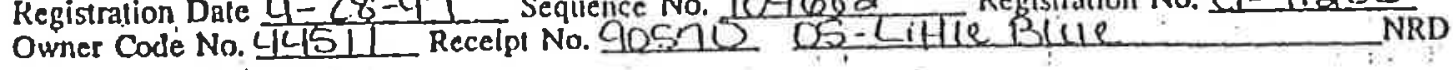

1. Wet Owark. David K. Berns: Telephone Nionber (4lex) $756-10 / 8$ Adtres nR\% Grox 40 City Bladenine State NE Zip Codo $-6089.28+9707$

$$
\therefore \cdot \cdot \cdot
$$

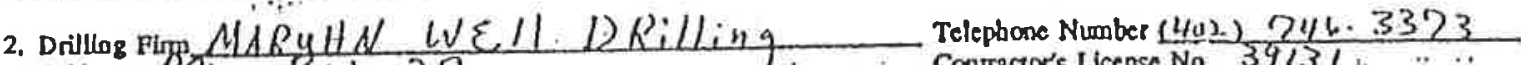

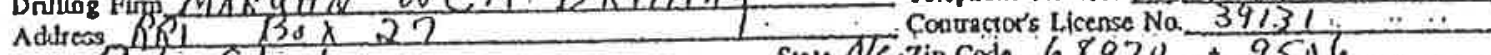

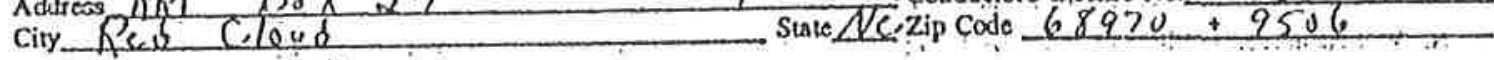

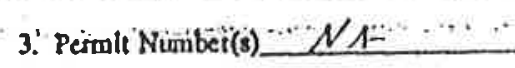

$\cdots+\infty+\infty$

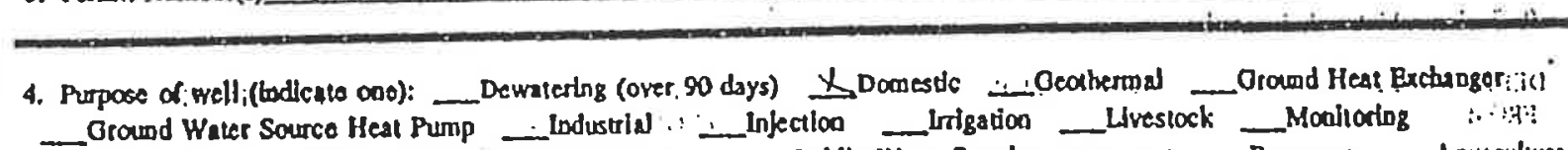

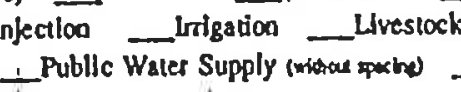
5. Replacement and abandoood well informution
A. Is this well a rëplaccment well?
C. Replecement well is
E. Original well pump column size: foel from abandooed well.
Yes IN No locbes.
B. Registration nuriber of ibandoned well:
D. Abandonod well last operated
p. Completion of original well abandonment on covery _._._quçulure
O. Location of water use of abandaned well:

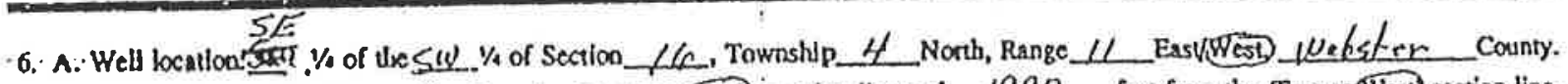

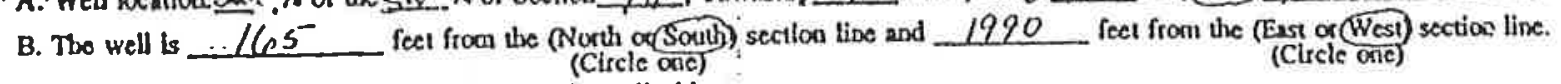

C. Streel address $\alpha$ block, lot and subdivision, if spollcable:

D. Locatlon of water use, if applicable (give legal descriptions):

E. If for irrigation, the land to be intigated is acres.

P. Woll refereone letter(s), if spplicabla:

acres.

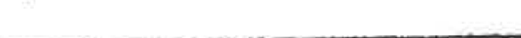

7. Purnp Information.
is pump Instalkd this time? $\mathrm{No}$

If yes, complete fiems $A$ through $\mathbb{\Gamma}$.
if no, complete fiems $A$ and $\mathbf{D}$ with estimated information for those wells in which pump will be installed.

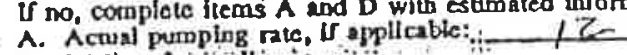

B. Pirúp columin diameler:

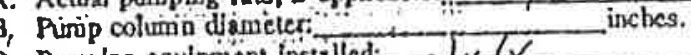

D. Rumplng equipment installed:

P. Pump instalied by: Controctor 0

Owoer 0

19.927.
Pump Insta

C. Length of pump column: Estimated 18

E. BrandType:

foet.

Pump installer $\square$ License No. 


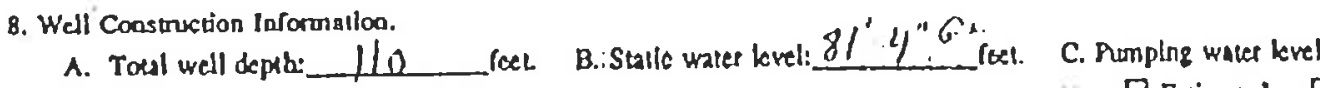
reet.

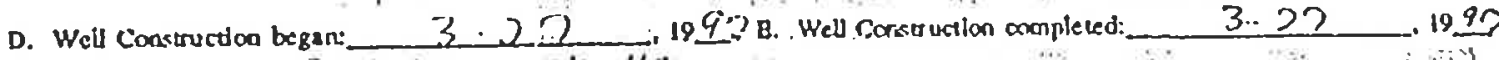

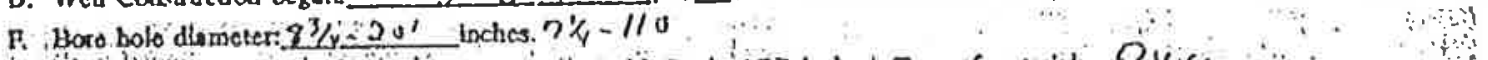

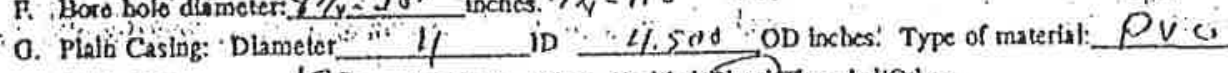

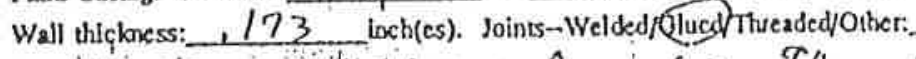

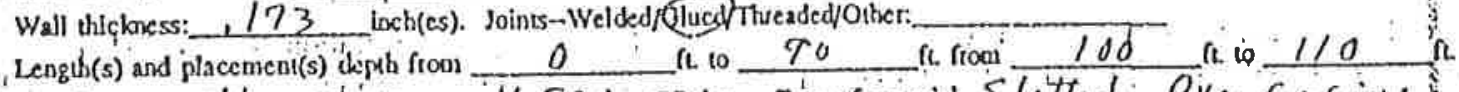

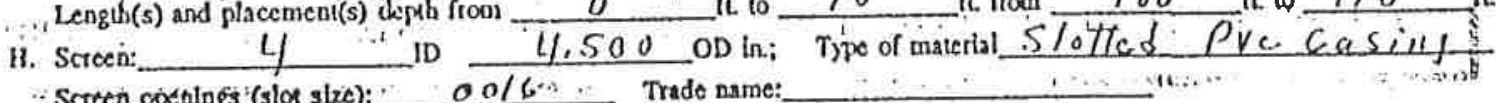
Screeta cpxtings (slot sizc): $\frac{00 / 6 \ldots}{10}$ Trade name:

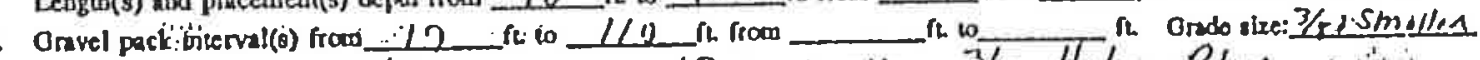

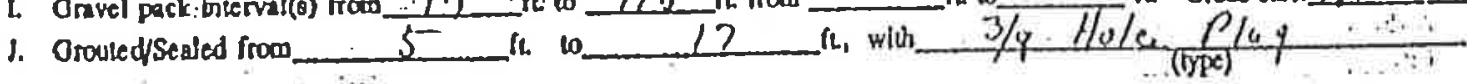
.. . ..... from
f.
IL, whith
(fip)
10.

K. brilstog method: . Roitany

L. Drilliog fluid: $X / 4 \psi_{4}, l_{4}$

M. Well development rechnlque (totol tme and method): ain $\mathrm{h}$ hails

N. Wu chiem If yes, whil will be used:

9. Coologic Malarials Logged $\cdots . . . .$.

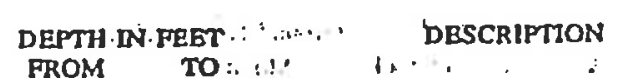

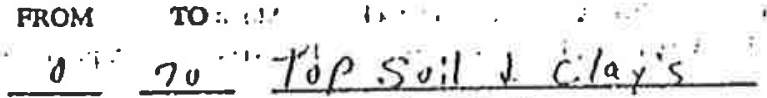

$\frac{20}{80}$

180

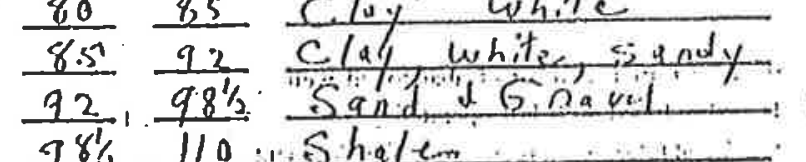

98\% $110.5 h \cdot$ Shem

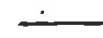

- $\cdots$

$\div$

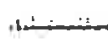

(1)

$$
\text { (n........ }
$$

$$
\text { Yes } 1 \text { No }
$$$$
\text { . }
$$

(......... 


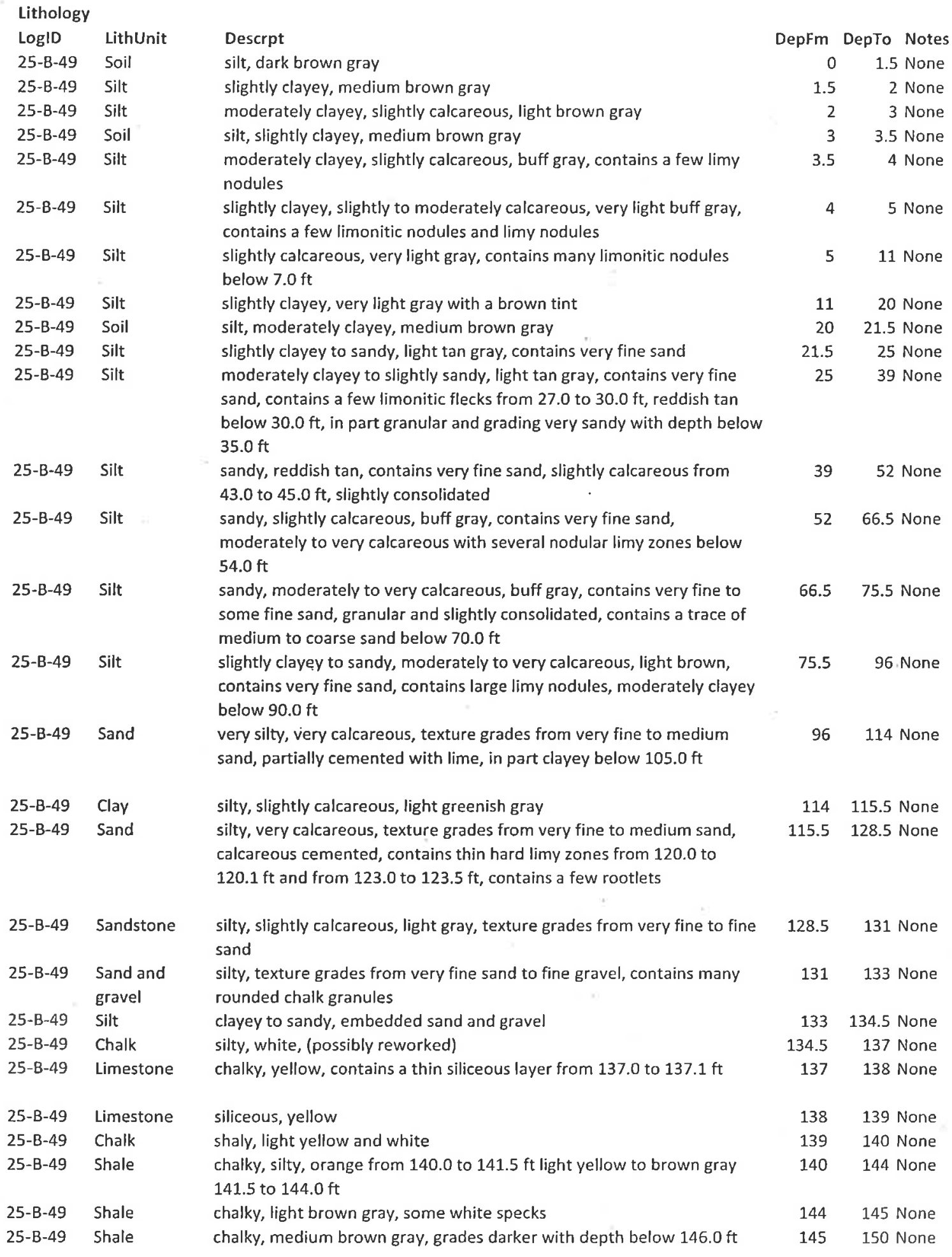




\begin{tabular}{|c|c|c|c|c|c|c|c|}
\hline \multicolumn{8}{|c|}{ Stratigraphy } \\
\hline LogID & Sys & Ser & Grp & Frm & Mem & DepFm & DepTo \\
\hline $25-B-49$ & Quaternary & & & & & 0 & 96 \\
\hline $25-B-49$ & Tertiary & Miocene & Ogallala & & & 96 & 134.5 \\
\hline $25-B-49$ & Cretaceous & Upper Cretaceous & Colorado & Niobrara & & 134.5 & 150 \\
\hline
\end{tabular}




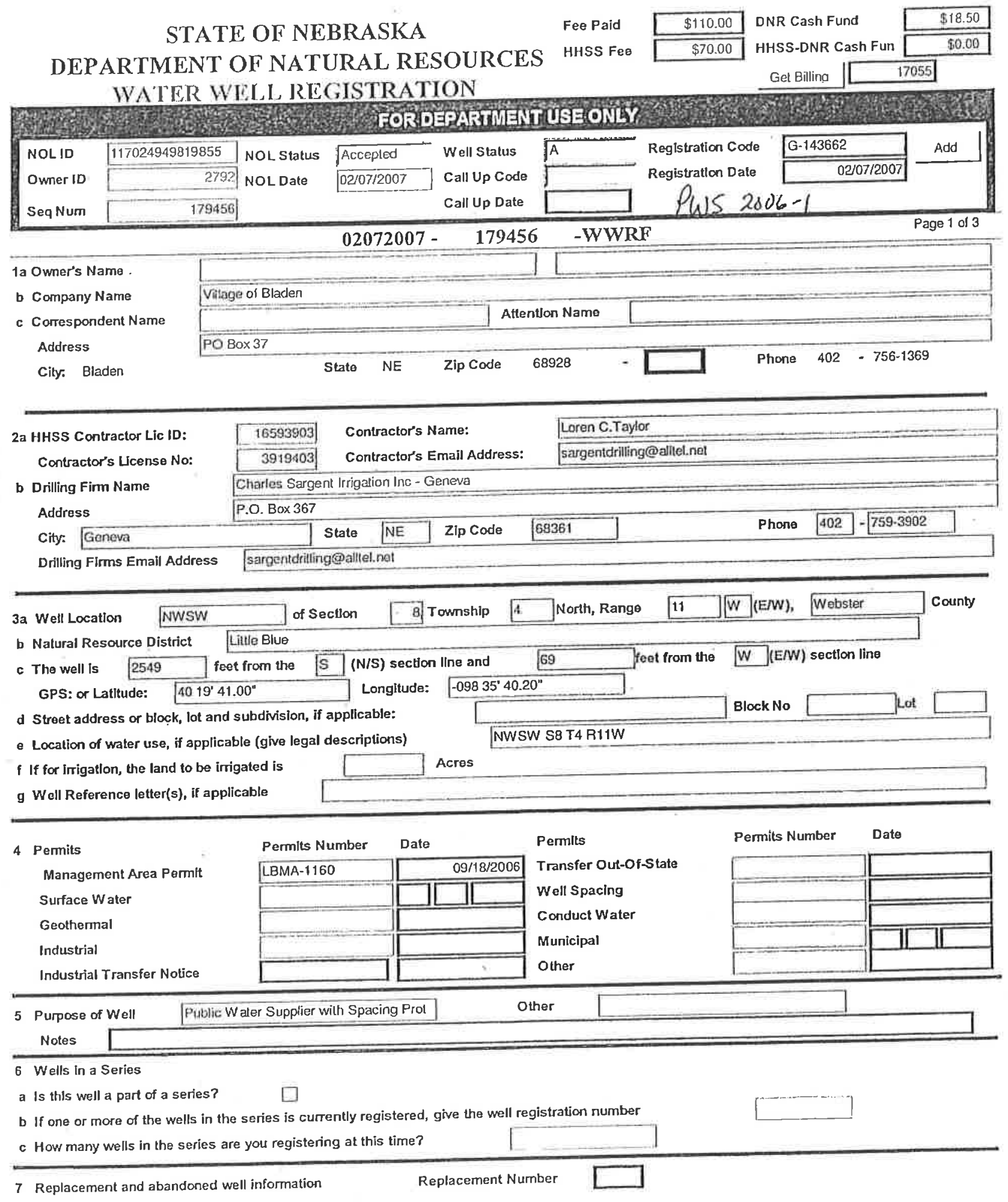




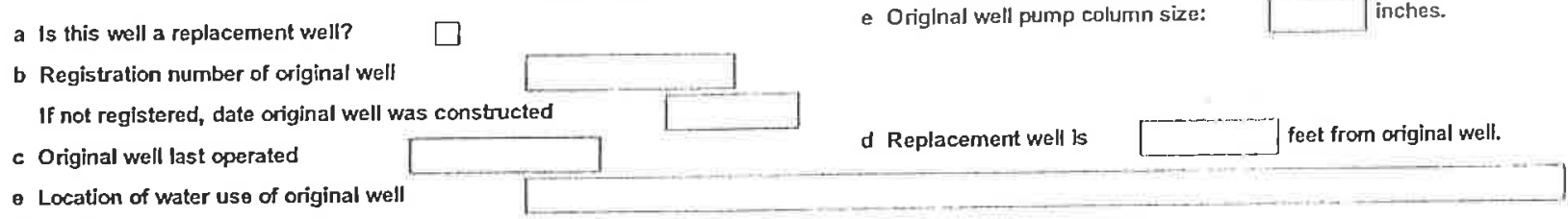

- Location of water use of original well

Please Select One:

f. $\square$

Use: $\square$

if nonconsumptive, State use:

8 Pump Information

a Is pump installed at this time? $\square$

Is pump installed by well owner in section 12

Else installed by pump installer.

b HHSS Installer's License ID.

Pump Installer's License No.

Pump Installer's Email Address

Pump Installer's Firm Name

Pump Installer's Flrm Address

City: Geneva

Pump Installer's Firm Email Address

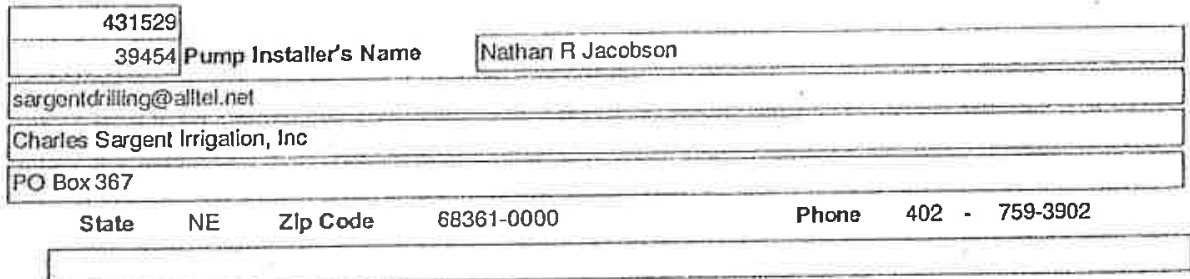

c Purnplng Rale 450 gallons per minute measured or estimated

d Drop pipe diameter $\quad 6$ inches $\quad$ e Length of drop pipe 140.

f Pumping equipment Installed $[01,11,2007$

g Pump Brand SPC

h This well will be used to pump lass than $50 \mathrm{gpm}$

9 Well Construction Informatlon

a Total well depth 181 . feet.

c Pumping Water Lovel 130.

e Well construction completed: $\quad 09] 27$ 2006

g Casing and Screen Jolnts Welded Other

b Static Water Level 106 .

d Well constructlon began: $\quad 09$, 72,2006

f Bore hole diameter in Inches. Top 32.

10 Well Constructlon (Casing and Screen)

\begin{tabular}{|c|c|c|c|c|c|c|c|c|c|}
\hline Fr Depth & To Depth & Case Scrn & In Diam & Out Diam & Thickness & Scrn Slot Size & Material & Trade name & NOLID \\
\hline 0 & 152 & casing & 15.25 & $16 \vdots$ & .375 & & Steel & Livingston & 117024949819 \\
\hline 152 & 169 & screen & 15.25: & $16:$ & .375 & 090 & Steel & Johnson Ag & 117024949819 \\
\hline 169 & 181 & casing & 15.25 & 16 & .375 & & Steel & Sump & 117024949819 \\
\hline
\end{tabular}

11 Well Construction (Grout and Gravel)

\begin{tabular}{|c|c|c|l|l|}
\hline NOL ID & From Depth & To Depth & GroutGravel & \\
\hline 117024949819855 & 0 & 17 grout & Concrete & Material \\
117024949819855 & 17 & 127 grout & Bentonite \\
117024949819855 & 127 & 175 gravel & Gravel \\
117024949819855 & 175 & 181 grout & Coated Bentonite \\
\hline
\end{tabular}


02072007 - 179456 -WWRF Page 3 ol 3 12 Geolog Material Logged

\begin{tabular}{|c|c|c|c|}
\hline NOL_ID & From Depth] & Description & \\
\hline 117024949819855 & 0 & 20.Topsoil and clay & \\
\hline 117024949819855 & 20 & 88 Clay & \\
\hline 117024949819855 & 88 & 120 Medium to coarse sand with clay layers & \\
\hline $117024949819855:$ & 120: & 137 Clay with medium to coarse sand & \\
\hline $117024949819855=$ & 137 & 140 Medium to coarse sand with trace of fine gravel & \\
\hline 117024949819855 & 140 & 145:Medium to coarse sand & \\
\hline 117024949819855 & 145 & $168:$ Coarse sand with fine to medium gravel & . \\
\hline 117024949819855 & 168: & 181 Ocher and sthale & \\
\hline
\end{tabular}


PWS $68-1$

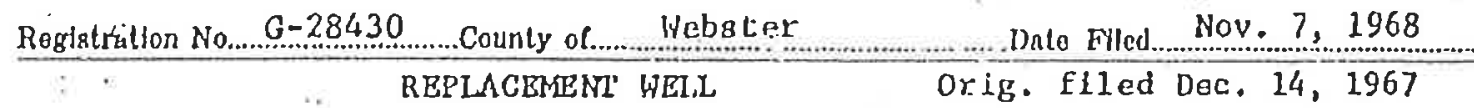

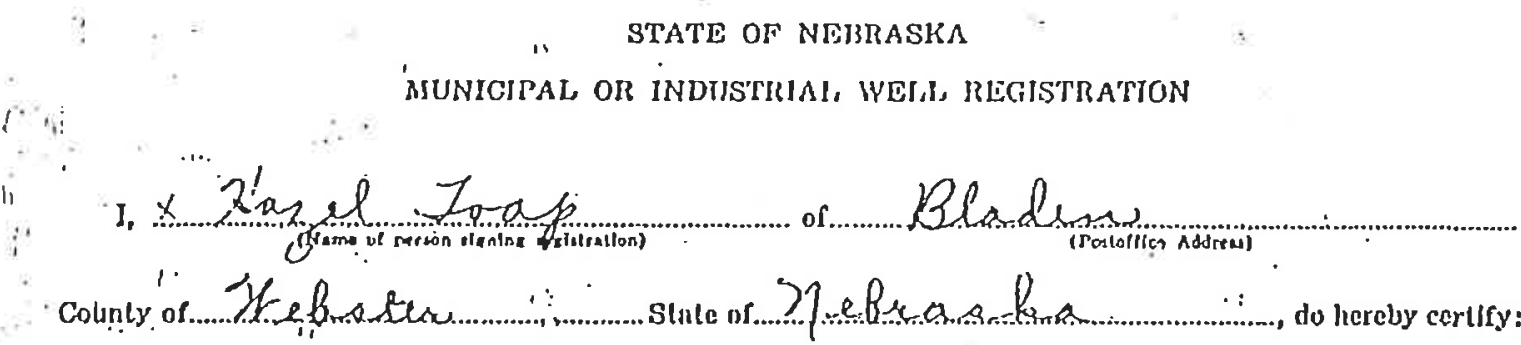

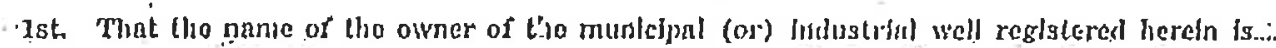

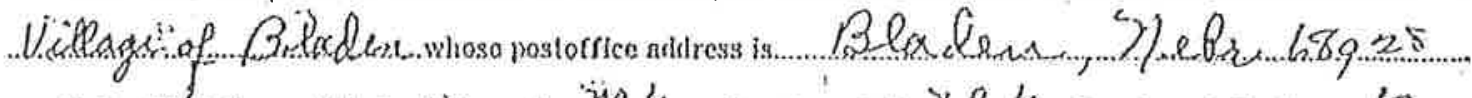

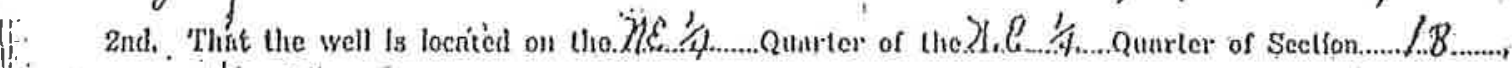

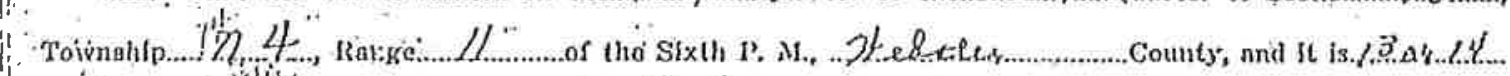

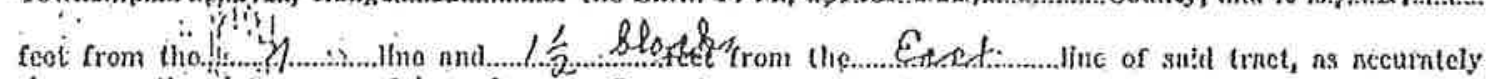

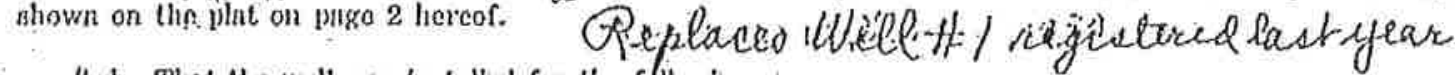

srd. Throt the well wos instalict for the following purjose or purposes:...

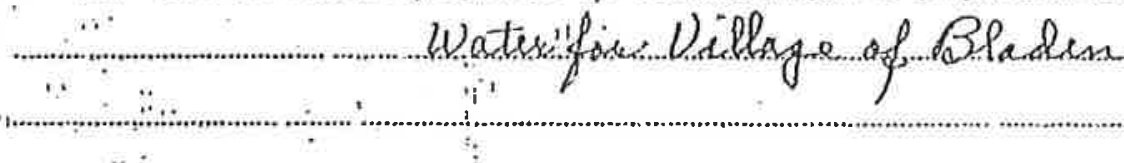

Alli. That the cajugelty of sali well under normal operaling conditions is.......500............gallons prer minule.

6th. Thut the depth of the well is..........69........feet, mensuted from the sutrfuce of the grount.

6th. What the inglde dinmeler of the casing is........................ Inches.

rth. That the slyelu water lovel in tho woll is.....

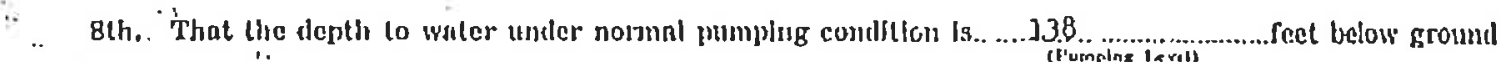
slitifnce.

$\therefore$

oth. That the dfameice of tho pump column is...........5/8.inclies. That the tlameler of the.....?. bowl or bowls is......... I0............ Inclice.

101h. That the type nnd size of impeller is sts follows:

.

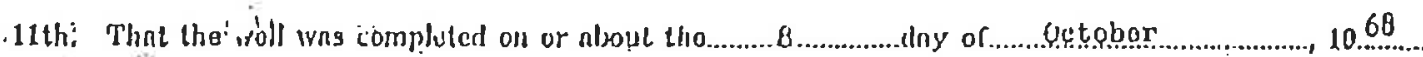


$\therefore$

's ...

Pritros Aprll lint:

8

12th. Thit sltachel heroto sro threo coples of tho log of the well cerllffed to by the drllicr of the well.

.18th.; That the well sins drilled. by.

Shuck. Drit]1!nit.......

whose nddress is i.....dear. . Nobr.

14th. Tinat the relallon whilch the suluscriber to this affidavil lenrs to gald registrant is that of

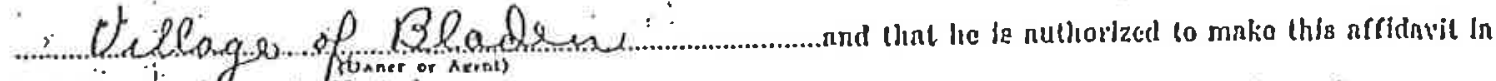
belinlf of tilio tuterest affecteri.

. , $\cdots$
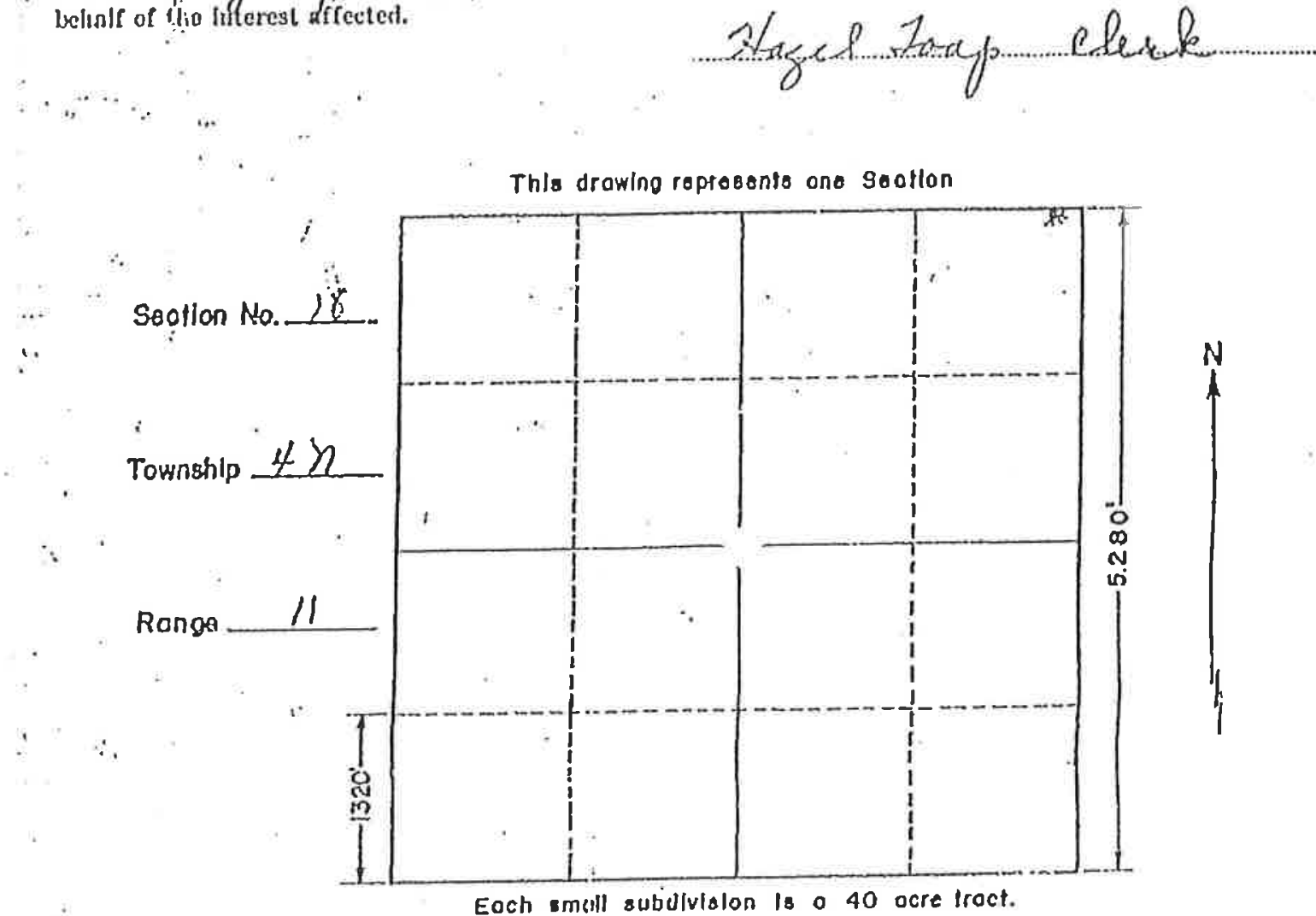

\section{Slatä of Nebroskn}

Lepartmenl of Water llesources

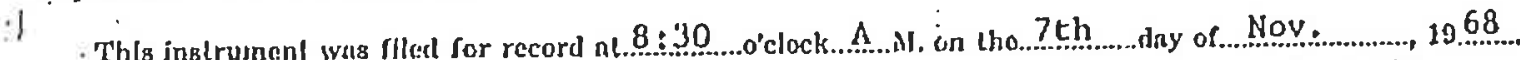

REPLACEMEN WEIL OrJg, f1led fec. 14, 1967

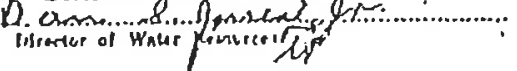




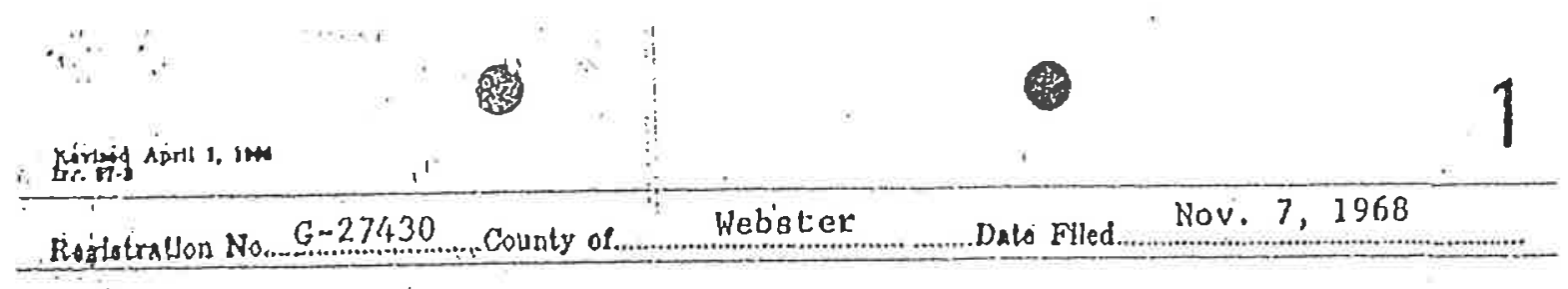

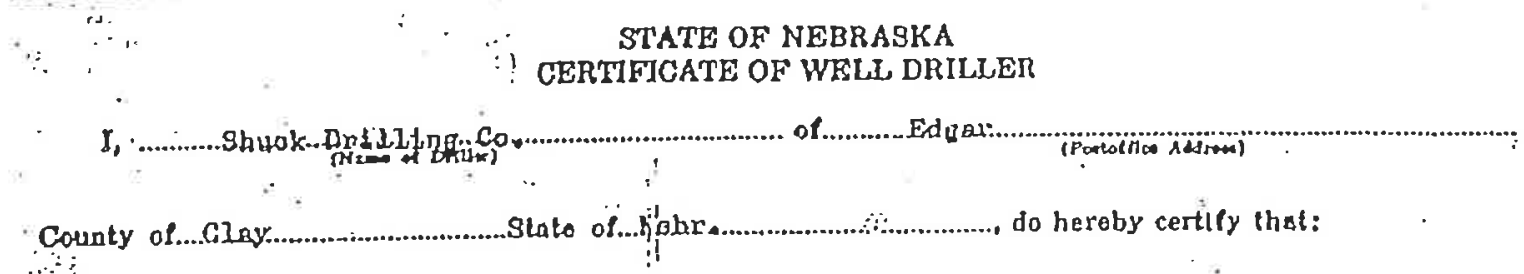

1. I am the drlller of a well locnted on ịc...................................................Qunter, isectlon

Qunror, iscellon so.

Tornishlp.......................North, Nango..................., awned by

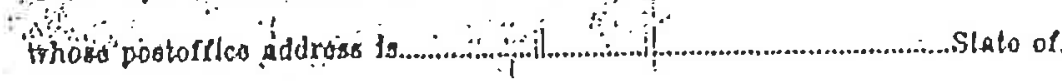

$\because \because$ ? That the drilling was bogun on the, dny of. $10 \ldots . . . .$. and compleled on

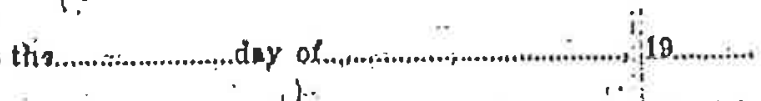

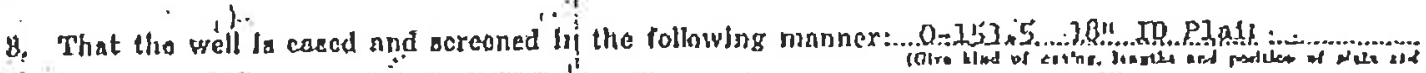

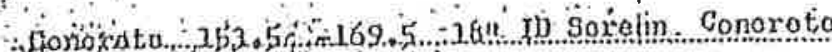

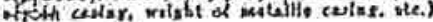

4. That the diameler of drilled holo ds......j6........inches.

$\cdots$...

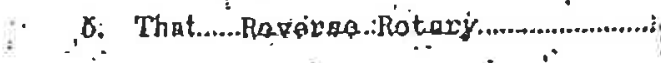

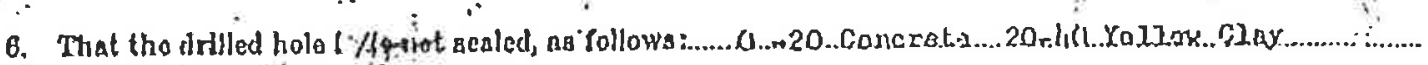

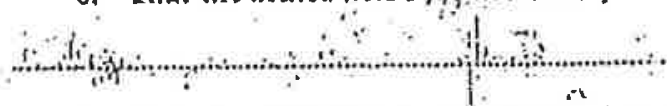

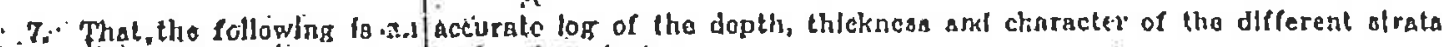
ponotratod, and the locition of water-benting strata:

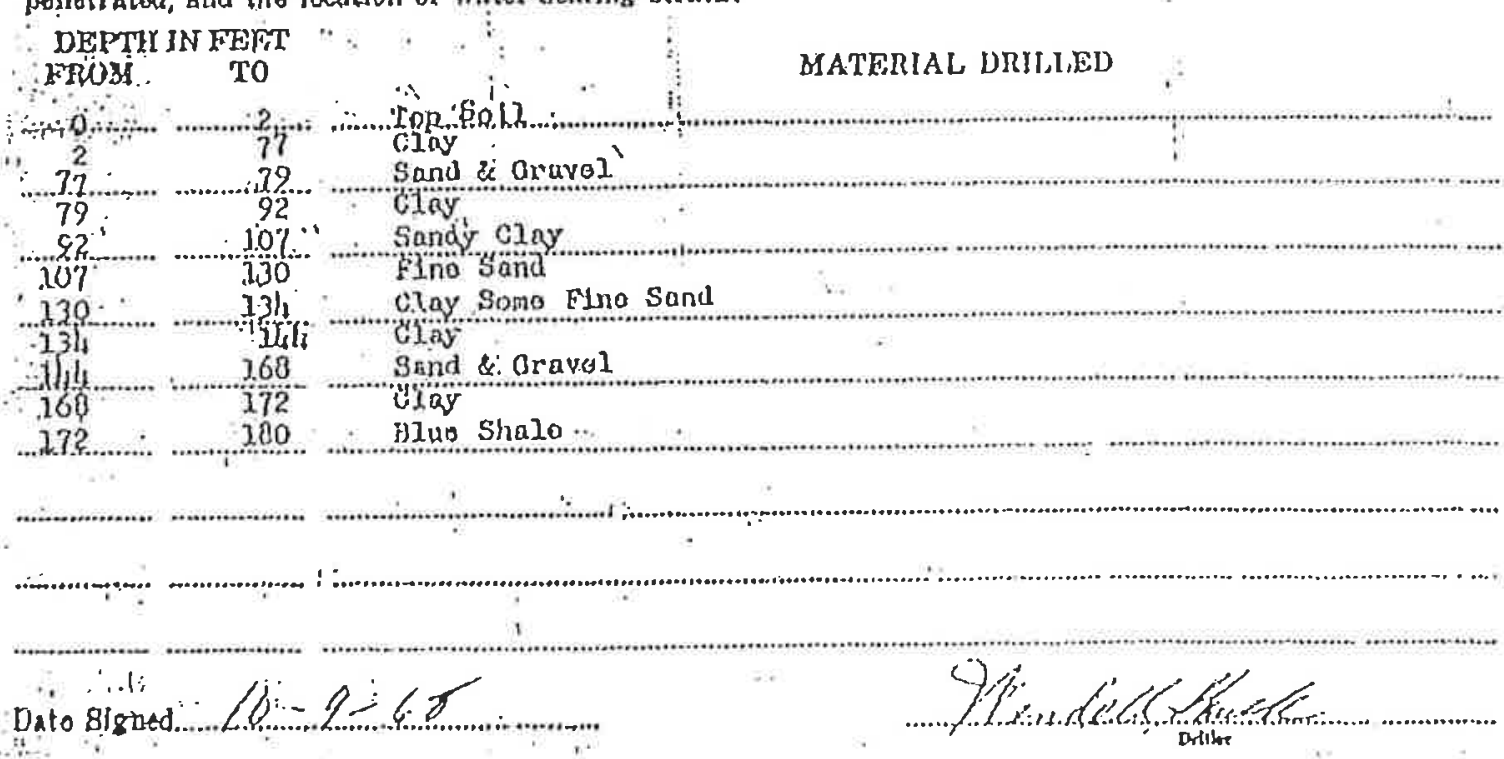


AI.ALIN, NBIHASSKA

Tho villago has a socind r.oll but alltio inforiation availabldis as

follone 1

N.W. iuartor of H.H. Ọator suction 7.86 Tomishiplt Range 11

Doptls : $168 \mathrm{ct}$.

146 It 10 inoliog to tọfi of arroon.

2i. foot 2 inili soroon

8 p root ritor in woll.

8,) Soot to wateri!

j.2 to 15 boriled?

150் вalzons por a?nuto.

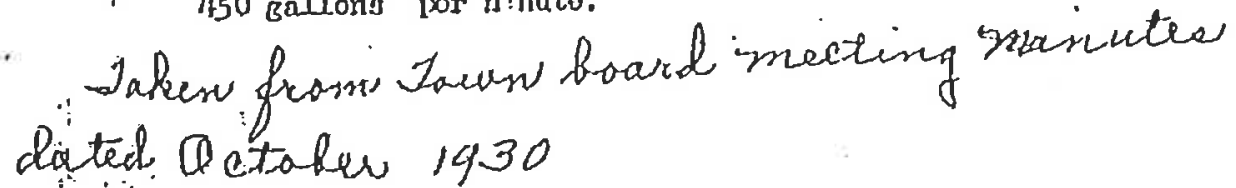

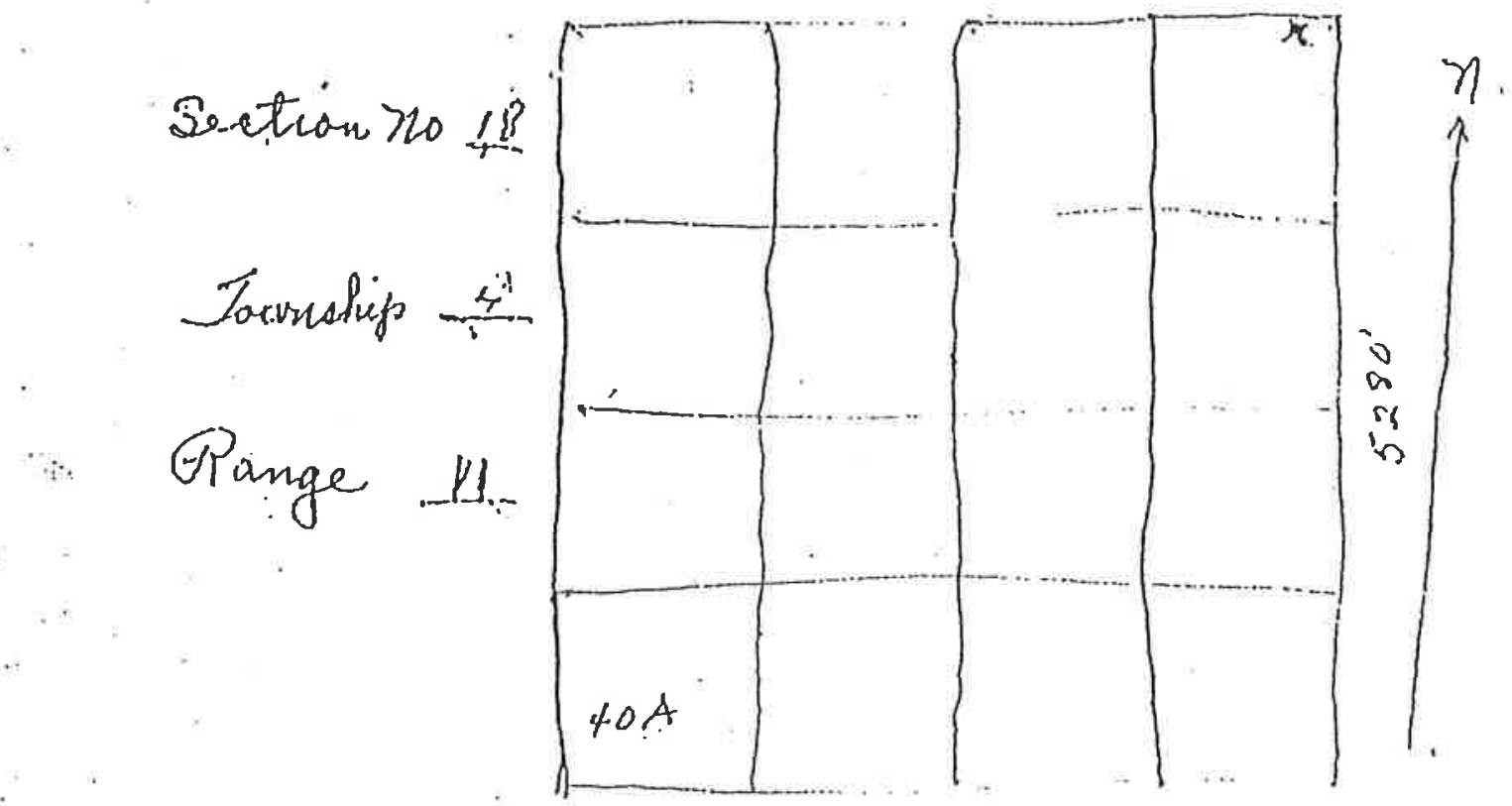




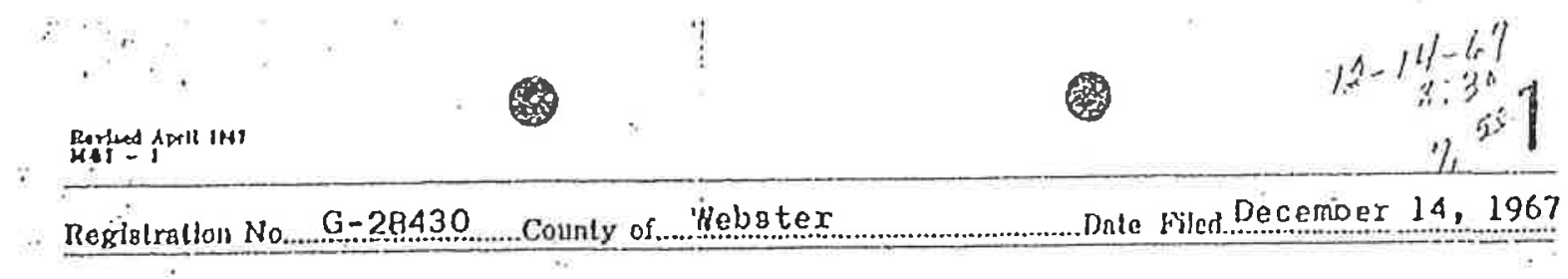

STITE OF NEBRASKA

MUNICIPAI, OR IIRDUSTIUAL WEIJ, REGISTRA'TION

$\therefore$

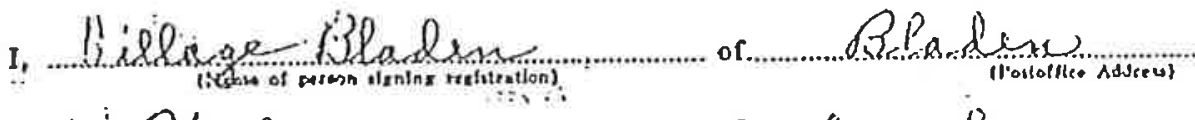

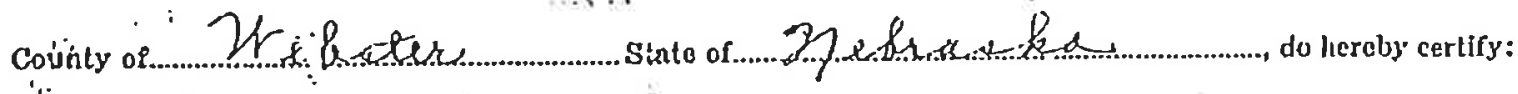

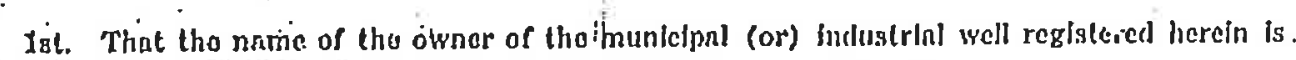

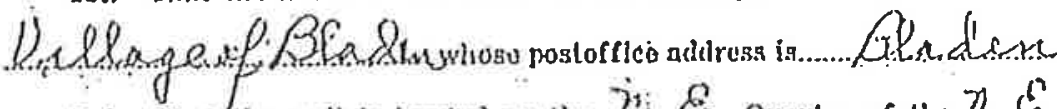

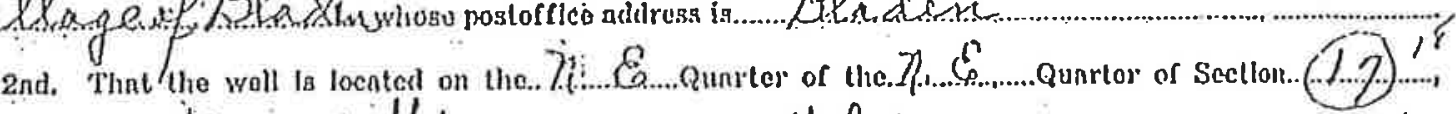

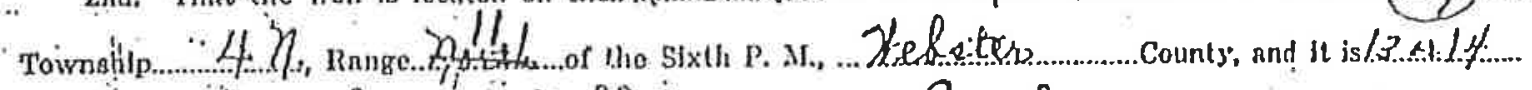

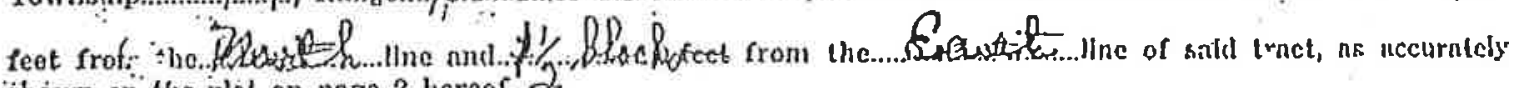
Bhown or the plat on pago 2 hereof. 2 .

3rd. 'That tho.wall was installed for tho following purpose or purposes:

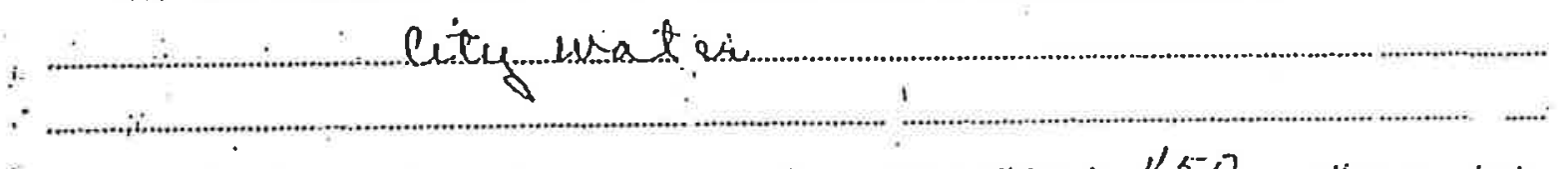

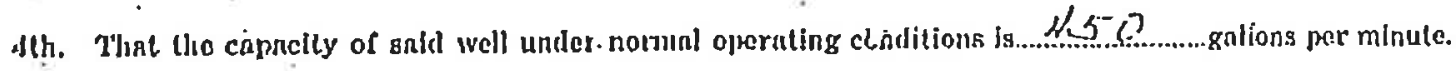

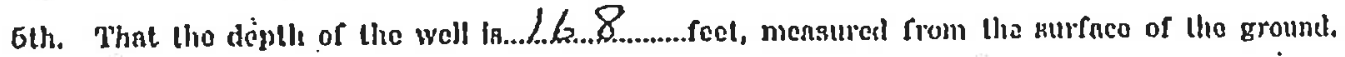

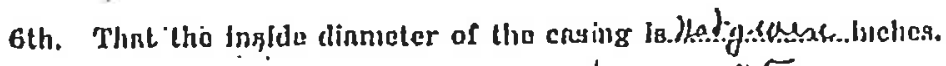

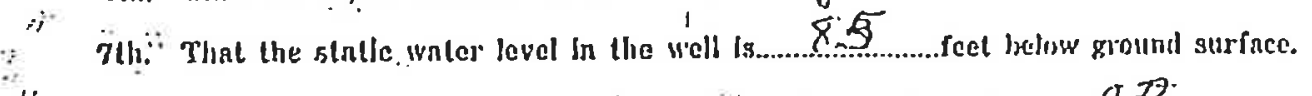

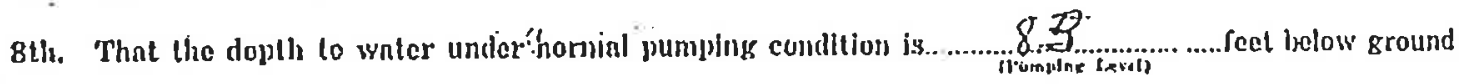
Burface.

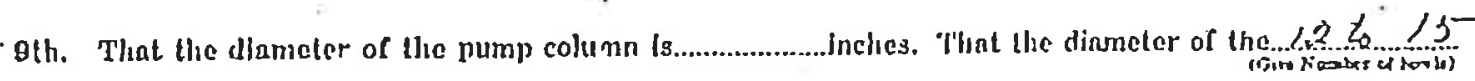

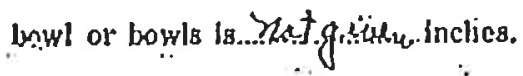

$\because$

IGth. That the type and slze of impeller il' ne follows:

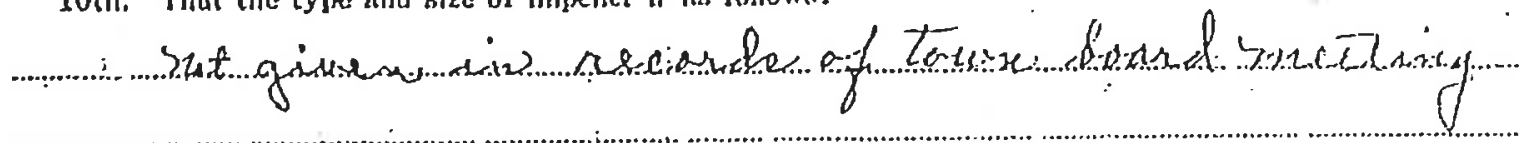

$\because$. Llth. Thiat tho woll war comploted or or nlout tho . Aluy of (l.... 
14

i

Raylerd Aprll 136

6

12th. That uttnelied hereto are three coplus of the lnit of tho well certified to by the driller of the well.

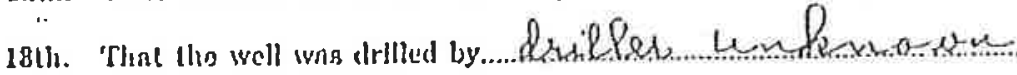
whost ndtress is

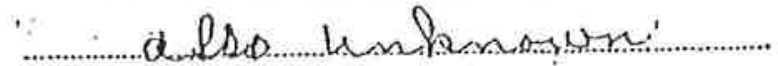

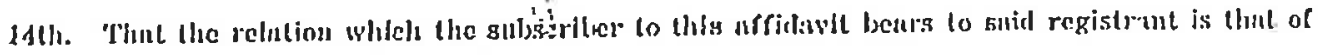

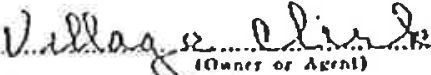

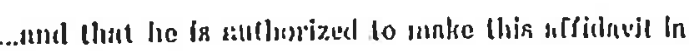
bolin!r of the Interezt affectetl.
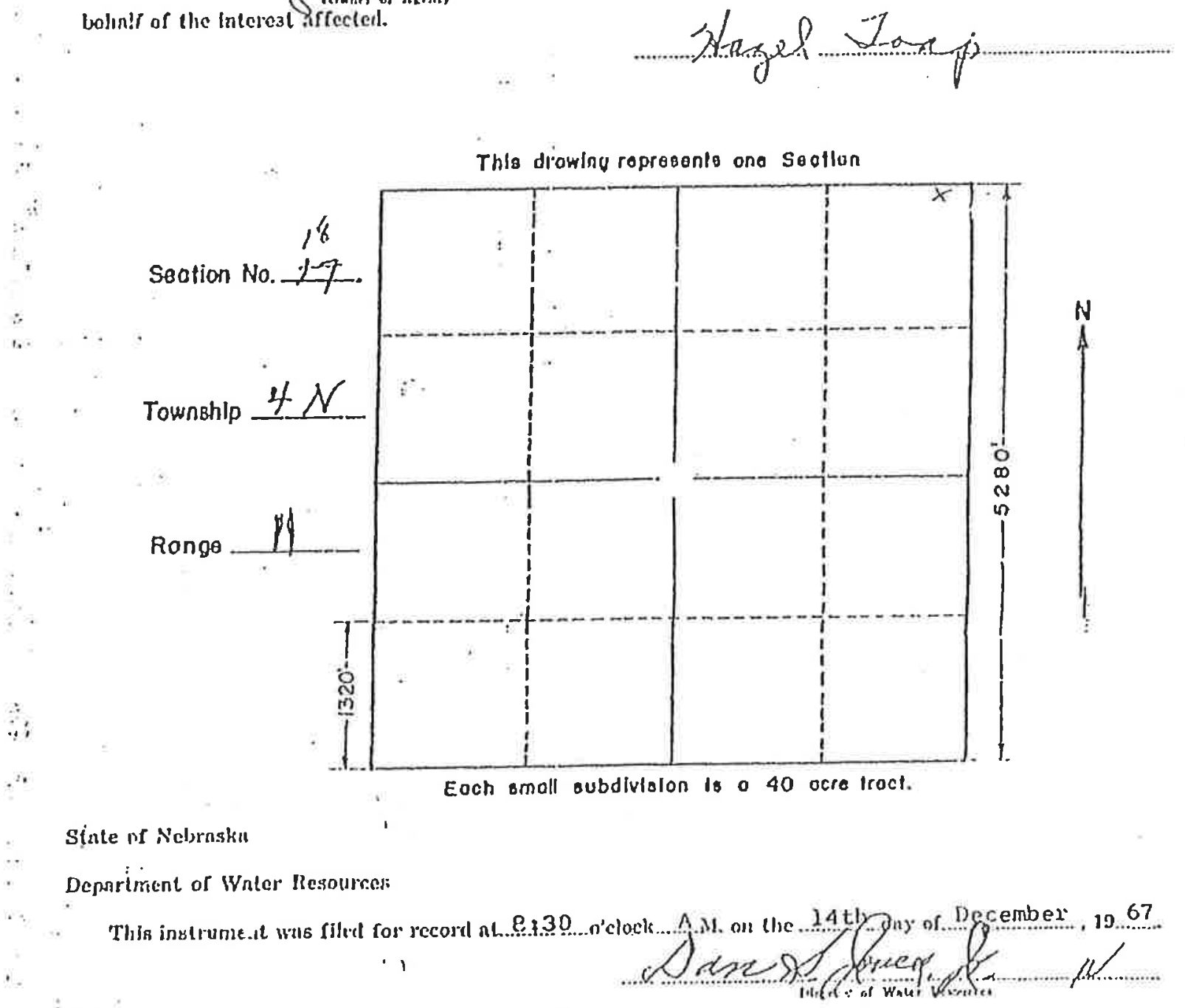

1 
of

County of $\therefore$

1. I am tho driller of a well located on the Quarter, Section No....................... Towrihip....................North, Rengo......................, owned by

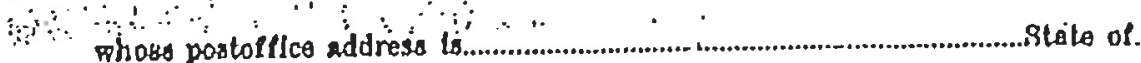

$\therefore \because, \because$ \&. Thiat th drillipg was begun on the...................day of $19 \ldots \ldots$

thif...................... dey of .

ii 8. That thio well is cased and screened In the tollowing manner:

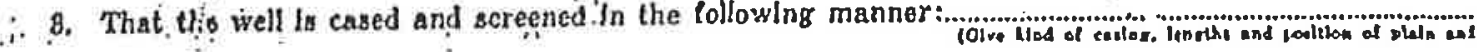

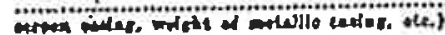
4. That the diumeter of drilled hole ls.................... Inches.

5. That

'i

type of drllling machinery was used.

6. That tho drillod liole is/le siot sealed, as follows:

7. That the following lo an acourato log of the depth, thickness and character of the dicferent atrata ponotratod, and tho location of water-bearing strata:

DEPTH IN EEET.

$\therefore$ FRPM TO . TO

MATERIAI, DRILLED

(n)

. 1

$\therefore$
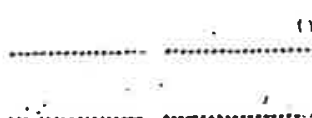

i.

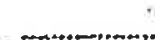

Data Blgniad

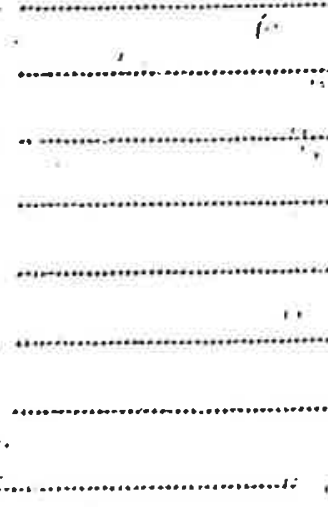
19........, and completed on 


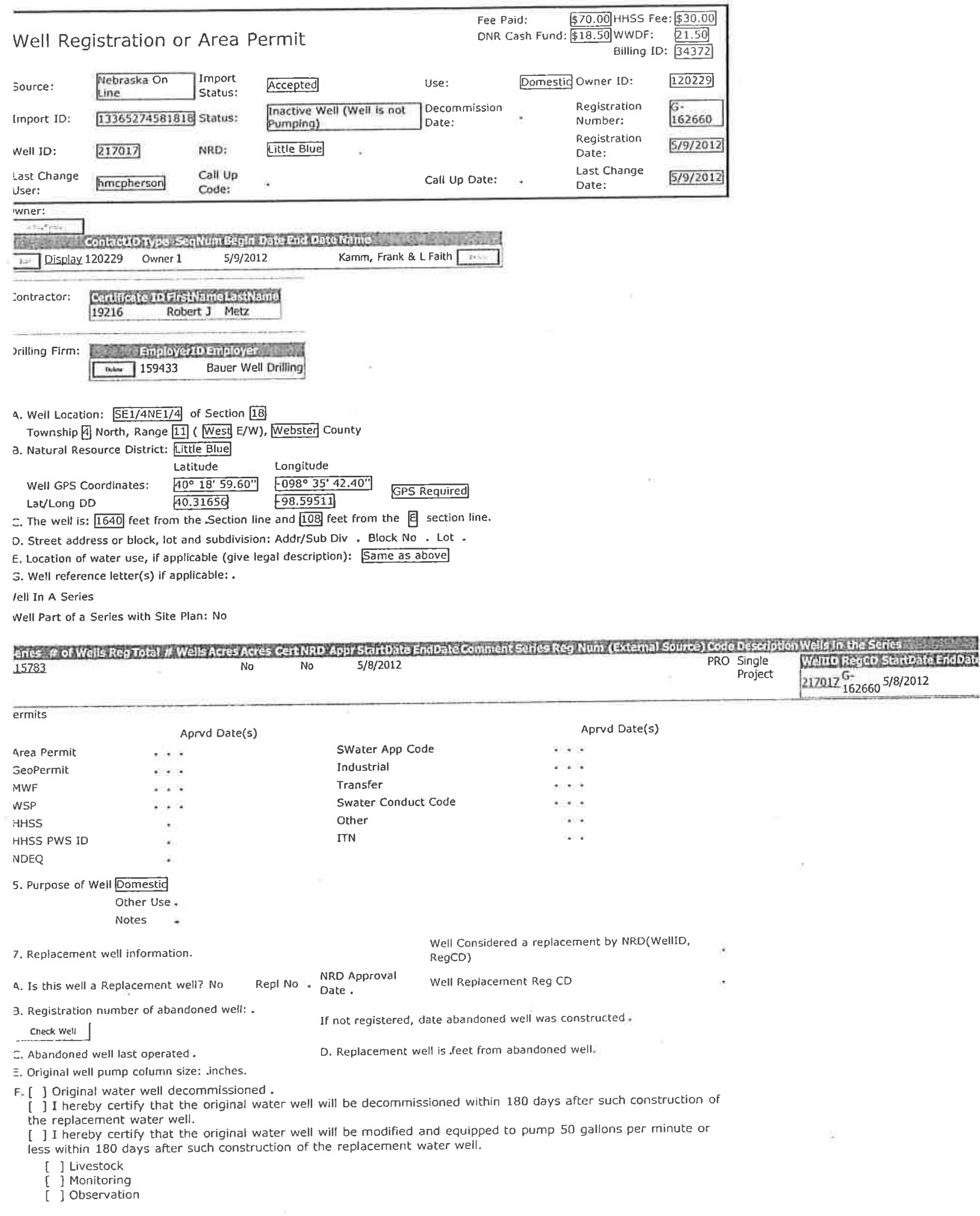


[ ] Nonconsumptive or de minimus use approved by the applicable natural resources district. .

[ ] Decormmission/Modification certification form is submitted by landowner (Must be submitted before registering well)

5. Location of water use of original well: .

Jecommission Information

Jecommission Date: . By

Pump Information.

4. Is Pump installed at this time? No

=ree Flowing Well: No

Pump present but Well Inactive:

3. License No.

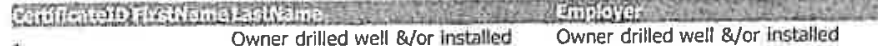

$1 \quad$ Owner drilled well \&/or installed Owner drilled well \&/or installed

¿. Pumping Rate . gallons per minute. pump

E. Drop pipe diameter. inches.

3. Pump equipment installed: .

No

Well active, no pump installed: No

1. This well wll be used to pump less than $50 \mathrm{gpm}$ Y Yes

Well Construction Information

4. Total well depth: 168 feet.

2. Well Construction began: 5/8/2012

E. Bore hole diameter in inches. Top 11 Bottom 11

$\vec{r}$. Casing and Screen Joints are: Glued

D. Well Construction Completed: 5/8/2012

H. Total Estimate Capacity of Well .gallons per minute. I. Pumping water level at capacity: , feet.

0. Well Construction (Casing \& Screen) - c, d, e \& f measurements should be in inches to three decimal places ecord Count $=2$

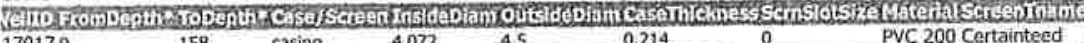

\begin{tabular}{llllllll}
170170 & 158 & casing & 4.072 & 4.5 & 0.214 & 0 & PVC 200 Certainteed \\
\hline 17017158 & 168 & screen & 4.072 & 4.5 & 0.214 & 0.03 & PVC 200 Certainteed
\end{tabular}

are in Feet, all else is in inches

1. Grout and Gravel Pack

ecord Count $=4$

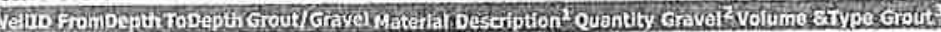

\begin{tabular}{|c|c|c|c|c|}
\hline 170170 & 86 & grout & Bentonite chips & 3 sacks \\
\hline 1701786 & 128 & gravel & Gravel pit & 2 yards. \\
\hline 17017128 & 148 & grout & Bentonite chips & 4 sacks \\
\hline 17017148 & 168 & gravel & Gravel pit & 2 yards \\
\hline
\end{tabular}

are in Feet, all else is in inches

Description of gravel pack, i.e. engineered gravel pack, or gravel pit description (1/4 down) or brand name (best sand) natural yrmation, drilling cuttings, soil backfill

Quantity \#cubic yards, \#Tons, \#Sacks - (for drilling cuttings and soil backfill estimate quantity) Calculation assistance available $n$ web

volume \& Type: \#gallons of a slurry, \#Barrels of a slurry, \#sacks used in the slurry, \#Bags of non-slurry bentonite (chip-pelletranular)

2. Well Geologic Materials Logged

\begin{tabular}{|c|c|c|c|}
\hline 170170 & 86 & Clay & Dense/5tiff Brown \\
\hline 1701786 & 120 & Sand with Clay/ & Soft Gray \\
\hline 17017120 & 128 & Sarid fine-med & Loose \\
\hline 17017128 & 148 & Clay & Dense/Stiff Gray \\
\hline 17017148 & 168 & Gravel & Loose Red \\
\hline
\end{tabular}

are in Feet. 


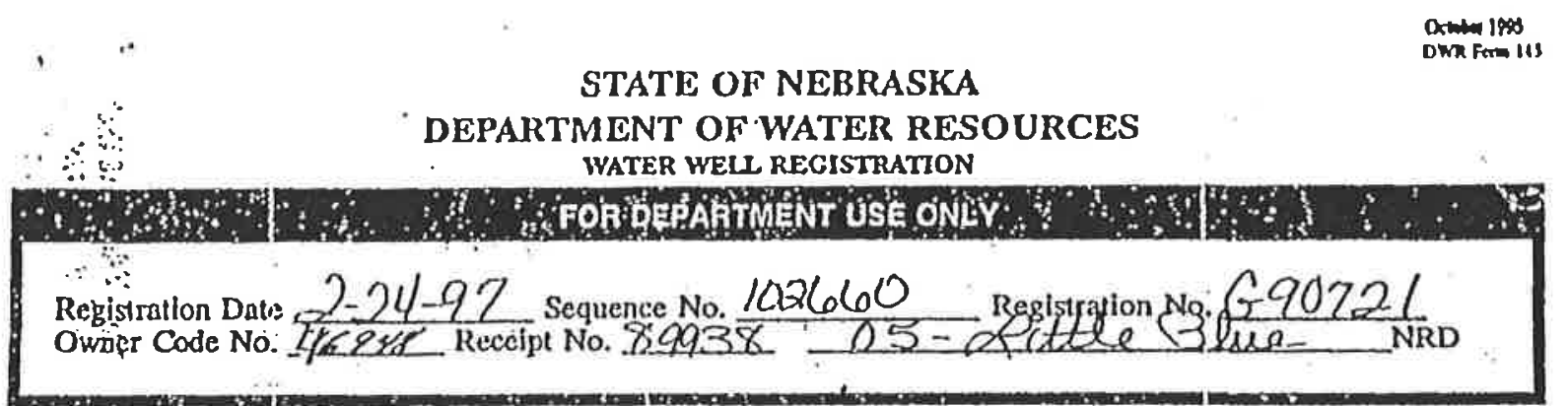

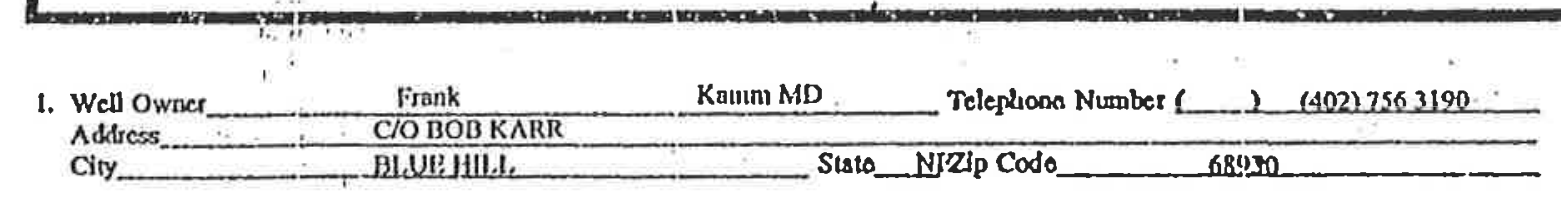

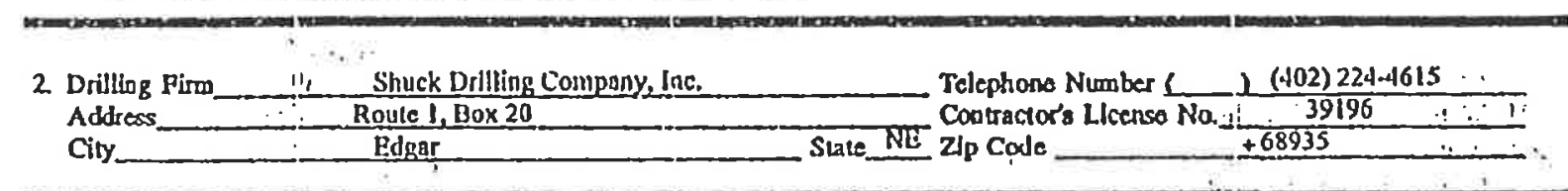

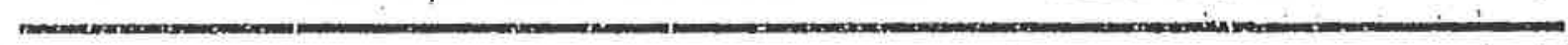

3. Permit Number(s) $\quad$ LBMA-0012

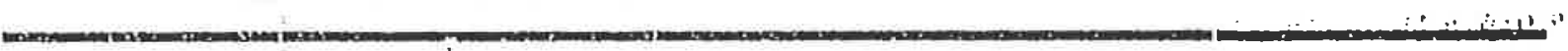

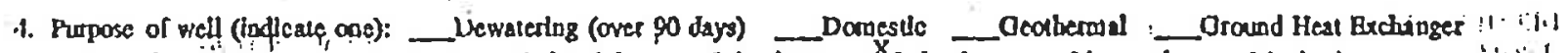

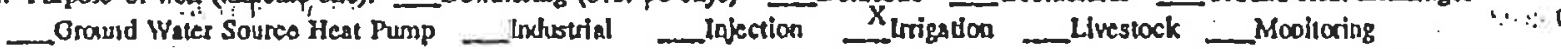

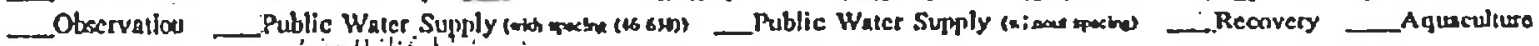
Other

5. Replicement and abaindoned well informalipa.
A. Is the well a repiacensent well?
Yes 'CNo
B. Reglsiration uumber of abandonod well:
C. Replacerient will is fect from abascloned well. D. Atrandoned well last operated

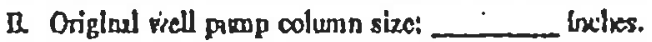
F. Completlon of criginal well slyandonment on 19
O. Loxation of waier use of abandonod uncli:

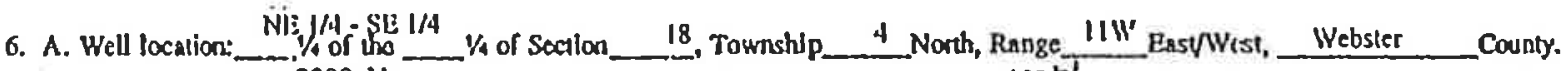
B. The well is ___ $2300 \mathrm{~N}$ fect from the (Atentifor South) section liac and $180 \mathrm{~W}$ feet from tho (Eart or Weat) section lide.

C. Sucet eddiess or block, lot and subdivislon, if applle able:-

D. Location of water ise, if applleable (give Iegal descripalons):

B. If for Lrigation, the tand to bo inrigated is acres.

P, Well referenos tetter(s), If applicable:

7. Punup Inforiantion.

Punip Inforasation
If yes, complete items A through $\mathrm{F}$. Yes

If no, complete ficms $A$ and $D$ with estimated information for those wells in which punip will be instajled.

A. Actual pumping tate, If sprilicablo:

B. Punp column ditumeter: gallons per milnule. Mcasurad $R$

C. Lensth of premp columr

8 inches.

19

D. Brand/Type (Circle one)

P. Punp installed by: Contsector $\square$

Owner D

Pump Installet 0 Llause No.

Estimated D

$160^{\circ}$ Dubine roct 
8. Well Construction IIfformation.
A. Total well degib:
170 recl. B. Stalle water lovel:
93 rect.
C. Mumpling waicr tevel: 120
i.
0 Iistinared of (1) Measured

reet.

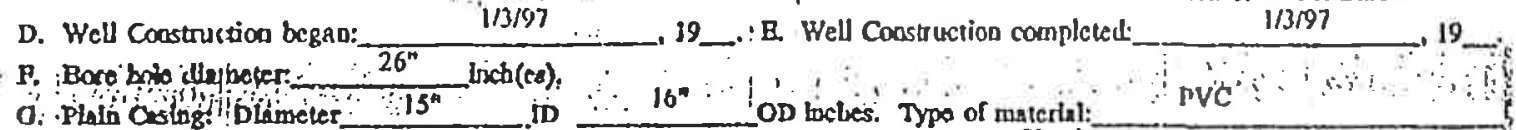

$1 / 3 / 97$

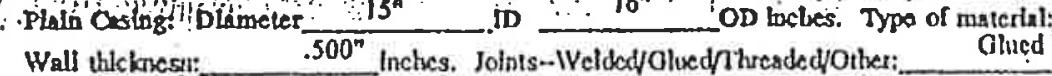

Wall thickesest:_ $\quad .500^{n}$ inches. Joints-IVelded/ulued/7hreaded/Other:

Lenguh(s) and placement(s)' depth! froor

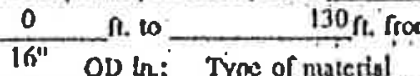
15 "

ID

H. Scricen:

085 " double slat

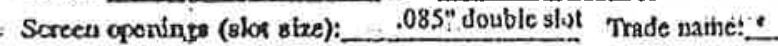

Leagub(s) and placement(s) depth from

I. Oravol pack futerval(B) from

J. Grouted/Sesleal from

10 fit to 170 fit. from

170 at. from

10 fit, with

.; from.

it. to

a. to

$\omega_{-7}$

fl., with.

K. Dilling medudt

Reverse Holary

L. Drilling fuld:

Drilling fluid: (type Vuter

M. Weil devologitient techrique (total timo and mechod):

$X^{N}$. Will chemicals, férillizer or antfreeze be injected or utilized in the system?

$X$, If $; c s$, what will bo used:

9. Oeologic Mtapertals Lipged.

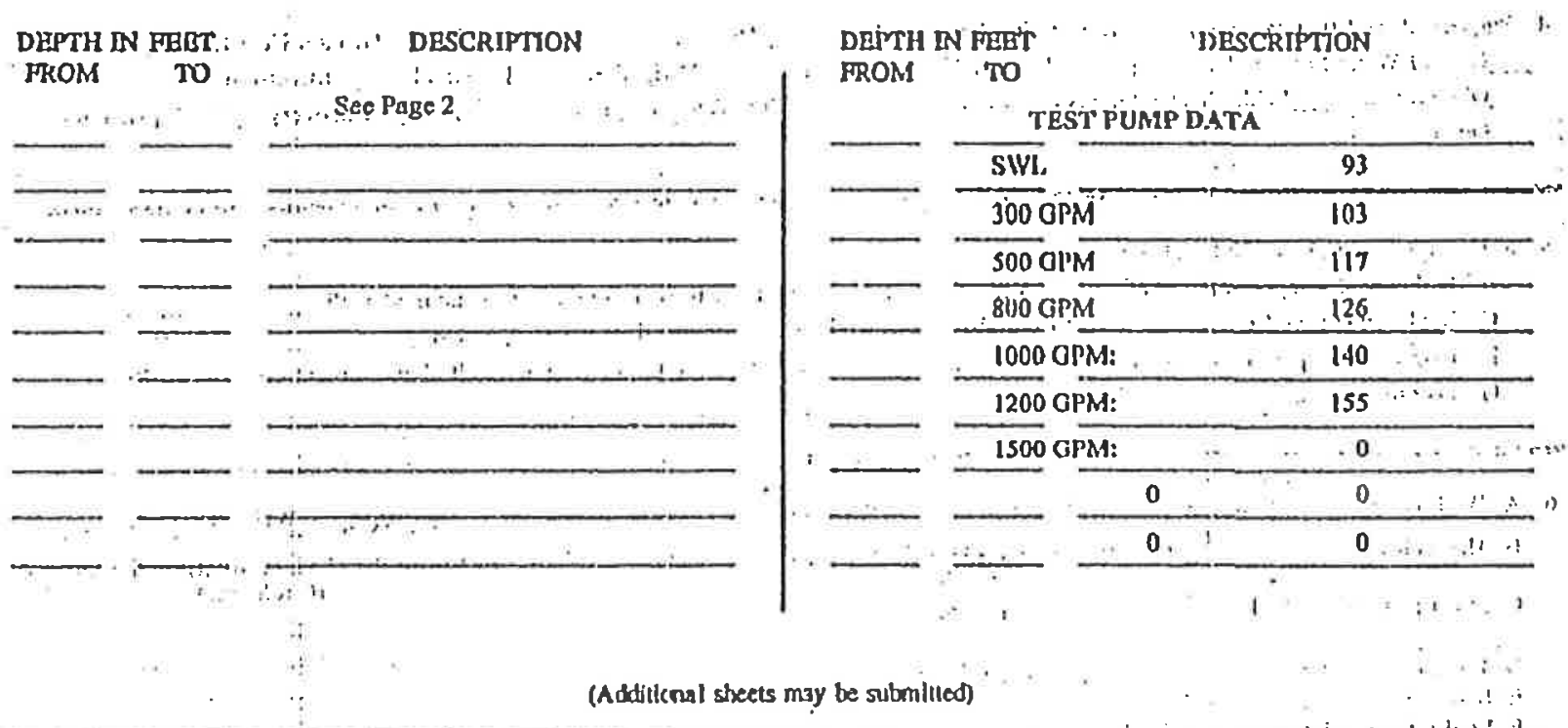

(Additicnal steets may be submilled)

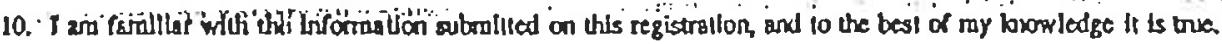

Ouldes at $1 \%, 16 i$ in

s. Orado sizc: - . . .

Clay end Bentọnto

(typo)

Yes $X$ No 

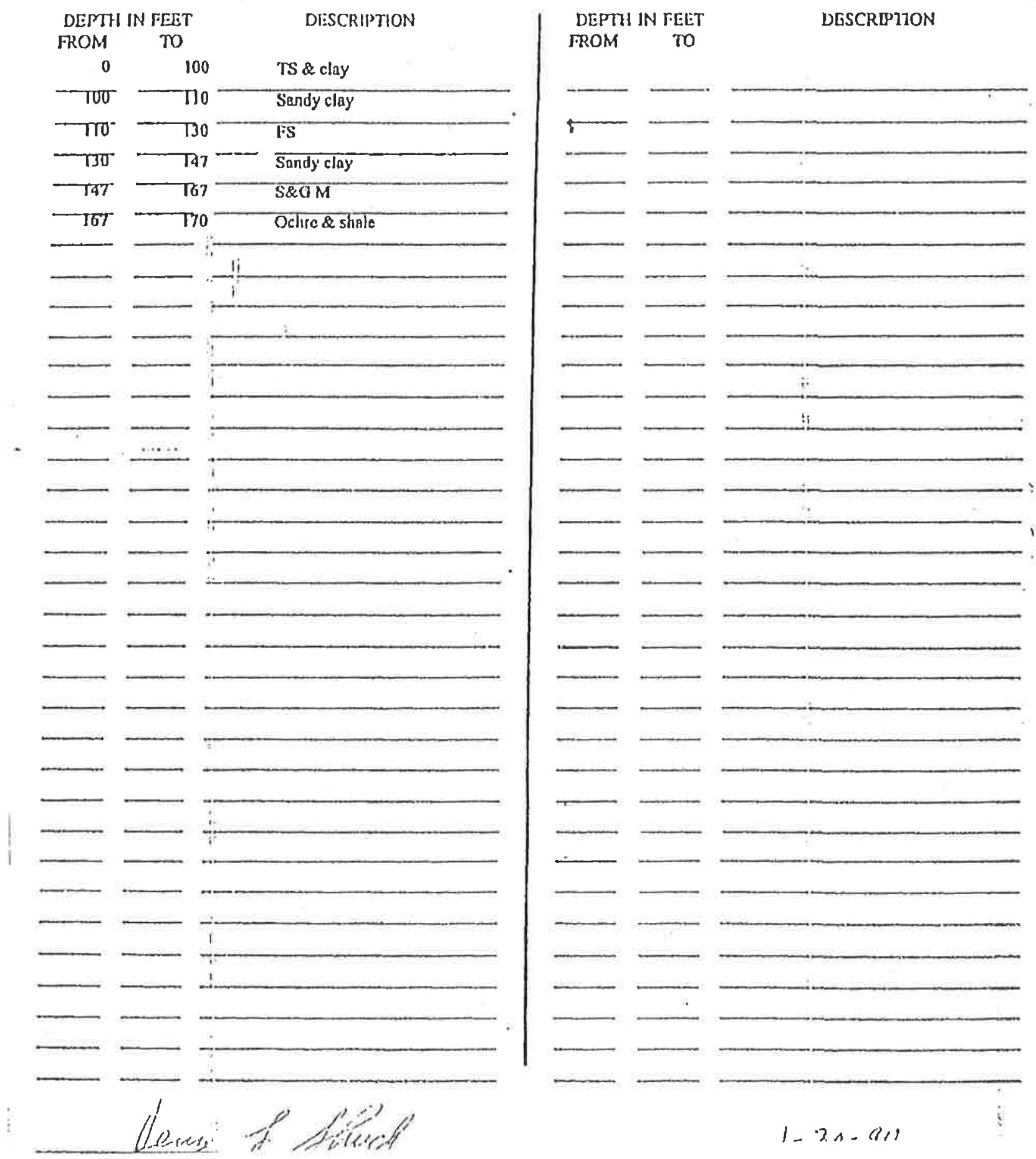
STATE OF NEBRASKA

\section{DEPARTMENT OF WATER RESOURCES}

IVATER WELL REGISTRTION

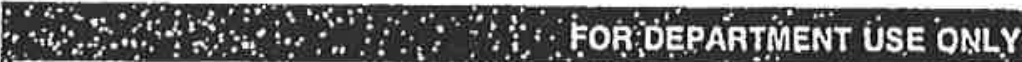

Registration Date 7-20-1999 sequence No 19321 . Registration No. G-101320 Owner Code No. 53707 Receipt No. 12255

1. Well Owiner Dautd M. Lasifiman Telephono Number $14021756-1360$

Adures Re 1 Box 96 City. Bladen Stat NE Zip Codo fos $92.8+$

2. Drilling Fim MARuHN Well Drill.n Adtress $R \times 1$ Bel 27 City Re Claud

Telephono Number (4) 14 Y4 3523

Contractars Licenso $\mathrm{Na} 3923$

V 3. Permit Núnber(s)_, $4^{\prime} 4$

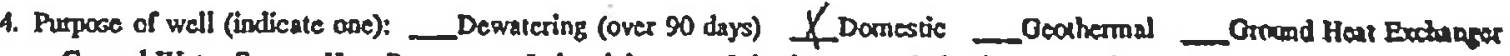

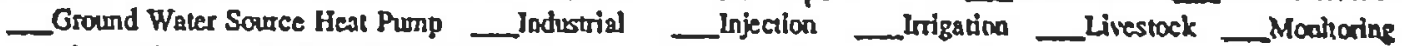

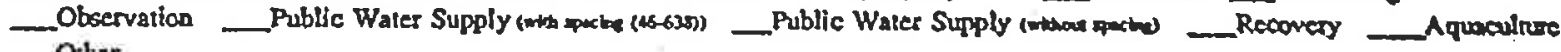
Otber

(toticien (us)

5. Replacemens and abardoned well information.

A. Is this well a replacement well? Yes X. No B. Registration number of abandoned well:

C. Replacernent well is feet from abandoned well. D. Abandoned well last operated inches.

P. Corsplation of ariginal well atuodonmens on

19

E. Original well pump column size:

C. Locadon of pater use of abandoned well:

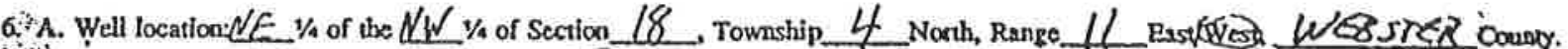
$\checkmark$. The well is 180 feet from the (Norhtor South) section line and 1878 C. Street address of block, lot and subdivision, if applicable: $R_{+}+R_{3} \times 96$ foet frem the (Eest of Weat) yocrion line.

D. Location of water use, if applicable (glve legal descriplions):

iB. If for infigation, the land to be irrigated is

S. F. Well refetence letter(s), if applicable: acres.

7. Promp Information.

Is purnp instailed at this time? If Yes

If yes, complete items A through $F$.

If Do, complete irems A and D wilh estimated infonmation for those wells in which pump will bo insulled.

A. Actual pumping mite, ir applicable: 20 gallons per minute. Messured R a Esuimatod D

B. Pump column dinneter: $\quad I / 4 \quad$ inches, C Length of pump column: $j 0$

D. Pumping equipont installed:_b-3U (Cincto out)

P. Pump installed by: Contractor $\theta$ Owner 0 Pump Insaller a Lioeroo Na_3913/ $\because \cdot$ 
8. Well Construction Information.

A. Toul well depth: $\quad 130$ S) Coes

B. Stalic water level: $54^{\circ} 5^{\circ \prime}$ foet.

\section{$0-101320 \ldots$}

$d$ Estinatad of $\square$ Mearmod

D. Well Cacseruction began: 6.21 1992 E Well Construction cornpleted 621 .1987

P. Bore bole dismeler: $91,0-19$ inches. $24,19-180$

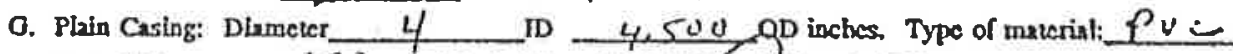
Wall thickness: $\quad 1 / 73$ inch(cs). Joints-Welded/6luch/Threaded/Oiher:

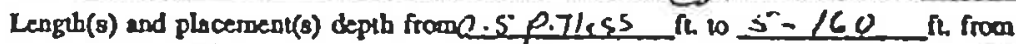

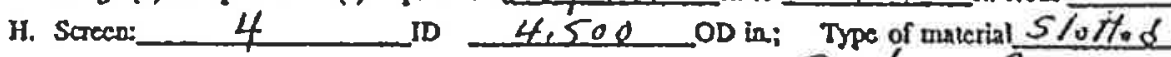
Screen operings (slot size): 0020 Trade nane:Erigle Pacific. Lengeh(s) and placement(s) depeth from 160 in to 190 in from in ourdes al 160 in.

I. Gravel pack inerval(s) from 17 in. to 180 it. from

J. 'Oroutcd/Scaled from 5 [t. to to 19 ft., with ir. to

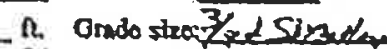
from. f. to fi., with

K. Drilling method:_LoTary L. Drilling fluld: $\Delta<t_{u}=5$ I (के)

M. Well development technique (total time and method): $a$ in

N. Will chemicals, fertilizer or andfreeze be injected or utillzed in the systern? ___ Yes $\ldots$ No If yes, what will be used:

\section{Oeologic Msterials Logged}

\section{DEPTH IN FEET \\ DESCRIPTION}

$\frac{0}{90} \frac{90}{144}$
$\frac{144}{182} \frac{183}{185}$
183
$\square-$
EROM TO top soil \& clay's Sandy clay Sand \& 6 raval Dehre shale

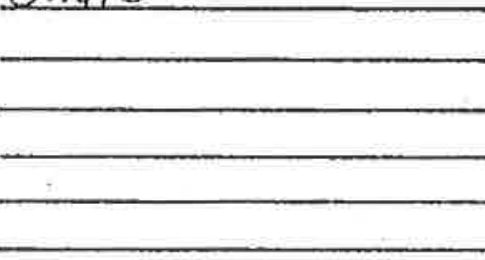
DEPTH IN FEET FROM TO

DESCRIPTION

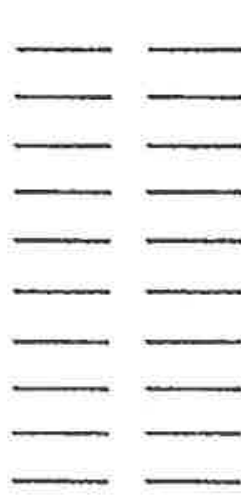

(bop) 烈 


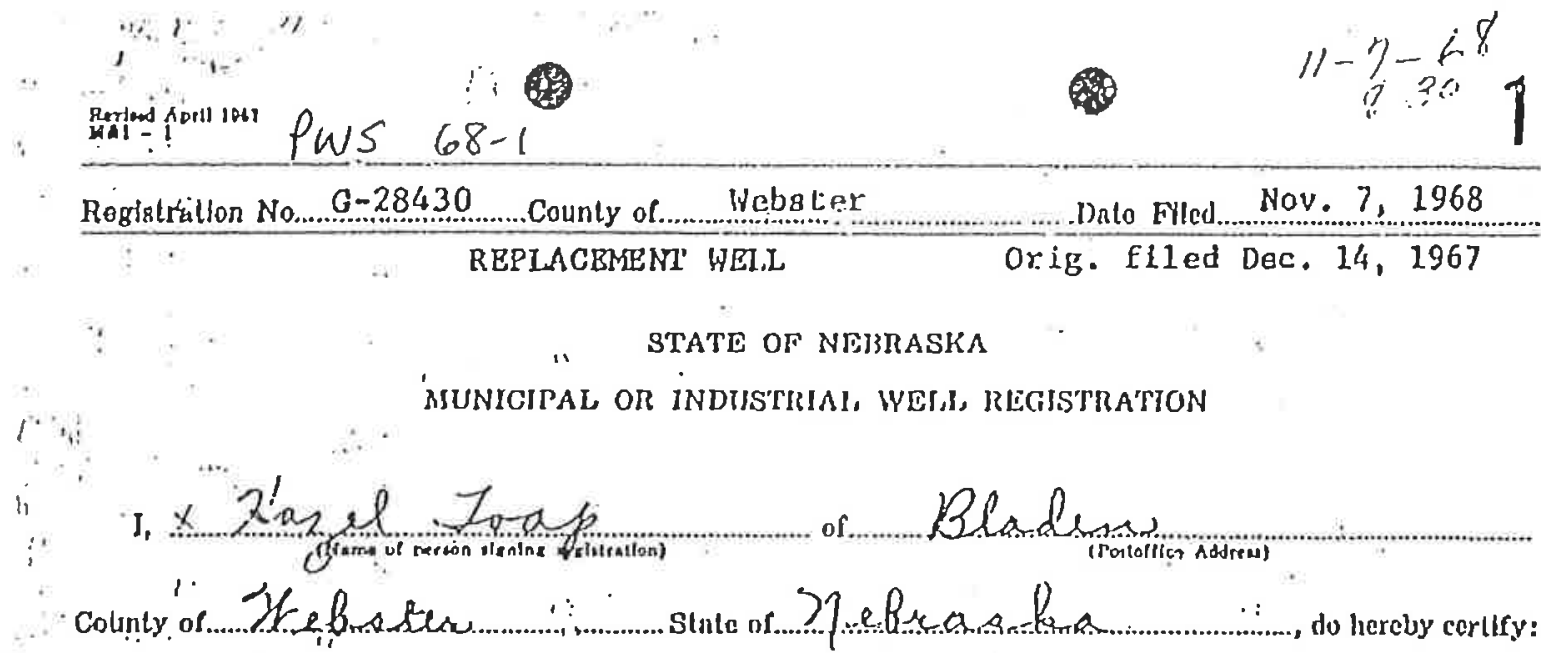

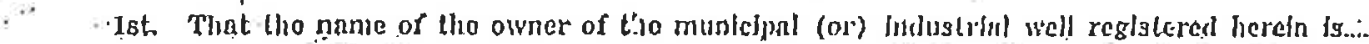

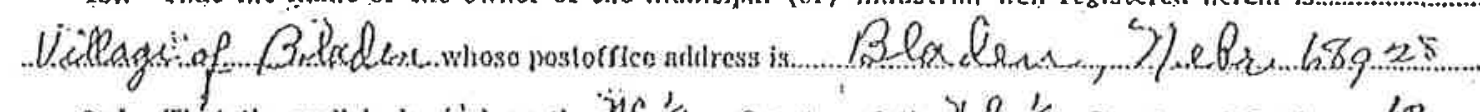

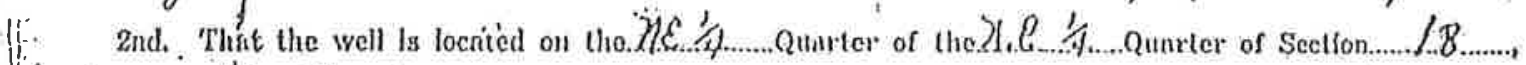

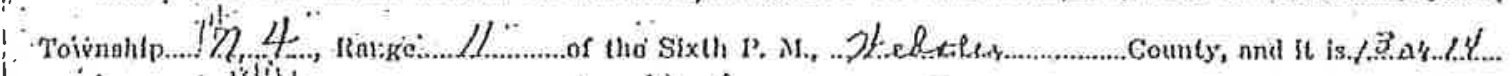

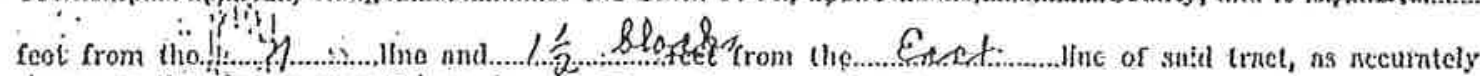

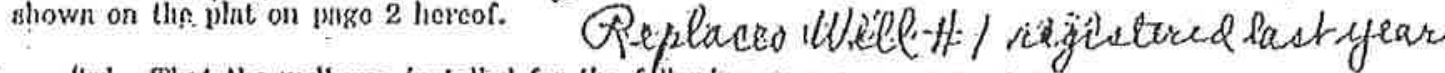

Srd. That the well was instalied for the following murpose or purposes.

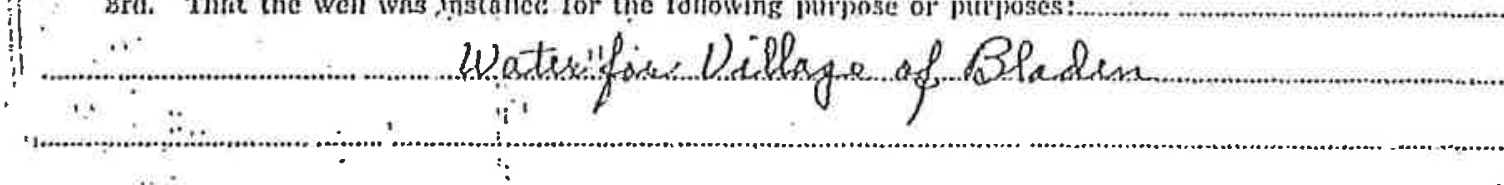

dti. That tho cruscelly of sald well under normnl opernting conditions is......500...........gnllons per minule.

Eth. Thut tho depth of the uell is........ 699 .........feel, mensured from the sutfree of the ground.

61!1; That the Inslde dinneler of the casing is...........18 ...... .inches.

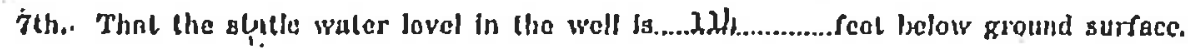

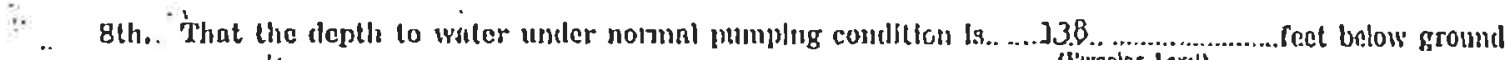
suifince.

$\therefore$.

9th.. That the dfameice of tho pump column is....... hi..5/8.inches. 'Thut the thlameler of the......? Lofil or.bowla is.................... Inclies.

10th. That the type nnd size of impeller is fls follows: $\therefore$

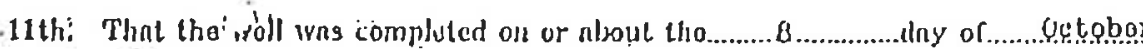
10.60 

-

12th. That nllachel heroto are three coples of tho log of the well certlefed to by the Jriller of the well.

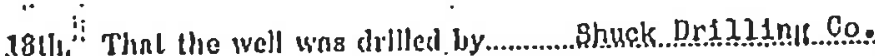
whose nddress is indear. is.tebr.

14th. Thiat the relallon wilich the sübserbegr to this affidavfl benrs to snld registrnnt is that of

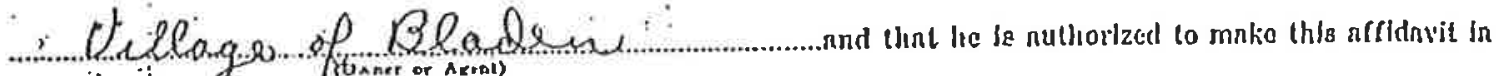
ichinlf of lijo inferest affectesi.

.,$\cdots \cdot$
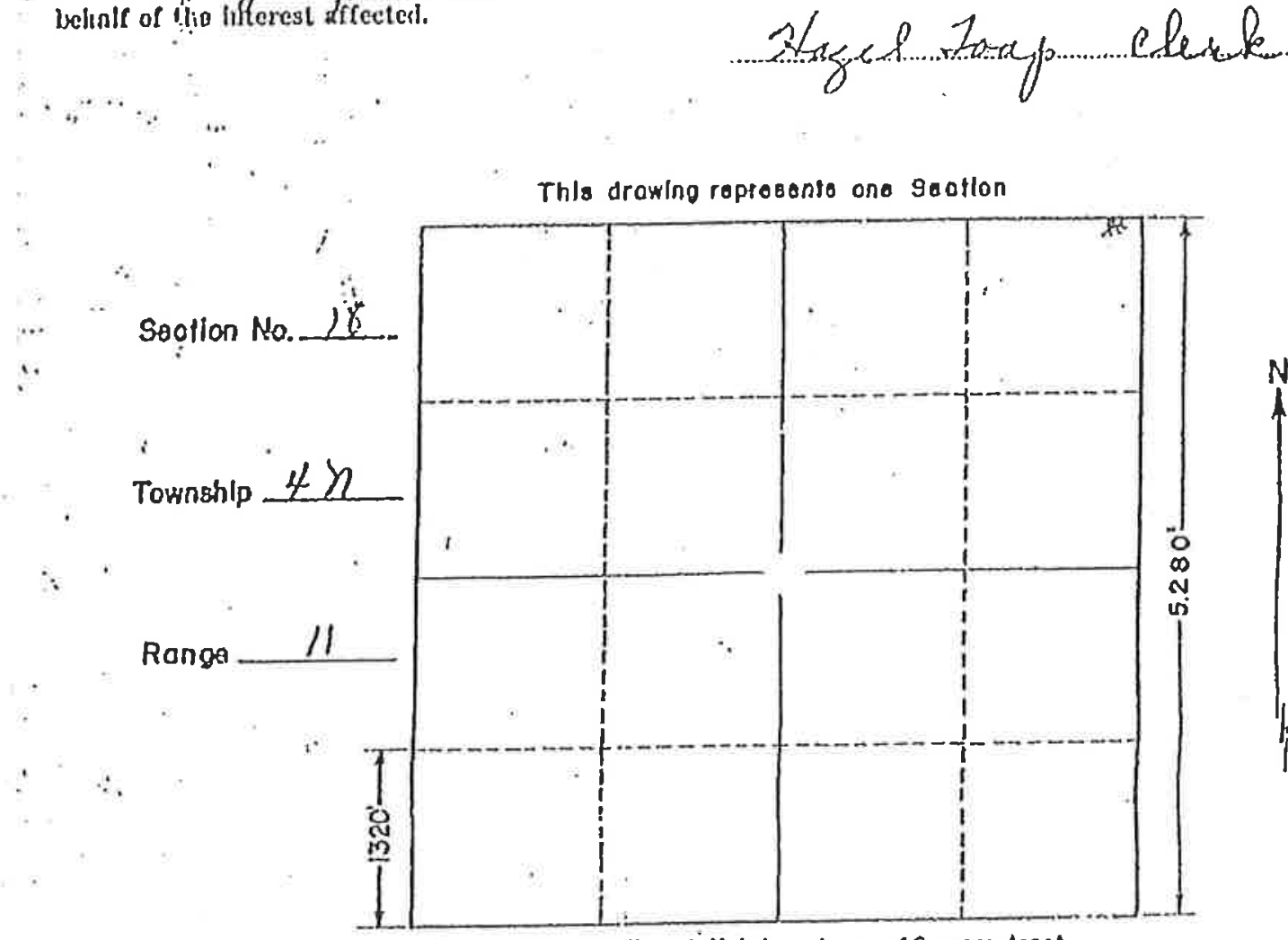

$\therefore$

Eoch smoll subulviaton is a 40 ocre lroct.

Stalë of Ṇebrakn

Iepariment of Water llesuuress

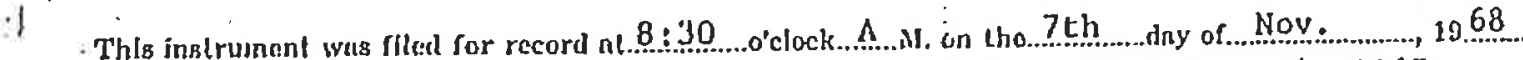
REPLACEMENI WEJL OrJG IIled feg, 14, 1.967 


Roming Aprl 1, in

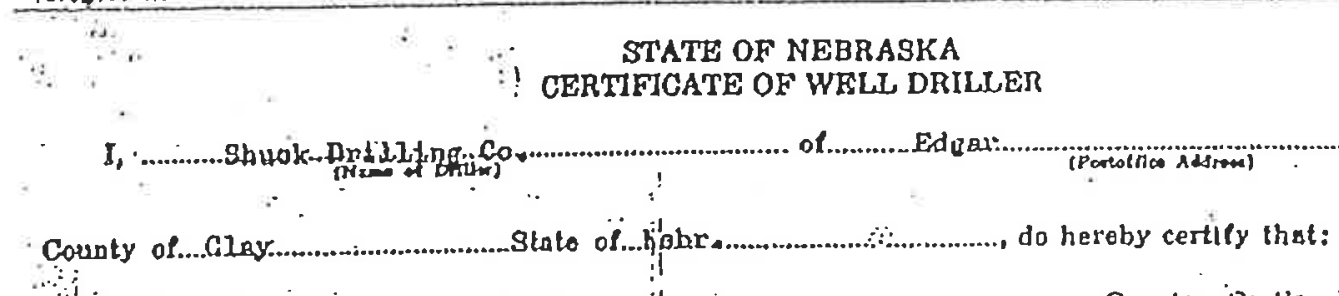

1. I am the driller of a woll located on ilic.... Quarler, isection No...

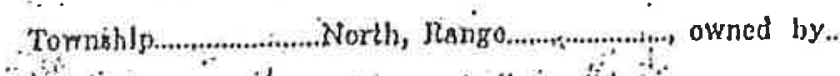

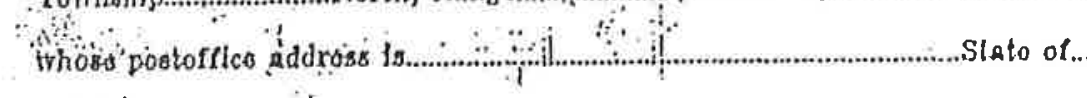
$\because \because$ "Thint tho drilling was bogun on tho... day of. $10 \ldots . . . .$. and conipleted on

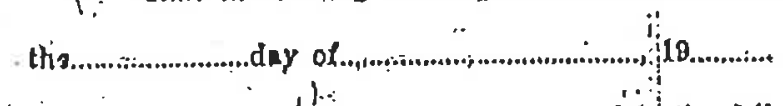

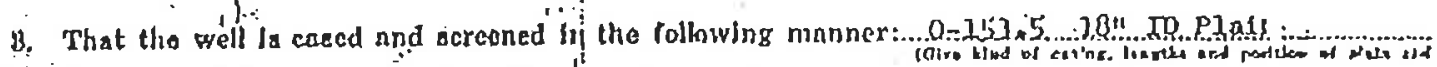

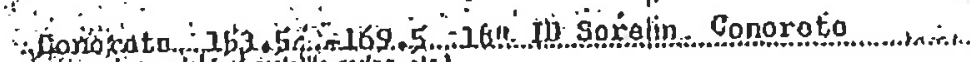

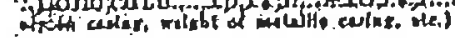

$\therefore$ d. That the dlameter of deflied hole 8 s...... 36 ..........Inches.

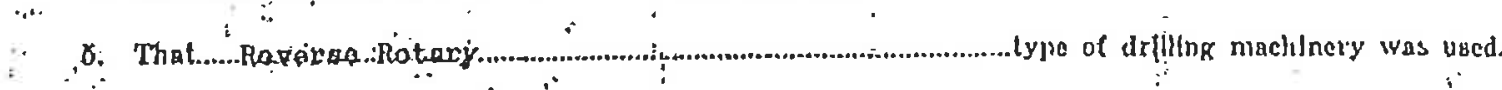

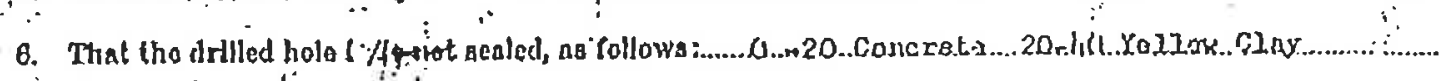

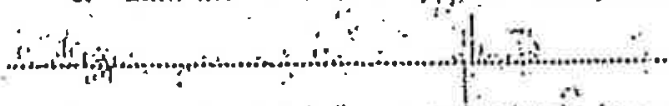

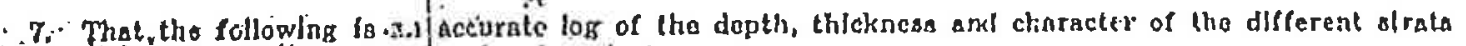
penotratod, and the locitson of wator-benting otrata:

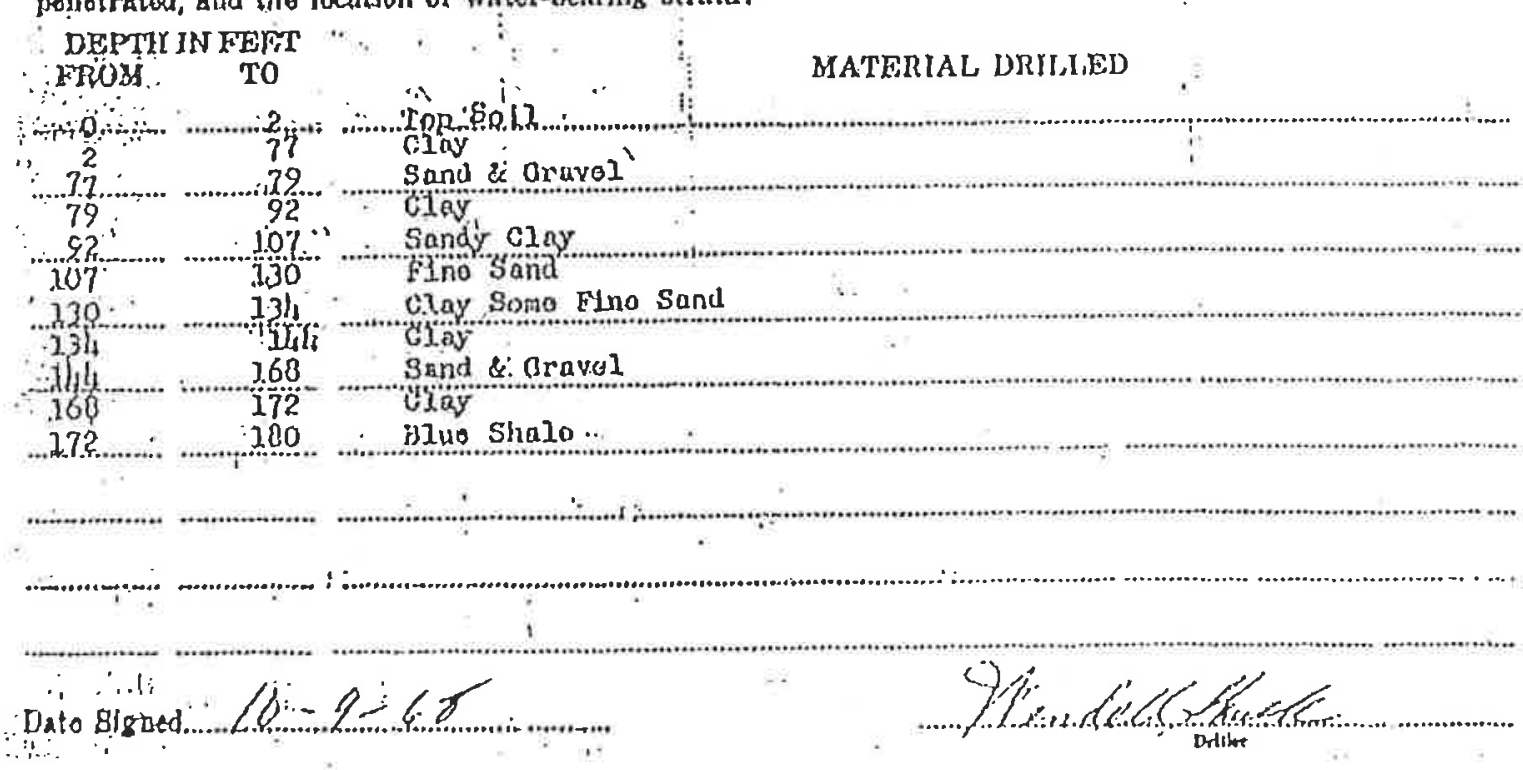




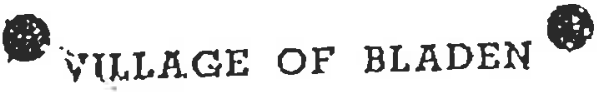

AI.AIIRN, NI!IRASKA

Tha Villago has a socund soll but alltho inforintion availabldis as

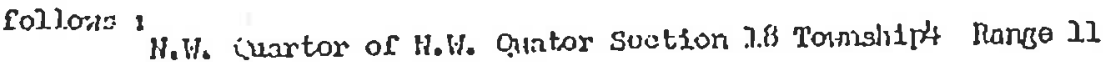

Doptl $: 168 \mathrm{rt}$.

146 It 10 inchos to tụfi of azroon.

2 soot 2 incili soroon

8s root wator in roll.

8.) Leot to wator !

$\therefore \quad$ j.2 to 25 borlis 1

1450 Balzons por nimuto.

- Jakes fromi taun board mecting spariutes dated Qetaber 1430

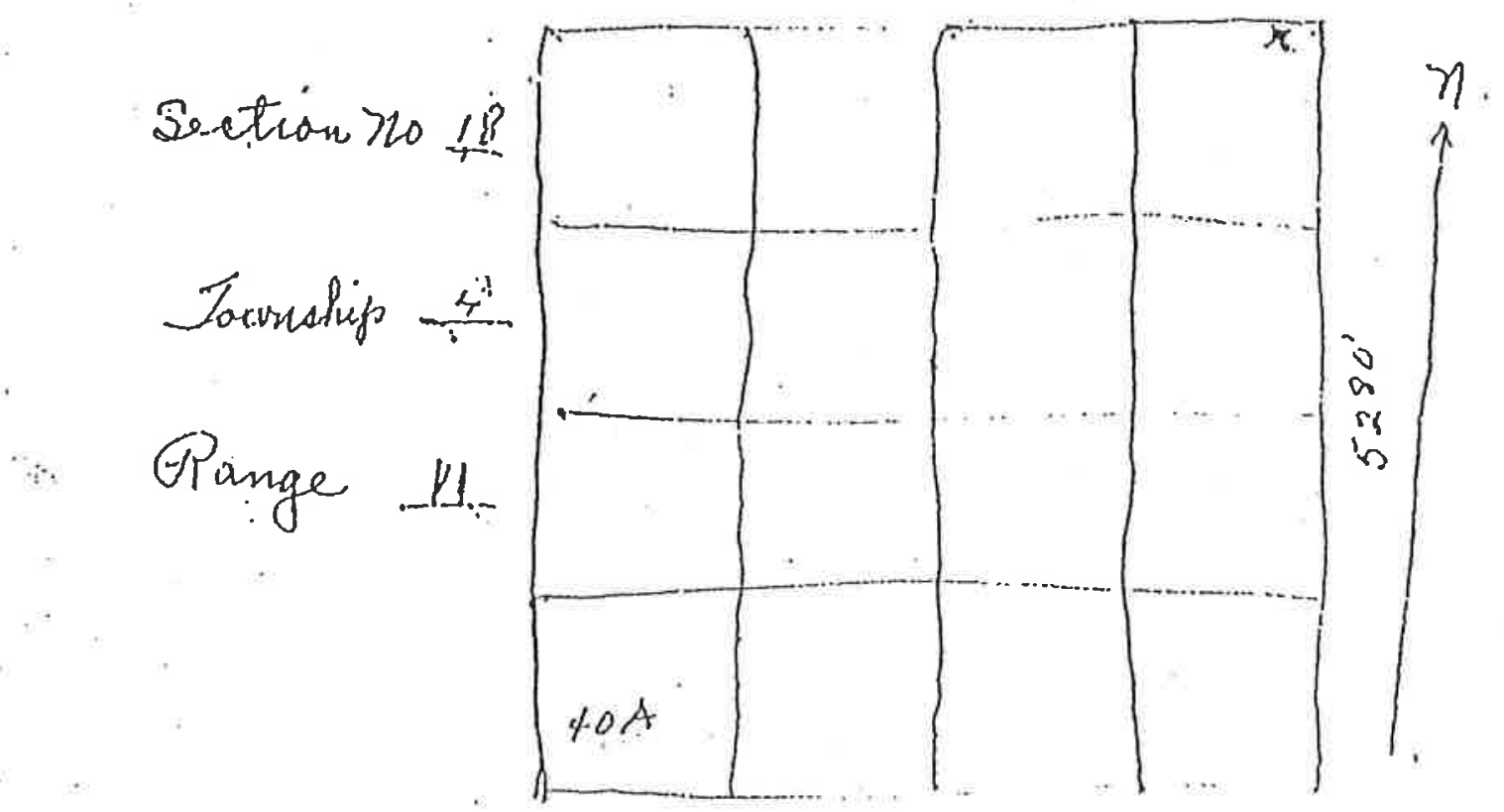




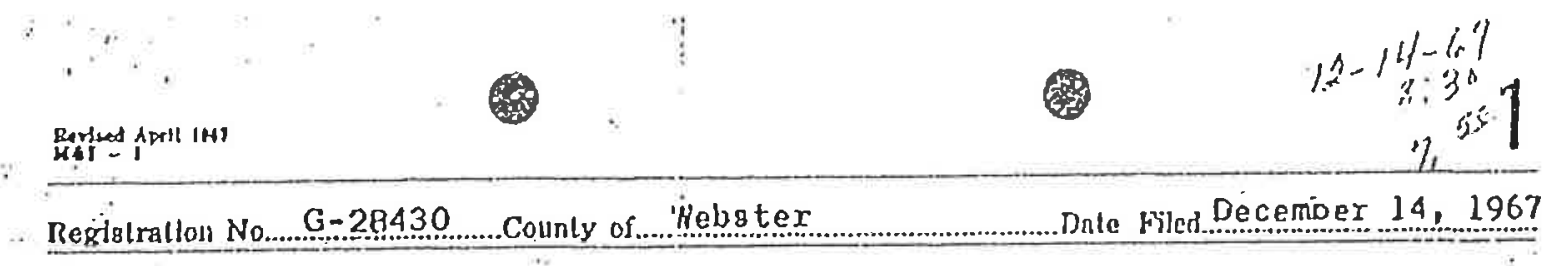

STATE OF NEBRASKA

MUNICIPAI, OR IHDUSTIHAL WEH, REGJSTRATION

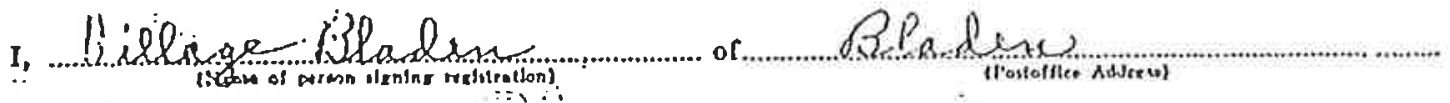

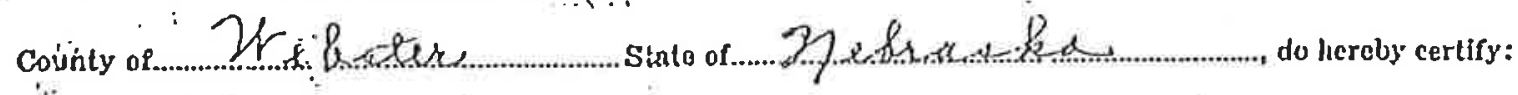

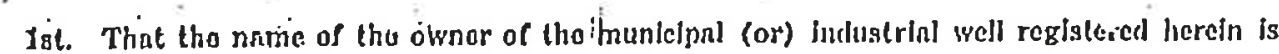

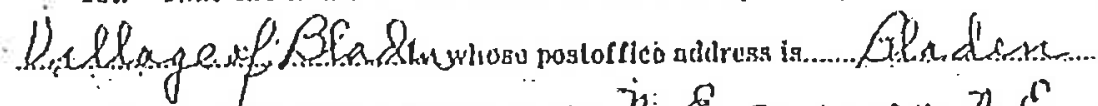

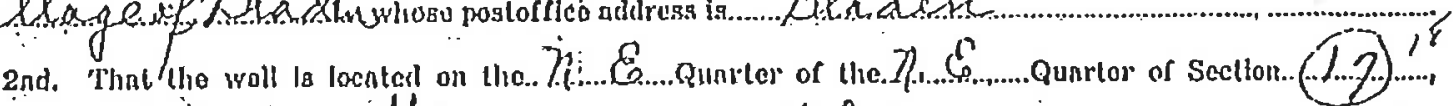

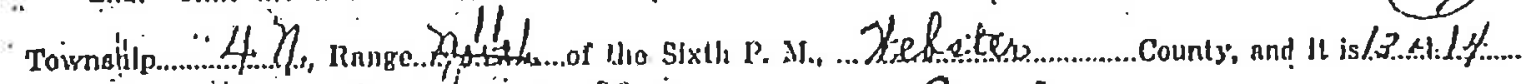
teat frof: ahown or the plal on pago 2 hercor. 2 .

"3rd. 'That tho.wall was installed for tho following purjusn or pur|poses:

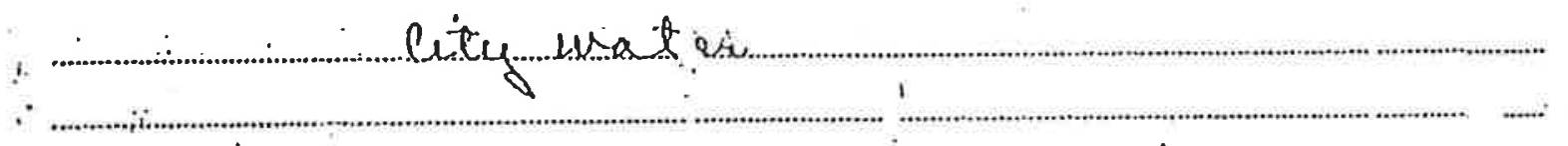

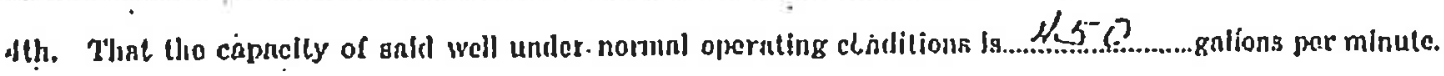

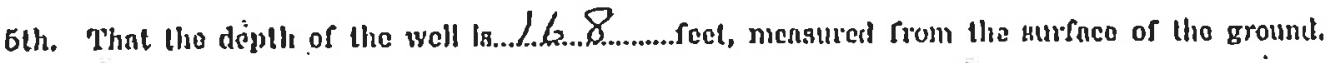

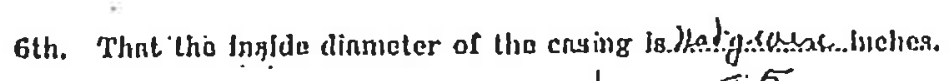

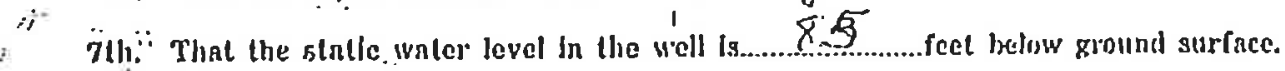

$\because$

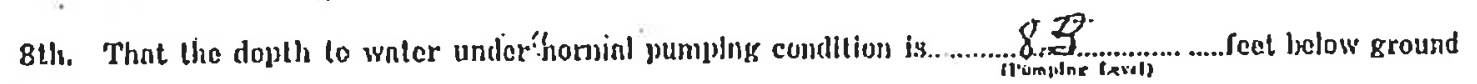
qurface.

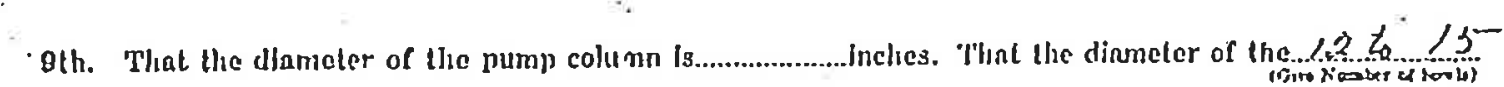

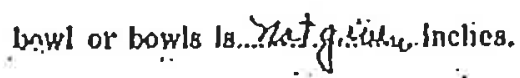

IGth. That the type and size of Impeller li' nB follows:

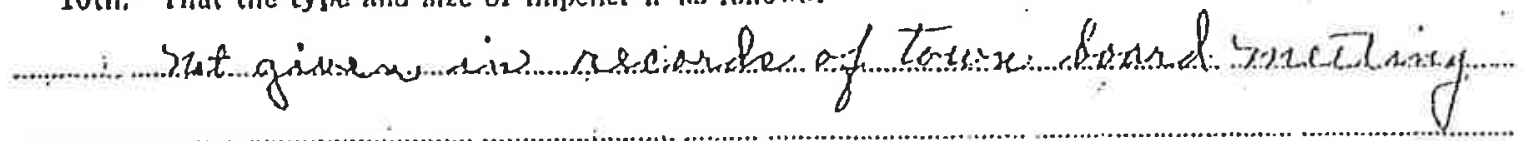

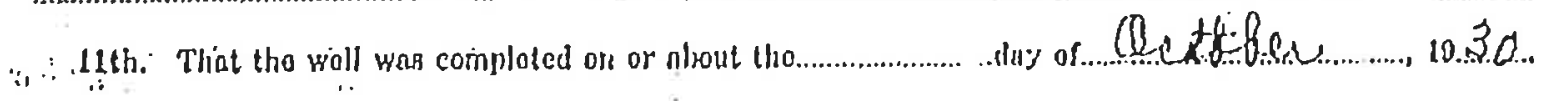




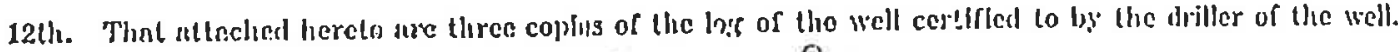

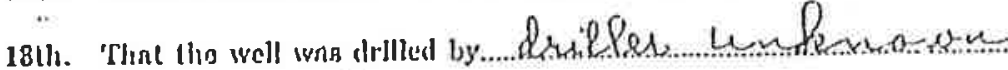
whose adtress is

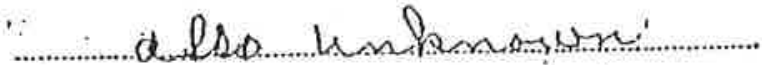

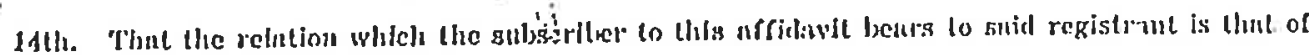

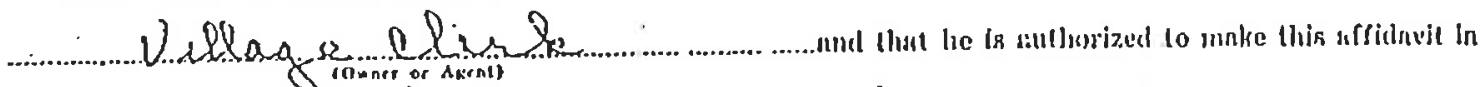
bolin!r of the intereal ?rrecterl.
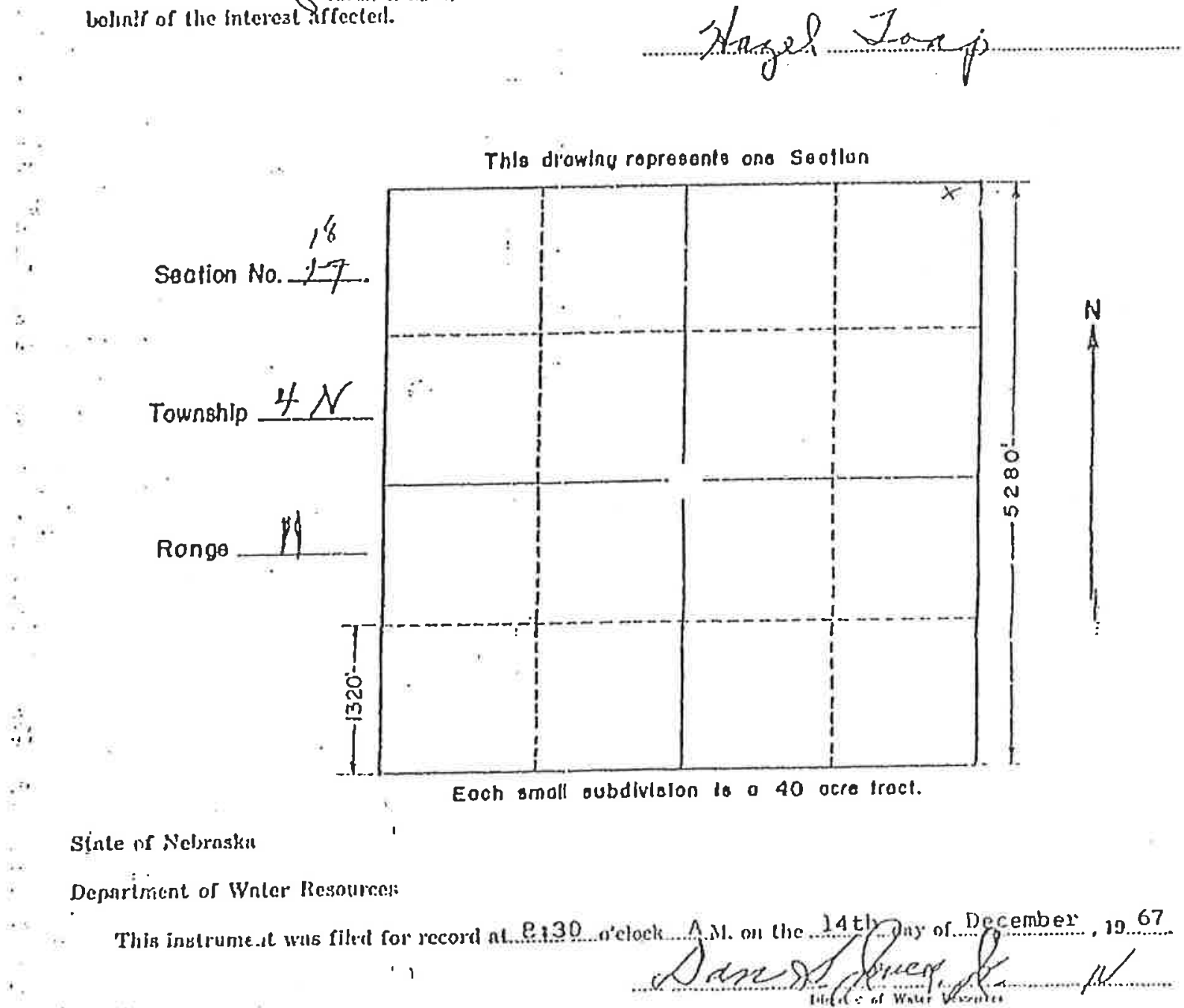

:. 1 


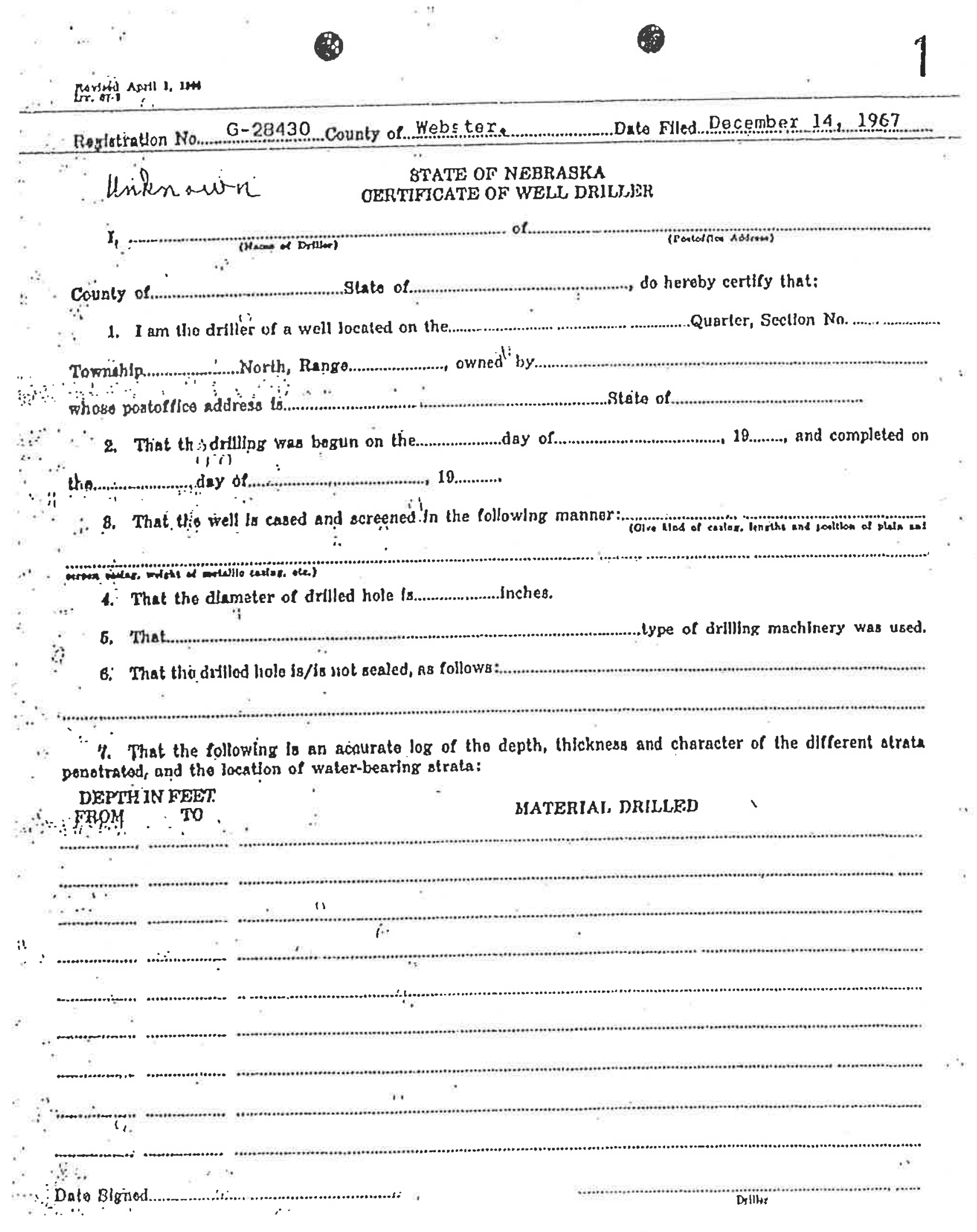


Return to Suirch Page

Nebraska Department of Natural Resources

Database Through: 5/12/2014

Processed: 5/13/2014 1:36:12 PM

Registration Number G-007410, Well ID 11752

Geo Logs

\begin{tabular}{|l|l|}
\hline FromDepth & ToDepth \\
\hline
\end{tabular}

\begin{tabular}{|l|l|l|l|l|}
\hline 0 & 5 & TOPSOIL & & \\
\hline 5 & 110 & CLAY & & Other \\
\hline 110 & 124 & SAND & & Other \\
\hline 124 & 155 & CLAY & & Other \\
\hline 155 & 173 & GRAVEL & & Other \\
\hline 173 & 176 & SHALE & & Other \\
\hline
\end{tabular}

Casing and Screen

Grount and Gravel 


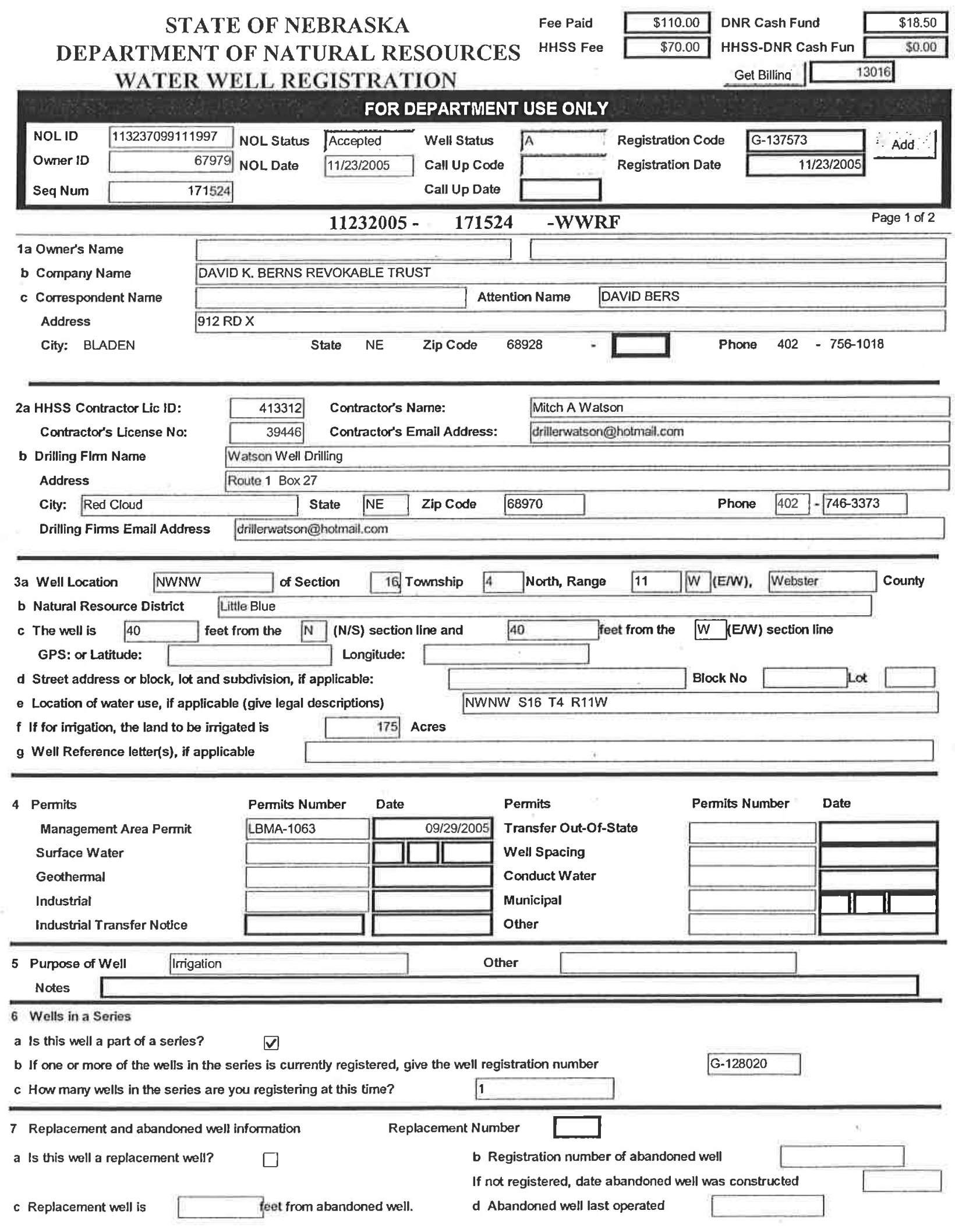




$\begin{array}{llll}\text { e Original well pump column size: } & \text { inches. Completion of original well abandonment on } \\ \text { g Location of water use of abandoned well } & \end{array}$

8 Pump Information

a Is pump installed at this time?

Is pump installed by well owner in section 1? $\quad \square \quad$ Is pump installed by contractor in section 2 ?

Else installed by pump installer.

b HHSS installer's License ID.

Pump Installer's License No.

Pump Installer's Email Address

Pump Installer's Firm Name

Pump Installer's Firm Address

City: Red Cloud

Pump Installer's Firm Email Address
Pumping Rate $\quad 225$ gallons

\begin{tabular}{|r|r|}
\hline 413312 & \\
\hline 39446 & Pump Installer's Name Mitch A Watson \\
\hline drillerwatson@hotmail.com \\
\hline Watson Well Drilling \\
\hline Roule 1 Box 27 \\
\hline
\end{tabular}

\begin{tabular}{|lllllll|} 
State NE $\quad$ Zip Code & $68970-0000$ & Phone & 402 & $746-3373$ \\
\hline
\end{tabular}

d Drop pipe diameter 3.inches

f Pumping equipment installed $10,24,2005$

h This well will be used to pump less than $50 \mathrm{gpm}$

E measured or estimated

e Length of drop pipe 152.

g Pump Brand

BERKELEY

9 Well Construction Information

$\begin{array}{lllll}\text { a Total well depth } & 164 . & \text { feet. } & \text { b Static Water Level } & 98 . \\ \text { c Pumping Water Level } & \text { d Well construction began: } & \text { f Bore hole diameter in inches. Top } \\ \text { e Well construction completed: } & \text { Geet. }\end{array}$

10 Well Construction (Casing and Screen)

\begin{tabular}{|c|c|c|c|c|c|c|c|c|c|}
\hline Fr Depth & To.Depth & Case Scrn & In Diam & Out Diam & Thickness & Scrn Slot Size & Material & Trade name & crick NOLAD \\
\hline $\begin{array}{r}0 \\
\ldots \quad\end{array}$ & \multicolumn{2}{|c|}{145 casing } & 6.065 & 6.625 & .280 & & PVC & PW & 113237099111 \\
\hline $14 \overline{5}$ & - & screen & 6.065 & 6.625 & .280 & .030 & PVC & JAYCO & 113237099111 \\
\hline 155 & 164 & casing & 6.065 & 6.625 & .280 & & PVC & $\overline{P W}$ & 113237099111 \\
\hline
\end{tabular}

11 Well Construction (Grout and Gravel)

\begin{tabular}{|l|l|l|l|l|}
\hline NOL ID & From Depth & To Depth & GroutGravel & \\
\hline 113237099111997 & 0 & 15 grout & $3 / 8$ BENTONITE CHUNKS & Material \\
113237099111997 & 15 & 164 gravel & $3 / 8$ \& SMALLER & \\
\hline
\end{tabular}

12 Geolog Material Logged

\begin{tabular}{|c|c|c|c|c|c|}
\hline NOL ID & From Depth & \begin{tabular}{|l|l|} 
To Depth & \\
\end{tabular} & Description & 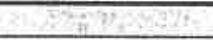 & $x^{\prime}$ \\
\hline 113237099111997 & 0 & 90 TOPSOIL \& CLAY & & & \\
\hline 113237099111997 & 90 & 146 SANDY CLAY & & & \\
\hline 113237099111997 & 146 & 155 MEDIUM SAND \& GRAVEL & & & \\
\hline 113237099111997 & 155 & 156 OCHRE & & & \\
\hline 113237099111997 & 156 & 164 GRAY SHALE & & & \\
\hline
\end{tabular}


Appendix D:

\section{Property Records for the Former CCC/USDA Facility}




\section{MISCELLANEOUS RECORD NO: N}

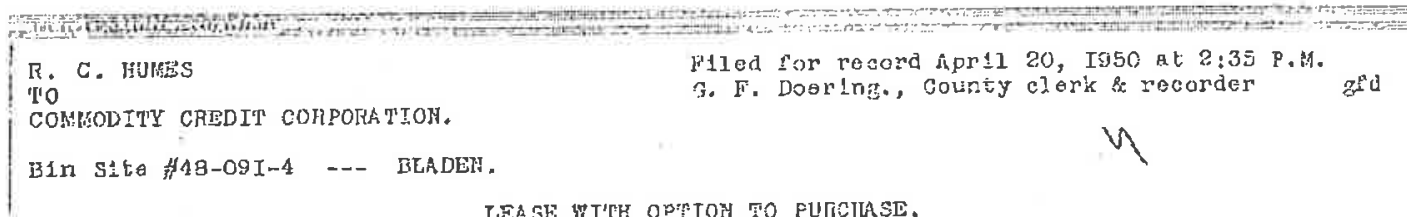

LEAGE HI'H OP:ION TO PUTCILASE.

Tilis LEASE, grede and entered into thla 5 th day of April, igso, by and botwoon R. G. Fumea of 13 ledon, Nebr. Lesaor, end Commolty credit cosporation, Lesgee.

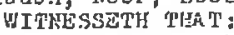

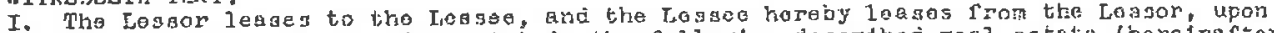

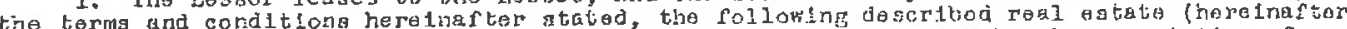
called "property") getuated in tho courty of Hebetor and state of Nobraska, consistinis or called probivision _ - - Town or urogi 320 reot of County Survayor's tot

$$
\begin{aligned}
& \text { Nita of the - - - - of I/4 of Section IP, 'Poznship' } 4 \text {, } \\
& \text { Rango II, }
\end{aligned}
$$

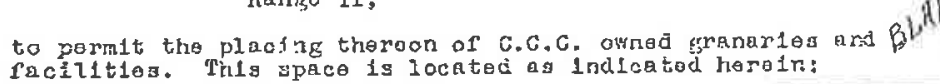

2. The teme of the lease ghall be for a period of ilve Jeara, commencing the 5 th day of April; I050, and ond 1 ng the stin day of Apri1. I955, nith tho ripht of the Leased to the sth day of April, I955, ilitility ror any further rent, terminato sald laago, and liability for any furthot rent, on tho. firet day of any month of any yoar, by ety
days' provious notico in writing to tho Lossor.

3. As ront for sold proparty, the Lesseo shall. pay

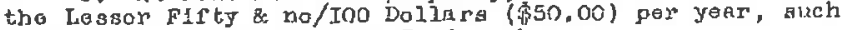
rent to be jayabla Detober I of each Joar.

4. The Toser wermente that he fis the ovnor of the property, has the right to give the

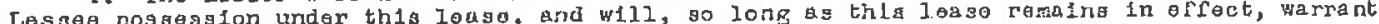
End derond the Legsoo's possasion egrinst any and all poraon whomsoover.

5. The Lessoo shall hava tie right to conatruct or aroct storage structurea or fac1l1t1es on ald proporty ard, at the explration of 9 id leasg or any renewal or oxtenglon thereor

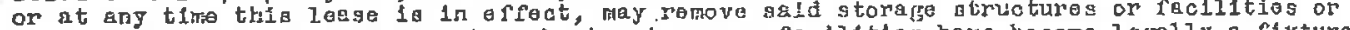
any part thereor, whother or not such structures or facilitios have vecome logally a rixture.

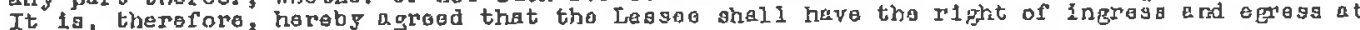
any timo to tho spaco hereir loasod.

6. Phe Lossee shall not asalin this lease nor sublot sald property or any part thereor ul thout the writter consent of tho Les aror.

7. The Lesscr hereby roserves unto itself, and for ltg lesseas, the ripht to cperalie, maintain anc ronow such pipe lines, electric trangmisston 11 nos, telephone linas, telograph Iines, elinal lines and other Paglilties of liko charaoter as may extst upon, under or over th

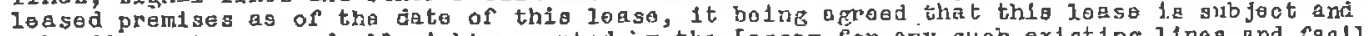
aubcrdinate to any and all righta grantel oy the lessor for ary such oxigting linas and facllit $10 \mathrm{~s}$.

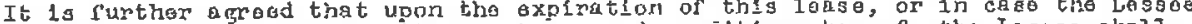
shal in any manner fall to oomply with the toras and conditions horear, the Lesseo shall, shall in any menner las or remeln upon sald premioes ajd sizel remave nil the improvoments forthrith, cease to use or realn upon pleced thereon by the Lessee and restore $B$ ald promisos to stostantisliy the

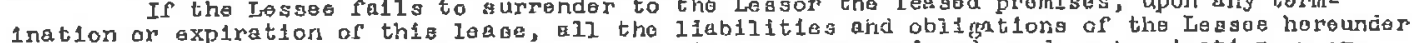

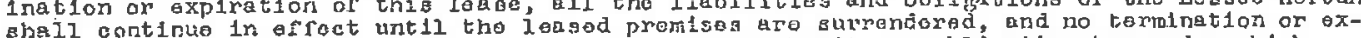

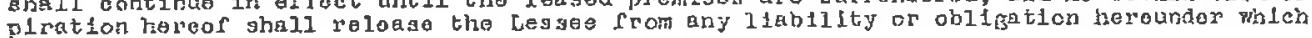
theretorore of therearter may accrue.

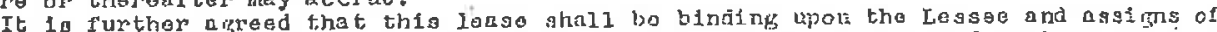

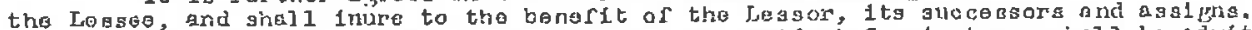

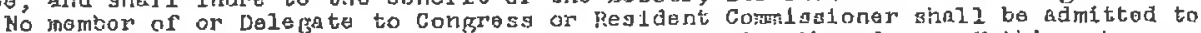
anyr

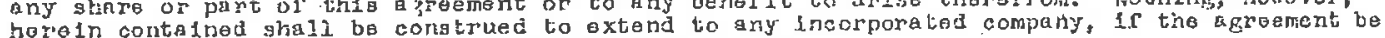
for the gonersi benorit of such corporation or company.

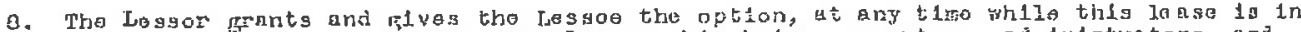
effock, to purchase said property from the losgor, hla helrs, oxecutorg, acisinigtretora, end

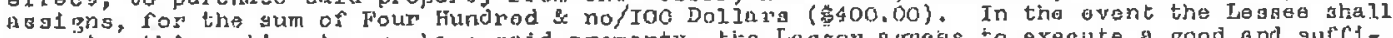

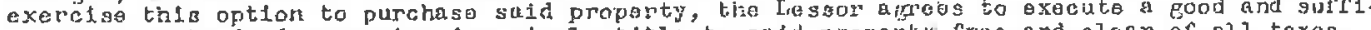
clent warranty deed conveying roe slepie titlo to sala property free and cloar or all taxos, liens, or enaukbrances oxcept for the rollowing and no ctrers: - - - - - - - -

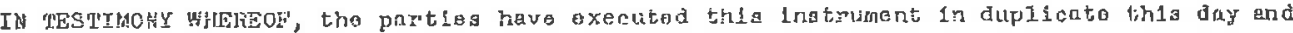
yoar fifist above writter.

/s/ JOHA D. Fingriz., Witnos.

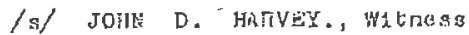

(s) M. B. HUYES., Losaor.

$\mathrm{I} \mathrm{S}_{4} \ldots \ldots \ldots$

13...................

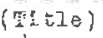

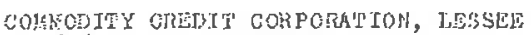
By /a/ PAY D. JOCHASON.

Goritisacting orricor.

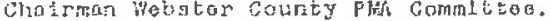

State of Nobraglea

Courtiy of Mabaten

315 
the dato last nforeanid

Hy Comriagion expireg on the I5th dey of bopt. I052.

:YERSTEF COULIY, IJEMRAMK : : HOIARIAL

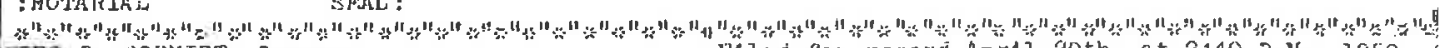
FRED 0. BSGMIDT, IAtsior

$\mathrm{TO}$

COMMODTYY CREDIT COTFOKATINH, LUS IES

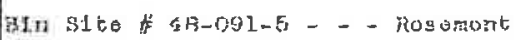

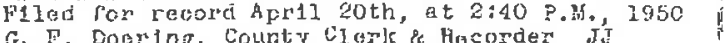

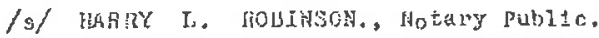

TAEASE WITH OPTIOH TO PHTOTASF

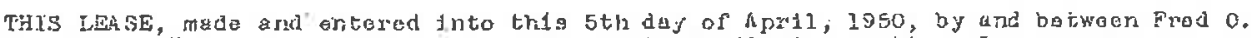

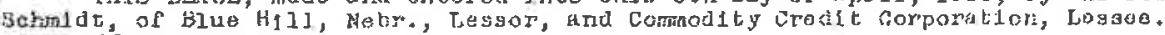

HITASESTH THAT:

1. The Lessor le ases to the Lesseo, and the Lessoo horoby loases fron the Lesacr, upon the torms and conditions haroinertor atutad, tho rollowing daocribed ras estate fherolnafter callod

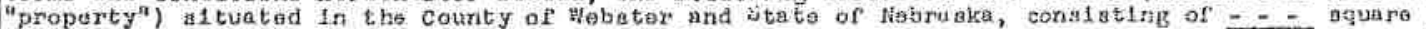

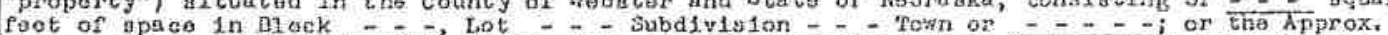

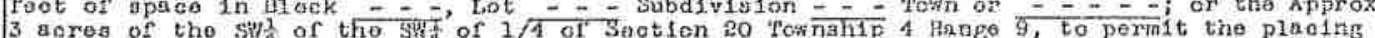

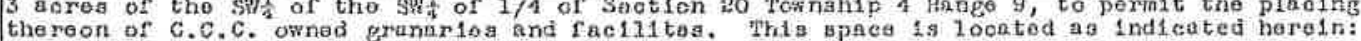

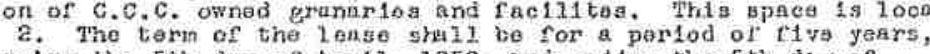

temuneing the 5 th day of Apri1, 1950 , and and ling tho 5 th day of

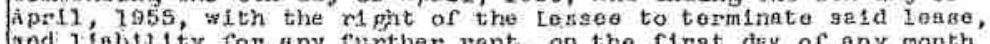
ind liablitity for uny further rant, on the first duy of any month or any yesr, by fiving thirty days' previous notico in writing to tho losar

3. As rent For gald property, the Lessee ahali pay the

Lessor, Fifty and no/100 - - Dollare (\$60.00) per yoar, such rant to be payabio October 1 of each year.

4. The Iessor warranta that he is the ofmer of tho proparty hag the right to give the Lessoe possogsion undor this leaje, and w111, so $10 n g$ as this 1 gea go remalna in offoct, warrant and dofond the Lessoels posagsion aghist any ard al I porsons whorsogver.

5. The Lageoa siali have tha ripht to congtruct or oreot

otoraze structures or recilition on sald property and, at the ox-

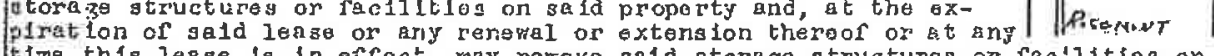
of, whother or not such structuras or fecilltiog havo bacome lo gally a foxture. It is, thorofors.

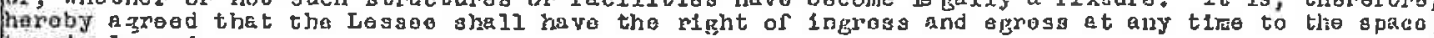
borein loagad.

6. 'The' Lesee shall not assign thls lease nor sublet said property or any pert theroof

without the written consont of tho Itessor.

7. Tho Lessor hereby reservos unto itsolr, and/or its lessess, the r lght to operato, ma1utain and ronow such pipe lines, electric transmisaton lines, telophone lines, telogreph lines, signal Iines and other racilities of liko character as may exist upon, undor or over the leased

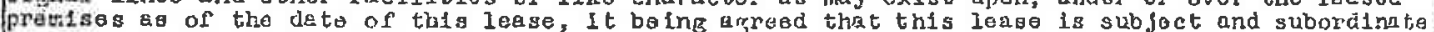
to any and all rights prarited by tho hosor ror any such existing ines and facilitios.

It 18 furthor agreod that upon the explration of this loase, or in case the Lasiea shell $1 \pi$

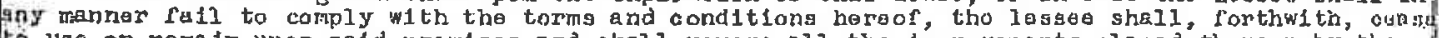

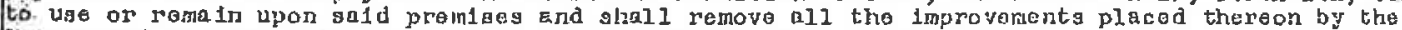
Losace and restore sala premises to subatanatialiy their Cormar ateto.

If the Lesseo rallo to surronder to the jossor the leased premlsos, upon any tormination or explration of this loaes, all tho liabllitieg and ablirations of the Legseo horounder shall conEf nue in errect until the leaged premiges are surrendorod, and no terrination ar expiration hera of shall release the teasea from any liabllity or otli ration lureunder which theretofore or thureaf"tar may acorus.

It 19 nirthor spiread that this lease ohall be binding upon the Loasae and asagus of the Losaes, and shall Inuro to tho bonelit of tho Lisasor, 1 ta sucesasors and asalgna.

No menbar of or Dalepate to Conpress or Resldunt Cominisaloner shall be acinitited to any Bhare or pert of this agregment or to any banefít to ar1 so therofrom. Nothing, horevir, heroin contalned sha 11 be conatrued to extend to nny inoorporuted conpary, if the aproement bo for the teraral benerit of such ocroporation or conpany.

8. Tho Leasor grants and grives the Eossoo tho option, at any time while this $\lambda$ euse is in efrect, to purchmeo anid pronarty from the fesaor, his hairs, executors, adainistratora, and assigns, for the sum of Pour Hundred and no/ 100 - - Dolises (\$400.00). In the ovent tho Lassee phall exarciso this option to purchasu said properby, the Losaor agrees to exeauto a good and

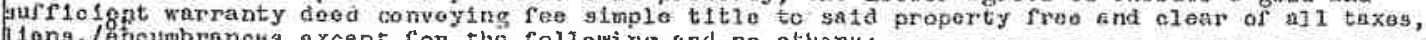

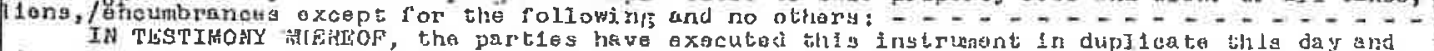
yiner riret above witton.

S) JOHA D. HARVEY.

W.tnese.

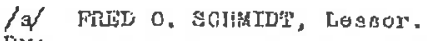

Sif JOHN D. HA ITVEY.

witnoss.

Iy: $\ldots$

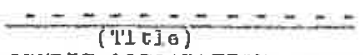

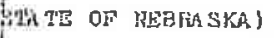

COUNTY OT WEBSTWRis

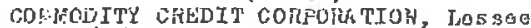

B): /af las D. JOHASON.

Contracines orficor,

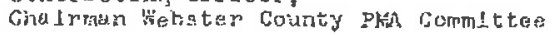

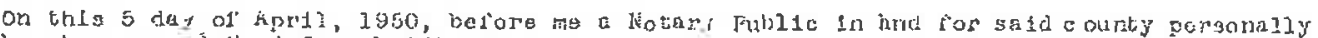

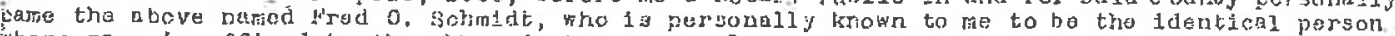

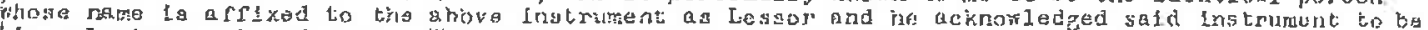

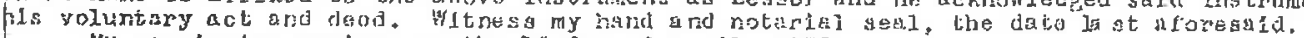

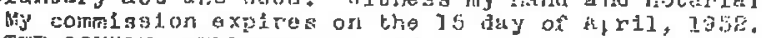

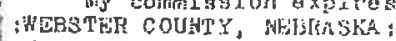
: VIOTARTL
SERT:

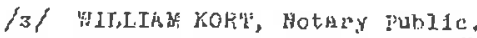

"

Appendix D, page 3 of 15 
Howhow appurtenances thereto and related facllities, on, over and across the following described lands,
situate in hiebster County. State of Mebraska, to wit:

A tract of land lying in the N $\frac{1}{2}$ wis of Section 33, Township 2 North,

Range I2 Hast of the Sixth Principal Heridian, containing 29.21 acres, more or less, lying with in the closed course more particularly described as follows:

Beginning at Point $A$, which point bears $S 90^{\circ} I 4^{\circ} 30^{\prime \prime}$ W a distance

of 318.1 foet from the northwest corner of Section 33 and proceeding

thence N $84{ }^{\circ} 55^{\prime}, 00^{\prime \prime}$ E 757.0 feet to point B;

thence $356^{\circ} 58^{\prime} \mathrm{DO}$ " $\mathrm{E} \quad 620.0$ feat to point C;

thence $S .33^{\circ} 02^{\prime} \mathrm{OO}^{\prime \prime} \mathrm{W} \quad \mathrm{I}$ (50.0 feet to point $\mathrm{D}_{\text {; }}$

thence $356^{\circ} 58^{\circ}, 00^{\mathrm{N}} \mathrm{E} \quad 156.0$ feet to point E;

thence $S 84^{\circ} 43^{\circ} 00^{\prime \prime} E \quad 907.1$ feet to point $F$;

thence N $67^{\circ} 02^{\circ} 00^{n} E \quad 463.0$ feet to point $G_{;}$;

thence $800^{\circ} 42^{\prime} \mathrm{OO}$ " W 240.2 feet to point H;

thence $S 67^{\circ} 02,00^{\prime \prime}$ W 629.1 feet to point I;

thence $184^{\circ} 43^{\circ} 00^{\prime \prime} W \quad 445.1$ feet to point J;

thence $\mathrm{N} 56^{\circ} 58^{\prime} 00^{\prime \prime} \mathrm{W} \quad 600.0$ feet to point $\mathrm{K}$;

therce $S 33^{\circ} 02^{\prime} 00^{\prime \prime} W$ I 142.3 feet to point $L$;

thence If $56^{\circ} 58^{\prime} 00^{\prime \prime}$ W 670.0 feet to point $M$ :

thence $S 65^{\circ} 42^{\circ} 00^{\prime \prime} W^{\prime} 534.0$ feet to point $\mathrm{N}$ :

thence N $00^{\circ} \mathrm{I}^{\prime} 30^{\prime \prime} \mathrm{E} \quad 475.9$ feet to point of beginning.

(\$2.75 revenue stamps affixed)

2. The grant of easevent herein contained shall fnclude the right of the United States, Its agents, contractora, or assicmees, to enter upon safd premisos to survey, cleax and remove objects interfering with the use of eaid lands for the purposes haretnabove sentioned. Vencior reserves thr right to cultivate, use and oecupy sald pronises for any purpose consistant with the xights and orivilegos above granted, and which wtIl not interfere with ar obatruet the conetruction, operation and mintenarce of the proposed Franklin Cana1 and rolated foclititiss. In case of prormantent abandotnent of gaid right-of-way, the title and interest here in granted shall end, couse and determine.

3. Vendor is to be prid damages for all crops growing upon tho landis horoin desteribed if destroyed by Government construction forces during tho conatruction of tho proposed facilitiea. The atmount of danagea 13 to bi vetermined by a Buroau appra1sal board by an appraisal mate on or about tho clate destruotion occurs. Baid amount shall not exceed $\$ 80.00$ an acre.

1. The grant of ensemont herein contalned is subject to any coal or mineral rights. reserved to or outatanding in third purties as of the date of this contract, and to any existing rights -of -way in favor of the publie or third partioa for roads, railroads, telephone lines,

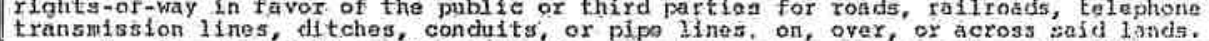

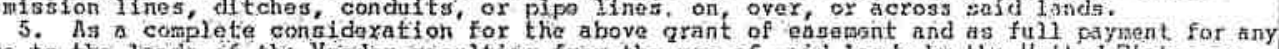
damage to the landa of the Vondor resulting from the use of gaid lands by the United atates as grovidedi in this contract, the United States agrees to pay the Vendor the sun of Two Thousand One fundred Thirty-three and $40 / 100$ Dollars $(32,133.10)$, excopt as specifteally provided in Article 3 hareof.

6. If the Secretary of the Intertor datermires that the title should be acpuired by the United States by judicial proceduro, either to procure a oafa title or to obtain titio nore quick. ly or for any other reason, then the arard to be made fox the interest acquired in said lands in said proceedings shall be the some amount as the purchase price herein provided.

7. No Member of ox Dalegatie to Congress or Rasident Conmilssioner shall be adalttecl to any share or part of this contract or to any besafit that may arise therefrota, but this restriction shall not be construed to extend to thia contract if mada with a corporation or company for its

genaral benefit. IN WTITESS WHEREOF, the parties hereto have caused this agreonent to be exexuted the day and year first above written.

THE UNTTED STATES OF AMERICA

By lol H. E. ROBINSON.

Title Projects Hanager.
Ts IDR RICHARDSON.

it Ida Richardson.

CERTIFICATE OF ACKNOHLEUMEHT

STATE OF NEBRASKA ]

COUNTY OF LANCRSTER) 50 . I, E. Chet Swearengen, a Notary Public in and $f$ or scid county in the State aforesaid, do hereby certlfy that Ida Richardson, a widow scribed to the foregoing 1ngtrument, appeared bafore me this day in persor and acknowledged that she signed, sealed, and delivered said instrument of writing as her free and valuntary act, for the useg and purposes therein set forth.

I : LANCASTER COUNTY, NEERASKA: :NOTARIAL

Glven under my hand and official seal th15 29th day of June, I954.

SEAL: /5/ E. CHET SWEAREHGEN., Signature.
My comisy Public. Titie
My explreg Aug. 4, I957.
R. C. HUVitES, LOS5OT

to

COAMODITY CREDIT CFN.LESSE.

\section{U. 3. DEPARTIAENT OF AGRICULTUKE \\ CORE STRBILTJRTIOH WN CONSERVATION}

THIS LESSE, made and entered into this 20 day of July. I 954 by and between R. C. Hunes of

Bladen, Nebr. Lessor, and Comodity Credit Corporation, tessee.

I. The Lessor leases to the Lesaee, and the Lassee hereby leases ftord the Lessor, ypon the

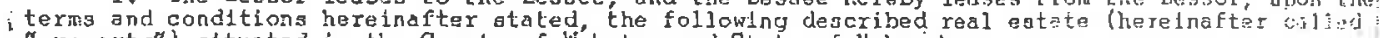

"property") situated in the County of Webster and state of Nebraika: 

Lessee, may, however, sublet the structurea on the premises leased hereunder, or any one or more of them for the tern of the lease or any part thereof upan such terms and conditiona as Lessee way wish to so sublet.

7. The lessee, if required by the Lessor, shall, upon the expiration of this lease, or ranewal thereof, restore the oremises to the same condition as that axisting at the titne of entering upon the save under this lease, reasonahle and ordinary wear and tear and damages by the elements or by circumstances over which the Lessee has no control excepted: Provided, however. that if the Lessor requires such rostoration, the Lessor shall qive written notice thereof to the Lessee 30 days before the termination of the lease.

8. The Lessor grants and gives the Lessee the option as a consideration of this lease and for the further consideration of one dollar, the receipt of which is hereby acknowledged, to renew said lease for a period of $S$ years from the Lessor, his heirs, executors, adrinistrators, and

assigns, for the sum of Fifty \& Nolino Dollara $(\$ 50.00)$ per year.
9. As a consideration of this lesse and for the further cons

receipt of which is hereby any time while any time while this lease is in effect, to purchase said property from the Lessor, his heira, executars, adininistrators, and assigns, for the sum of Four fiundred Dollars $(\$ 400,00)$. $I_{n}$ the ish at his own shall exercigo this option to purchaso said property, the Lossor agrees to furnish at his own expense an abstract of title, certificate of title, or other avidence of title satisfactory to $\mathrm{CCC}$ and to executa a good and sufficient warranty deed conveying fee aimple title
to anid property free and olear of ali taxes, lions, or encumberances except for the following, and no others.

10. In the event any Increased tax assessment is rade agalngt the Lessor or the property by virtue of the erection of storage structures and facilities thereon by the Leasee, the Lessor agrees to cooperate fully in any oonteat of ouch increased assessment which the Lessee foels should bo made. The Leasee agrees that the rental hereunder shall be adjusted upward by the amount of any such increased tax assessment which the Lessor and Lesseg mitually boreo to bo pro.

per or which is determined to be legally valid in court proceodings.

any share or part of this lease or purchase or to any benefit thas provision shall not be for its general benefit. I2. The lessorit.

leasg upon The Lessor warrants that he has not eaployed any person to solicit of secure this lease upon any agreement for a comaisaion, percentage, brolerage, or contingent fee and that no
ruch consideration or payment has been or will be made. Breach of this warranty shall give cCC
the right to annul the right to annul the lease, or, in 1 ts discretion, to deduct from the rental or purchase price the amount of juch coamision, percentage, brokexage, or contingent foes. This warxanty shall not apoly to comissions payable by the Lessor if the lease is secured or made through a bonafide agent maintained by the Lessor for the purpose of leasing or selling his property.

(Seal) /s/ R. C. HUMES., Lessor. COMHODITY CREDTT CORPORATION. LESSEE.

By $|s|$ JOHiN D. HRRVEY., Chalrman, Notary Public" : WEBSTER COUNTY, NEBRASKA : HOThRY PUJLIC SEAL

ESTATE OF ALEERT U. KALEY, DEC'D TO HOWARD B. KALEY.
Filed for record July 24th, I954 at ID:40 A, M. A G.F. Doering, County Clerk \& Recorder.

FINAI DECREE

IH THE COUNTY COIRT OE WEBSTER COUHTY, HERRASKA.

IN THE MATTER OF THE ESTATE OF AlDeTt U. KalOY, DECEASED.

At a session of the County Court held on the 24 th day of July, I954, there being present, harry M. Barrowa, County Judge of said county, and Howard B. Kaley, Adra, and Howard S. Foe, his attorney.

This day having been assigned by order of this court, for hearing on the netition and final report of the above named legal representative of said estate, praying, among other thinos, for the examination and al lowance of the final report of such representative herotofore flled, and rar final settlement of said acount and pert, and for a digcharge of said representative. 
$\operatorname{rrom}$

R. C. \& NOIA HUMES, husb \& wf รo

ARTYUR B. \& BTELA MAY MOREY, h!心b \& wf

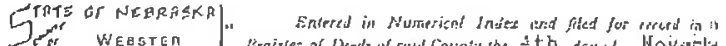

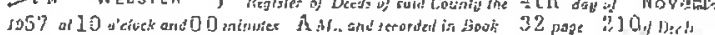

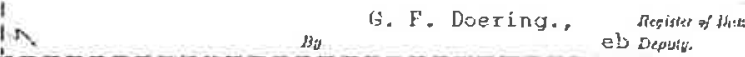

WAIAANTY DEED-VESTING EATIRE TITLE IN SURTVOT.

KNOW ALL MEN BY THESE PRESENTS, That We, R. C. Huses and Nora timets, husbind and wife, each in his \& her own right.

\begin{abstract}
in considerafion of - _ _ One \& $00 / 100$
\end{abstract}
in hand paid, do hereby grant, bargain, sell, convely ond confirn unto Arthur B. Florey and Stella ihay tho rey, his band and wife

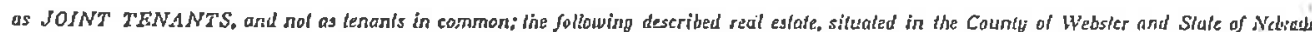
to-wil: $\cdots$

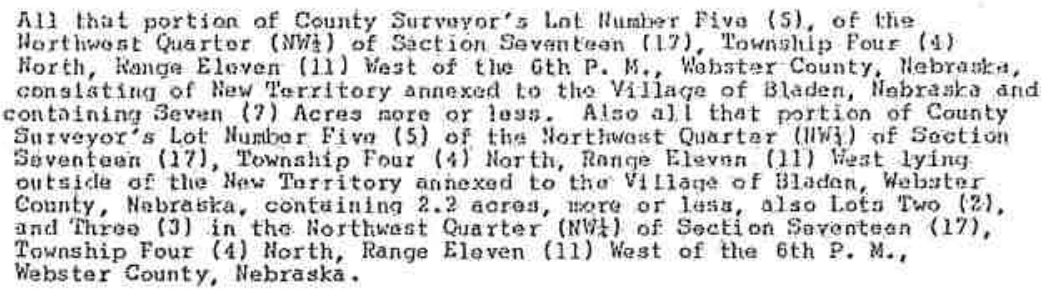

(\$1.65 revenue stamps affixed)

fogether with all the tenements, heredifoments and appupferanecs fo the same belonging, and all the estate, fille, dower, right of homestcad, cleim or dersy wharscever of the said grantors of, in or to the same, or any part thereaf; surbjest to _ . . . . . . . . . . . . .

IT BEJNG THE INTENTION OF ALL PARTIES HERETO THAT IN THE EVTNT OF TBE DEATH OF EITHER Ü SAID GRANTEES, THE ENTIRE FEE SIMPLE TITLE TO THE REAL ESTATE DESCRIBED HEREIN SHALL VEST Z TBE SURVIVING GRANTEE.

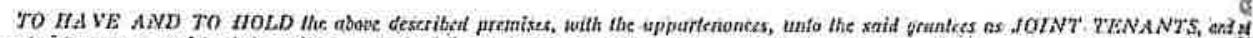

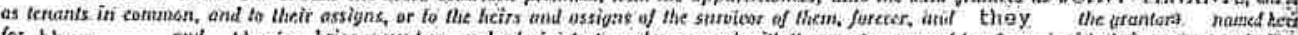

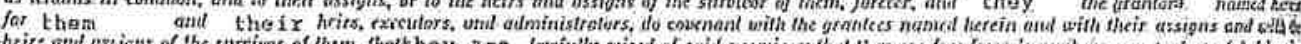

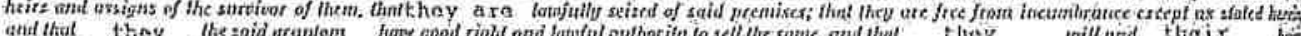

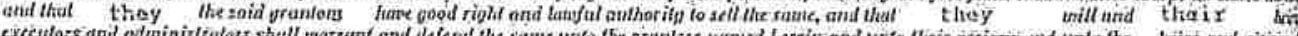

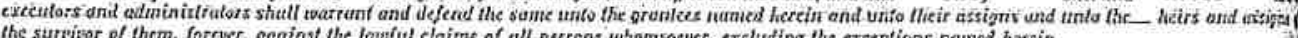
the sumisor of them, forcwer, egainat the lawfut claims of all persons whomsocute, exeluding the erceptions named hetein.

of IN WITNESS WHEREOF We hacehereuniost our harids this loth

May in preserice of $\quad$ A. D. 1957.

/s/ O. L. LIIIDGREN.

Is/ R. C. MLMES.

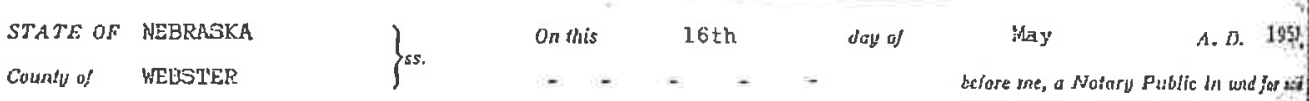

County. personglty came the above named R. C. Humes and Hora Humes, Husband and Wife,

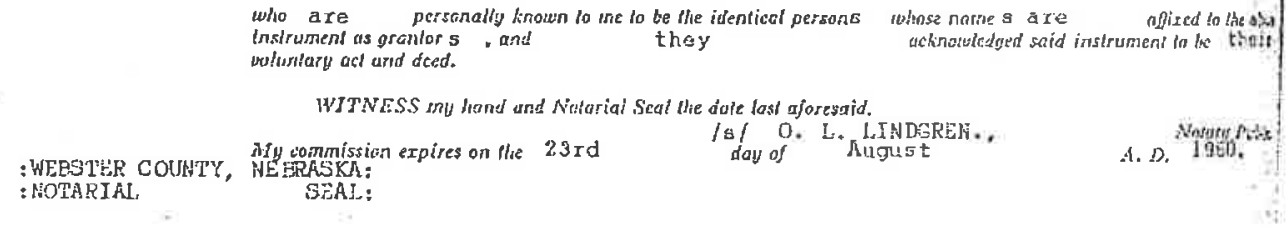




\section{DKSE $/ 2750$}

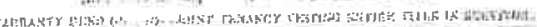

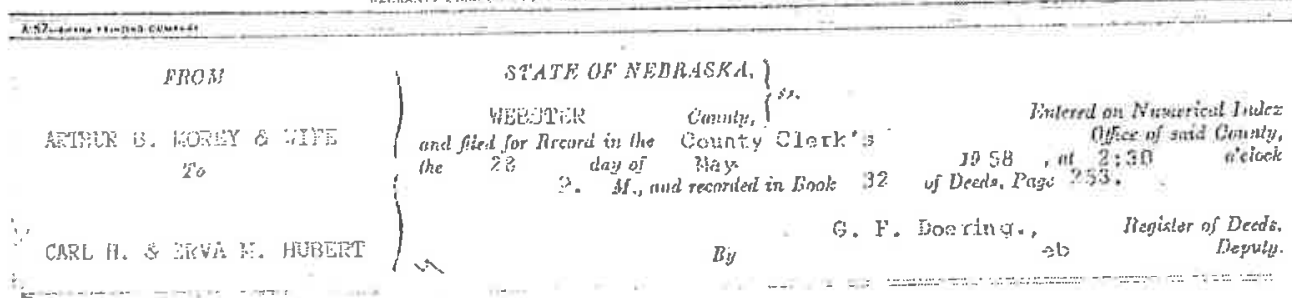

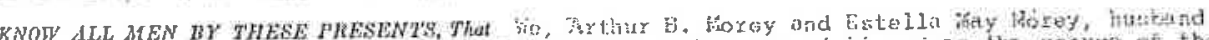
(the spotion of the

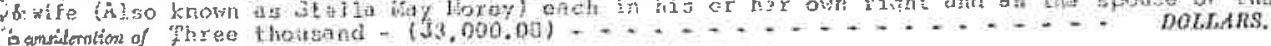

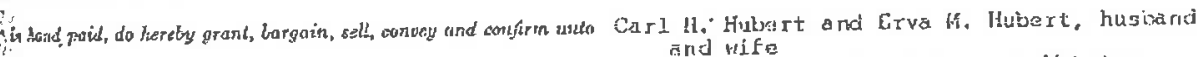

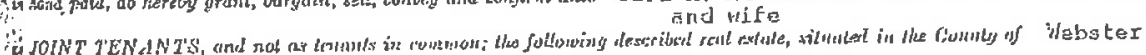

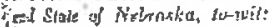

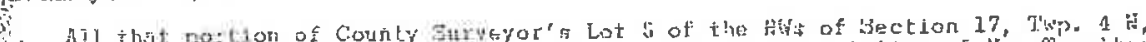

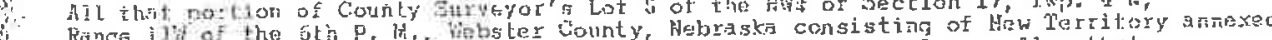

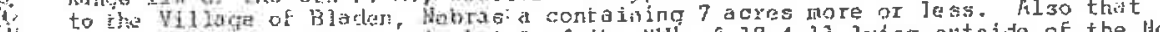
Fortion of County Burreyor's Lot 5 of the Hit of $17-4-21$ lying olatside of the Areb Terrtiory anexed to the i. Hest of the 6th F. H., Viester Conty, Hebrasku.

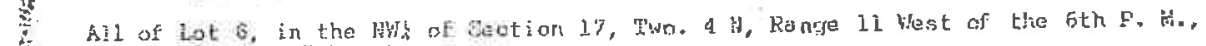
Hebster County, Hebrosita.

\{\$3.30 revenus gtiuns a $\mathrm{f}$ it $\mathrm{ixed}$ )

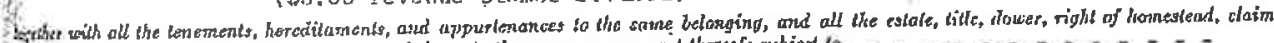
ice der

3

2

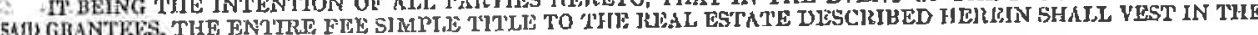
STRVIVING GMANII:

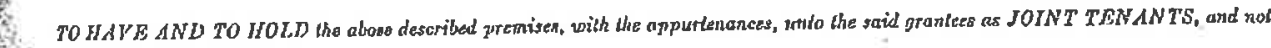

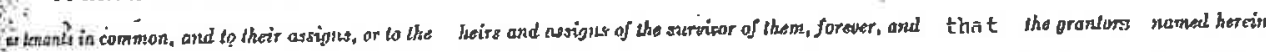

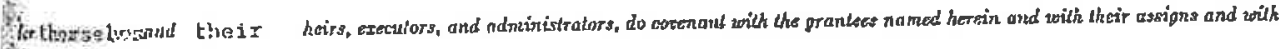

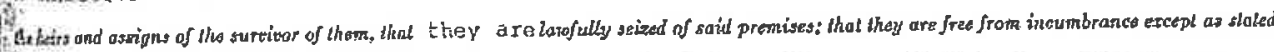

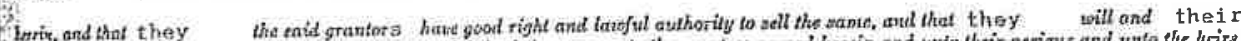

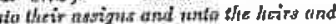

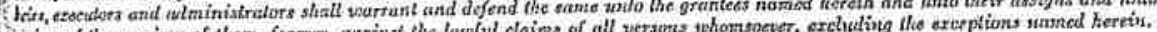

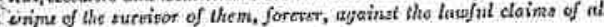

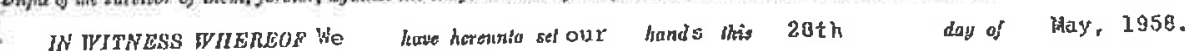
c.soxso

In Presenec of

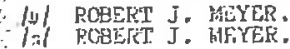

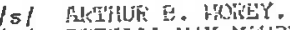

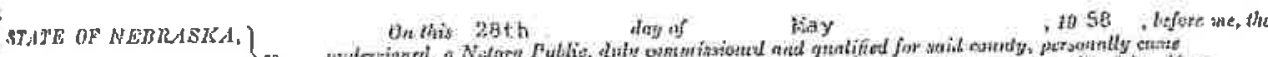

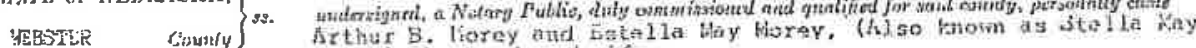 horey ). huetwind and wi fo

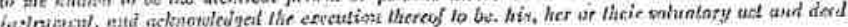

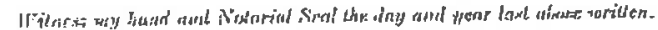

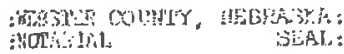

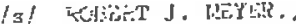

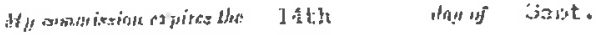
STITE OF NERKAISKA.
(ui bis
dogy of
, 1!) Mriore nis, the
rouniy

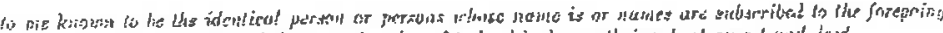

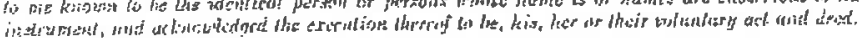

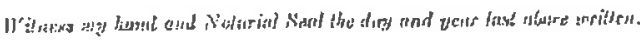




\section{P564}

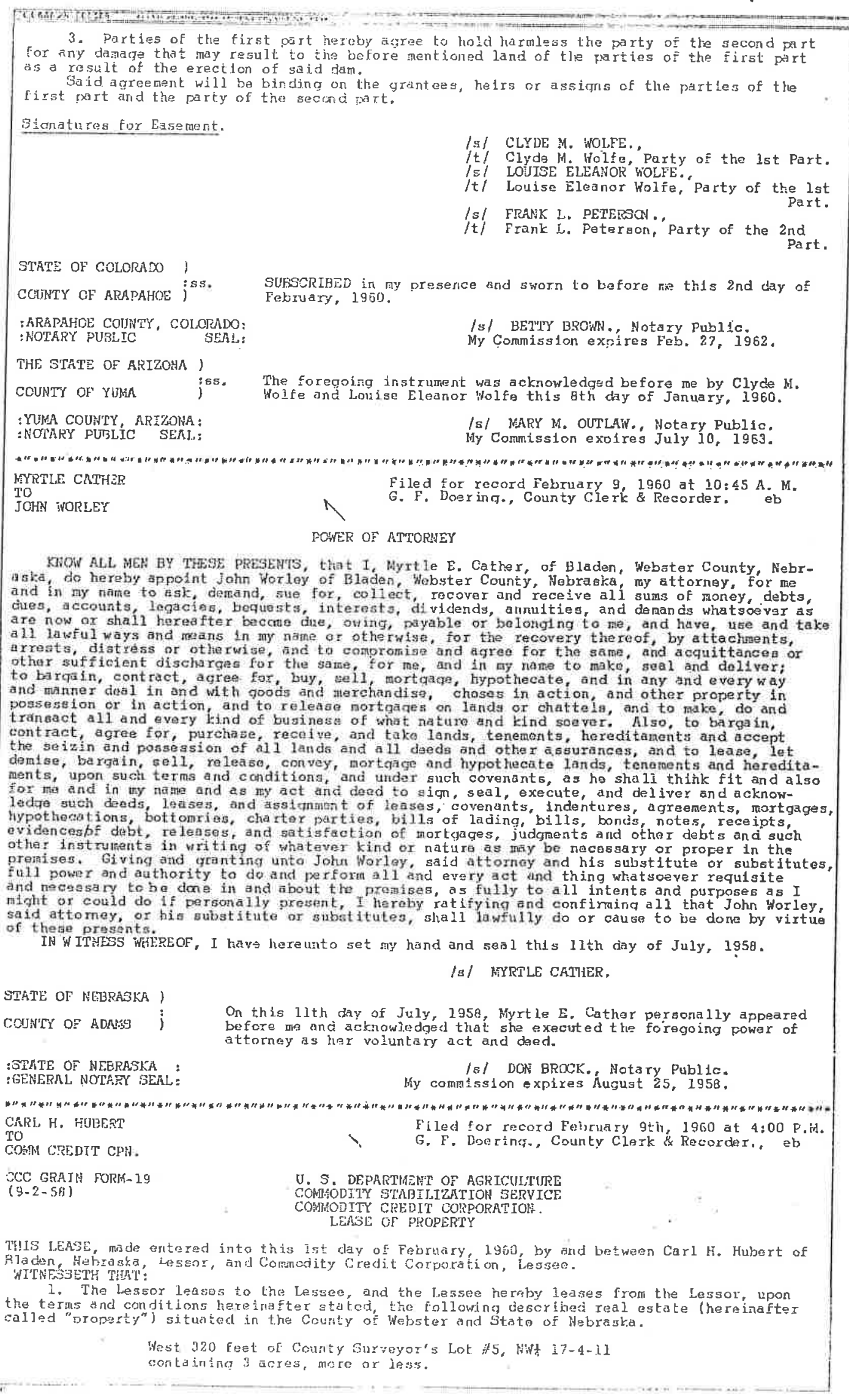




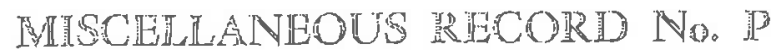

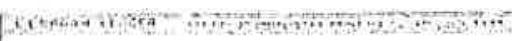

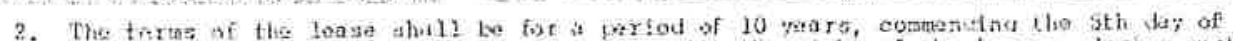

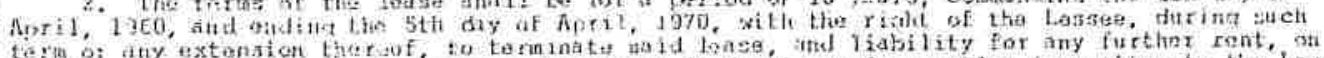

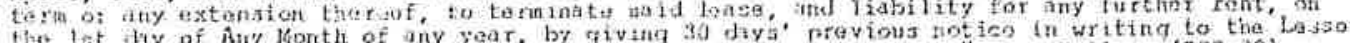

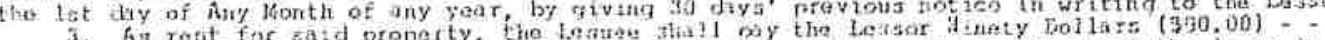

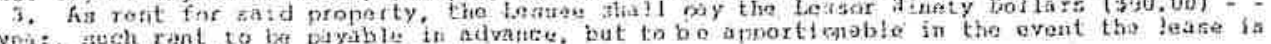

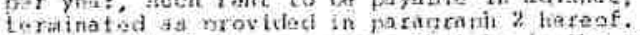

4. The Letson warrants that he is the owner of tha proparty, has the $r$ ight to aiviz the

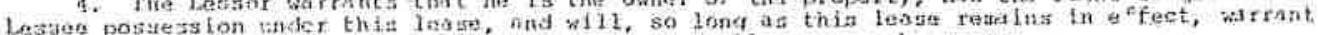
and distend the Lassep's fospeation acal inzt any and all persons whomsonver.

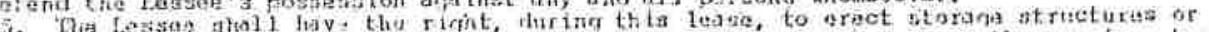

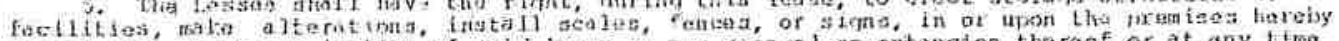

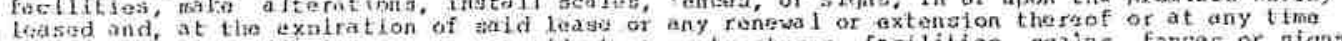

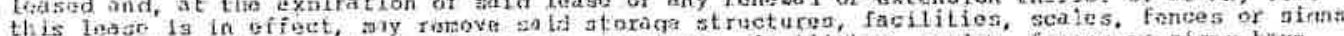
or or any paxt harear, det

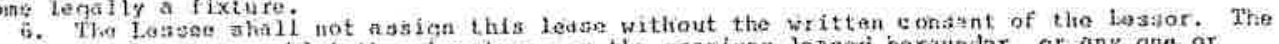

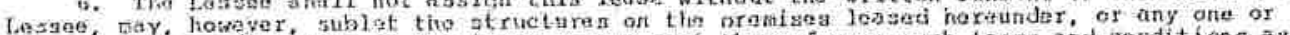
cessee for. Lessee may wish to so sublet.

7. The Lessee, if required by the Lessor, shall, upon the exoiration of this lease, restore the premises to the tane condition as that existing at the $t 1$ me of entering upon the game under this lesse, reasonable and ordinary wear and tear and dimages by the elements or by circumstances over which the lessee has na control excepted: provided, however. That if the lessor zequires such reatoration, the Lessor shall give written notice the reof to tho Lassee 30 days before the ternination of the Lease.

8. The Lassor qrants and qives the Lessee the option as a consideration of this lease and for the further consideration of one dollar, the receipt of which is heroby acknowledged, to renew said laase for a period of $\$$ years from the Lessor, hia helrs, executorb, administrators, and assitms, for the aun of Hinety Dollars $(\$ 90.00)$ per year.

9. As a consideration of this leaee and for the further consideration of one dollar, the receipt of whioh is hereby acknowledged, the Legsor grants and gives the Lessee the option, at any time while this lease is in effect, to purchase said proparty frosa the lassor, his heirs, executors, acialnistrators, and asBigns, for the sum of Appraisal hothod-Dollars (12- - . . axe shall exercise trils option to purchasa said property other ovidence to furnish at his awn expense an abstract of title, certificate of title, or other ovidence of title satisfactory to CCC and to exacute a good and aufficient warranty deed convey ing foe the simrile title to said property free and clear af all taxes, liens, or encumbrances except for the following, and no others. The sum to ba deterinined by three persons, one to be selected by the lessor, one to be seleoted by the lessee, and tha third parson to be selected by the property by irtue of the eroction of storage struatures and facilities thereon by the Lessee, the Lassor sgrees to cooperate fully in any contest of such increased a ssessment which the Lassee faels should be made. The Lessee agrees that the rental hereunder shall be adjusted upward by the anount of any such increased tax assesement which the lessor and lessee mutually agree to be proper or which $1 \mathrm{~s}$ dotermined to be legally valid in court proceedings.

11. Ho Membar of or Delegate to Congress or Resident Consis ssioner, shall be admitted to any share or part of this lease ox purchase or to any benefit that nay arise theryfrom, but this provision shall not be construed to extend to this lease or purchase if made with a corporation for its general benefit.

12. The Logeor warxantu that he has not employed any person to solicit or secure this lease upon any agreentent for a comisision, pexcentage, brokerage, or cont lgent fee and that no such consideration or payment has been or will be made. Breach of this warranty shall give CCC the right to annul the lease, or, in 1 ts discretion, to duduct $f$ ros the rental or purchase price the ameunt of such comianision, percentage, brokerage, or contigant fees. This warxanty shall not apoly to conmissions payble by the Lessor if the la leas aecurading his property. a bona-fide agent. maintained by the Lessor for the purpose of leasing or salling his

(SGA1) /s/ CARL H, LURERT, LESSOR COAGODITY CREDIT CORPORATION, LESSEE

(Sea1) (s) ERVA H. HUUEET, IESSOR By $|s|$ RALPF PORTENIER. Chairman,

STATE OF HEBRASKA )

COUNTY OF WEBSTER ;

: HEBSTER COUNTY, REBEASKA

: VHEUSTER COUHTT, HEBEASIA

Subscribed to by me this 3rd dyy of Febr., 1960.

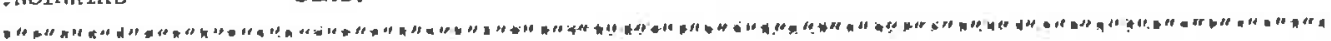

B. iN, EUSS

COHA CKEDIT CPN

1. Filed for record February 9th, 1960 at 4:05 P. M. EXTENSIOA OF LEASE

"THIS EXTENSION OP LEASE, ande and entered into this 1st day of February, 1960, by and between if. y. Euss, hare inafter called lessor, and Commodity Credit Corporation, hereinafter called Lessee.

WTTHESSETH

WHEPEg the parties hereto haye heretofore entered into a certain leaso dated 30th flucust, 1959, where in the Lessor leased to the Lessee tha following described property:

Träet i in $3 \dot{1} \frac{1}{4} 4-4-10$

for a terlli ending October 1, 1950, and

WISREns, it is desired hy the parties hereto to extensi tha said lease for an additicnal terat under the sane termis and onditions:

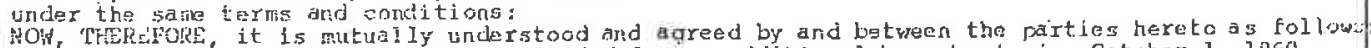
(1) The sald lease is horeby extended for an additional term beginning October 1, 1.960. and ending cotober 1,1970 .

(2) Lessors qrant and qive to tha Lesgee the option of further renewal of the lease for an additional period of five (5) years ending october.1,1375, under the same tering and conditions of the leare as extended herein provided the Lassee gives the Lessors written not.ice to renew at least thirły $(30)$ days prior to the tire tire iease, as extencled, 


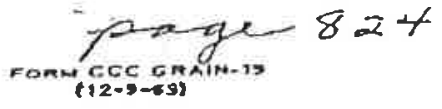

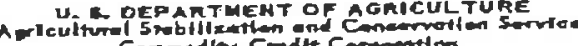 \\ Comorodiry Crodit Compond on}

THIS I.EASE, made and eaterod fo to this

$3 x d$ dny of Marcl $19+69$, by and beiween Carl H. Iivbert and $z r v a$. Hubert or Dladen, Nebxaska

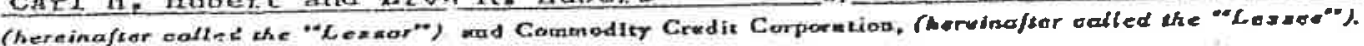
WITNE:SSETR THAT:

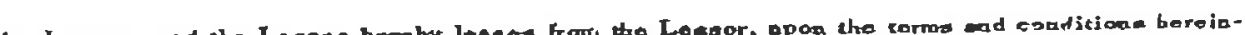

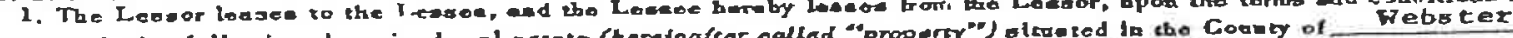

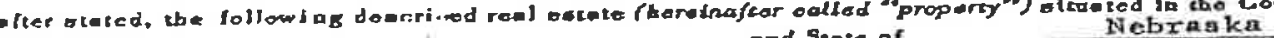

(Entor hora a completo logel dese-iption of the eder)

Hest 320 reet of county surogox's Iot 5 , NW $17-4-11$

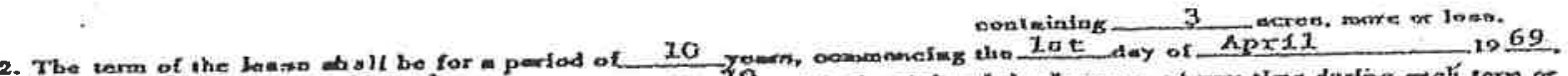

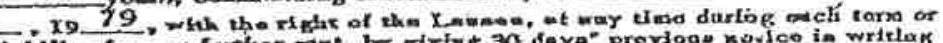
and eadiag khe to sho Lenutor.

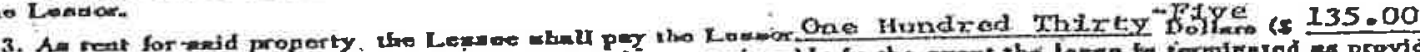

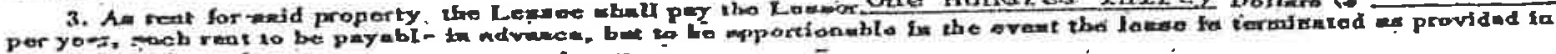

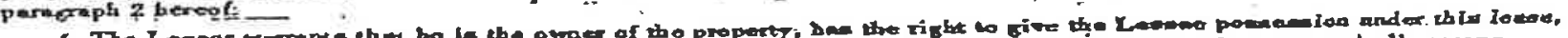

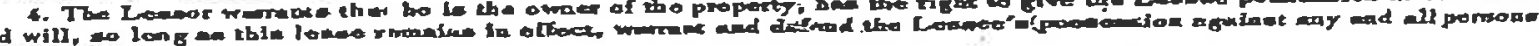

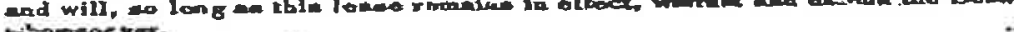

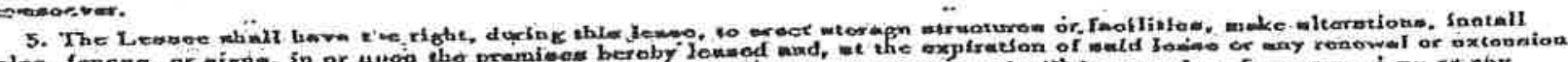

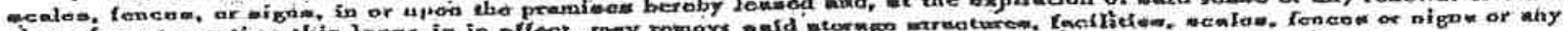

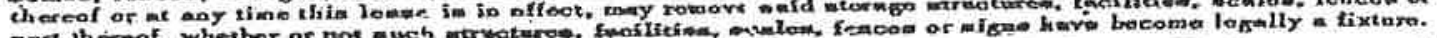

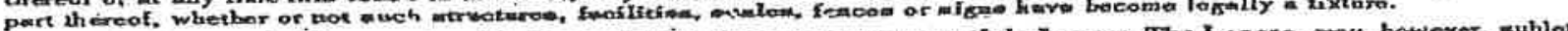

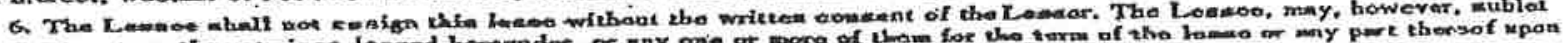

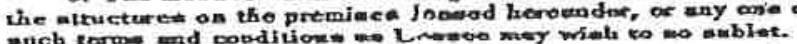

7.

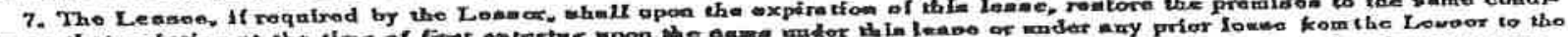

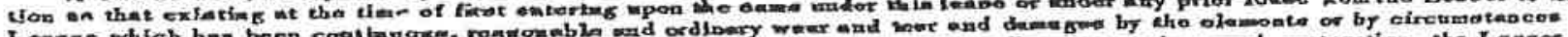

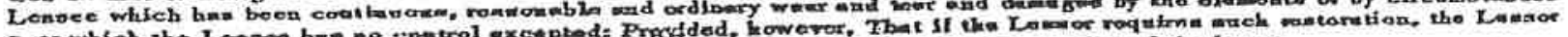

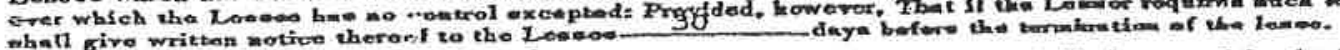

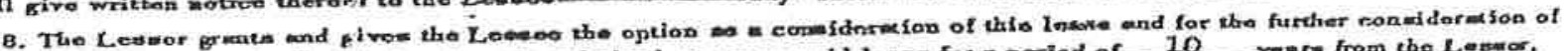

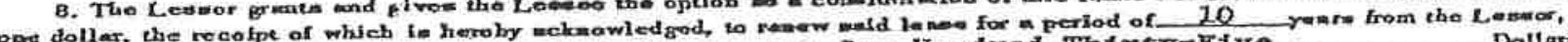

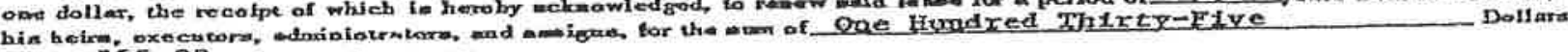

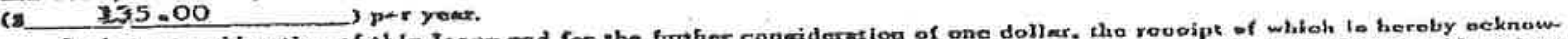

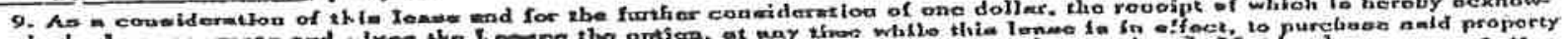

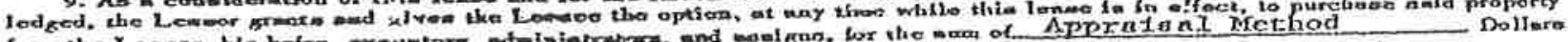

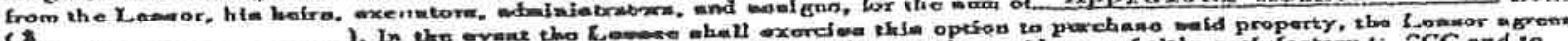

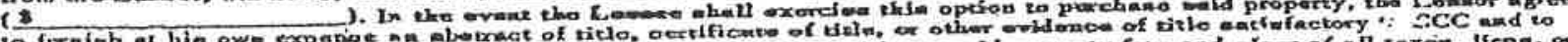

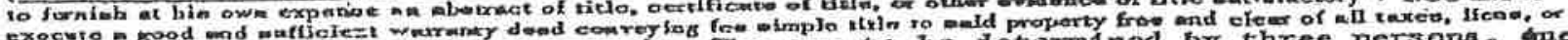

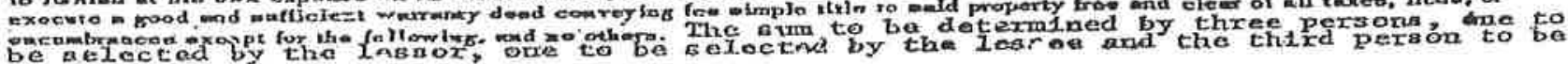
selected by the fixat twa- 


\section{romengeres 825}

10.

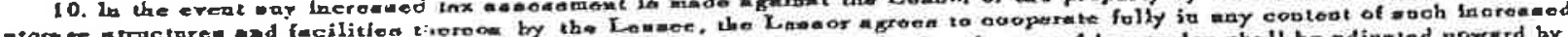

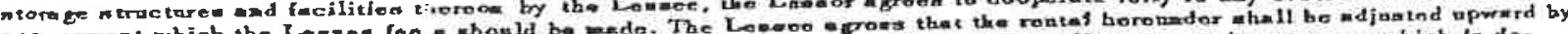

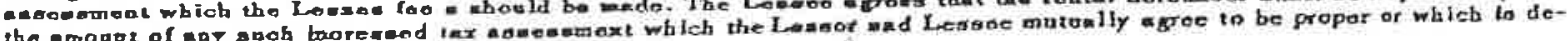

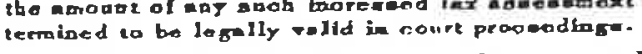

$\because-4$ p. Hor or

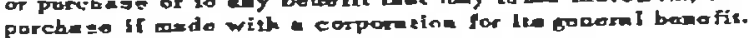

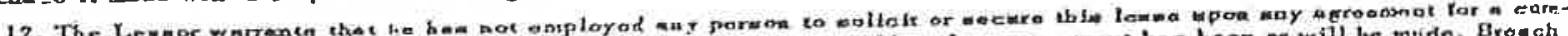

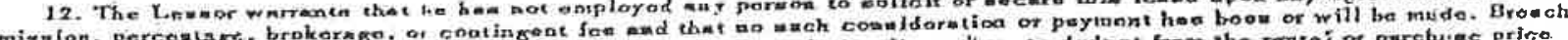

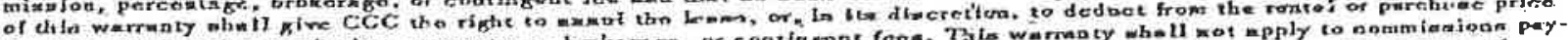

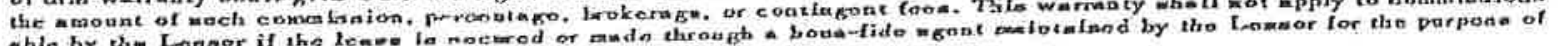
lementak or melliag bie property.

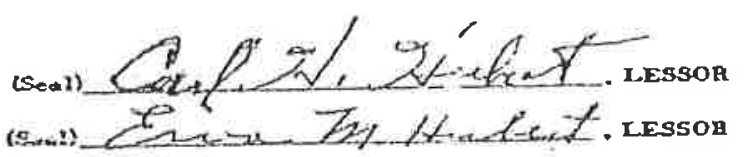
MTTESS

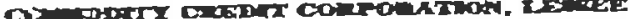

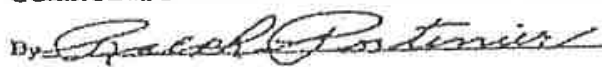

Chelnuen. Hebster ASC Comey Conon I:twe Comeracting Oftices

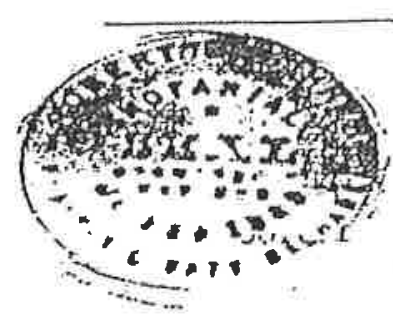

State oE Mobraba

county if Tebster

- On thio 20-n day of March

1969 . Nefore me a Fotary Public in and for a ald county $M$. Hubert pexionalif enma tho above-nomed Caxl H. Hubext and axve

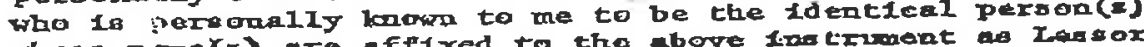
whose n-o $(x)$ aro affixed to tho above 1a to thelr voluntary act

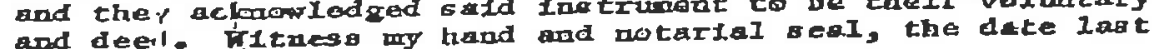
afordent.d. . $19.65^{14 y}$

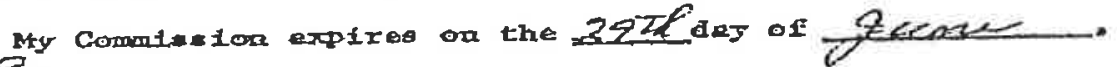

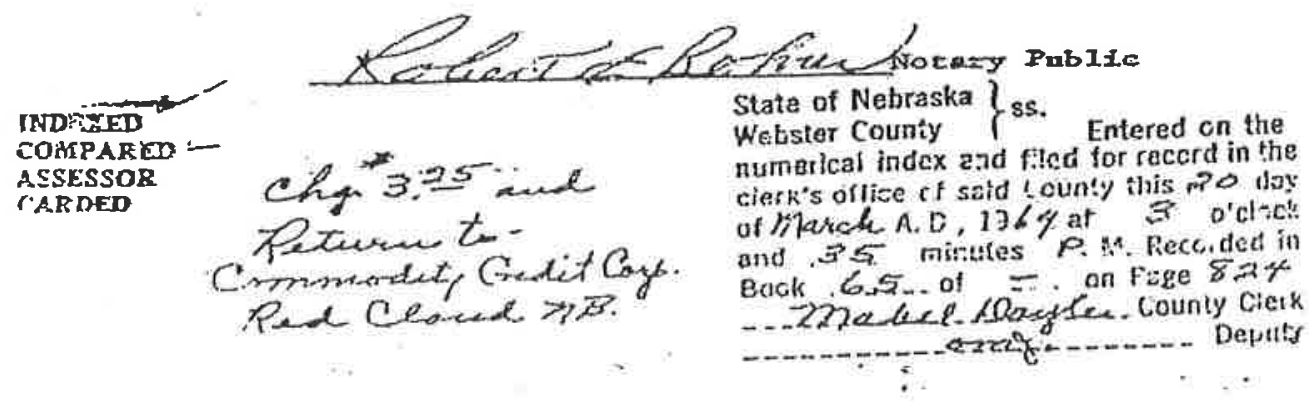




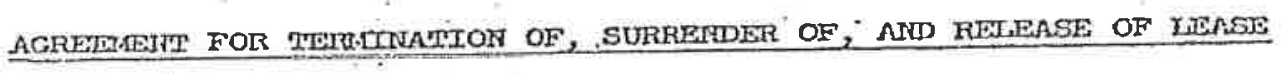

This airreement by end botwoen Carl H. Hubert and Erva M. Hubert, hereinarter callea "Iessor", and ccumodity Cradt corporation, horelnarter called "CCC", Is made irth reppect to a lease (hereinatter cclled "the lease") heretorore entered Into botwean Lessox and CCC, whereby Lessox learea to CCC real estace situated in the county of webster , liebrcslix, descrtbed ns follows:

West 320 Feet of county surveyox's Lot 15 , NWw $17-4-11$

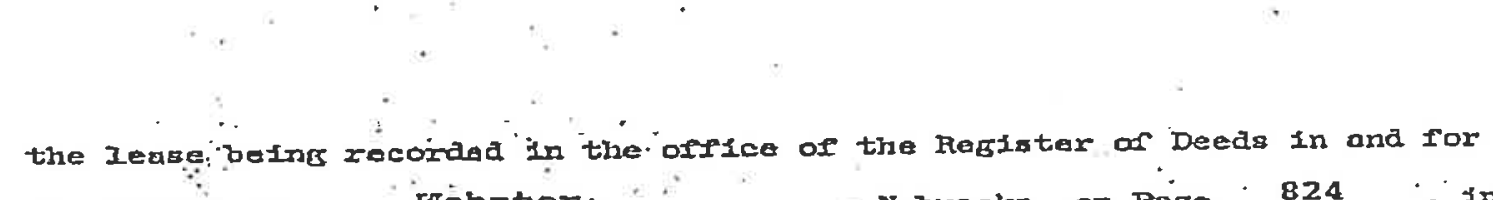

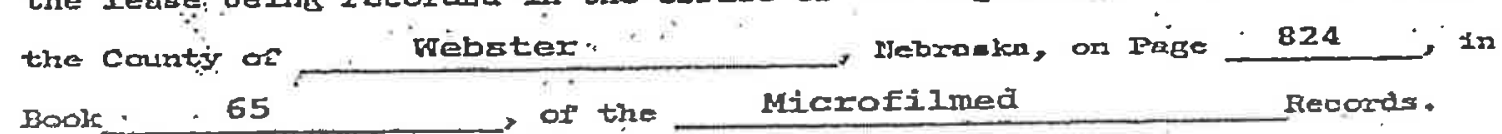
NON, THERGFCORE, Les8 ax and CCC a hereby agree as follows:

(I) That the lease bhall bo arda game lo hereby cancelled and termi-

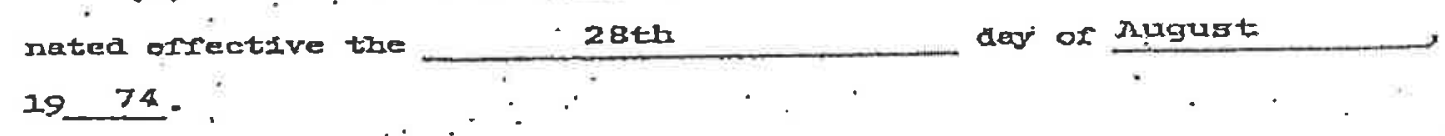

(2) That Lessor hereby walven and releases CCC fran any further obligation to restion the prenises to the same condition as that esistirio at the time that cec first enterad upon the preirises under the lease or under any prsor Inase. 
(3) That Iessor shall retain all rent previousiy paia by cco, and that Ireaor horeby releases CCC of all furthex obligation to make rant payments.

(4) Tripe termination is executed on behalf of CCC prirevant to delogation of authority prabsahed in tho Federal Reglatex (26 F.R. 3900 ).

CORAODIIY CREDIT CORFORATIOIT
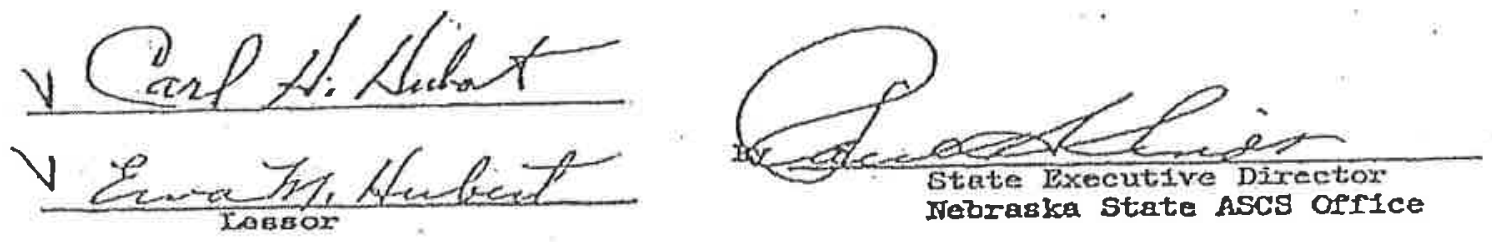

\section{ACKCFOWLETDCMEANT}

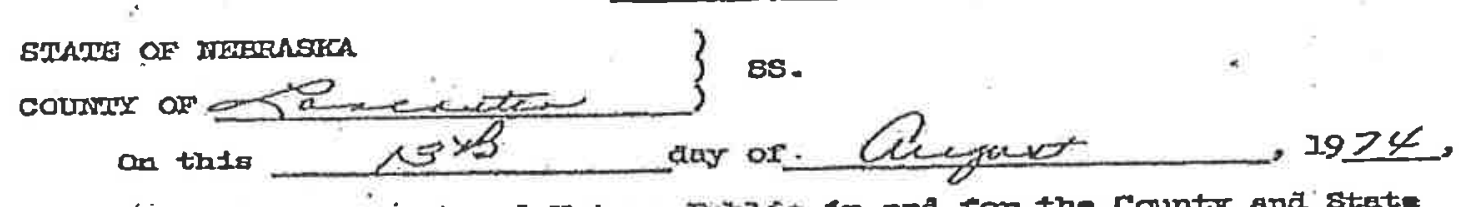
befoxe mo, the undiraloned Notary Eublige in and Ior tho Counts and state aforeviaid, personaliy appoured

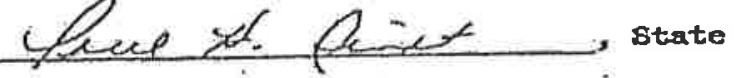
Executive Diractor, Agricultural stabilixation and Canservation Service, Unitad Stated Depertament of Abriculture, who is peraonelly lonown to me and persopally known to be auch state Exacutive Director, and the seme parson who exceuted the wlthin ard loregolse Instrument, and he duly ackowledged the execution of the wero ICr and on behoze of and as the tree act and deed of: Commodity crealt corporation: 
+ foage cose

$-3-$

IN WIINESS WHFREOF, I have hereunto set wy hand and affixed my offledal seal the day and jear above written.
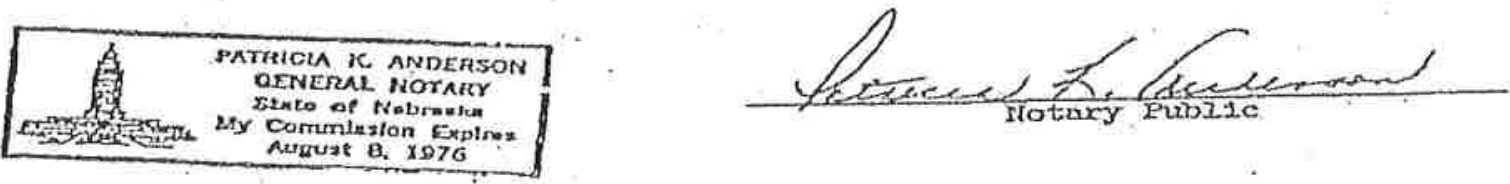

Iy comolibion explees

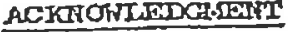

STATE OF LERBRASKA

COUNTYY OF.

webster $\}$ ss.

BE ITS REAMATHERED, that on this

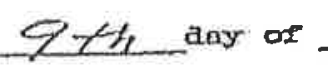

A. D.: igony, boroxe me, the umate the Cotontify ana Btato nforesuita; came

CarI H., Hubert and 'sxva M. Hubert

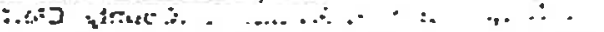

who $\therefore$ are porsonalyy. known, to 2ae to be the same person described in, and

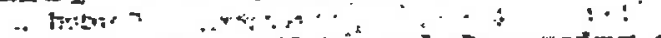

who executed the rithiti and Ioregoling egreement, and duly achnowledged

the excout lan iof the iame to be theiproluntary act and aeed.

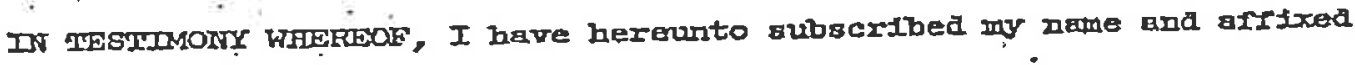
ung officfal geni; on the day. and year last above rritten.

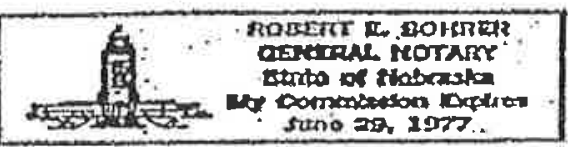

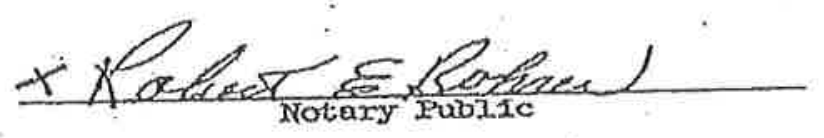

My comisizion axises

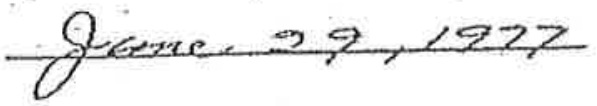




\section{page 457}

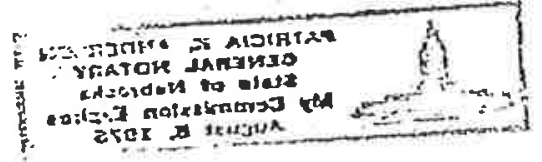

Stale of Nobrastra)

County of Wobit..r) ss. Einterat on the

numorleal index -.- I filicd for record in sha

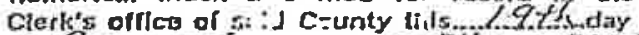

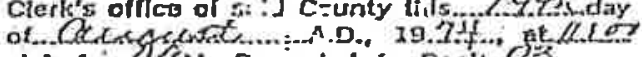

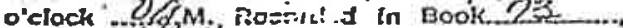

on Egen, (e.v)

ind. 5..Comp. 2 Assessar Dopury

$12.25-c h j$ ancti

Rese ceuncié

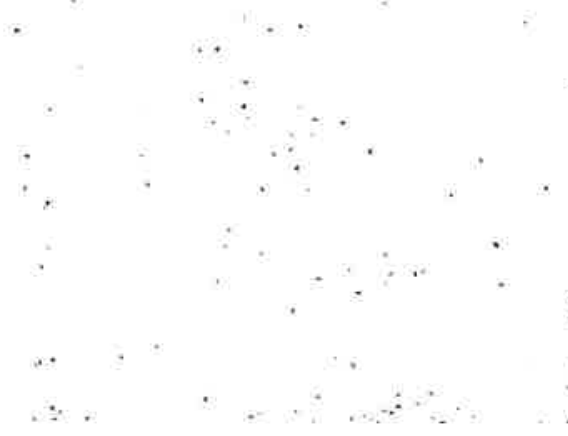

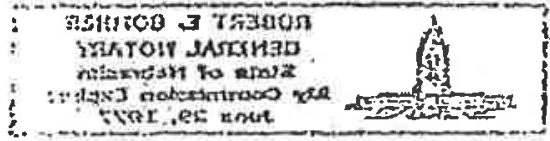


Argonne

Environmental Science Division

Argonne National Laboratory

9700 South Cass Avenue, BIdg. 203

Argonne, IL 60439-4843

www.anl.gov 